US Army Corps

of Engineers:

Prepared for the U.S. Army Corps of Engineers, Portland District,

under an Interagency Agreement with the U.S. Department of Energy

Contract DE-AC05-76RL01830

\title{
Characterization of Fish Passage Conditions through the Fish Weir and Turbine Unit 1 at Foster Dam, Oregon, Using Sensor Fish, 2012
}

\section{Final Report}

\author{
JP Duncan
}

February 2013

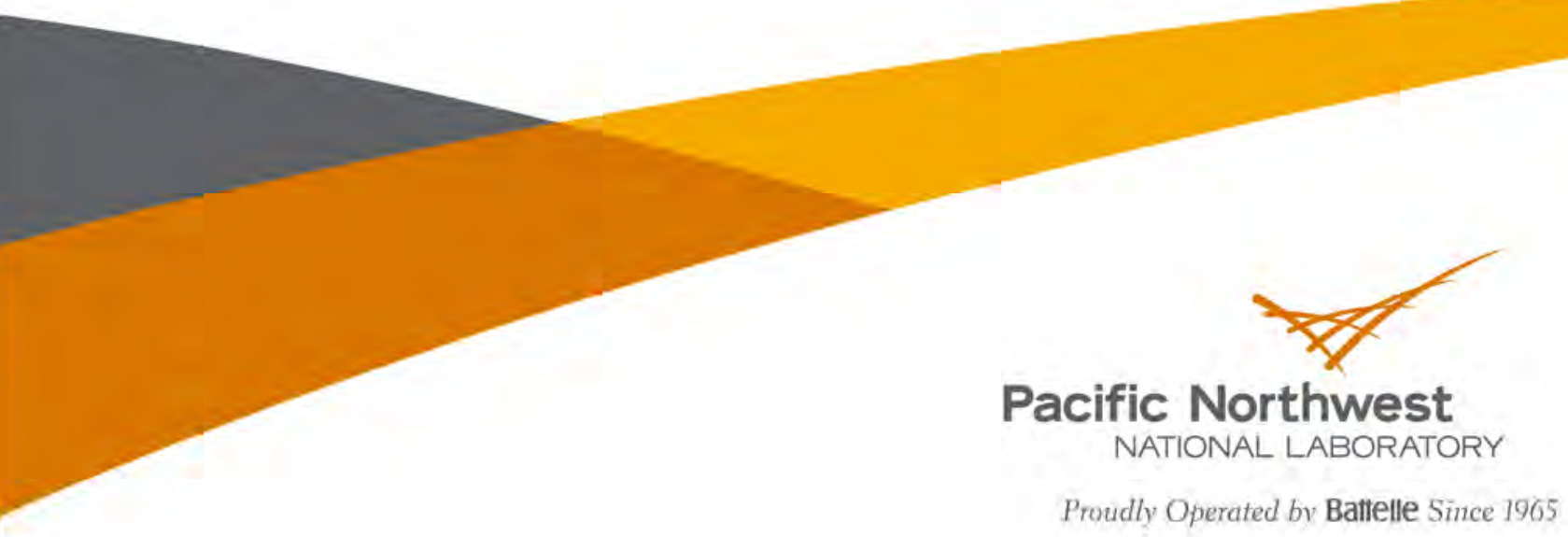




\section{DISCIAIMER}

This report was prepared as an account of work sponsored by an agency of the United States Government. Neither the United States Government nor any agency thereof, nor Battelle Memorial Institute, nor any of their employees, makes any warranty, express or implied, or assumes any legal liability or responsibility for the accuracy, completeness, or usefulness of any information, apparatus, product, or process disclosed, or represents that its use would not infringe privately owned rights. Reference herein to any specific commercial product, process, or service by trade name, trademark, manufacturer, or otherwise does not necessarily constitute or imply its endorsement, recommendation, or favoring by the United States Government or any agency thereof, or Battelle Memorial Institute. The views and opinions of authors expressed herein do not necessarily state or rellect those of the United States Government or any agency thereor.

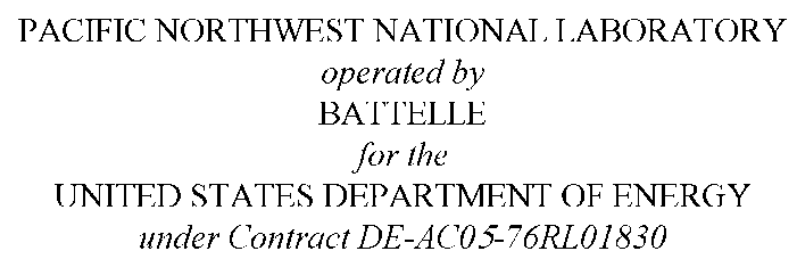

Printed in the United States of America

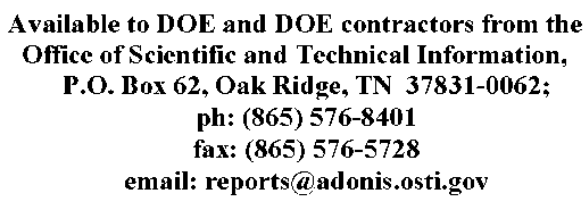

Available to the public from the National Technical Information Service, U.S. Department of Commerce, 5285 Port Royal Rd., Springfield, VA 22161 ph: (800) 553-6847 fax: (703) 605-6900

email: orders(a)ntis.fedworld_gov

online ordering: http://www.ntis.gov/ordering.htm

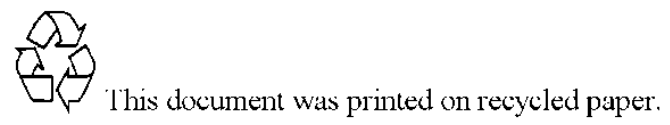

$(9 / 2003)$ 


\section{Characterization of Fish Passage Conditions through the Fish Weir and Turbine Unit 1 at Foster Dam, Oregon, Using Sensor Fish, 2012}

\section{Final Report}

JP Duncan

February 2013

Prepared for

the U.S. Army Corps of Engineers, Portland District, under an Interagency Agreement with the U.S. Department of Energy

Contract DE-AC05-76RL01830

Pacific Northwest National Laboratory

Richland, Washington 99352 


\section{Summary}

Fish passage conditions through a Kaplan turbine and spillway fish weir at Foster Dam, located on the South Santiam River in Linn County, Oregon, were evaluated by Pacific Northwest National Laboratory for the U.S. Army Corps of Engineers, Portland District, using Sensor Fish devices. The objective of the study was to describe and compare passage exposure conditions, identifying potential fish injury regions encountered during passage via specific routes. The investigation was performed in May 2012, concurrent with HI-Z balloon-tag studies by Normandeau Associates, Inc.

Sensor Fish data were analyzed to characterize the passage exposure conditions through the spillway fish weir and turbine Unit 1 at Foster Dam at two forebay pool elevations (616 and $634 \mathrm{ft}$ mean sea level [MSL]) and to estimate data relationships with live fish injury and mortality estimates.

For the spillway fish weir evaluation, Sensor Fish and live fish were deployed through injection system piping mounted on the weir. The bottom of the injection pipe was at an elevation of approximately $614 \mathrm{ft}$ during testing at the 616 - $\mathrm{ft}$ MSL (low) forebay elevation and at $632 \mathrm{ft}$ during the 634-ft MSL (high) forebay level tests. Two systems were used-a 4-in. pipe for juvenile fish releases and an 8-in. pipe for adult releases at each elevation.

Low discharge flows over the fish weir at Foster Dam resulted in a shallow depth of flow and a poorly formed discharge jet. As a result, the Sensor Fish came into contact with the spillway surface multiple times during passage, from initial impact to the bottom of the spillway chute. In addition, the slope of the spillway chute, at approximately 25 degrees, and the discharge jet's angle of impact contributed to conditions that could be deleterious to fish passing via this route.

All Sensor Fish passing over the spillway weir experienced significant events, as determined from acceleration magnitude data $(n=42)$. A significant event is defined as an impulse in acceleration magnitude greater than or equal to $95 \mathrm{~g}$. Significant events are caused by strike, collision with dam structure, or exposure to shear. Shear events were observed during the high-forebay treatment (634 ft MSL), and all occurred at chute impact. All other significant events were collisions, regardless of treatment condition. Event severity was greatest for Sensor Fish passing over the weir at the low-forebay level through the juvenile fish pipe, with a mean value of $157.6 \mathrm{~g}$. However, $23 \%$ of the Sensor Fish passing over the weir at the high-forebay level were damaged following passage through the juvenile fish pipe compared with $5 \%$ at the low-forebay level.

The nearly vertical drop after exiting the injection pipe and the fact that some of the Sensor Fish and steelhead were not entrained in the flow prior to passage over the spillway weir likely contributed to injuries - especially at the high-forebay level, where the drop was over $40 \mathrm{ft}$. Sensor Fish weighing approximately 50 grams with their attached balloons and radio tag would have an impact force of 1,865 and 3,185 newtons (N) for the low- and high-forebay levels, respectively. Adult steelhead may experience forces of as much as 260,540 N, resulting in injury or mortality, depending on the surface area over which the force was distributed.

For the turbine evaluation, Sensor Fish were injected into the turbine intake flow at an elevation of approximately $593 \mathrm{ft} \mathrm{MSL}$, slightly higher than the penstock centerline elevation (590 ft MSL). Exit from the pipe terminus occurred into flows of approximately $5 \mathrm{fps}$, providing guidance into the penstock. 
Four turbine operation levels were tested at the low-forebay level, ranging from 2.8 to $7.0 \mathrm{MW}$, and three operation levels were tested at the high-forebay level, ranging from 4.9 to 9.0 MW.

Sensor Fish experienced high damage/loss rates of more than 22\% during turbine passage. Evidence of grinding or squeezing was evident in several Sensor Fish units, assumed to be from being compressed between the turbine blade and wall. Sixty-two percent of the Sensor Fish experienced at least one significant event during turbine passage $(n=50)$. For the low-forebay turbine operations, events were most frequent at the wicket gates; for the high-forebay operations, events were more prevalent during runner passage. Events observed at the wicket gates at high-forebay operations were generally of a lower magnitude than those detected at the low-forebay operations.

The significant event magnitude values for the most severe event experienced by Sensor Fish during passage through turbine Unit 1 were greatest at the low-forebay 4.9/5.0-MW operation, averaging $152.8 \mathrm{~g}$. Highest severe event magnitude at the high-forebay level was $142.8 \mathrm{~g}$, at the 6.5-MW operation. Significant events of the greatest magnitudes were generally higher during the low-forebay treatment than during high-forebay treatment. The occurrence of more than one significant event during the passage of an individual Sensor Fish was more likely during high-forebay operations.

Significant event occurrences as experienced by the Sensor Fish were two to three times more frequent for Foster Dam turbine passage than those observed during previously conducted studies of Kaplan turbine passage at Columbia River dams. Contributing factors to the higher number of events at Foster Dam may include the following: the turbine runners are smaller in diameter, have six blades, and rotate at $257 \mathrm{rpm}$, and the associated velocity at the periphery of the runner is approximately $224 \mathrm{fps}$. A simulation model was used to estimate the possibility of fish being injured by a strike with the runner blade. The strike probability estimates made using a blade strike model compared favorably with the frequency of occurrence of severe events observed using Sensor Fish. In addition, the blade strike model estimates of injury probability tracked the observed frequency of occurrence of injury to live balloontagged test fish.

Lowest pressure nadirs observed during turbine passage were for the high-head (high-forebay) operations. The observed nadir values for the Foster Dam turbine are comparable to those observed for Kaplan turbines installed in the mainstem Columbia and Snake river dams, ranging from approximately 14 to 21 psia.

Comparison of Sensor Fish results for the two passage routes tested at Foster Dam during spring 2012 indicate that Sensor Fish passing over the spillway weir experienced higher event magnitudes than those passing through the turbine because most experienced significant events upon impact with the spillway chute. Increasing the depth of flow would likely enhance passage conditions by providing an improved discharge jet as well as a cushioning effect for fish and Sensor Fish. Possible changes to the weir design should also be investigated to improve the route's safety at both pool levels. 


\section{Acronyms and Abbreviations}

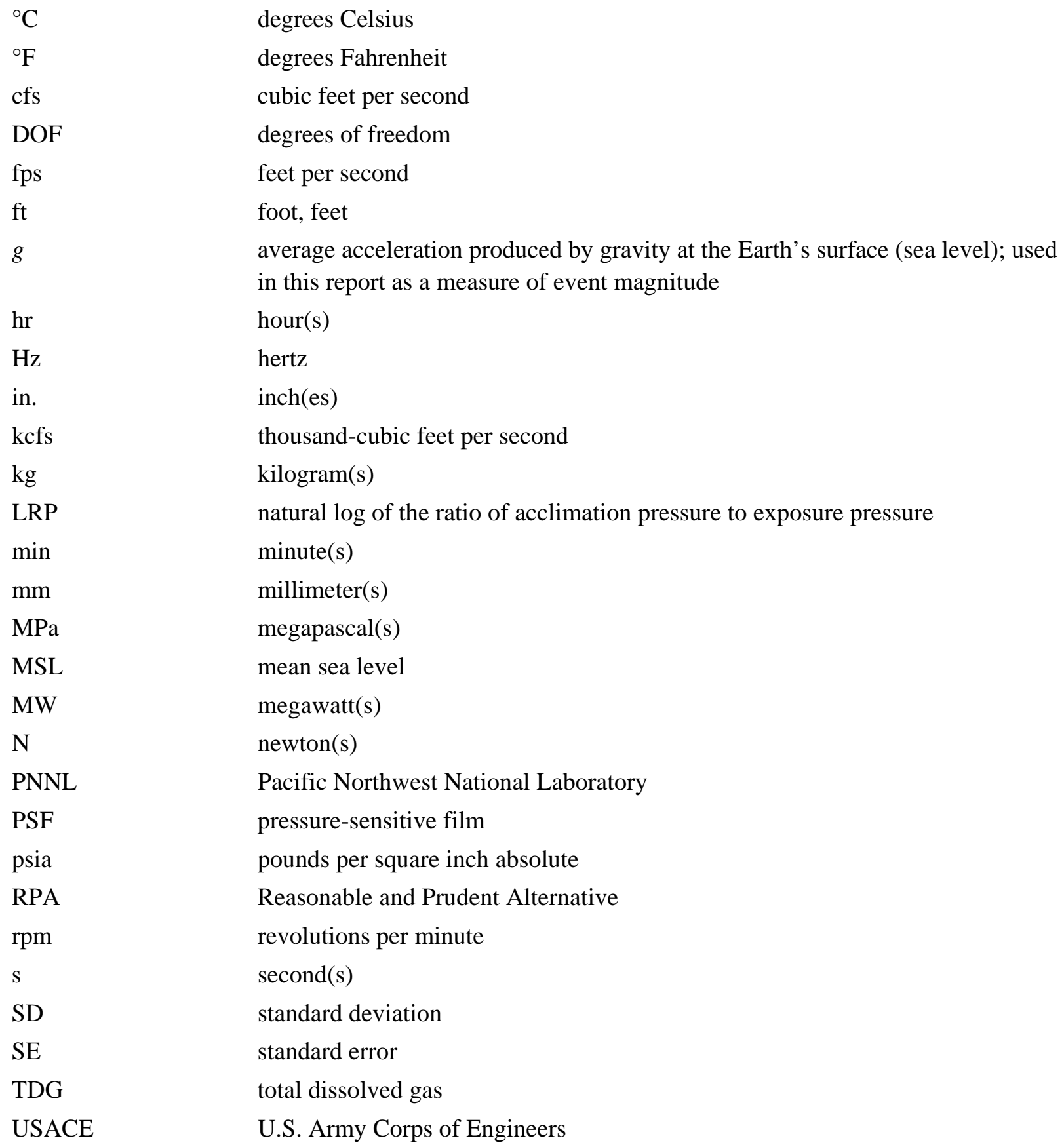

TDG

degrees Celsius

degrees Fahrenheit

cubic feet per second

degrees of freedom

feet per second

foot, feet

average acceleration produced by gravity at the Earth's surface (sea level); used in this report as a measure of event magnitude

hour(s)

hertz

inch(es)

thousand-cubic feet per second

kilogram(s)

natural log of the ratio of acclimation pressure to exposure pressure

minute(s)

millimeter(s)

megapascal(s)

mean sea level

megawatt(s)

newton(s)

Pacific Northwest National Laboratory

pressure-sensitive film

pounds per square inch absolute

Reasonable and Prudent Alternative

revolutions per minute

second(s)

standard deviation

standard error

total dissolved gas

U.S. Army Corps of Engineers 


\section{Contents}

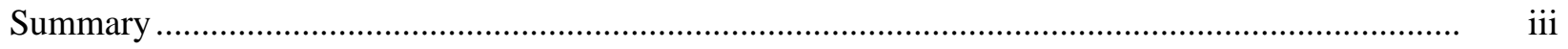





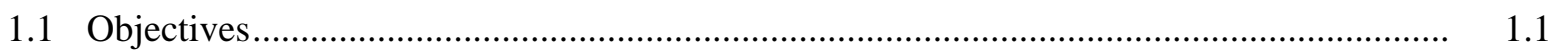

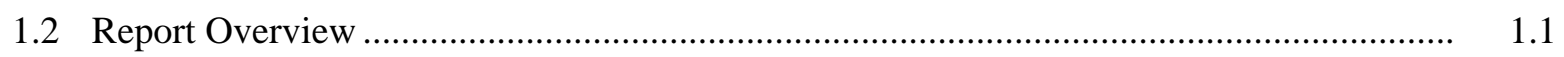

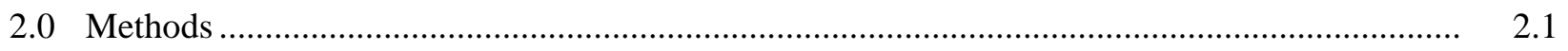



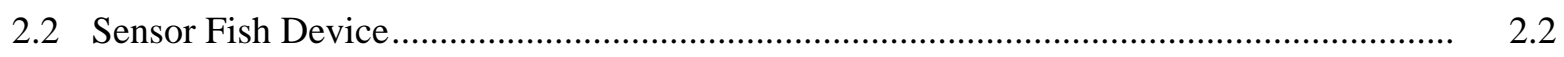

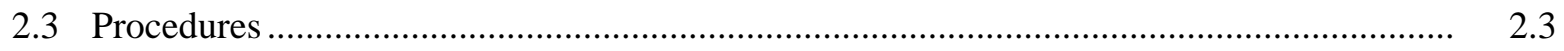

2.3.1 Spillway Fish Weir Evaluation.......................................................................... 2.3

2.3.2 Turbine Passage Evaluation …..................................................................... 2.4

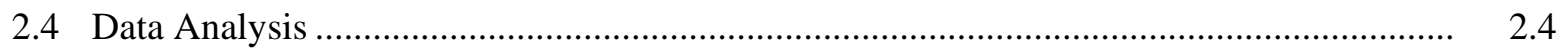

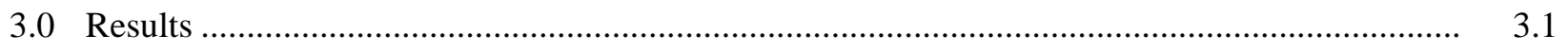

3.1 Treatment Release Data .................................................................................. $\quad 3.1$

3.1.1 Spillway Fish Weir Evaluation....................................................................

3.1.2 Turbine Evaluation .......................................................................................... 3.1

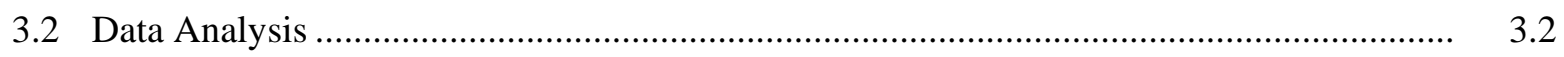

3.2.1 Spillway Fish Weir Passage …...................................................................... 3.2

3.2.2 Penstock/Turbine Passage ................................................................................... 3.3

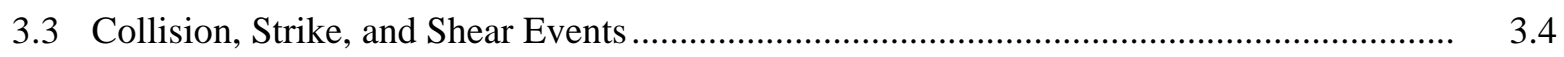

3.3.1 Spillway Fish Weir Passage .......................................................................... 3.5

3.3.2 Turbine Passage ................................................................................................ 3.9

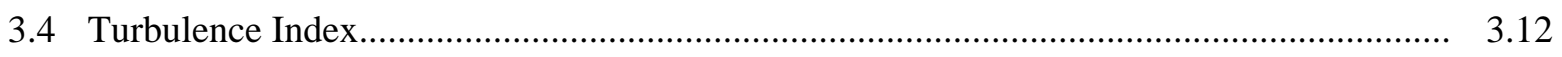

3.5 Comparison of Sensor Fish and Live-Fish Data ........................................................... 3.13



4.1 Spillway Fish Weir Passage ....................................................................................... 4.1

4.2 Penstock/Turbine Passage ......................................................................................... 4.6

5.0 Conclusions …......................................................................................................... 5.1

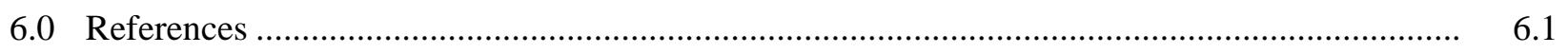

Appendix A - Field Log Data Sheets ............................................................................... A.1

Appendix B - Data Summary Tables for Each Sensor Fish Release .............................................. B.1

Appendix C - Pressure and Acceleration Magnitude Time Histories for Each Sensor Fish

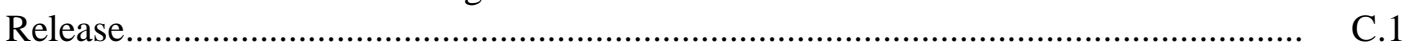

Appendix D - Pressure and Angular Rate-of-Change Time Histories of Each Sensor Fish

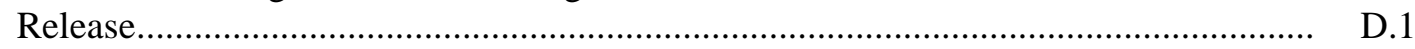




\section{Figures}



$2.2 \quad$ Foster Dam spillway ................................................................................................. 2.2

2.3 Six-degree-of-freedom Sensor Fish device ...................................................................... 2.2

2.4 Approximate height of the spillway fish weir above the spillway crest for the high forebay level and low forebay level

3.1 Representative Sensor Fish data overlaid on a cross section of the Foster Dam spillway weir showing the approximate locations of selected major timing marks

3.2 Representative Sensor Fish data overlaid on a cross section of the Foster Dam turbine region showing the approximate locations of selected major timing marks ...

3.3 Location of all Sensor Fish significant events by region following spillway weir passage

3.4 Sensor Fish significant event occurrence by type following spillway weir passage......

3.5 Mean acceleration magnitude location for the most severe significant events experienced by Sensor Fish during spillway fish weir passage

3.6 Mean acceleration magnitude location for all significant events experienced by Sensor Fish during spillway fish weir passage

3.7 Sensor Fish event magnitudes for the most severe event and cumulative events by turbine operation

3.8 Nadir pressures observed during passage through Foster Dam turbine Unit 1 as measured by Sensor Fish.

3.9 Average pressure rate of change through Foster Dam turbine Unit 1

3.10 Live-fish mortality and malady estimates contrasted with Sensor Fish significant event magnitudes for passage over the spillway fish weir.

3.11 Live-fish mortality and malady estimates contrasted with Sensor Fish significant event magnitudes through turbine Unit 1

3.12 Live-fish mortality and malady estimates contrasted with the Sensor Fish turbulence index for passage through turbine Unit 1 .....

3.13 Live-fish mortality and malady estimates contrasted with the Sensor Fish pressure rate of change during passage through turbine Unit 1

4.1 Spillway weir flow impacts the concrete chute prior to flowing into the stilling basin.

4.2 Spill over the weir at John Day Dam with Sensor Fish data superimposed.

4.3 Comparison of spillways at John Day Dam and Foster Dam

4.4 Fish injection system pipe attachment at Foster Dam and juvenile and adult steelhead being propelled out of the system during testing

4.5 Flow over the spillway fish weir at Foster Dam during the high-forebay condition

4.6 Sensor Fish in pieces following passage at the 9.0-MW, high-forebay condition

4.7 Data from cracked Sensor Fish stops at the runner

4.8 A stress crack in the Sensor Fish polycarbonate body following passage through turbine Unit 1

4.9 Probability of mortal injury from simulated turbine passage. 
4.10 Fit of a linear model between live-fish estimated 48-hr mortality and the percentage of Sensor Fish experiencing a significant event at Columbia and Snake River dams and Foster Dam

4.11 Turbine runner passage pressure rate of change by nadir pressure for Foster, John Day, Bonneville, and Ice Harbor dams.

\section{Tables}

2.1 Turbine operation levels tested at Foster Dam in 2012

3.1 Number of Sensor Fish releases by study treatment during the May 2012 fish weir evaluation.

3.2 Number of Sensor Fish releases by study treatment during the May 2012 turbine evaluation at Foster Dam

3.3 Location, frequency, and type of the most severe significant event observed for Sensor Fish releases over the spillway weir

3.4 Frequency of occurrence of all Sensor Fish significant events by event location and type for Sensor Fish releases over the spillway weir....

3.5 Sensor Fish turbine releases showing type of most severe significant event observed

3.6 Sensor Fish frequency of occurrence of multiple turbine runner events by type

3.7 Computed area under the curve for angular rate-of-change and acceleration magnitudes per second

3.8 Mortality and malady rates of steelhead released over the spillway fish weir at Foster Dam compared with hydraulic information obtained by Sensor Fish, May 2012

3.9 Mortality and malady rates of steelhead released through Unit 1 turbine at Foster Dam compared with hydraulic information obtained by Sensor Fish, May 2012 .....

4.1 Sensor Fish nadir pressures; estimated depth acclimation pressures at approach and passage, ratio of acclimation to nadir, and natural log of the ratio for passage through turbine Unit 1 at Foster Dam, 2012.

4.2 Average live-fish mortality and percentage of Sensor Fish experiencing a significant event during Kaplan turbine passage at USACE hydropower projects.

4.3 Pressure nadirs observed in Sensor Fish data during turbine passage at USACE hydropower projects.

4.4 Pressure rates of change observed from Sensor Fish turbine passage at USACE hydropower projects.

4.5 Probability of strike and injury for fish passing through Foster Dam turbine Unit 1 


\subsection{Introduction}

The Willamette River and its tributaries provide essential habitat for salmon and trout species. The development of hydropower dams in the upper basin tributaries has impacted conditions throughout the river system, altering the stream ecology and fish survival.

This evaluation provides information to the U.S. Army Corps of Engineers (USACE), Bonneville Power Administration, and the U.S. Department of Reclamation (the Willamette Valley project action agencies) that can be used to implement Reasonable and Prudent Alternatives (RPAs) 4.3 "Willamette Fish Operations Plan,” 4.8 "Interim Downstream Fish Passage,” 4.11 "Assess downstream juvenile fish passage through dams," 4.13 "Willamette configuration and operations plan," and 9.3 "Fish passage RM\&E” under the National Marine Fisheries Service 2008 Biological Opinion. RPAs are measures designed to minimize adverse effects of dams, reservoirs, and other reservoir projects on Endangered Species Act-listed species and their critical habitat. Monitoring and reporting are required as part of the Biological Opinion to ensure compliance.

This report documents investigations of downstream fish passage research involving a spillway fish weir and turbine passage conditions at Foster Dam in May 2012. The studies were conducted by Pacific Northwest National Laboratory (PNNL) for the U.S. Army Corps of Engineers (USACE), Portland District, and performed concurrently with HI-Z balloon-tag studies of passage survival for juvenile and adult steelhead conducted by Normandeau Associates, Inc. (Normandeau).

\subsection{Objectives}

The objectives of this study were to

- Characterize the passage exposure conditions through the spillway fish weir at Foster Dam at two forebay pool elevations (616 and $634 \mathrm{ft}$ mean sea level [MSL]).

- Describe and compare the passage exposure conditions through a turbine unit at Foster Dam under three operations at two pool elevations (616 ft MSL and $634 \mathrm{ft} \mathrm{MSL).}$

- Collaborate with Normandeau staff on a Sensor Fish and live test fish comparison for the study.

\subsection{Report Overview}

Chapter 2 describes the study site, the Sensor Fish device, and the data collection and analysis procedures used in the research. Chapter 3 presents the results of the study, followed by a discussion in Chapter 4. Conclusions are offered in Chapter 5, followed by Chapter 6, the sources cited in this report.

The compact disc included in the pocket on the inside back cover of printed copies of this report contains supplementary details and data in four appendices. Appendix A contains field log data that provide dam operating conditions, release elevations, and deployment and recovery times for each Sensor Fish release. Appendix B provides summary data tables for each Sensor Fish release. Dam operating conditions, exposure event descriptions, pressures at injection, and rates of change in pressure are included in the data tables. Appendices $\mathrm{C}$ and $\mathrm{D}$ present graphics showing pressure, acceleration magnitude, and change of magnitude time histories for each Sensor Fish release. 


\subsection{Methods}

\subsection{Study Site}

Foster Dam is located at river mile 38.5 on the South Santiam River in Linn County, Oregon (Figure 2.1). It is a storage dam used for flood control, power generation, irrigation, navigation, and recreation. The dam, a rock-fill embankment approximately $126 \mathrm{ft}$ tall and 4,600 ft long, has four radial tainter spillway gates and a powerhouse containing two Kaplan turbine units. The turbines have a hydraulic capacity of 3,200 cubic feet per second (cfs) and a total capacity of 20 megawatts (MW). Full pool is $641.0 \mathrm{ft}$ MSL; minimum pool is $613.0 \mathrm{ft}$ MSL.

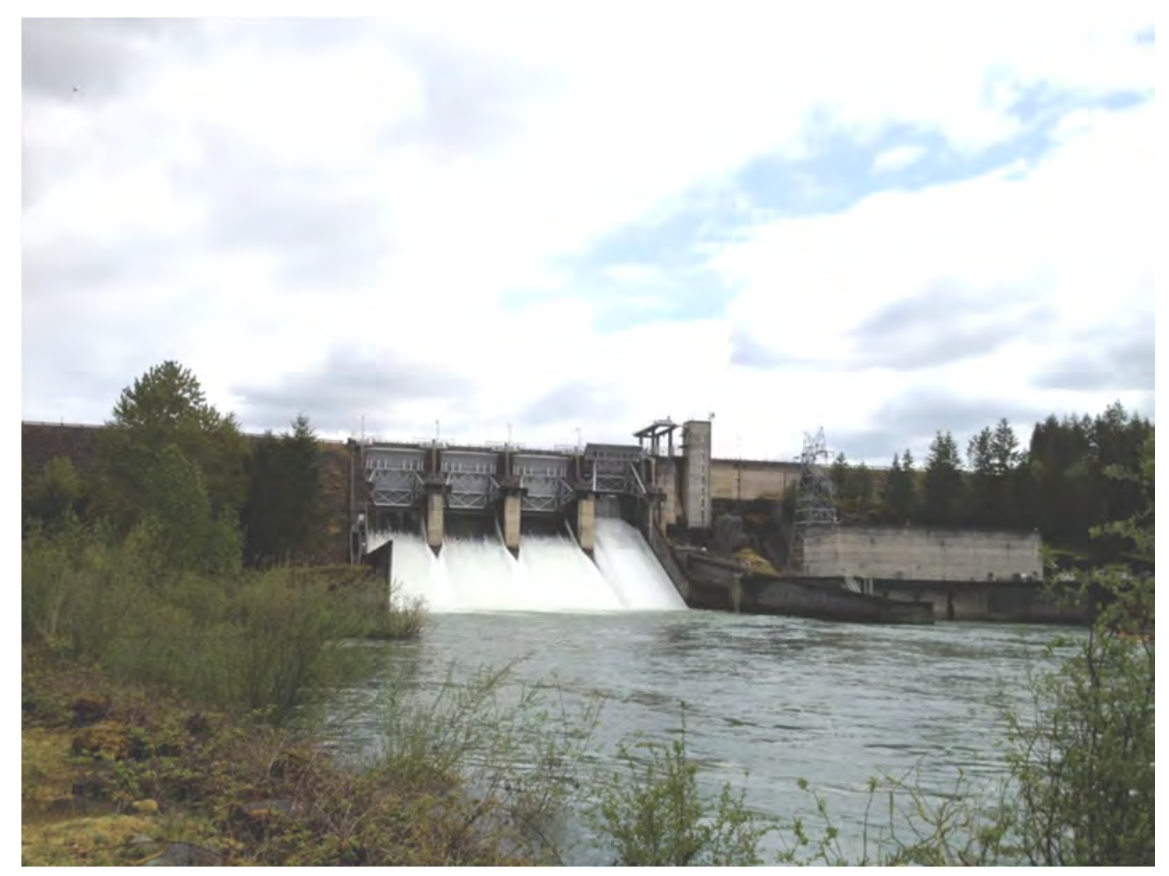

Figure 2.1. Foster Dam, Oregon.

There are separate intakes for each of the turbine units; each has a 13.5-ft-diameter penstock located at a centerline elevation of $590 \mathrm{ft}$ MSL, progressing approximately $215 \mathrm{ft}$ to its terminus at a centerline elevation of $516 \mathrm{ft}$ MSL. Each Allis-Chalmers Kaplan turbine is a 13,800-horsepower unit, operating at 257 revolutions per minute (rpm) with a maximum discharge of approximately 1,350 cfs. The runner diameter is approximately 100 in., and runner opening height is 42.5 in.; velocity at the periphery of the runner is approximately 224 feet per second (fps). Each turbine unit has 6 blades and 20 wicket gates.

The spillway crest is at elevation $596.8 \mathrm{ft}$ MSL (Figure 2.2). 


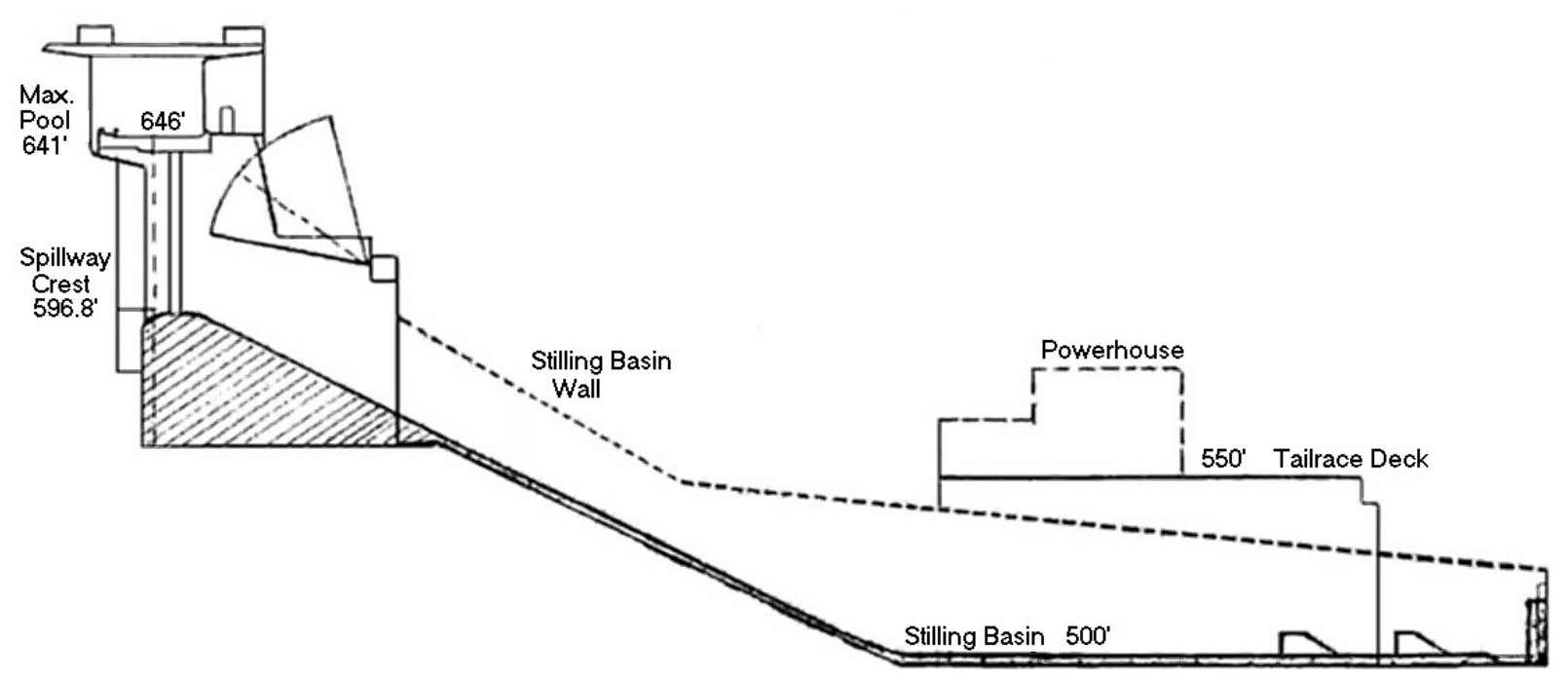

Figure 2.2. Foster Dam spillway.

\subsection{Sensor Fish Device}

The Sensor Fish housing is constructed of clear polycarbonate plastic (Figure 2.3). It is $24.5 \mathrm{~mm}$ in diameter and $90 \mathrm{~mm}$ long and weighs approximately 43 grams. The Sensor Fish is nearly neutrally buoyant in fresh water. The device measures the three components of linear acceleration, the three components of angular velocity (these together comprise the six degrees of freedom [DOF]), absolute pressure, and temperature, at a sampling frequency of 2,000 $\mathrm{Hz}$ per sensor channel over a recording time of about $4 \mathrm{~min}$.

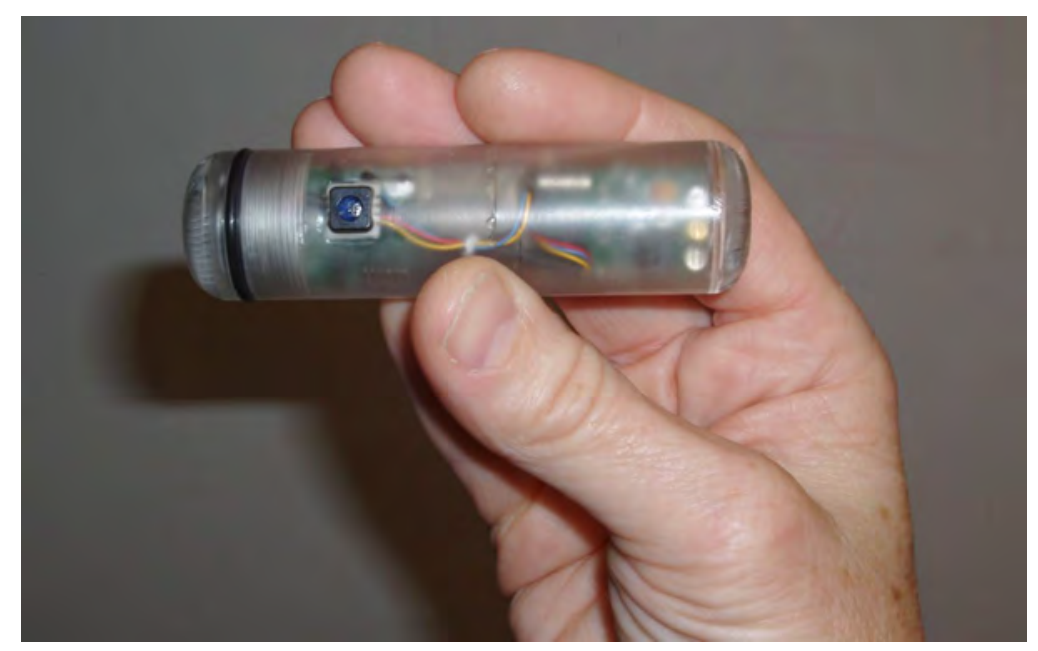

Figure 2.3. Six-degree-of-freedom Sensor Fish device.

The Sensor Fish consists of modules that charge its internal battery, program the sensor settings, acquire data, and convert from analog signal to digital form. The acquired data are stored in an internal memory card and transferred to computers via a wireless infrared link using an external infrared link 
modem. Sensor Fish are deployed, acquiring data in response to hydraulic conditions and interaction with structure; units are retrieved; and the data are downloaded, analyzed, and interpreted.

Retrieval of the Sensor Fish is aided by the attachment of a micro-radio transmitter (Advanced Telemetry Systems, Isanti, Minnesota) and HI-Z balloon tags (Normandeau Associates, Inc., Bedford, New Hampshire), which are identical to those used for live test fish (Heisey et al. 1992). HI-Z tags contain a water-soluble capsule filled with a chemical that produces gas when activated with water, a process that takes approximately 3 min following initiation. The balloons inflate sufficiently to bring the Sensor Fish to the surface for recovery, and a directional radio receiver antenna used by boaters in the tailrace homes in on the radio transmitter attached to the Sensor Fish.

\subsection{Procedures}

Sensor Fish releases were interspersed with releases of HI-Z balloon-tagged live fish through the same release pipes in concurrent studies conducted by Normandeau Associates. Study plans called for 1 Sensor Fish release for every 10 live juvenile fish treatment releases, when feasible.

\subsubsection{Spillway Fish Weir Evaluation}

The spillway fish weir tests were conducted at two forebay elevations: $616 \mathrm{ft}$ MSL, just above minimum pool, and $634 \mathrm{ft}$ MSL. Sensor Fish releases corresponding to juvenile live fish releases were made through an induction system consisting of a large-diameter (4-in.) flexible hose attachment connected to a frame that was placed above the fish weir. Adult fish releases were through an 8-in. flexible hose. The terminus of each pipe system was at an elevation approximately $1 \mathrm{ft}$ above the top of the weir, or $614 \mathrm{ft}$ and $632 \mathrm{ft}$ MSL for forebay elevations of $616 \mathrm{ft}$ MSL and $634 \mathrm{ft}$ MSL, respectively. Pipe terminuses were approximately $18 \mathrm{ft}$ and $36 \mathrm{ft}$, respectively, above the spillway crest elevation (Figure 2.4).

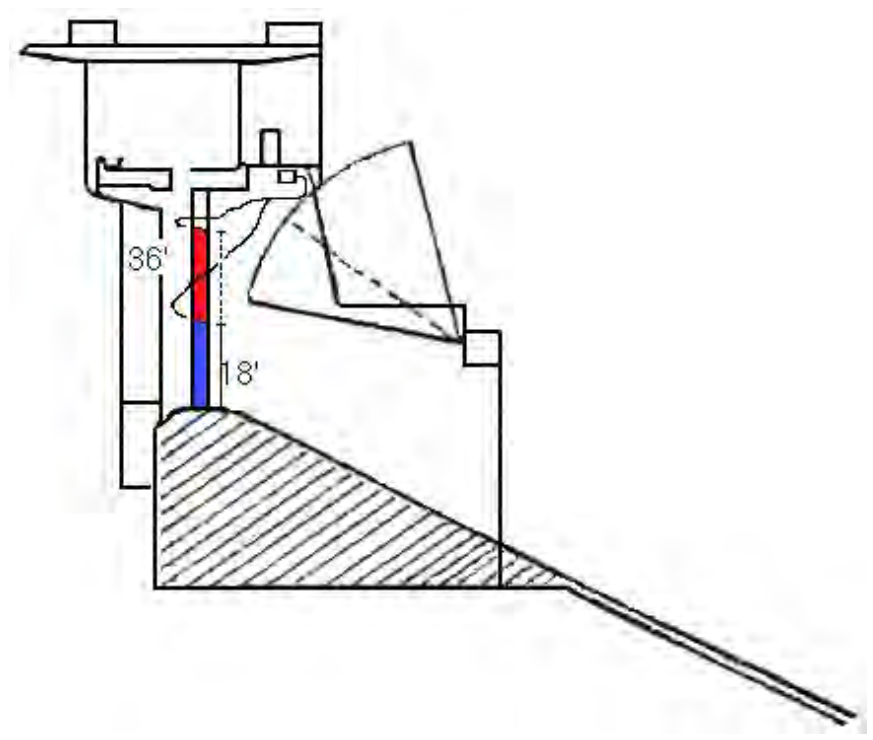

Figure 2.4. Approximate height of the spillway fish weir above the spillway crest for the high forebay level (red) and low forebay level (blue). 


\subsubsection{Turbine Passage Evaluation}

Four turbine operations at turbine Unit 1 were tested at the low-forebay elevation and three operations were tested at the high-forebay elevation (Table 2.1). Sensor Fish releases were made through an induction system similar to that used for the spillway fish weir passage evaluation. Flexible hosing (4 in. in diameter) connected the head of a steel pipe to the juncture of the modified head tank where live fish and Sensor Fish were introduced into the induction system. The frame was attached to the penstock bulkhead slot, and the terminus of the pipe system was at an elevation of approximately $593 \mathrm{ft}$ MSL, slightly higher than the penstock centerline elevation (590 ft MSL). Exit from the pipe terminus occurred into flows of approximately $5 \mathrm{fps}$, providing guidance into the penstock.

Table 2.1. Turbine operation levels tested at Foster Dam in 2012.

\begin{tabular}{ccc}
\hline $\begin{array}{c}\text { Forebay } \\
\begin{array}{c}\text { Elevation } \\
\text { (ft MSL) }\end{array}\end{array}$ & $\begin{array}{c}\text { Unit Output } \\
\text { (MW) }\end{array}$ & $\begin{array}{c}\text { Flow } \\
\text { (cfs) }\end{array}$ \\
\hline & $2.8 / 3.0$ & 550 \\
616 & $4.9 / 5.0$ & 800 \\
& 6.0 & 970 \\
& 7.0 & 1150 \\
634 & $4.9 / 5.0$ & 650 \\
& 6.5 & 820 \\
& 9.0 & 1150 \\
\hline
\end{tabular}

\subsection{Data Analysis}

Sensor Fish data sets consist of time histories of angular motion (pitch, roll, and yaw), pressure, acceleration ( $x, y$, and $z$ axes), temperature, and battery status extending from the time of release through the period of data acquisition programmed into the Sensor Fish (Deng et al. 2007a). Data time histories contain a data point for each transducer every $0.0005 \mathrm{~s}$. This time interval between digital samples corresponds to a 2,000-Hz sampling rate for each of the analog outputs from Sensor Fish acceleration, rotation, and pressure sensors. Sampling of all analog data streams occurs nearly simultaneously within each sampling interval.

Water depth in feet is estimated, when appropriate, from absolute pressure at various points along each Sensor Fish route by subtracting atmospheric pressure, determined at the time of the release of each Sensor Fish, and dividing the resulting gage pressure by 0.4335 , the pressure in pounds per square inch of 12 in. of fresh (distilled) water at $39.2^{\circ} \mathrm{F}\left(4^{\circ} \mathrm{C}\right)$. The raw output of the triaxial accelerometers is processed to detect and quantify Sensor Fish response to turbulence, contact with structure (strike or collision), and shear. Triaxial angle rate-of-change data are processed similarly to triaxial acceleration data to provide further information about the response of the Sensor Fish to flow conditions and another measure of quality of flow.

Analysis of the raw data from the Sensor Fish begins with preparation of plots showing absolute pressure, triaxial acceleration, and triaxial rotation. These records are visually inspected to identify 
prospective collision, strike, and shear events and to obtain a general overview of the passage conditions present for each test treatment. Changes in pressure during passage include features consistently present that result from the design of passageway structures and the dynamics of water flow through the passageway. These features in the pressure time history permit acceleration and rotation data to be divided into segments corresponding to specific locations (zones) that extend from Sensor Fish injection to exit from the stilling basin. Each region is identified by characteristic features in the Sensor Fish pressure time history and characteristics in triaxial acceleration and rotation data. For each Sensor Fish data set, events of interest, such as rapid pressure changes, collisions, strikes, shear, and severe turbulence, are identified and quantified. Quantification of events includes the time of occurrence, location by zone, and extraction of information describing severity as well as additional information to separate collisions and strikes from shear exposure. 


\subsection{Results}

Detailed data on which this chapter is based are provided in the appendices. Appendix A contains study data that include the release and recovery times for each Sensor Fish, discharge and other information describing the operation of the passage route for each Sensor Fish release, and other project information for passage over the spillway fish weir and through the penstock and turbine. Appendix B contains tables of observed maximum acceleration magnitudes, pressure rates of change, and turbine pressure nadirs for Sensor Fish releases, as well as dam operations data for the respective studies. Graphs with plots of pressure and acceleration magnitude for each successful Sensor Fish release are located in Appendix C; those of pressure and angular rate-of-change magnitude are in Appendix D.

\subsection{Treatment Release Data}

Data were acquired from Sensor Fish following passage over the spillway fish weir and through turbine Unit 1 at Foster Dam. Release and recovery information for each route follows.

\subsubsection{Spillway Fish Weir Evaluation}

A total of 51 Sensor Fish were released through the spillway fish weir at Foster Dam between May 2 and 21, 2012; 43 data sets were acquired. Data from 8 Sensor Fish (15.7\%) could not be downloaded due to damage or failure during passage. A successful release requires both the recovery of the unit and successful download of acquired data; 42 releases provided complete data sets (Table 3.1). All Sensor Fish were recovered following weir passage. Twenty-three percent of the Sensor Fish passing over the weir at the high-forebay level were damaged following passage through the juvenile fish pipe; $5 \%$ were damaged following passage at the low-forebay level.

Table 3.1. Number of Sensor Fish releases by study treatment during the May 2012 fish weir evaluation.

\begin{tabular}{|c|c|c|c|c|c|c|c|}
\hline $\begin{array}{c}\text { Mean } \\
\text { Forebay } \\
\text { Elevation } \\
\text { (ft MSL) }\end{array}$ & Pipe & $\begin{array}{l}\text { Mean } \\
\text { Tailwater } \\
\text { Elevation } \\
\text { (ft MSL) }\end{array}$ & $\begin{array}{l}\text { Mean } \\
\text { Weir } \\
\text { Flow } \\
\text { (cfs) } \\
\end{array}$ & $\begin{array}{l}\text { Mean } \\
\text { Total } \\
\text { Spill } \\
\text { (cfs) } \\
\end{array}$ & $\begin{array}{c}\text { Total } \\
\text { Number } \\
\text { Released } \\
\end{array}$ & $\begin{array}{c}\text { Number of } \\
\text { Sensor Fish } \\
\text { Damaged }\end{array}$ & $\begin{array}{c}\text { Number of } \\
\text { Complete Data } \\
\text { Sets } \\
\end{array}$ \\
\hline \multirow{2}{*}{616} & Juvenile & 528.5 & 165 & 1200 & 19 & 1 & 16 \\
\hline & Adult & 528.2 & 158 & 1090 & 2 & 0 & 2 \\
\hline \multirow{4}{*}{634} & Juvenile & 525.9 & 148 & 148 & 26 & 6 & 20 \\
\hline & Adult & 525.6 & 210 & 210 & 2 & 0 & 2 \\
\hline & $\begin{array}{l}\text { Attached } \\
\text { to Adult }\end{array}$ & 525.9 & 230 & 230 & 2 & 0 & 2 \\
\hline & & & & Total & 51 & 6 & 42 \\
\hline
\end{tabular}

\subsubsection{Turbine Evaluation}

Sixty-seven Sensor Fish were released into turbine Unit 1 at Foster Dam between May 2 and 21, 2012 (Table 3.2). Four Sensor Fish were not recovered, and 11 were damaged during transit through the 
turbine. Due to the high failure/damage rate, an earlier version of Sensor Fish that measure only pressure and $x-y-z$ acceleration (3 DOF) rather than the 6-DOF model were used for data collection at the higher 634-ft MSL forebay elevation (approximately 75\% were the older-style units). These units sample the data at a lower collection rate (200 sample points vs. 2,000 sample points per second for the 6-DOF model). The data from the older units were comparable to those from the 6-DOF units; however, there is a possibility that data are truncated due to the slower sampling rate and because the nadir value and/or a significant event occurrence were not recorded.

Table 3.2. Number of Sensor Fish releases by study treatment during the May 2012 turbine evaluation at Foster Dam.

\begin{tabular}{cccccccc}
\hline $\begin{array}{c}\text { Mean } \\
\text { Forebay } \\
\begin{array}{c}\text { Elevation } \\
\text { (ft MSL) }\end{array}\end{array}$ & $\begin{array}{c}\text { Mean } \\
\text { Tailwater } \\
\text { Elevation } \\
\text { (ft MSL) }\end{array}$ & $\begin{array}{c}\text { Unit } \\
\text { Output } \\
\text { (MW) }\end{array}$ & $\begin{array}{c}\text { Mean } \\
\text { Turbine } \\
\text { Flow } \\
\text { (cfs) }\end{array}$ & $\begin{array}{c}\text { Total } \\
\text { Number } \\
\text { Released }\end{array}$ & $\begin{array}{c}\text { Number of } \\
\text { Sensor Fish } \\
\text { Damaged/Lost }\end{array}$ & $\begin{array}{c}\text { Number of } \\
\text { Complete } \\
\text { Data Sets }\end{array}$ & $\begin{array}{c}\text { Sensor } \\
\text { Fish with } \\
\text { Runner } \\
\text { Data }\end{array}$ \\
\hline \multirow{6}{*}{616} & 529.3 & $2.8 / 3.0$ & 550 & 7 & 0 & 6 & 6 \\
& 529.7 & $4.9 / 50$ & 800 & 13 & 4 & 9 & 10 \\
& 529.7 & 6.0 & 970 & 10 & 4 & 6 & 6 \\
& 530.1 & 7.0 & 1,150 & 9 & 4 & 5 & 5 \\
& 526.1 & $4.9 / 5.0$ & 650 & 8 & 0 & 8 & 8 \\
634 & 526.2 & 6.5 & 820 & 11 & 2 & 8 & 8 \\
& 526.5 & 9.0 & 1,150 & 9 & 1 & 8 & 8 \\
\hline
\end{tabular}

\subsection{Data Analysis}

Sensor Fish data analysis included computing the absolute and gage pressures and the acceleration and rotational magnitudes, then reviewing their time histories. Collision, strike, and/or shear events appear as high-amplitude impulses in acceleration magnitude time histories. To qualify as a significant event, a high-amplitude acceleration impulse must have a peak value equal to or greater than $95 \mathrm{~g}$. Significant events frequently also show concurrent high-amplitude pressure and rotation magnitude values, which aid in identifying the location of the event in time and space and in distinguishing collisions and strike events from shear events.

The location of a significant event is determined by the location of the impulse relative to distinctive consistent features observed in the pressure time histories.

\subsubsection{Spillway Fish Weir Passage}

Timing marks used to locate significant events and identify regions of spillway fish weir passage include

1. passage through the injection system piping

2. exit from the injection system pipe into the air (free fall) 
3. impact with the spillway chute

4. passage along the spillway concrete chute

5. transition into the stilling basin/tailrace.

Examples of pressure timing marks used for the spillway fish weir study are shown in Figure 3.1.

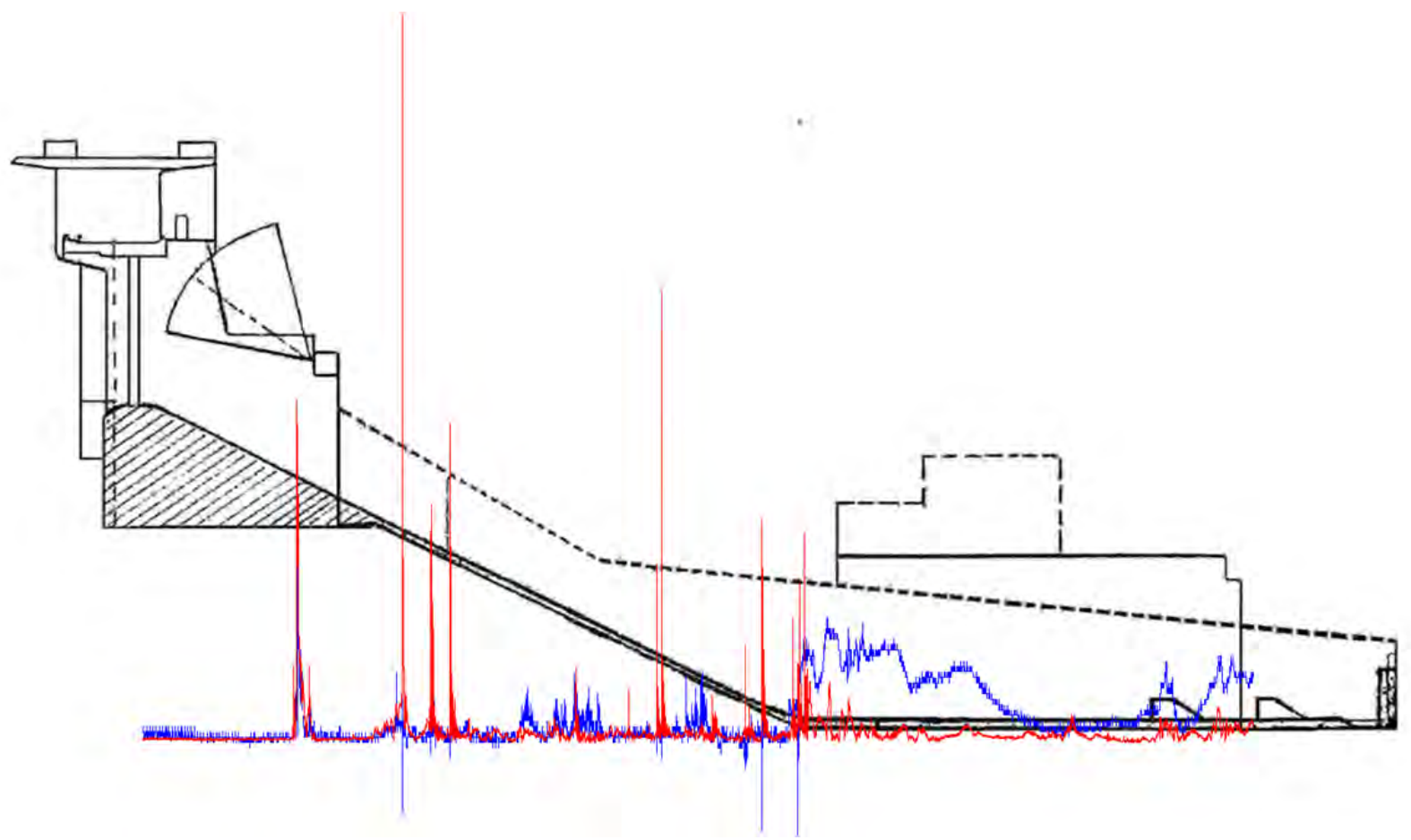

Figure 3.1. Representative Sensor Fish data overlaid on a cross section of the Foster Dam spillway weir showing the approximate locations of selected major timing marks. The blue line is pressure; the red line is acceleration vector magnitude in $g$.

\subsubsection{Penstock/Turbine Passage}

Timing marks used to locate significant events and identify regions of penstock/turbine passage include

1. passage through the penstock

2. passage through the wicket gate region

3. passage through the runner

4. nadir value during passage through the runner

5. passage through the turbine draft tube

6. passage to the tailrace.

Examples of pressure timing marks used for the turbine study are shown in Figure 3.2. 


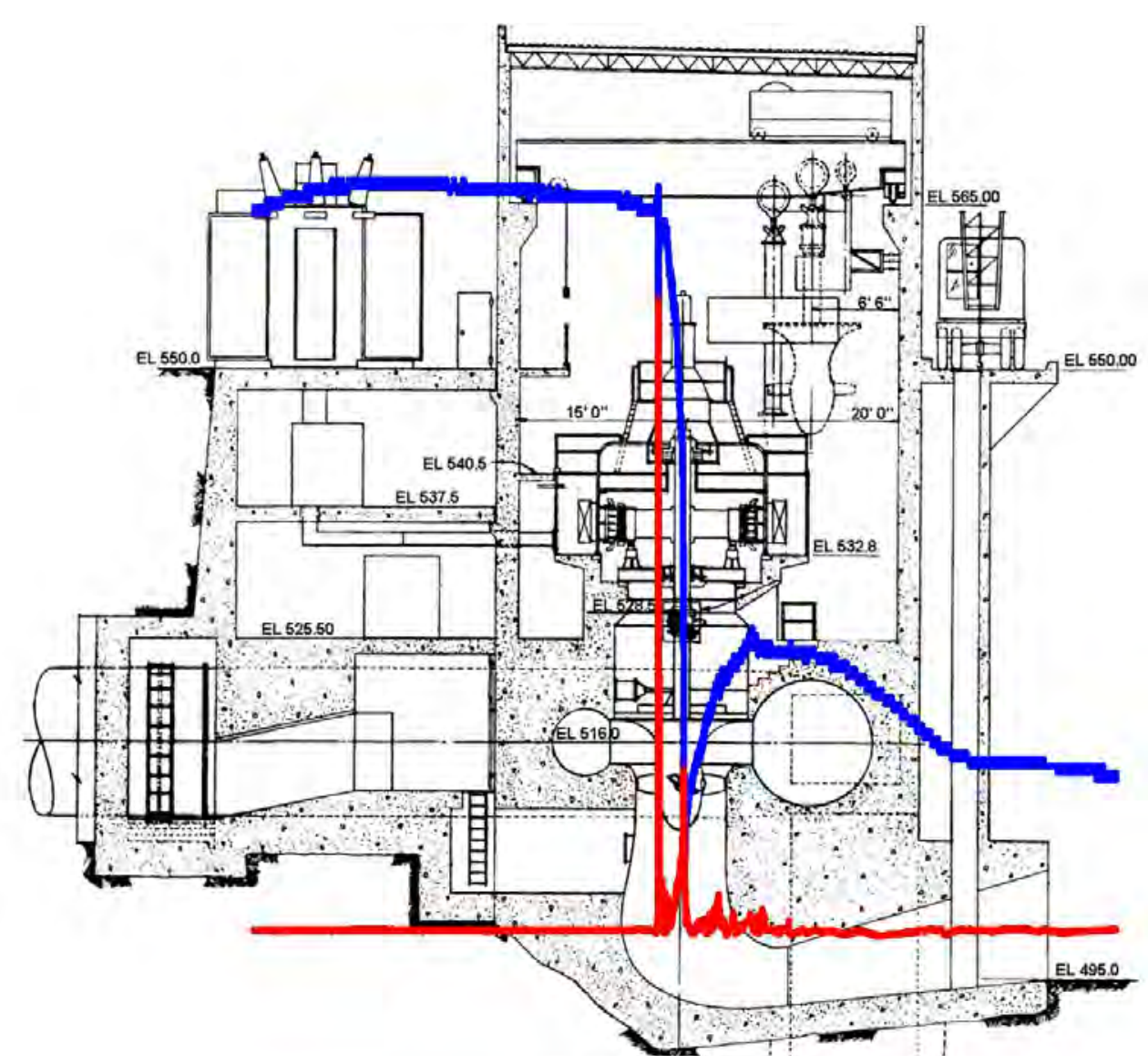

Figure 3.2. Representative Sensor Fish data overlaid on a cross section of the Foster Dam turbine region showing the approximate locations of selected major timing marks. The blue line is pressure; the red line is acceleration vector magnitude in $g$.

Pressure rises as the Sensor Fish passes down the induction pipe to the point of injection into the penstock, gradually increasing as the sensor is carried with penstock flow through decreasing elevation of the penstock. As the Sensor Fish passes through the turbine runner, there is a rapid decrease in pressure. Pressure reaches its lowest point, its nadir, during transit of the suction side of the turbine runner. Following passage through the turbine runner, the Sensor Fish is carried with flow through the turbine draft tube and into the powerhouse tailrace.

\subsection{Collision, Strike, and Shear Events}

A significant event is defined as an impulse in acceleration magnitude greater than or equal to $95 \mathrm{~g}$. Significant events are caused by strike, collision with dam structure, or exposure to shear. All Sensor Fish experienced at least one significant event during spillway fish weir passage, and $62 \%$ experienced at least one significant event during turbine passage. 


\subsubsection{Spillway Fish Weir Passage}

Nearly $81 \%$ of the Sensor Fish experienced more than one significant event during passage over the spillway weir. Significant events were observed at the impact zone of the concrete chute, on the chute as the unit moved down the spillway, at the terminus of the chute as it plunged into the stilling basin, and in the stilling basin/tailrace.

Table 3.3 shows the number of analyzed Sensor Fish data sets by release location and type of the most severe significant event. The greatest severe events were observed as collisions on the spillway chute. At the low-forebay elevation, all of the most severe events were collisions on the chute, while at the high-forebay elevation, $83 \%$ of the most severe events were collisions on the chute and the remaining events were shear.

Table 3.4 summarizes the total number of significant collision and shear events by significant event type and location. Multiple events were most frequent for Sensor Fish passing through the juvenile pipe over the spillway weir at the low-forebay elevation, averaging 5.5 events per Sensor Fish release; the fewest events were observed following passage through the adult pipe at the same low-forebay elevation, averaging approximately 2.5 events per release.

Significant events were observed most frequently on the spillway chute (Figure 3.3); all Sensor Fish experienced at least one collision or shear event at that location or at impact with the chute, regardless of forebay elevation or release pipe used. Sensor Fish passing over the spillway weir at the low-forebay level experienced a greater percentage of events on the chute, presumably due to a more shallow flow depth on the chute. Sensor Fish were more likely to experience shear when passing over the weir at the high-forebay level (Figure 3.4).

Subsequent to passing through the juvenile passage pipe, Sensor Fish passing over the spillway fish weir at the low elevation had the highest mean significant event magnitude (157.6 g); lowest was $136.5 \mathrm{~g}$ following passage over the weir through the adult pipe. Comparing multiple event values, the differences are small, ranging from approximately $123 \mathrm{~g}$ following passage through the adult pipe at the high elevation to $132.6 \mathrm{~g}$ following passage through the juvenile pipe at the lower elevation. The one exceptional difference $(173.9 \mathrm{~g}$ ) occurred for passage through the adult pipe at the low elevation.

The mean acceleration magnitude values for the most severe event per release by event location are shown in Figure 3.5. The highest mean magnitude was observed upon impact with the spillway chute during Sensor Fish passage through the juvenile pipe at the lower weir elevation; passage through the adult pipe at the same elevation also resulted in a high magnitude event. Significant events on the chute were frequent due to depth of flow and the resultant distance from structure, as well as the lengthier exposure times experienced during transit. The mean acceleration magnitude values for all Sensor Fish significant events by event location are shown in Figure 3.6.

Events observed at the plunge and in the stilling basin/tailrace were the minority. Significant events in these regions were observed only for passage through the smaller juvenile release pipe, at both forebay levels. Mean magnitudes were higher for the high-forebay treatment (144.75 $\mathrm{g}$ ) than for the low-forebay treatment $(122.01 \mathrm{~g})$. 
Table 3.3. Location, frequency, and type of the most severe significant event observed for Sensor Fish releases over the spillway weir.

\begin{tabular}{|c|c|c|c|c|c|c|c|c|c|c|c|c|c|c|}
\hline \multirow[b]{2}{*}{$\begin{array}{l}\text { Forebay } \\
\text { (ft MSL) }\end{array}$} & \multirow[b]{2}{*}{ Pipe } & \multirow[b]{2}{*}{$\begin{array}{c}\text { Number } \\
\text { of Data } \\
\text { Sets }\end{array}$} & \multicolumn{4}{|c|}{$\begin{array}{l}\text { Frequency of Occurrence of the Most Severe } \\
\text { Strike Events by Location }\end{array}$} & \multicolumn{4}{|c|}{$\begin{array}{l}\text { Frequency of Occurrence of the Most } \\
\text { Severe Shear Events by Location }\end{array}$} & \multicolumn{4}{|c|}{$\begin{array}{l}\text { Frequency of Occurrence of the Most } \\
\text { Severe Events by Location }\end{array}$} \\
\hline & & & $\begin{array}{l}\text { Chute } \\
\text { Impact }\end{array}$ & $\begin{array}{l}\text { On } \\
\text { Chute }\end{array}$ & $\begin{array}{c}\text { At } \\
\text { Plunge }\end{array}$ & $\begin{array}{c}\text { In } \\
\text { Stilling } \\
\text { Basin/ } \\
\text { Tailrace }\end{array}$ & $\begin{array}{l}\text { Chute } \\
\text { Impact }\end{array}$ & $\begin{array}{l}\text { On } \\
\text { Chute }\end{array}$ & $\begin{array}{l}\text { At } \\
\text { Plunge }\end{array}$ & $\begin{array}{c}\text { In } \\
\text { Stilling } \\
\text { Basin/ } \\
\text { Tailrace }\end{array}$ & $\begin{array}{l}\text { Chute } \\
\text { Impact }\end{array}$ & $\begin{array}{l}\text { On } \\
\text { Chute }\end{array}$ & $\begin{array}{l}\text { At } \\
\text { Plunge }\end{array}$ & $\begin{array}{c}\text { In } \\
\text { Stilling } \\
\text { Basin/ } \\
\text { Tailrace }\end{array}$ \\
\hline \multirow{2}{*}{616} & juvenile & 16 & 8 & 8 & 0 & 0 & 0 & 0 & 0 & 0 & 8 & 8 & 0 & 0 \\
\hline & adult & 2 & 1 & 1 & 0 & 0 & 0 & 0 & 0 & 0 & 1 & 1 & 0 & 0 \\
\hline \multirow{3}{*}{634} & juvenile & 20 & 7 & 10 & 1 & 0 & 2 & 0 & 0 & 0 & 9 & 10 & 1 & 0 \\
\hline & adult & 2 & 0 & 0 & 0 & 0 & 2 & 0 & 0 & 0 & 2 & 0 & 0 & 0 \\
\hline & attached & 2 & 0 & 2 & 0 & 0 & 0 & 0 & 0 & 0 & 0 & 2 & 0 & 0 \\
\hline
\end{tabular}

Table 3.4. Frequency of occurrence of all Sensor Fish significant events by event location and type for Sensor Fish releases over the spillway weir.

\begin{tabular}{|c|c|c|c|c|c|c|c|c|c|c|c|c|c|c|c|c|c|c|}
\hline \multirow[b]{3}{*}{$\begin{array}{l}\text { Forebay } \\
\text { (ft MSL) }\end{array}$} & \multirow[b]{3}{*}{ Pipe } & \multirow[b]{3}{*}{$\begin{array}{c}\text { Number of } \\
\text { Data Sets }\end{array}$} & \multirow[b]{3}{*}{$\begin{array}{l}\text { Single } \\
\text { Event }\end{array}$} & \multirow[b]{3}{*}{$\begin{array}{c}>1 \\
\text { event }\end{array}$} & \multirow[b]{3}{*}{$\begin{array}{l}\text { Total No. } \\
\text { of Events }\end{array}$} & \multirow[b]{3}{*}{$\begin{array}{l}\text { Avg. } \\
\text { No. of } \\
\text { Events }\end{array}$} & \multirow{2}{*}{\multicolumn{4}{|c|}{ Event Location }} & \multicolumn{8}{|c|}{ Event Location and Type } \\
\hline & & & & & & & & & & & \multicolumn{2}{|c|}{ Chute Impact } & \multicolumn{2}{|c|}{ On Chute } & \multicolumn{2}{|c|}{ At Plunge } & \multicolumn{2}{|c|}{$\begin{array}{c}\text { In Stilling } \\
\text { Basin/Tailrace }\end{array}$} \\
\hline & & & & & & & $\begin{array}{l}\text { Chute } \\
\text { Impact }\end{array}$ & $\begin{array}{c}\text { On } \\
\text { Chute }\end{array}$ & $\begin{array}{c}\text { At } \\
\text { Plunge }\end{array}$ & $\begin{array}{c}\text { In } \\
\text { Stilling } \\
\text { Basin/ } \\
\text { Tailrace }\end{array}$ & Strike & Shear & Strike & Shear & Strike & Shear & Strike & Shear \\
\hline \multirow{2}{*}{616} & juvenile & 16 & 1 & 15 & 88 & 5.50 & 13 & 69 & 4 & 2 & 12 & 1 & 69 & 0 & 4 & 0 & 2 & 0 \\
\hline & adult & 2 & 1 & 1 & 5 & 2.50 & 1 & 4 & 0 & 0 & 1 & 0 & 4 & 0 & 0 & 0 & 0 & 0 \\
\hline \multirow{3}{*}{634} & juvenile & 20 & 5 & 15 & 67 & 3.35 & 19 & 46 & 2 & 0 & 11 & 8 & 46 & 0 & 2 & 0 & 0 & 0 \\
\hline & adult & 2 & 0 & 2 & 7 & 3.50 & 2 & 5 & 0 & 0 & 0 & 2 & 5 & 0 & 0 & 0 & 0 & 0 \\
\hline & attached & 2 & 0 & 2 & 10 & 5.00 & 2 & 8 & 0 & 0 & 1 & 1 & 8 & 0 & 0 & 0 & 0 & 0 \\
\hline
\end{tabular}






Figure 3.3. Location of all Sensor Fish significant events by region following spillway weir passage.

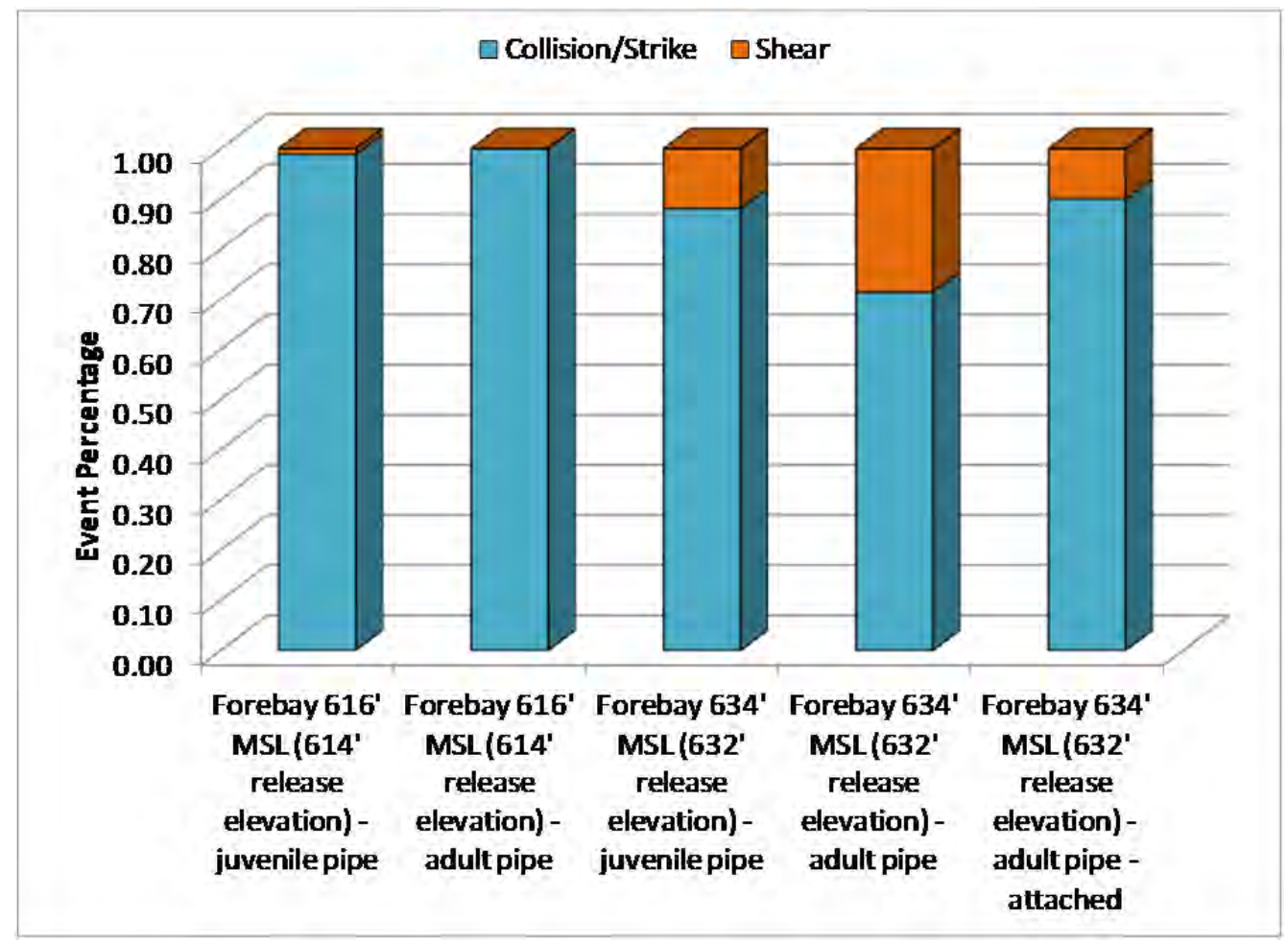

Figure 3.4. Sensor Fish significant event occurrence by type following spillway weir passage. 


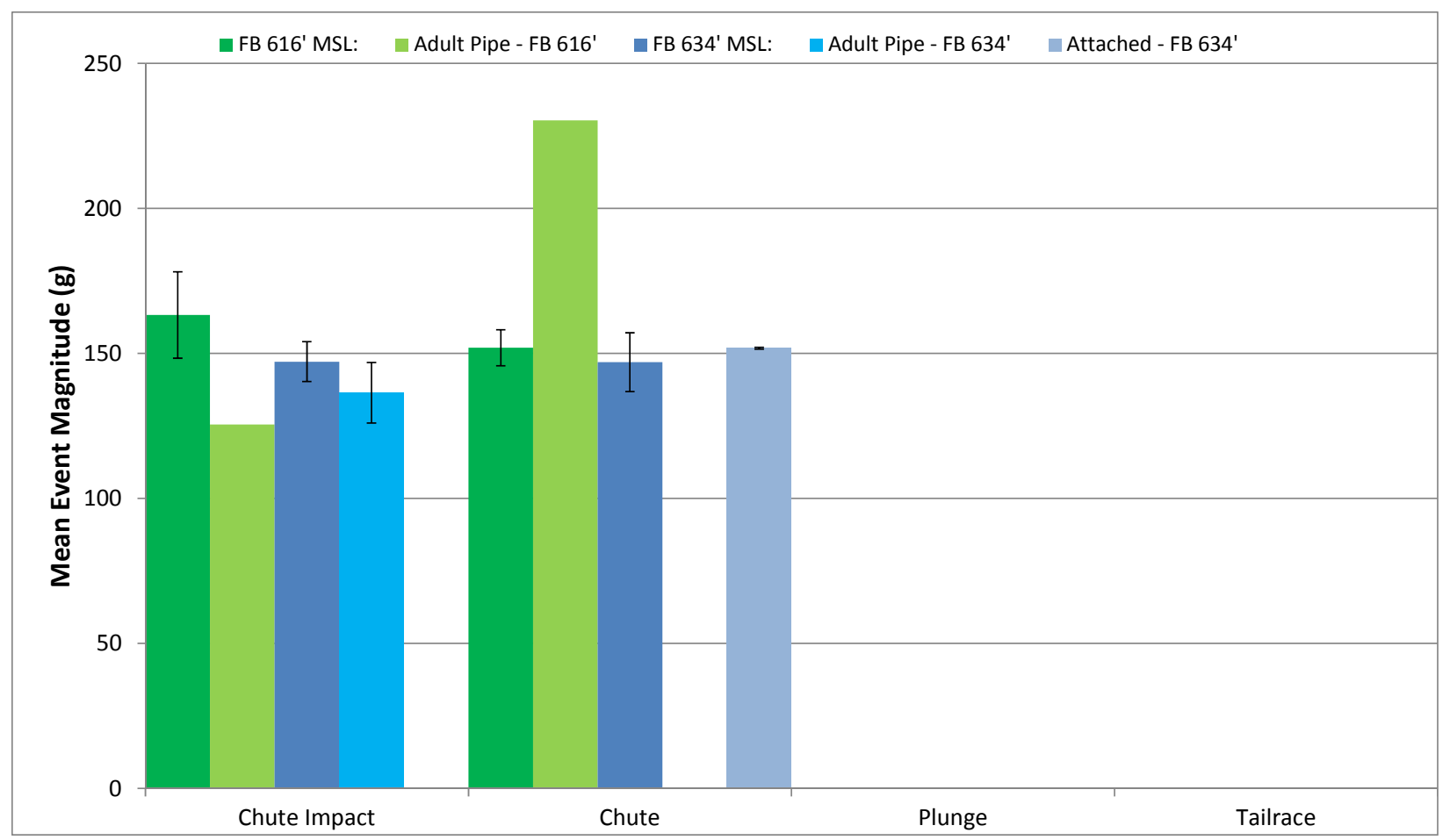

Figure 3.5. Mean acceleration magnitude location for the most severe significant events experienced by Sensor Fish during spillway fish weir passage. Error bars represent standard error of the mean.



Figure 3.6. Mean acceleration magnitude location for all significant events experienced by Sensor Fish during spillway fish weir passage. Error bars represent standard error of the mean. 


\subsubsection{Turbine Passage}

Sixty-two percent of Sensor Fish passing through turbine Unit 1 experienced at least one significant event; 24\% experienced multiple events. No events were observed in the penstock. More than $22 \%$ of the Sensor Fish were damaged or lost during passage through the turbine.

Table 3.5 shows the number of successful Sensor Fish releases and the type and location of the most severe significant event. The majority of the most severe events occurred in the wicket gate-runner region of the turbine; one event occurred in the draft tube. All the events were classified as collisions following turbine passage at the low-forebay level, and $72 \%$ were collisions following passage at the high-forebay level; shear was observed in the runner region only.

Multiple events per Sensor Fish run occurred more frequently during passage at the higher forebay level. The total number of events experienced during turbine passage is summarized in Table 3.6. Nearly all events occurred in the wicket gate-runner region, along with one in the draft tube. The majority of events observed at the high-forebay level occurred in the runner region. Most events occurred in the wicket gate region during Sensor Fish passage at the low-forebay treatment at operational outputs of 6.0 MW and less. Shear events occurred in the runner region only, increasing in frequency with the higher forebay treatment.

The significant event magnitude values for the most severe event experienced by Sensor Fish during passage through turbine Unit 1 were greatest at the low-forebay level-4.9/5.0-MW operation, averaging $152.8 \mathrm{~g}$. Magnitudes were the least, at $128.9 \mathrm{~g}$, for the same operating level but at the high-forebay level. Comparing these values to those from multiple events per condition, the greatest mean acceleration magnitude occurred during Sensor Fish passage at the 2.8/3.0-MW operation (144.8 g) (Figure 3.7). Average multiple event magnitude decreased with turbine operating level at the low-forebay treatment and increased with turbine operating level at the high-forebay treatment.

A rapid pressure decrease occurs during passage through the turbine runner region as the sensor is carried with flow from the pressure to suction sides of the turbine runner. The lowest pressure (nadir) observed during turbine passage occurs as flow passes under the runner blade prior to draft tube entry. The lowest nadir occurred during the high-forebay treatment (634-ft forebay level), when the turbine was operating at 9.0 MW, averaging 14.68 psia. Average nadir was highest (20.59 psia) during low operation (2.8/3.0 MW) at the low-forebay treatment (Figure 3.8).

Pressure rate of change differences among turbine operation treatments were generally associated with turbine flow; that is, the greater the discharge, the higher the observed pressure rate of change. In addition, the forebay levels contributed to higher pressures due to water depth, which usually translated to higher pressure rates of change (Figure 3.9). Sensor Fish data for the deeper passage at the highest operation did not represent the greatest rate of change as expected; which was unexpected. However, the slower data acquisition rate of 200 samples per second for the 3-DOF Sensor Fish may have contributed to this anomaly. 
Table 3.5. Sensor Fish turbine releases showing type of most severe significant event observed. All events occurred in the turbine runner region.

\begin{tabular}{|c|c|c|c|c|c|c|c|c|}
\hline \multirow{2}{*}{$\begin{array}{l}\text { Turbine } \\
\text { Output }\end{array}$} & \multirow{2}{*}{$\begin{array}{l}\text { Number of } \\
\text { Releases }\end{array}$} & \multirow{2}{*}{$\begin{array}{l}\text { Number of } \\
\text { Releases } \\
\text { with Data }\end{array}$} & \multirow{2}{*}{$\begin{array}{c}\text { Number of Sensor } \\
\text { Fish Having at } \\
\text { Least } 1 \text { Event } \\
|\mathrm{a}|>95 \mathrm{~g}\end{array}$} & \multicolumn{2}{|c|}{$\begin{array}{l}\text { Frequency of Occurrence of the } \\
\text { Most Severe Event by Type }\end{array}$} & \multicolumn{3}{|c|}{ Location of the Most Severe Event } \\
\hline & & & & Shear & Collision/Strike & Wicket Gate & Runner & Draft Tube \\
\hline \multicolumn{9}{|c|}{$616 \mathrm{ft}$ MSL } \\
\hline 2.8/3.0 MW & 7 & 6 & 3 & 0 & 1.0 & $2(66.7 \%)$ & $1(33.3 \%)$ & 0 \\
\hline 4.9/5.0 MW & 13 & 9 & 4 & 0 & 1.0 & $3(60 \%)$ & $2(40 \%)$ & 0 \\
\hline $6.0 \mathrm{MW}$ & 10 & 6 & 4 & 0 & 1.0 & $3(75 \%)$ & $1(25 \%)$ & 0 \\
\hline 7.0 MW & 9 & 5 & 2 & 0 & 1.0 & $1(50 \%)$ & $1(50 \%)$ & 0 \\
\hline \multicolumn{9}{|c|}{$634 \mathrm{ft}$ MSL } \\
\hline 4.9/5.0 MW & 8 & 8 & 8 & 0.25 & 0.75 & $1(12.5 \%)$ & $6(75 \%)$ & $1(12.5 \%)$ \\
\hline $6.5 \mathrm{MW}$ & 11 & 8 & 3 & & 1.0 & 0 & $3(100 \%)$ & 0 \\
\hline $9.0 \mathrm{MW}$ & 9 & 8 & 7 & 0.43 & 0.57 & $1(14.3 \%)$ & $6(85.7 \%)$ & 0 \\
\hline
\end{tabular}

Table 3.6. Sensor Fish frequency of occurrence of multiple turbine runner events by type.

\begin{tabular}{|c|c|c|c|c|c|c|c|c|c|c|c|}
\hline \multirow[b]{2}{*}{$\begin{array}{l}\text { Turbine } \\
\text { Output }\end{array}$} & \multirow{2}{*}{$\begin{array}{c}\text { Number } \\
\text { of Data } \\
\text { Sets }\end{array}$} & \multirow[b]{2}{*}{$\begin{array}{c}\text { No } \\
\text { Event }\end{array}$} & \multirow[b]{2}{*}{$\begin{array}{l}\text { Single } \\
\text { Event }\end{array}$} & \multirow[b]{2}{*}{$\begin{array}{c}>1 \\
\text { Event }\end{array}$} & \multirow{2}{*}{$\begin{array}{c}\text { Total } \\
\text { Number } \\
\text { of } \\
\text { Events }\end{array}$} & \multirow{2}{*}{$\begin{array}{c}\text { Average } \\
\text { Number of } \\
\text { Events per } \\
\text { Condition }\end{array}$} & \multicolumn{2}{|c|}{ Event Type } & \multicolumn{3}{|c|}{ Event Location } \\
\hline & & & & & & & $\begin{array}{l}\text { Collision/ } \\
\text { Strike }\end{array}$ & Shear & $\begin{array}{l}\text { Wicket } \\
\text { Gate }\end{array}$ & Runner & Draft Tube \\
\hline \multicolumn{12}{|c|}{$616 \mathrm{ft}$ MSL } \\
\hline 2.8/3.0 MW & 6 & 3 & 3 & 0 & 3 & 0.50 & $3(100 \%)$ & 0 & $2(66.7 \%)$ & $1(33.3 \%)$ & 0 \\
\hline 4.9/5.0 MW & 9 & 5 & 2 & 2 & 8 & 0.89 & 7 (87.5\%) & 1 (12.5\%) & 4 (50\%) & $4(50 \%)$ & 0 \\
\hline 6.0 MW & 6 & 2 & 4 & 0 & 4 & 0.67 & $4(100 \%)$ & 0 & 3 (75\%) & $1(25 \%)$ & 0 \\
\hline 7.0 MW & 5 & 3 & 1 & 1 & 3 & 0.60 & 3 (100\%) & 0 & 1 (33.3\%) & 2 (66.7\%) & 0 \\
\hline \multicolumn{12}{|c|}{$634 \mathrm{ft}$ MSL } \\
\hline 4.9/5.0 MW & 8 & 0 & 5 & 3 & 12 & 1.50 & 9 (75\%) & 3 (25\%) & 3 (25\%) & 8 (66.7\%) & 1 (8.3\%) \\
\hline $6.5 \mathrm{MW}$ & 8 & 5 & 1 & 2 & 5 & 0.63 & $4(80 \%)$ & $1(20 \%)$ & 0 & 5 (100\%) & 0 \\
\hline 9.0 MW & 8 & 1 & 4 & 3 & 11 & 1.38 & 8 (72.7\%) & 3 (27.3\%) & 2 (18.2\%) & 9 (81.8\%) & 0 \\
\hline
\end{tabular}




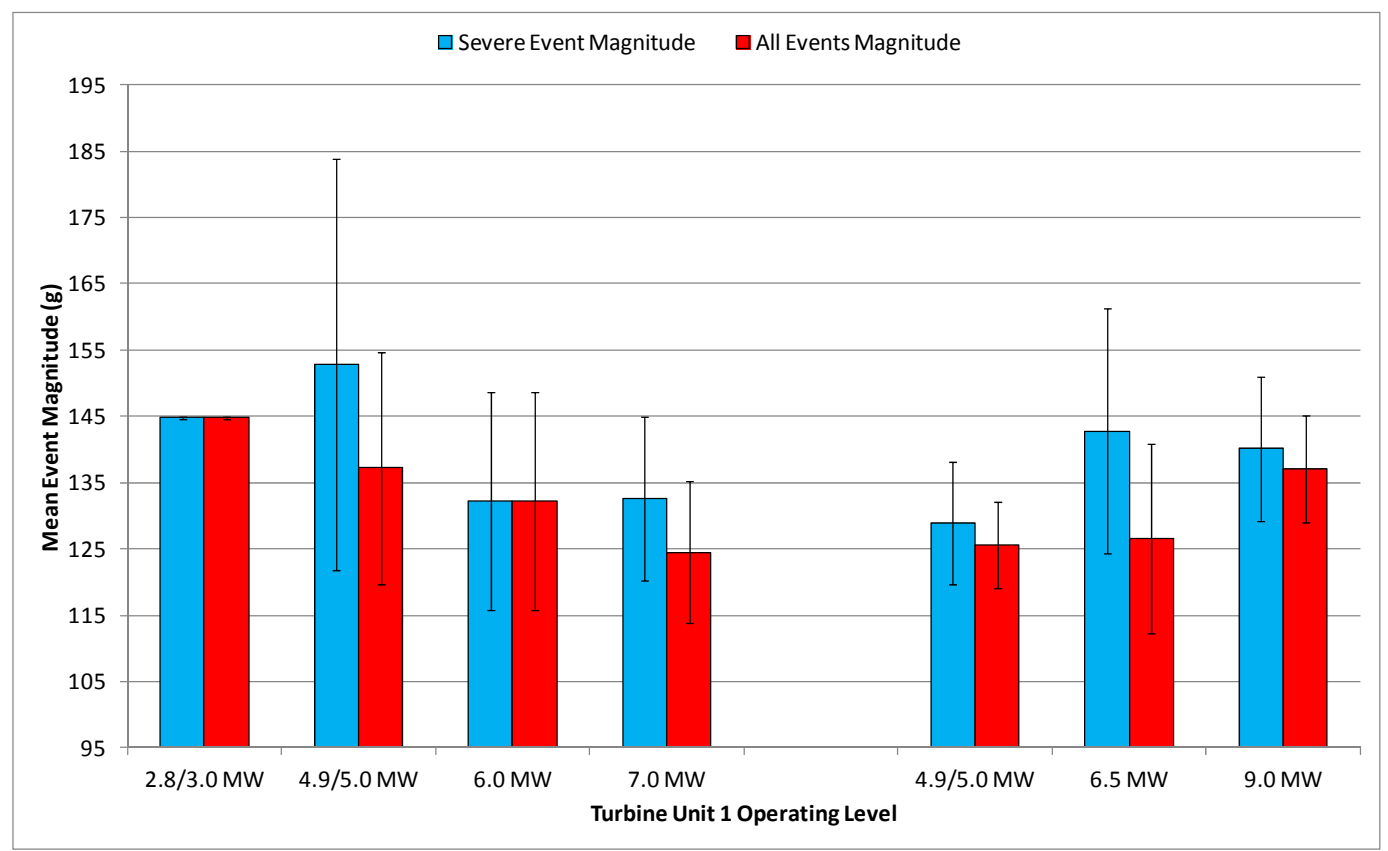

Figure 3.7. Sensor Fish event magnitudes for the most severe event and cumulative events by turbine operation. Error bars represent standard error of the mean.

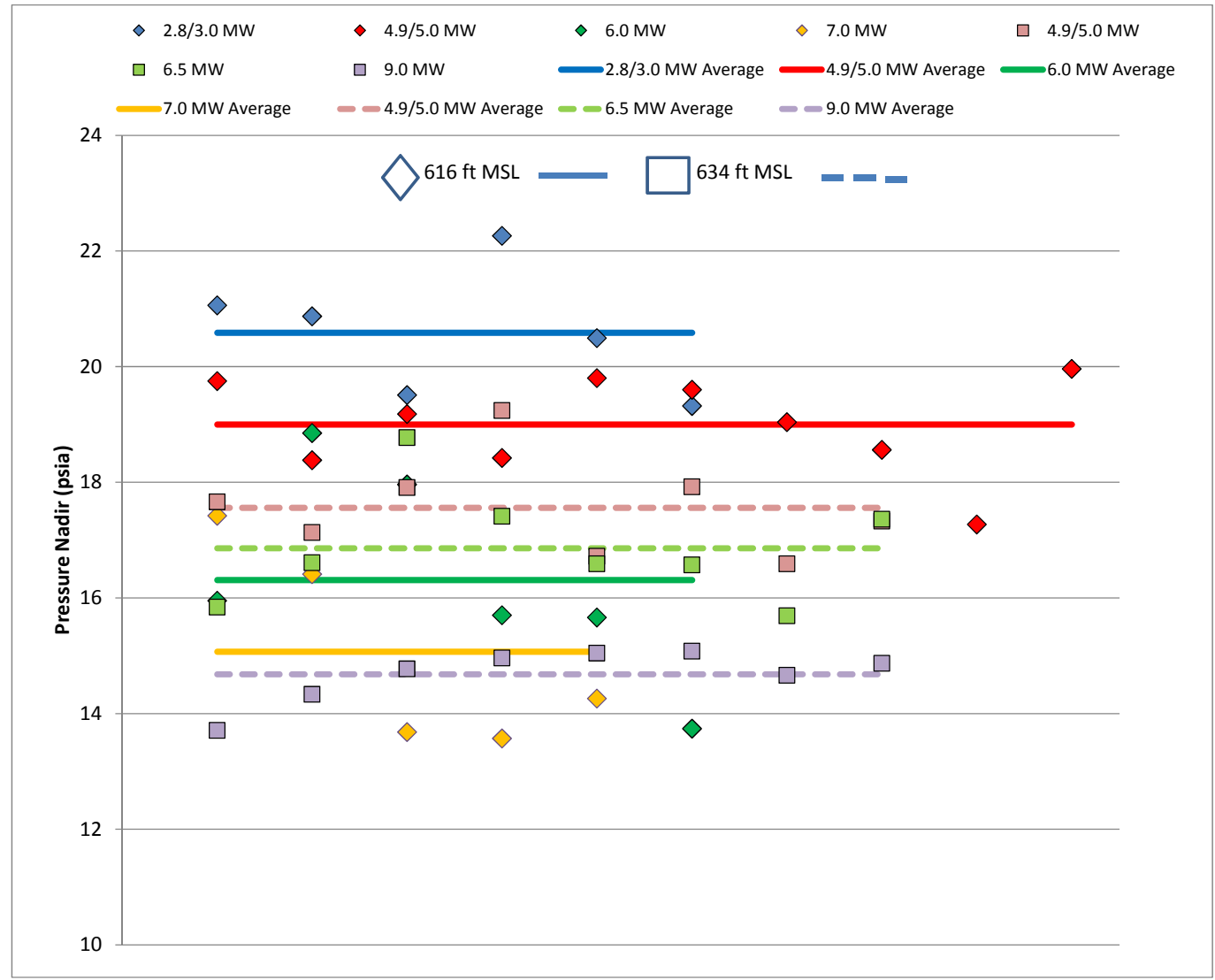

Figure 3.8. Nadir pressures observed during passage through Foster Dam turbine Unit 1 as measured by Sensor Fish. 


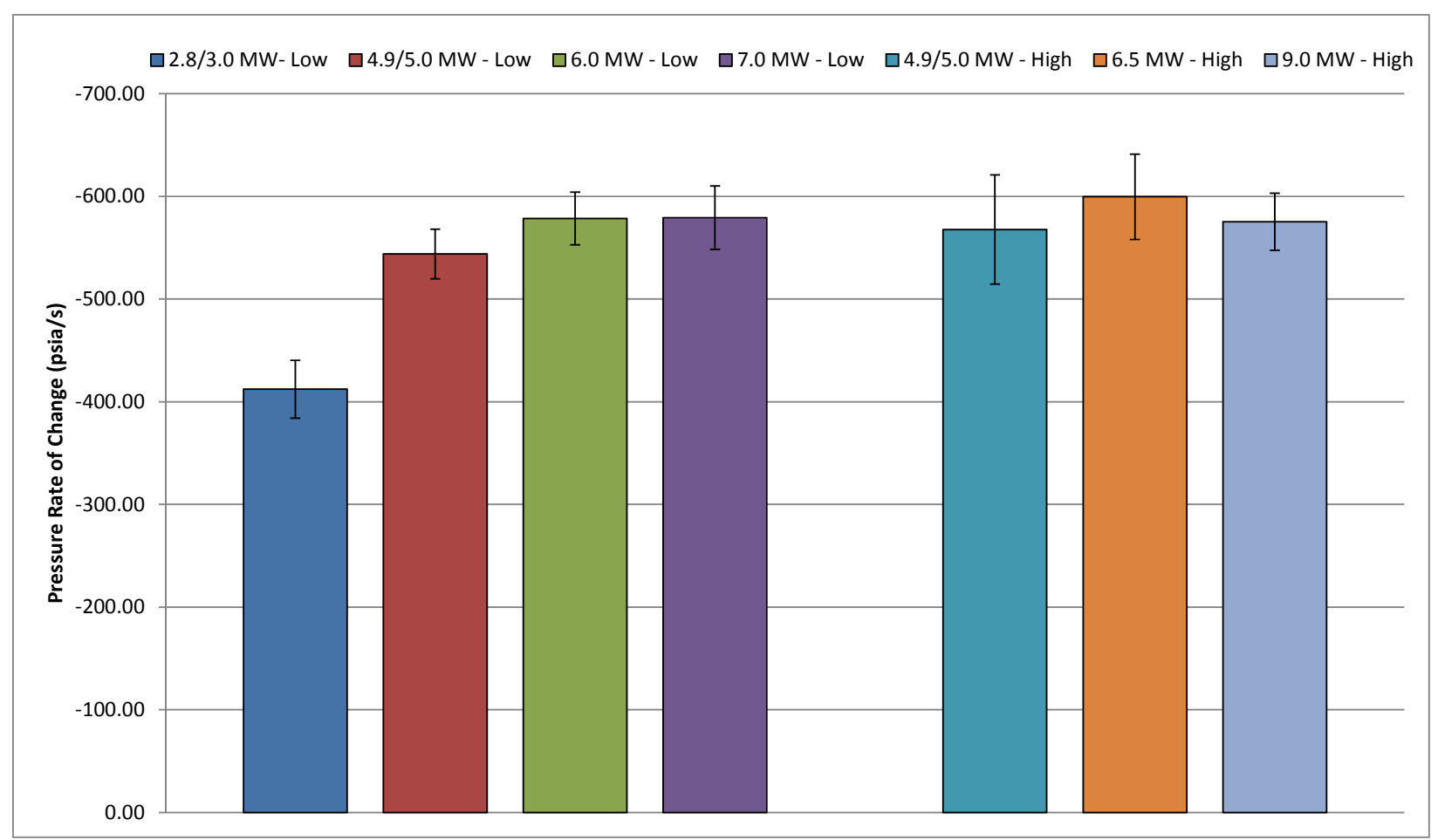

Figure 3.9. Average pressure rate of change through Foster Dam turbine Unit 1. Error bars represent standard error of the mean.

\subsection{Turbulence Index}

The turbulence index as it is used here is a subjective measure developed by computing the area (integrating) under the acceleration magnitude and angular rate-of-change magnitude curves for a given period, with the premise that larger area equates to greater turbulence. A 7-s period following spillway weir passage was used, and $10 \mathrm{~s}$ (5 s prior to the runner nadir and 5 subsequent seconds) was applied for turbine passage. Each time segment encompasses the most turbulent passage interval for all passage treatments. Computed areas were normalized to seconds for evaluation purposes.

The turbulence index values for passage over the spillway fish weir and the associated tumbling down the spillway chute were highest. Turbulence index values were lower during turbine runner passage; highest values were recorded at the low-forebay level at the 2.8/3.0-MW treatment, followed by the highforebay low- and high-MW treatments (Table 3.7). Limited available data for Sensor Fish with angular rate of change capability in the high-forebay turbine may be distorting the results, as only one or two data sets were produced. Turbulence index for the lowest turbine operation was highest, indicating the lower flows through the unit were less uniform. 
Table 3.7. Computed area under the curve for angular rate-of-change and acceleration magnitudes per second (turbulence index).

\begin{tabular}{lccc}
\hline & $\begin{array}{c}\text { Area - Acceleration } \\
\text { Magnitude } \\
\text { per Second }\end{array}$ & $\begin{array}{c}\text { Area - Angular Rate-of- } \\
\text { Change Magnitude } \\
\text { per Second }\end{array}$ & $\begin{array}{c}\text { Combined Area } \\
\text { per Second }\end{array}$ \\
\hline Passage Route and Condition & 2.2 & 781 & 783 \\
\hline $\begin{array}{l}\text { Spillway Fish Weir - Low Forebay } \\
\text { Juvenile Pipe }\end{array}$ & 2.0 & 664 & 666 \\
$\quad$ Adult Pipe & 2.3 & 756 & 758 \\
Spillway Fish Weir - High Forebay & 2.6 & 780 & 783 \\
Juvenile Pipe & & & \\
Adult Pipe & 2.9 & 491 & 494 \\
Turbine Unit 1 - Low Forebay & 2.0 & 337 & 339 \\
2.8/3.0 MW & 2.0 & 349 & 351 \\
4.9/5.0 MW & 2.0 & 352 & 418 \\
6.0 MW & & & 376 \\
7.0 MW & 6.8 & 411 & 417 \\
Turbine Unit 1 - High Forebay & 2.9 & 373 & 413 \\
4.9/5.0 MW & 4.1 & & \\
6.5 MW & & & \\
9.0 MW & & &
\end{tabular}

\subsection{Comparison of Sensor Fish and Live-Fish Data}

Live-fish HI-Z-tag studies were conducted by Normandeau concurrent with the Sensor Fish studies at Foster Dam. Normandeau scientists released live fish through the same injection systems as the Sensor Fish, under the same test conditions. In most cases, Sensor Fish releases were interspersed with live-fish releases.

A total of 442 juvenile and 104 adult steelhead and 51 Sensor Fish were released over the spillway fish weir at two forebay elevations at Foster Dam. Table 3.8 shows fish release and recapture rates, estimated survival rate, and malady-free rate for live fish (Normandeau 2013). A total of 1,238 juvenile steelhead and 67 Sensor Fish were released into turbine Unit 1 at all operational levels (Table 3.9).

For comparison with Sensor Fish magnitudes, the reciprocal of the malady-free rate is reported as the injury or malady rate; the reciprocal of survival is reported as mortality.

Figure 3.10 shows live-fish malady and mortality rates along with the Sensor Fish average significant event magnitudes for spillway fish weir passage. Flow over the weir was thin, providing no cushioning effect at impact and during chute passage for the Sensor Fish. As a result, most exhibited a substantial significant event upon colliding with the concrete, along with additional events during the path down the chute. 
Table 3.8. Mortality and malady rates of steelhead released over the spillway fish weir at Foster Dam compared with hydraulic information obtained by Sensor Fish, May 2012.

\begin{tabular}{|c|c|c|c|c|}
\hline \multirow[b]{2}{*}{ Target Elevation (ft) } & \multicolumn{2}{|c|}{ Elevation 614} & \multicolumn{2}{|c|}{ Elevation 632} \\
\hline & Juvenile & Adult & Juvenile & Adult \\
\hline \multicolumn{5}{|l|}{ Mortality } \\
\hline Sample size & 193 & 55 & 249 & 49 \\
\hline Mortality rate (48 h) & 0.005 & 0.000 & 0.056 & 0.225 \\
\hline SE & 0.005 & 0.000 & 0.015 & 0.057 \\
\hline \multicolumn{5}{|l|}{ Malady } \\
\hline Sample size $\mathrm{e}^{(\mathrm{a})}$ & 193 & 55 & 248 & 49 \\
\hline Malady rate (48 h) & 0.063 & 0.016 & 0.181 & 0.400 \\
\hline SE & 0.014 & 0.110 & 0.025 & 0.101 \\
\hline \multicolumn{5}{|c|}{ Sensor Fish } \\
\hline Sample size & 16 & 2 & 20 & 4 \\
\hline Severe event magnitude & 157.6 & 178.0 & 147.0 & 144.1 \\
\hline SE & 7.95 & 52.45 & 5.99 & 6.16 \\
\hline All events magnitude & 128.5 & 173.9 & 132.6 & 123.5 \\
\hline SE & 3.01 & 18.52 & 3.33 & 4.13 \\
\hline$\%$ with significant event & 1.0 & 1.0 & 1.0 & 1.0 \\
\hline Turbulence index & 783 & 666 & 758 & 783 \\
\hline SE & 29.7 & 67.3 & 23.6 & 17.7 \\
\hline
\end{tabular}


Table 3.9. Mortality and malady rates of steelhead released through Unit 1 turbine at Foster Dam compared with hydraulic information obtained by Sensor Fish, May 2012.

\begin{tabular}{|c|c|c|c|c|c|c|c|}
\hline \multirow[b]{2}{*}{ Unit Output } & \multicolumn{4}{|c|}{ Elevation 614} & \multicolumn{3}{|c|}{ Elevation 632} \\
\hline & 2.8/3.0 MW & 4.9/5.0 MW & $6.0 \mathrm{MW}$ & $7.0 \mathrm{MW}$ & 4.9/5.0 MW & $6.5 \mathrm{MW}$ & $9.0 \mathrm{MW}$ \\
\hline \multicolumn{8}{|c|}{ Live Fish } \\
\hline \multicolumn{8}{|l|}{ Mortality } \\
\hline Sample size & 100 & 196 & 150 & 185 & 209 & 200 & 198 \\
\hline Mortality rate (48 hr) & 0.210 & 0.184 & 0.260 & 0.146 & 0.118 & 0.241 & 0.207 \\
\hline SE & 0.041 & 0.028 & 0.036 & 0.026 & 0.023 & 0.030 & 0.029 \\
\hline \multicolumn{8}{|l|}{ Malady } \\
\hline Sample size ${ }^{(a)}$ & 92 & 189 & 137 & 182 & 202 & 195 & 193 \\
\hline Malady rate (48 hr) & 0.228 & 0.254 & 0.285 & 0.181 & 0.193 & 0.261 & 0.207 \\
\hline $\mathrm{SE}$ & 0.044 & 0.032 & 0.039 & 0.029 & 0.028 & 0.032 & 0.029 \\
\hline \multicolumn{8}{|c|}{ Sensor Fish } \\
\hline Sample size & 6 & 9 & 6 & 5 & 8 & 8 & 8 \\
\hline Severe event magnitude & 144.8 & 152.8 & 132.2 & 132.6 & 128.9 & 142.8 & 140.1 \\
\hline SE & 0.167 & 30.99 & 16.5 & 12.35 & 9.25 & 18.49 & 10.91 \\
\hline All events magnitude & 144.8 & 137.15 & 132.2 & 124.5 & 125.6 & 126.6 & 137.0 \\
\hline SE & 0.167 & 17.48 & 16.5 & 10.75 & 6.52 & 14.31 & 8.07 \\
\hline \% with significant event & 0.50 & 0.44 & 0.67 & 0.40 & 1.0 & 0.38 & 0.88 \\
\hline Turbulence index & 494 & 339 & 351 & 354 & 418 & 376 & 417 \\
\hline SE & 43.8 & 42.4 & 22.4 & 14.3 & 11.8 & NA & 137.2 \\
\hline Pressure rate of change & -412.2 & -543.7 & -578.5 & -579.2 & -567.8 & -599.6 & -575.2 \\
\hline SE & 28.2 & 24.12 & 25.7 & 30.9 & 53.2 & 41.5 & 27.8 \\
\hline
\end{tabular}

(a) Based on only recaptured fish.

NA = Not applicable. 


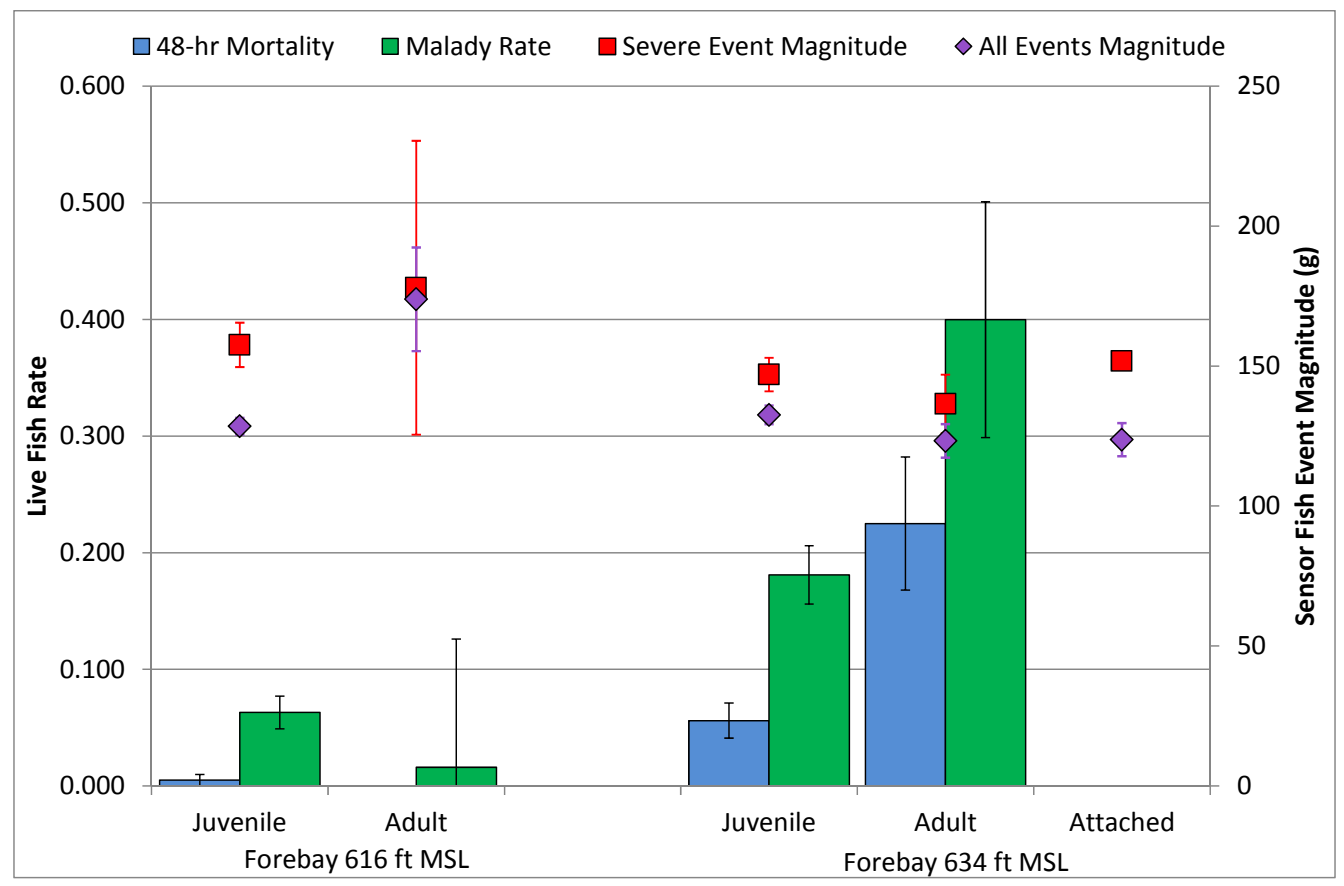

Figure 3.10. Live-fish mortality and malady estimates contrasted with Sensor Fish significant event magnitudes for passage over the spillway fish weir. Error bars represent standard error of the mean.

Sensor Fish were attached directly to two individual adult steelhead. Multiple significant events were recorded during passage, all of which occurred on the spillway chute. Readings from one Sensor Fish (No. 214) showed events at impact and during transit down the chute, while the readings from the other Sensor Fish (No. 250) indicated an event at impact and immediately afterward, but none during passage down the spillway chute. The steelhead with Sensor Fish No. 214 attached had a bruise at recapture, and that with No. 250 attached had scrapes on the head near the eye; both were fine after $48 \mathrm{hr}$.

Figure 3.11 shows live-fish malady and mortality rates along with the Sensor Fish average significant event magnitudes ( \pm standard error of the mean) for passage through turbine Unit 1 . The severe event magnitude generally trends with the malady estimate, and the 48-hr mortality estimate trends with the multiple events average magnitudes, with the exception of the 6.5-MW treatment, regardless of forebay level. The explanation for the higher injury and mortality rates during this turbine operation is not obvious and may be the result of the interaction of several conditions.

Sensor Fish passage through turbine Unit 1 at the 6.0-MW operation, low-forebay treatment were more likely to experience a significant event- $80 \%$ compared with less than $50 \%$ for the other lowforebay operations tested. However, at the high-forebay treatment, the opposite was observed (fewer events were experienced at the 6.5-MW operation), although more Sensor Fish were lost or damaged.

Turbulence index values from the Sensor Fish indicate the passage route through the turbine at the 6.5-MW operations was actually less turbulent than the other operational conditions at the high-forebay treatment; the 6.0-MW operation was essentially the same as the other operational conditions for all but the 2.8/3.0-MW operations at the low-forebay level, which exhibited the highest turbulence for turbine passage (Figure 3.12). 




Figure 3.11. Live-fish mortality and malady estimates contrasted with Sensor Fish significant event magnitudes through turbine Unit 1. Error bars represent standard error of the mean.

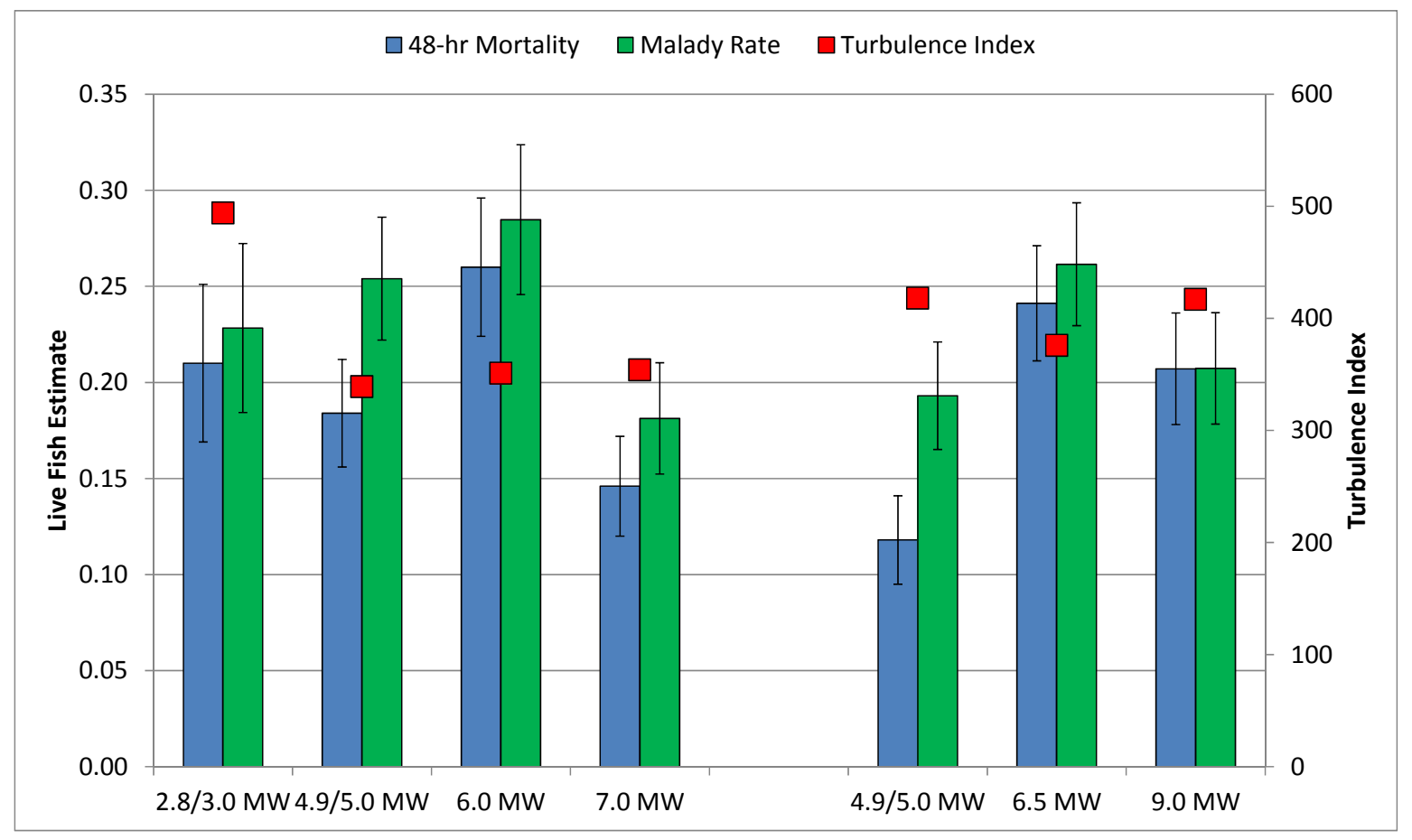

Figure 3.12. Live-fish mortality and malady estimates contrasted with the Sensor Fish turbulence index for passage through turbine Unit 1. Error bars represent standard error of the mean. 
Pressure rate-of-change differences among turbine operation treatments are usually associated with turbine flow; that is, the greater the discharge and larger the head, the higher the observed pressure rate of change. Live-fish malady estimates trend somewhat with the rate-of-change values (Figure 3.13).



Figure 3.13. Live-fish mortality and malady estimates contrasted with the Sensor Fish pressure rate of change during passage through turbine Unit 1. 


\subsection{Discussion}

The objective of this study was to describe and compare passage exposure conditions through the spillway fish weir and turbine Unit 1 at Foster Dam using Sensor Fish to identify operations and structural features that might cause fish injury or mortality.

\subsection{Spillway Fish Weir Passage}

Sensor Fish were used to evaluate the spillway fish weir at forebay elevations of approximately $616 \mathrm{ft}$ and $634 \mathrm{ft}$ MSL. Weir flow rates varied for each test elevation, ranging from 154 to $169 \mathrm{cfs}$ at the lower forebay (616.1 to $616.2 \mathrm{ft}$ MSL) and 120 to $230 \mathrm{cfs}$ at the higher forebay (633.7 to $634.6 \mathrm{ft}$ MSL). Weir elevations were $614 \mathrm{ft}$ and $632 \mathrm{ft}$ for the low- and high-forebay levels, respectively, and the injection system pipes were placed $1 \mathrm{ft}$ above the spillway weir crest.

Weir flow impacted the spillway chute surface and then coursed down the chute into the stilling basin (Figure 4.1). Distances from the injection pipe exit to impact (based on the spillway crest elevation of $596.8 \mathrm{ft}$ ) were approximately 18 and $36 \mathrm{ft}$ for the two forebay elevations, respectively. Sensor Fish velocities prior to impact were estimated to be 40 and $52 \mathrm{ft} / \mathrm{s}$ for the low- and high-forebay levels, respectively. Impact force of the Sensor Fish was calculated to be 1,862 and 3,185 N (419 and 716 pounds force) for the low- and high-forebay levels, respectively.

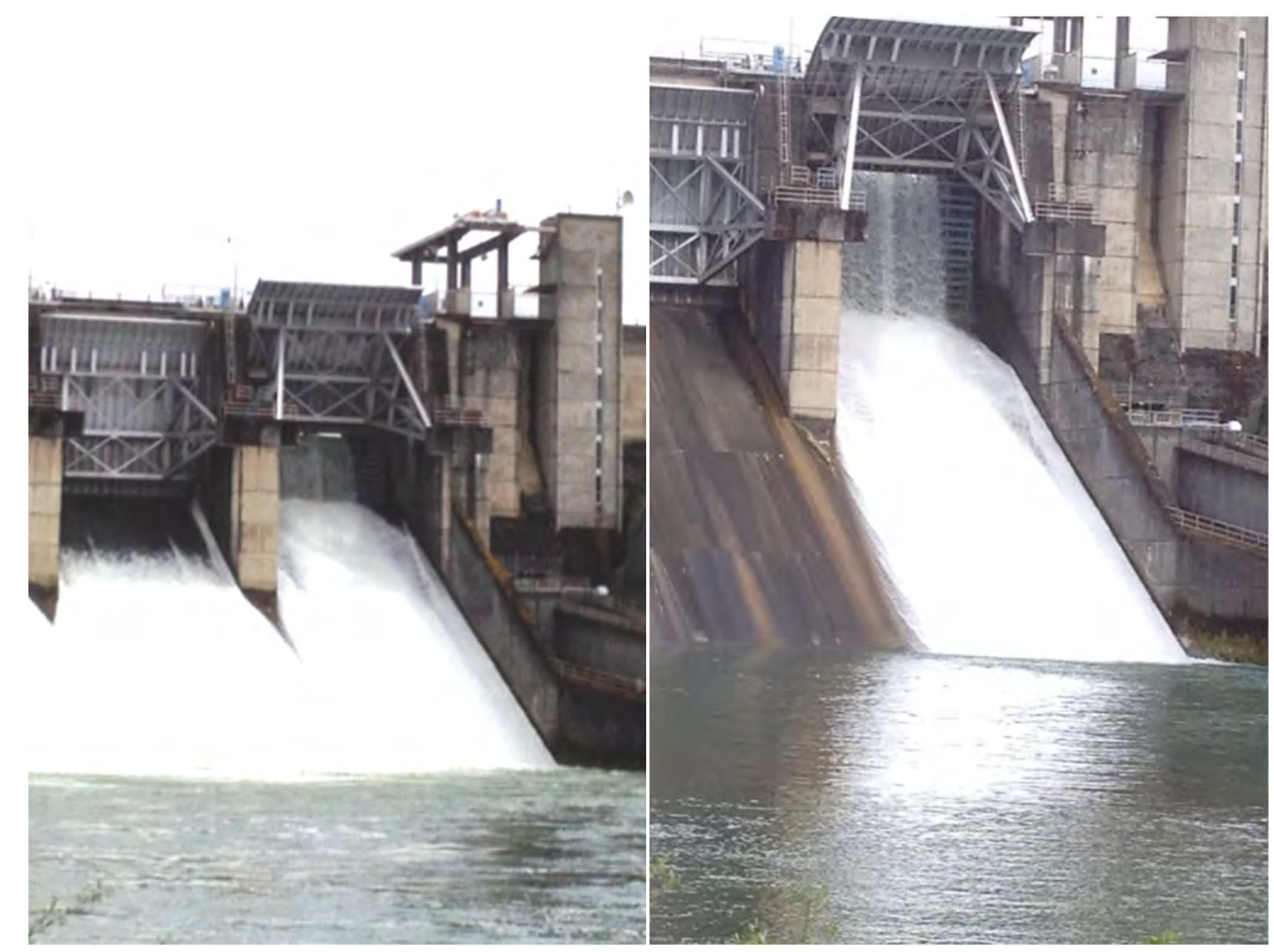

Figure 4.1. Spillway weir flow impacts the concrete chute prior to flowing into the stilling basin. 
Previous studies at dams on the Columbia and Snake rivers and the Willamette tributaries revealed a relationship between Sensor Fish data and live-fish mortality and injury. The nature of the relationship between live fish and Sensor Fish data was not explicitly clear for the spillway fish weir evaluation at Foster Dam, as the weir presents unique conditions that are atypical compared to those for similar weir configurations and characteristics of discharge over the weirs at mainstem Columbia and Snake river dams.

An evaluation was conducted at John Day Dam in 2008 using Sensor Fish and balloon-tagged juvenile Chinook salmon (Normandeau et al. 2008; Carlson and Duncan 2009). John Day Dam has a top spill weir in two spillbays that have been used successfully to aid in juvenile fish passage. The weir design is similar to that at Foster Dam, in that the inserts are placed in the bulkhead slot, forming a flattopped weir, and water flows over the weir where discharge is controlled by the forebay elevation. The flow over the spillway weir forms a broad, relatively thin discharge jet that impacts the spillway surface before flowing down the spillway chute into the stilling basin (Figure 4.2).

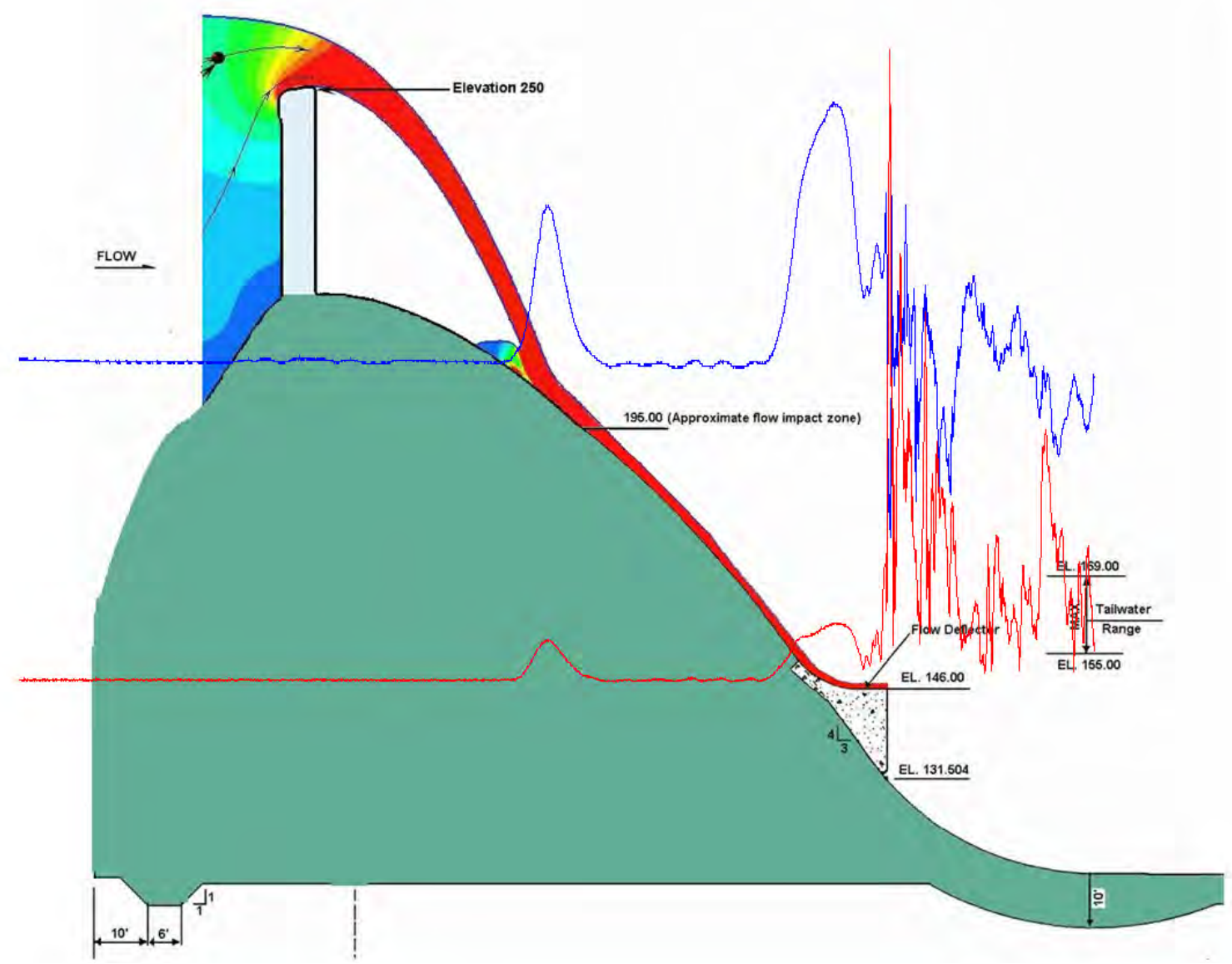

Figure 4.2. Spill over the weir at John Day Dam with Sensor Fish data superimposed. The blue line is pressure; the red line is acceleration vector magnitude in $g$.

Comparing the spillways at Foster and John Day dams, the slope of the latter has a greater horizontal component, resulting in a trajectory with an angle of approximately 50 degrees, while that at Foster is approximately 25 degrees (Figure 4.3). Flow over the weir at John Day was maintained at approximately 
$9.6 \mathrm{kcfs}$ with a flow depth of approximately $6.4 \mathrm{ft}$. The force of the discharge over the weir created a jet with a trajectory that caused the jet to land on the spillway chute at a horizontal distance of approximately 35 to $40 \mathrm{ft}$ downstream of the weir and approximately $14 \mathrm{ft}$ below the elevation of the spillway crest (Figure 4.2). The impact of fish carried in the John Day discharge jet onto the concrete at John Day is relatively benign, as the flow depth was greater than $2 \mathrm{ft}$ during the entire chute passage, and fish passing were entrained within the body of the discharge jet. Thus, no significant events were observed in the Sensor Fish data in this section of weir passage. Fish contained within the discharge jet would not impact on the spillway chute but would be retained within the discharge jet away from the spillway surface as the discharge jet was redirected at impact to follow the spillway chute.

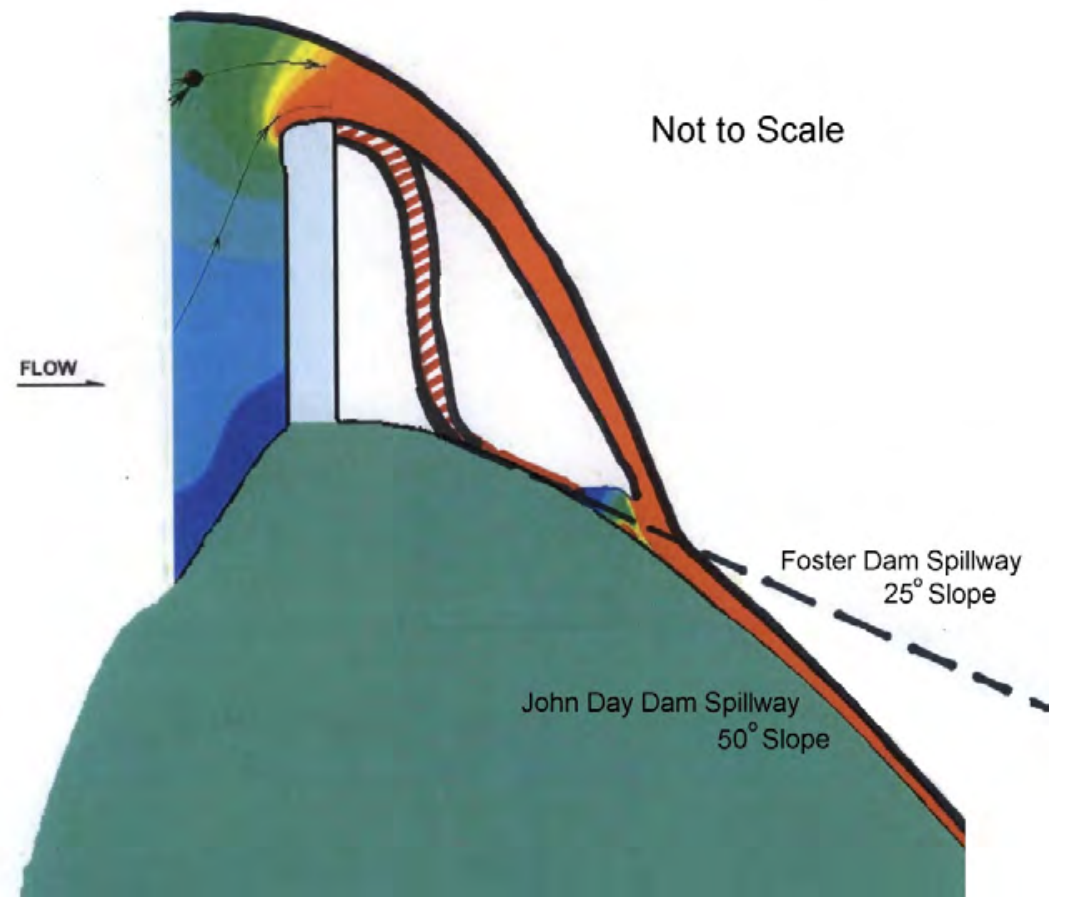

Figure 4.3. Comparison of spillways at John Day Dam and Foster Dam.

Depth of flow on the spillway was very shallow at Foster Dam because the discharge jet was poorly formed due to small discharge flow rates. The discharge over the spillway weir at Foster did not form a defined jet but was rather a shallow disorganized flow that had little forward momentum prior to impact on the spillway chute surface. The Sensor Fish is made of rigid polycarbonate and has no shockabsorbing capability. The Sensor Fish collided with the concrete at least once during each release and as many as 12 times as it traveled down the chute. The depth of flow on the spillway was insufficient to keep the Sensor Fish within the discharge flow and away from the spillway chute concrete surface, unlike that during the study at John Day Dam. The majority of significant events recorded by the Sensor Fish were those observed as it traversed the spillway. A few significant events were observed during entry of the Sensor Fish into the stilling basin upon exit from the spillway chute. However, these events were relatively minor for the low-forebay condition, averaging $122 \mathrm{~g}$, and somewhat more harsh for the highforebay treatment, averaging $145 \mathrm{~g}$.

The characteristics of the fish injection systems used at John Day and Foster dams differed as well. At John Day Dam, the injection pipe was installed upstream of the spillway at a depth of approximately 
$6.5 \mathrm{ft}$, so that Sensor Fish and live test fish were entrained in discharge flow during weir passage. At Foster, the injection pipe was installed on top of the spillway weir crest to ensure the fish would pass, because the depth of flow over the weir was less than $2 \mathrm{ft}$ and the water velocities were low just upstream of the weir. Fish were occasionally observed to be propelled out of the pipe and were easily observed in mid-air before falling onto the spillway concrete surface (Figure 4.4).
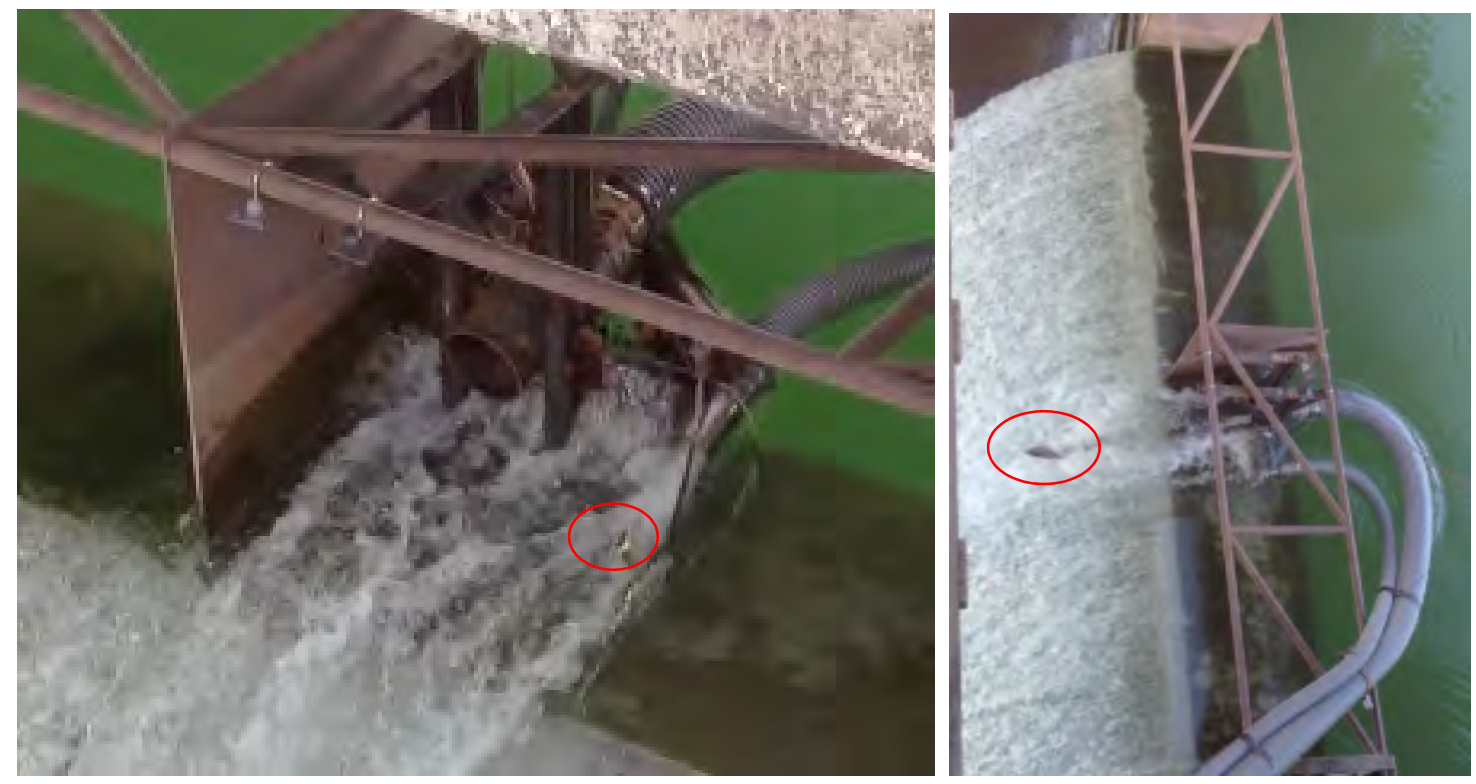

Figure 4.4. Fish injection system pipe attachment at Foster Dam and juvenile (left) and adult (right) steelhead being propelled out of the system during testing.

Flow over the spillway weir at Foster Dam was variable, ranging from 154 to 169 cfs for the lowforebay condition and from 120 to $230 \mathrm{cfs}$ for the high-forebay treatment. Depth of flow also varied; intended flow depth over the weir was 1 to $2 \mathrm{ft}$. Given that the flow at Foster was low, the horizontal component of the discharge over the weir was much less than that at John Day; further, the trajectory of water and fish upon passing over the weir was almost vertical onto the concrete surface of the spillway chute. The horizontal component of the weir discharge trajectory was estimated to be approximately 3 to $5 \mathrm{ft}$. The Foster spillway chute angle also contributes to the probability of injury to fish passing over the weir because more of the change in momentum when the fish impacts the spillway surface is likely to go into deformation of the fish's body than change in direction (Figure 4.5).

The nearly vertical drop after exiting the injection pipe, coupled with the fact that some of the fish were not entrained in the flow prior to passage over the spillway weir, likely contributed to injuriesespecially at the higher forebay level (i.e., longer drop). Given the mass of the fish and the distance to concrete, impact force can be estimated. Sensor Fish, with a mass of approximately $0.05 \mathrm{~kg}$ (with attached balloons and radio tag) had an estimated impact force of 1,862 and 3,185 N (419 and 716 pounds force) for the low- and high-forebay levels, respectively. Considering the observed mass of a juvenile steelhead (average $212 \mathrm{~mm}$ fork length) as $0.11 \mathrm{~kg}$ and that of an adult (average $708 \mathrm{~mm}$ fork length) as $4.2 \mathrm{~kg}$, estimated impact force would be 4,096 N and 156,408 N (921 and 35,200 pounds force), respectively, for the low-forebay treatment and 7,007 $\mathrm{N}$ and 267,540 $\mathrm{N}$ (1,580 and 60,100 pounds force), respectively, for the high-forebay treatment. These estimated impact forces were calculated for impact at an elevation of $590 \mathrm{ft}$ MSL (approximately $7 \mathrm{ft}$ below the crest for a mass impacting a flat surface, so the 
actual forces would be less on a 115-degree incline, as found on the Foster Dam spillway. Also, the consequences of impact would vary for each fish, depending on the part of the body contacting the concrete - the area over which the impact force was applied and subsequent fish injury will depend on the orientation of the fish at contact with the spillway surface. Assuming a juvenile fish impacts on its snout, the total force can be estimated to be exerted on an area of approximately $4 \mathrm{~mm}^{2}$. The resultant pressure on this part of the body would be approximately 1,024 megapascals (MPa), which is a very high pressure and would almost certainly cause deformation of the fish's body and likely organ damage. If a larger area of the body impacted on the concrete structure (e.g., the side- $12 \mathrm{~cm}^{2}$ ), the impact forces would be spread over more area, resulting in a pressure of approximately 3.4 MPa over the area. Nonetheless, the differences in the mass of the Sensor Fish as compared with the mass of the steelhead used in the current evaluation would result in lower force at impact for Sensor Fish relative to either the juvenile or adult steelhead. This means that the absolute magnitudes of collision events observed in the Sensor Fish data may underestimate the forces that would be acting on the bodies of live fish. Further testing with Sensor Fish attached to adult fish may be warranted, including the examination of attachment methods and locations to attain more accurate impact data.

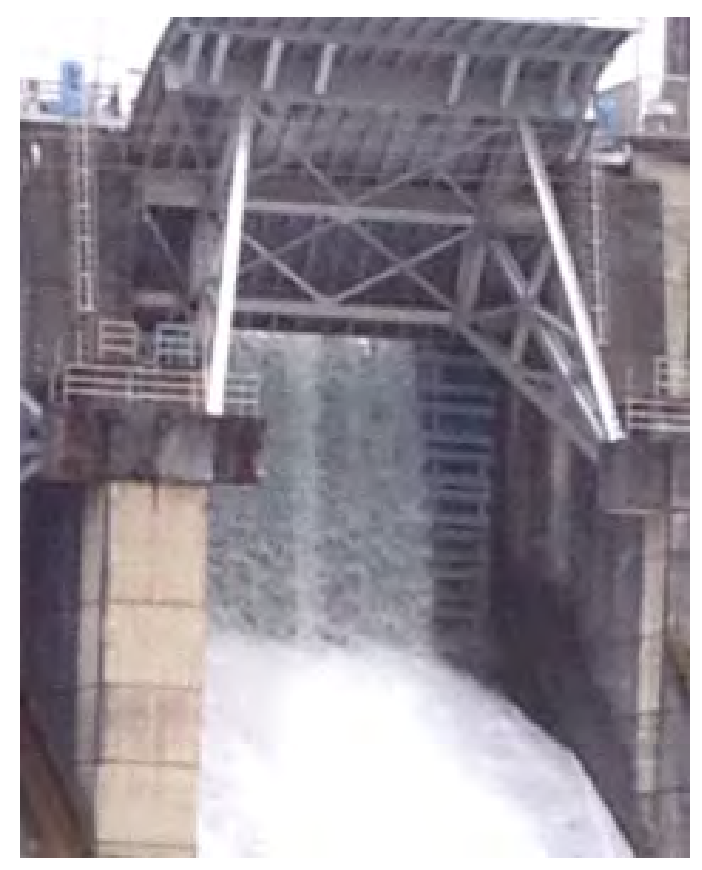

Figure 4.5. Flow over the spillway fish weir at Foster Dam during the high-forebay condition.

Čada et al. (2005) examined the effects of mechanical and fluid structures using a prototype pressuresensitive film (PSF) to roughly estimate the contact area and pressures at collision that might cause injuries to fish. PSF was attached to Sensor Fish, which were then injected into spill discharge at The Dalles and Bonneville dams on the Columbia River. These releases were concurrent with balloon tag survival tests of live fish. The sample sizes used for this prototype study were too small to draw conclusions about a direct relationship between the PSF impacts and fish survival or injury. Čada et al. confirmed the need for tissue damage studies to evaluate the effects of impact pressure and referenced food product studies that determined impact pressures to fish tissue, whereby muscle fibers are torn, are 40 to $48 \mathrm{MPa}$ (Jonsson at al. 2001; Sigurgisladottir et al. 1999), or 4,000 to 4,800 N/cm². Similar pressures were measured by Čada et al. (2005) on the PSF. 
Given that the adult steelhead could experience forces of as much as 267,540 N upon impact with the concrete chute, and that tissue damage has been quantified in refrigerated salmon fillets at 4,000 to $4,800 \mathrm{~N} / \mathrm{cm}^{2}$, the assumption that injury or bruising would occur is compelling. The forces are clearly available to cause injury; the variable is the surface area over which the force is distributed. This area is a random variable dependent upon the orientation of the fish at impact; any head exposure is likely more serious than tail impact.

\subsection{Penstock/Turbine Passage}

The Kaplan turbine at Foster Dam operates at 13,800 horsepower and $257 \mathrm{rpm}$. The runner diameter is $99.75 \mathrm{in}$., and the runner opening height is $42.5 \mathrm{in}$. Maximum discharge is approximately 3,200 cfs, and there are 6 blades and 20 wicket gates. Turbines at Foster Dam operate almost daily, based on Bonneville Power Administration load demands.

Exposure to changes in pressure, shear, turbulence, collisions, strike, cavitation, and grinding may occur during turbine passage and can cause injuries and mortality to fish. Fish are most vulnerable during passage through the wicket gates and runner, where they may collide on structure and be struck by runner blades, exposed to rapid changes in pressure, and exposed to turbulence and shear in the wake of wicket gates and runner blades. Sixty-two percent of the Sensor Fish experienced at least one significant event during turbine passage. For the low-forebay treatment, events were most frequent at the wicket gates; for the high-forebay treatment, events were more prevalent during runner passage. One Sensor Fish was broken in half during passage at the 9.0-MW treatment (high-forebay elevation) (Figure 4.6). Data was recovered from this unit showing normal passage to the runner, where the data stops abruptly (Figure 4.7). Sensor Fish experienced high loss rates during turbine passage. At the lower forebay treatment, more than 30\% were lost or damaged. Evidence of grinding or squeezing was evident in several Sensor Fish units, believed to be from being compressed between the turbine blade and wall (Figure 4.8). For context, the yield strength of polycarbonate is $70 \mathrm{MPa}$.

No significant events were observed during penstock passage. During turbine operations, Sensor Fish were more likely to experience a collision or strike event during passage at low operation (4.9/5.0 MW, 650 cfs) at the high-forebay level; all Sensor Fish experienced at least one event at this treatment. One minor (95.9 g) shear event occurred at the low-forebay treatment; otherwise all events were due to collision or strike. Shear events were observed through the runner and were more prevalent at the 4.9/5.0and 9.0-MW operations (650 and 1,150 cfs, respectively) during the high-forebay treatment. There was one event in the draft tube region, which was relatively minor (112 $\mathrm{g}$ ); this severity would most likely cause minor injury but not be fatal.

Events were most frequent at the wicket gates during the low-forebay tests; events during the highforebay treatment were more prevalent in the runner region. Events observed in the wicket gate region at high-forebay operations were of a much lower magnitude (averaging $121.1 \mathrm{~g}$ for all observed events) than those detected during the low-forebay operations, which averaged $145.7 \mathrm{~g}$. Conversely, events incurred within the runner region averaged $133.2 \mathrm{~g}$ for the high-forebay operations and $124.1 \mathrm{~g}$ for low-forebay operations. 


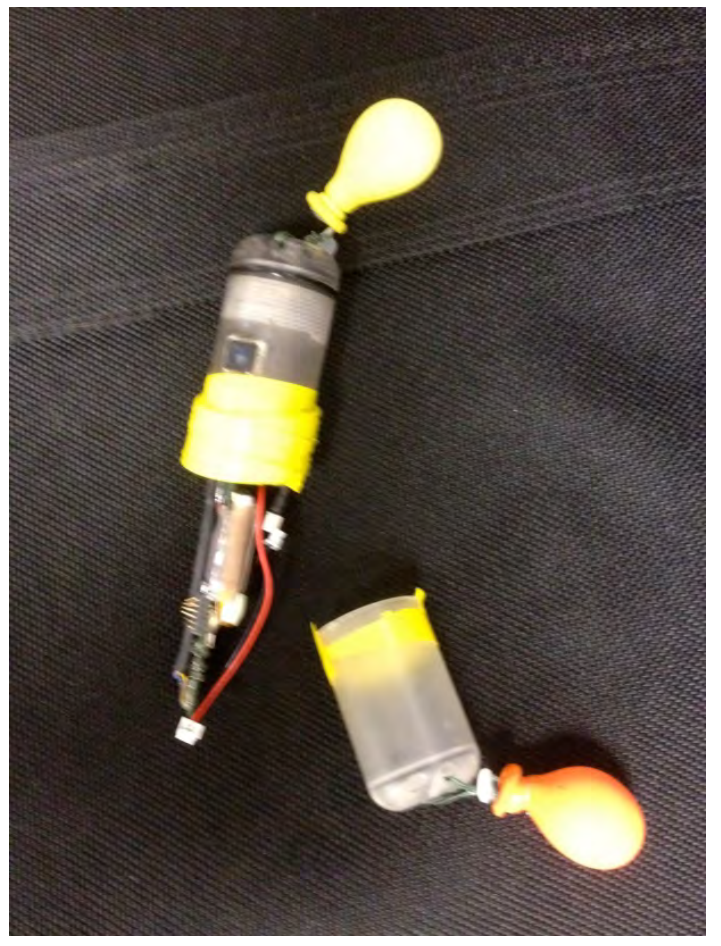

Figure 4.6. Sensor Fish in pieces following passage at the 9.0-MW, high-forebay condition.

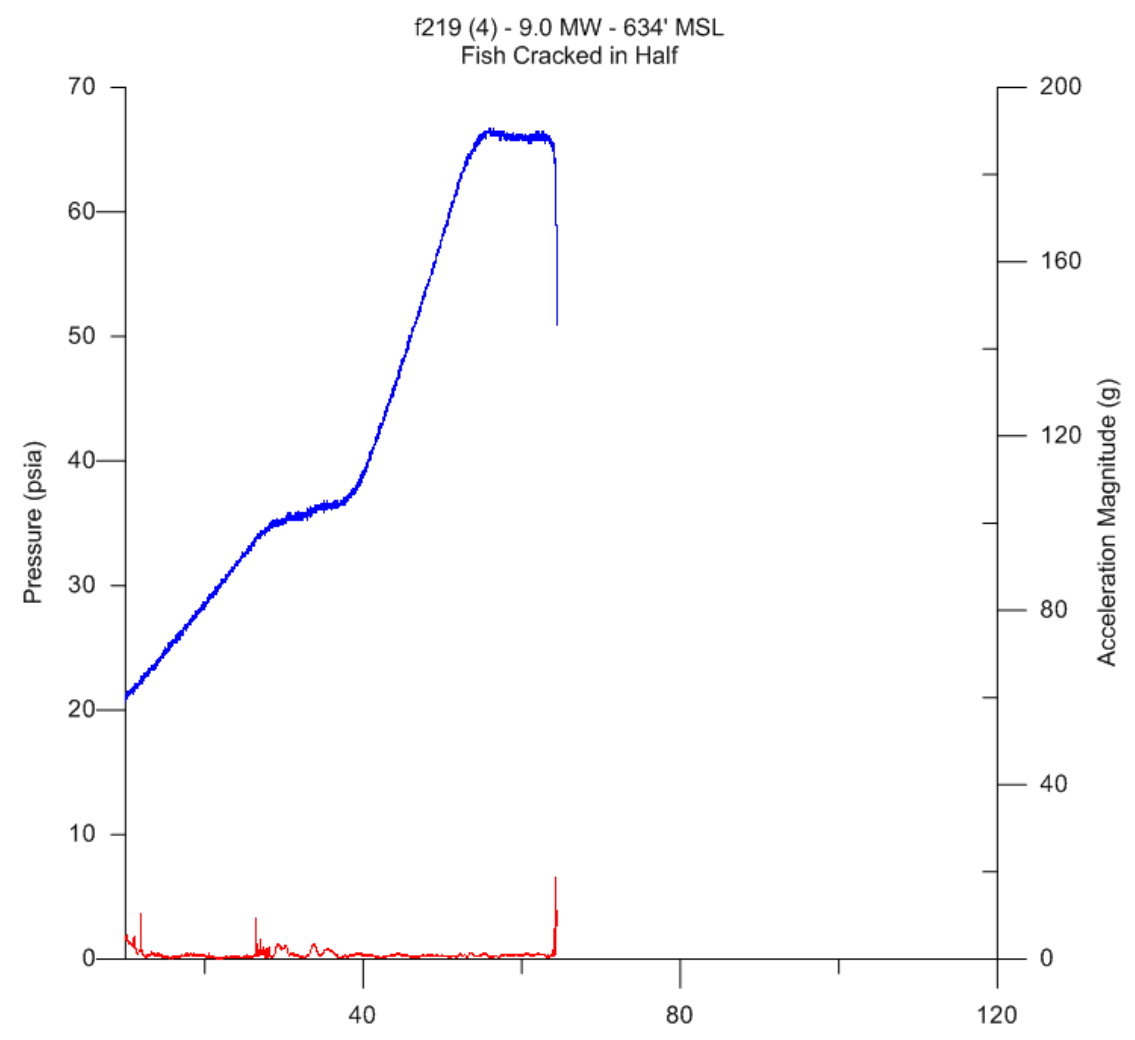

Figure 4.7. Data from cracked Sensor Fish stops at the runner. 


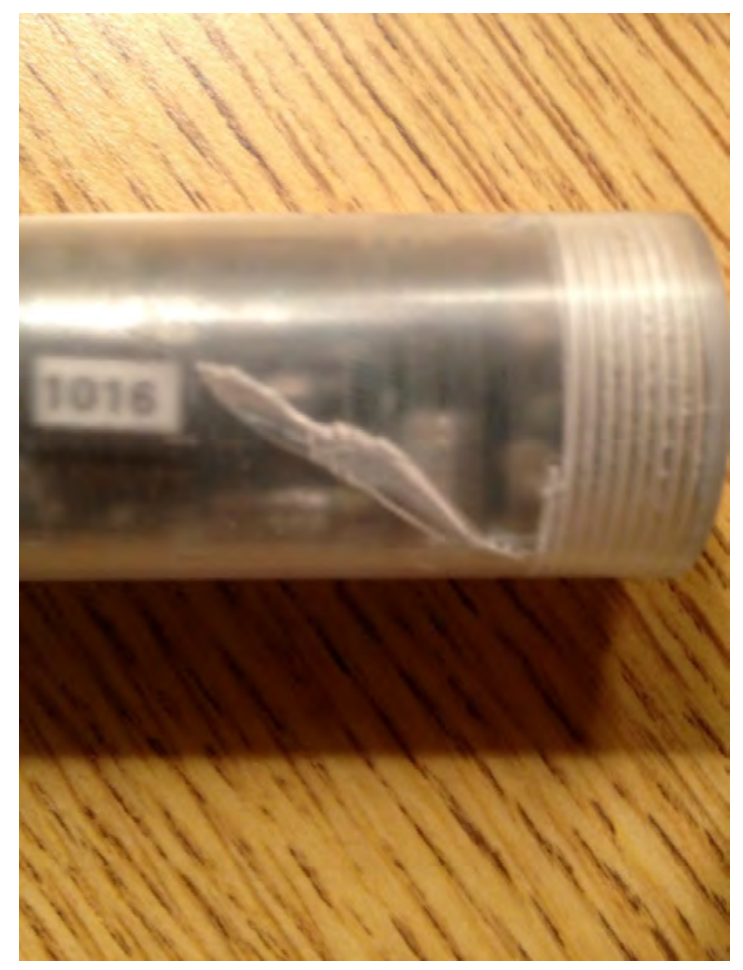

Figure 4.8. A stress crack in the Sensor Fish polycarbonate body following passage through turbine Unit 1.

Mean severe event magnitudes were greatest for the 4.9/5.0-MW treatment at the low-forebay level $(152.8 \mathrm{~g})$ and at the 6.5-MW treatment at the high-forebay level $(142.8 \mathrm{~g})$. Live fish that were severed or nearly severed or decapitated during the Foster Dam evaluation had the highest rates of decapitation/ severance at these treatment levels (Normandeau 2013).

The live balloon-tagged fish released into the turbine at Foster Dam were not pressure-acclimated. Because of the nature of the balloon-tagging process and handling requirements at placement into injection systems, test fish could not be released in a natural state of neutral buoyancy. Research has shown that physostomous juvenile salmon that are not neutrally buoyant when exposed to rapid decompression do not show the same barotrauma injury and mortality response as fish exposed when in a neutrally buoyant physiological condition (Brown et al. 2009; Carlson et al. 2010). Brown et al. (2012) quantified the probability of mortal injury to juvenile Chinook salmon exposed to simulated hydro-turbine passage. The evaluation determined that the acclimation pressure prior to turbine passage is one of two primary factors associated with the probability of mortal injury during turbine passage; the second factor is the exposure pressure nadir. The ratio between the acclimation pressure and the lowest exposure pressure experienced during passage has been directly associated with mortal injury (McKinstry et al. 2007; Brown et al. 2012). Brown et al. (2012) examined six covariates for their contribution to probability of mortal injury during turbine passage: 1) the natural log of the ratio of acclimation pressure to exposure pressure (LRP); 2) total dissolved gas (TDG); 3) condition factor; 4) rate of pressure change; 5) fish length; and 6) fish weight. They determined that LRP, condition factor, rate of pressure change, and interaction effects between TDG and condition factor and between LRP and TDG were significant 
predictors of mortal injury in juvenile Chinook salmon. Length and weight were not significant. The LRP was the single most influential factor in determining the possibility of mortal injury, as shown in Figure 4.9.

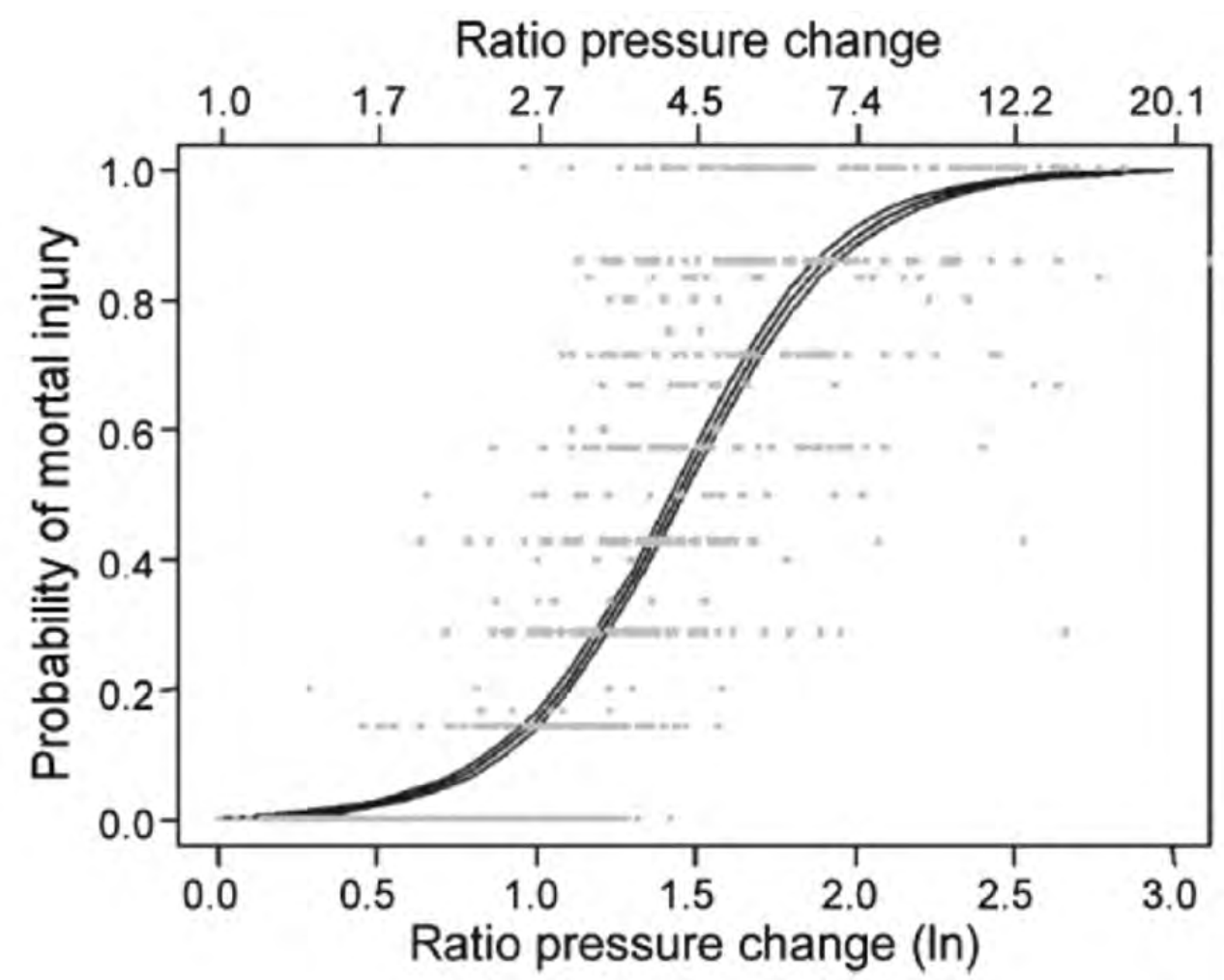

Figure 4.9. Probability of mortal injury from simulated turbine passage (Brown et al. 2012).

While steelhead were used in the Foster Dam study, similar results to those from the Brown et al. (2012) study on Chinook salmon might be expected because both species are physostomous. Study fish were not depth-acclimated, so assessment of barotrauma from exposure to changes in pressure during turbine passage is not possible. However, if one assumes the steelhead approach depth toward the entrance of the turbine penstock (at an elevation of $590 \mathrm{ft}$ MSL) at the low-forebay level (616 ft) to be 20 to $30 \mathrm{ft}$ and at the high-forebay level (634 ft) to be 30 to $40 \mathrm{ft}$, estimates of mortal injury can be calculated based on observed nadir pressures from the Sensor Fish. Table 4.1 presents the average nadir pressure during turbine passage for each treatment as measured by Sensor Fish, with the estimated acclimation pressures based on presumption of approach depths. The approach depths suggested are within the range of acclimation depths identified for salmonids (Pflugrath et al. 2012). The ratio of these and the natural log for each ratio are provided in Pflugrath et al. (2012) as well. The estimated ratio of observed nadir pressures (mean) and estimated acclimation pressures would be less than 2.2, and the associated natural $\log$ is 0.784 . Based on these assumptions, the probability of mortal injury due to barotrauma from passage through Foster turbines at the conditions tested would be approximately 10\%. Examining the worst-case scenario, based on the high-forebay 9.0-MW condition and a 40-ft approach depth, the lowest observed nadir was 13.86 psia, the ratio would be 2.26 , and the natural log would be 0.815 -less than $20 \%$ probability of mortal injury. 
Table 4.1. Sensor Fish nadir pressures; estimated depth acclimation pressures at approach and passage, ratio of acclimation to nadir, and natural log of the ratio for passage through turbine Unit 1 at Foster Dam, 2012.

\begin{tabular}{|c|c|c|c|c|c|c|c|c|c|c|}
\hline Condition & $\begin{array}{l}\text { Mean Nadir } \\
\text { Pressure } \\
\text { (psia) }\end{array}$ & $\begin{array}{c}20 \mathrm{ft} \\
\text { Approach } \\
\text { Depth (psia) }\end{array}$ & Ratio & $\begin{array}{l}\text { Natural } \\
\text { Log of } \\
\text { Ratio }\end{array}$ & $\begin{array}{c}30 \mathrm{ft} \\
\text { Approach } \\
\text { Depth (psia) }\end{array}$ & Ratio & $\begin{array}{l}\text { Natural } \\
\text { Log of } \\
\text { Ratio }\end{array}$ & $\begin{array}{c}40 \mathrm{ft} \\
\text { Approach } \\
\text { Depth (psia) }\end{array}$ & Ratio & $\begin{array}{c}\text { Natural } \\
\text { Log of } \\
\text { Ratio }\end{array}$ \\
\hline \multicolumn{11}{|c|}{ Low Forebay (616 ft) } \\
\hline 4.9/5.0 MW & 19.0 & 22.76 & 1.19 & 0.174 & 27.09 & 1.42 & 0.351 & NA & NA & NA \\
\hline $6.0 \mathrm{MW}$ & 16.31 & 22.76 & 1.38 & 0.322 & 27.09 & 1.65 & 0.501 & NA & NA & NA \\
\hline 7.0 MW & 15.07 & 22.76 & 1.53 & 0.425 & 27.09 & 1.82 & 0.599 & NA & NA & NA \\
\hline $6.5 \mathrm{MW}$ & 16.86 & 22.76 & 1.64 & 0.495 & 27.09 & 1.64 & 0.495 & 31.39 & 1.90 & 0.642 \\
\hline $9.0 \mathrm{MW}$ & 14.68 & 22.76 & 1.89 & 0.637 & 27.09 & 1.89 & 0.637 & 31.39 & 2.19 & 0.784 \\
\hline
\end{tabular}


Significant event occurrences as experienced by the Sensor Fish were more frequent for Foster Dam turbine passage than those observed during studies of Kaplan turbine passage at Columbia River dams. The percentage of Sensor fish with significant events at Foster (50\% at the lower forebay elevation and $75 \%$ at the higher forebay elevation) were two to three times higher than at Wanapum (22.4\% at Unit 8, 24\% at Unit 9), Bonneville (25.9\%), John Day (19.4\%), and Ice Harbor (28.6\%). The corresponding mean 48-hr mortality estimates at Foster (20\% at the lower forebay and $18.9 \%$ at the higher forebay) were three to five times higher than at Wanapum (3\% at Unit 8, 2.5\% at Unit 9), Bonneville (3.9\%), John Day (5.3\%), and Ice Harbor (3.9\%) (Table 4.2). Comparison of these live-fish mean mortalities and the percentage of Sensor Fish with significant events indicate there is a linear relationship (Figure 4.10).

Table 4.2. Average live-fish mortality and percentage of Sensor Fish experiencing a significant event during Kaplan turbine passage at USACE hydropower projects.

\begin{tabular}{llccc}
\hline Project & Turbine & $\begin{array}{c}\text { Approximate } \\
\text { Head (ft) }\end{array}$ & $\begin{array}{c}\text { Mean } \\
\text { Mortality }\end{array}$ & $\begin{array}{c}\text { Percentage with } \\
\text { Significant } \\
\text { Event }\end{array}$ \\
\hline Wanapum & AHTS & 77 & 0.030 & 0.224 \\
& Kaplan & 77 & 0.025 & 0.240 \\
Bonneville & Kaplan & 59 & 0.039 & 0.259 \\
John Day & Kaplan & 103 & 0.053 & 0.194 \\
Ice Harbor & Kaplan & 99 & 0.039 & 0.286 \\
Foster & Kaplan & 107 & 0.189 & 0.500 \\
& Kaplan & 86 & 0.200 & 0.750 \\
\hline
\end{tabular}



Figure 4.10. Fit of a linear model between live-fish estimated 48-hr mortality and the percentage of Sensor Fish experiencing a significant event at Columbia and Snake River dams and Foster Dam. 
The lowest pressure (nadir) that occurs in the water path from the penstock entrance through draft tube exit occurs on the underside of turbine runner blades, which is called the suction side of the turbine runner. The mean of nadir pressures observed for Sensor Fish passage through the Kaplan turbine at Foster Dam for all operating conditions was approximately 17.24 psia; pressures were lowest for the highforebay, high-power (9.0-MW) treatment (ranging from 13.7 to 15.08 psia; mean value 14.68 psia). The observed nadir values for the Foster Dam turbine are comparable to those observed for Kaplan turbines installed in the mainstem Columbia and Snake river dams, ranging from approximately 14 to 21 psia. Average nadir pressures measured at the Kaplan turbines on the mainstem rivers ranged from approximately 13 to 27 psia, depending upon variables such as discharge and trajectory through the turbine runner (Carlson and Duncan 2002; Dauble et al. 2007; Carlson et al. 2008). Table 4.3 shows nadir values obtained at low-head dams on the Columbia and Snake rivers, along with those observed during the Foster Dam study.

Table 4.3. Pressure nadirs observed in Sensor Fish data during turbine passage at USACE hydropower projects.

\begin{tabular}{lccccc}
\hline Project & Flow $(\mathrm{kcfs})$ & $\begin{array}{c}\text { Mean Head } \\
(\mathrm{ft})\end{array}$ & $\begin{array}{c}\text { Mean Pressure } \\
\text { Nadir (psia) }\end{array}$ & $\begin{array}{c}\text { Maximum Pressure } \\
\text { Nadir (psia) }\end{array}$ & $\begin{array}{c}\text { Minimum Pressure } \\
\text { Nadir (psia) }\end{array}$ \\
\hline Ice Harbor & 8.3 & 98.9 & 19.60 & 23.28 & 14.38 \\
& 13.1 & 98.4 & 13.19 & 20.35 & 0.45 \\
& 13.45 & 99.1 & 15.00 & 19.48 & 7.13 \\
John Day & 14.1 & 98.6 & 14.99 & 19.54 & 6.33 \\
& 11.6 & 103.0 & 27.05 & 30.55 & 23.1 \\
& 19.9 & 102.6 & 19.07 & 23.38 & 9.22 \\
& 16.5 & 103.3 & 22.53 & 27.02 & 15.99 \\
Bonneville & 20.3 & 102.6 & 13.87 & 22.87 & -0.26 \\
& 11.1 & 45.4 & 20.30 & 23.75 & 13.5 \\
& 15.8 & 45.5 & 16.27 & 20.7 & 8.69 \\
Foster & 16.9 & 55.8 & 18.45 & 21.95 & 11.65 \\
& $\mathbf{0 . 5 5}$ & $\mathbf{8 6 . 7}$ & $\mathbf{2 0 . 5 9}$ & $\mathbf{2 2 . 2 6}$ & $\mathbf{1 9 . 3 2}$ \\
& $\mathbf{0 . 6 5}$ & $\mathbf{1 0 7 . 5}$ & $\mathbf{1 7 . 5 6}$ & $\mathbf{1 9 . 2 4}$ & $\mathbf{1 6 . 5 9}$ \\
& $\mathbf{0 . 8 0}$ & $\mathbf{8 6 . 1}$ & $\mathbf{1 9 . 0 0}$ & $\mathbf{1 9 . 9 6}$ & $\mathbf{1 7 . 2 7}$ \\
& $\mathbf{0 . 8 2}$ & $\mathbf{1 0 7 . 5}$ & $\mathbf{1 6 . 8 6}$ & $\mathbf{1 8 . 7 7}$ & $\mathbf{1 5 . 6 9}$ \\
& $\mathbf{0 . 9 8}$ & $\mathbf{8 5 . 7}$ & $\mathbf{1 6 . 3 1}$ & $\mathbf{1 8 . 8 5}$ & $\mathbf{1 3 . 7 4}$ \\
& $\mathbf{1 . 1 5}$ & $\mathbf{8 6 . 0}$ & $\mathbf{1 5 . 0 7}$ & $\mathbf{1 7 . 4 2}$ & $\mathbf{1 3 . 5 7}$ \\
\hline
\end{tabular}

Using Sensor Fish, the mean rate of change in pressure for all treatments through the Foster Dam turbine was $-553.3 \mathrm{psia} / \mathrm{s}$, observed at approach to the nadir. The mean rate of change in pressure was greatest for passage during the high-forebay treatment at the 6.5-MW operating condition (-599.6 psia/s); lowest rate of change was observed at the low-forebay, 2.8/3.0-MW treatment ( $-412.2 \mathrm{psia} / \mathrm{s})$. These values are much higher than those observed for passage through Kaplan turbines at mainstem Columbia and Snake river projects, which varied between -125 to -413 psia/s (Table 4.4) (Carlson et al. 2008).

Figure 4.11 is a scatter plot of the pressure rate of change versus the pressure nadir for John Day, Bonneville, Ice Harbor, and Foster dams. The Foster Dam results generally fall mid-range within overall nadir values, while the associated pressure rates of change are somewhat higher than those acquired from Columbia River dams. 
Table 4.4. Pressure rates of change observed from Sensor Fish turbine passage at USACE hydropower projects.

\begin{tabular}{|c|c|c|c|c|c|}
\hline Project & $\begin{array}{l}\text { Flow } \\
(\mathrm{kcfs})\end{array}$ & $\begin{array}{c}\text { Approximate Head } \\
(\mathrm{ft})\end{array}$ & $\begin{array}{c}\text { Mean Pressure } \\
\text { Rate of Change } \\
(\mathrm{psia} / \mathrm{s})\end{array}$ & $\begin{array}{c}\text { Maximum Pressure } \\
\text { Rate of Change } \\
\text { (psia/s) }\end{array}$ & $\begin{array}{c}\text { Minimum Pressure } \\
\text { Rate of Change } \\
\text { (psia/s) }\end{array}$ \\
\hline \multirow[t]{4}{*}{ Ice Harbor } & 8.3 & 98.9 & -413.4 & -686.4 & -238.6 \\
\hline & 13.1 & 98.4 & -318.1 & -661.6 & -127 \\
\hline & 13.45 & 99.1 & -336.3 & -838.8 & -113.4 \\
\hline & 14.1 & 98.6 & -374.4 & -637.8 & -193.2 \\
\hline \multirow[t]{4}{*}{ John Day } & 11.6 & 103.0 & -320.1 & -572.6 & -176 \\
\hline & 16.5 & 102.6 & -351.1 & -649 & -227.2 \\
\hline & 19.9 & 103.3 & -304.1 & -525.6 & -175.4 \\
\hline & 20.3 & 102.6 & -373 & -604.2 & -241.2 \\
\hline \multirow[t]{3}{*}{ Bonneville } & 11.1 & 45.4 & -139.7 & -297.2 & -22 \\
\hline & 15.8 & 45.5 & -184.9 & -384.8 & -105.4 \\
\hline & 16.9 & 55.8 & -125.8 & -339.4 & -40 \\
\hline \multirow[t]{7}{*}{ Foster } & 0.55 & 86.7 & -412.2 & -512.4 & -309.1 \\
\hline & 0.65 & 107.5 & -567.8 & -691.0 & -323.4 \\
\hline & 0.80 & 86.1 & -543.7 & -707.9 & -451.0 \\
\hline & 0.82 & 107.5 & -599.6 & -707.0 & -380.8 \\
\hline & 0.98 & 85.7 & -578.5 & -624.4 & -455.8 \\
\hline & 1.15 & 86.0 & -579.2 & -638.4 & -469.2 \\
\hline & 1.15 & 107.1 & -575.2 & -680 & -429.9 \\
\hline
\end{tabular}

The probability of a fish being struck by a turbine runner blade during passage through the Kaplan turbine at Foster Dam was estimated as a function of turbine design, operation, fish length, and orientation during runner passage. The method used by Deng et al. (2007b) was used to estimate the probability of blade strike during runner passage.

The distribution of orientation of fish at runner passage was estimated to be uniform over the tilt range of 0 to 45 degrees off the tangential velocity vector (Deng et al. 2007b). Simulations to estimate the probability of strike and of injury were run for all discharges used in the live-fish and Sensor Fish studies. The simulation results are presented in Table 4.5. As is known to be the case, the probability of strike or other contact by a turbine blade is higher than is the probability of injury (Turnpenny et al. 2000). The injury rate was estimated from strike rate by applying the mutilation ratio derived by Turnpenny et al. (2000). Fish length was modeled for the strike simulation using a normal distribution with the mean $(213 \mathrm{~mm})$ and standard distribution $(17.59 \mathrm{~mm})$ of the test fish used in the live-fish portion of the Foster Dam turbine passage study.

The probability of strike estimated using the blade strike model and the occurrence of significant events observed with Sensor Fish were very similar for four of the seven test conditions. It is not clear from analysis conducted to date what the causes were for the differences between these estimates that occurred at the other flow conditions where, in all cases, the frequency of significant events was much higher than the blade strike probabilities. It could be that flow conditions at these operations resulted in a much higher probability of occurrence of high turbulence and resulting shear exposure, which would be detected by the sensor and identified in the analysis as a severe event. The injury rates of balloon-tagged fish compared with injury probability from model results are shown in Figure 4.12. The frequency of 
occurrence of injury observed for balloon-tagged fish and the probability of injury estimated using the blade strike model were not statistically different for any of the operations tested. The mean probabilities of injury were estimated by multiplying model probability of strike estimates by a mutilation ratio to account for the fact that not all fish struck by a turbine blade are injured.

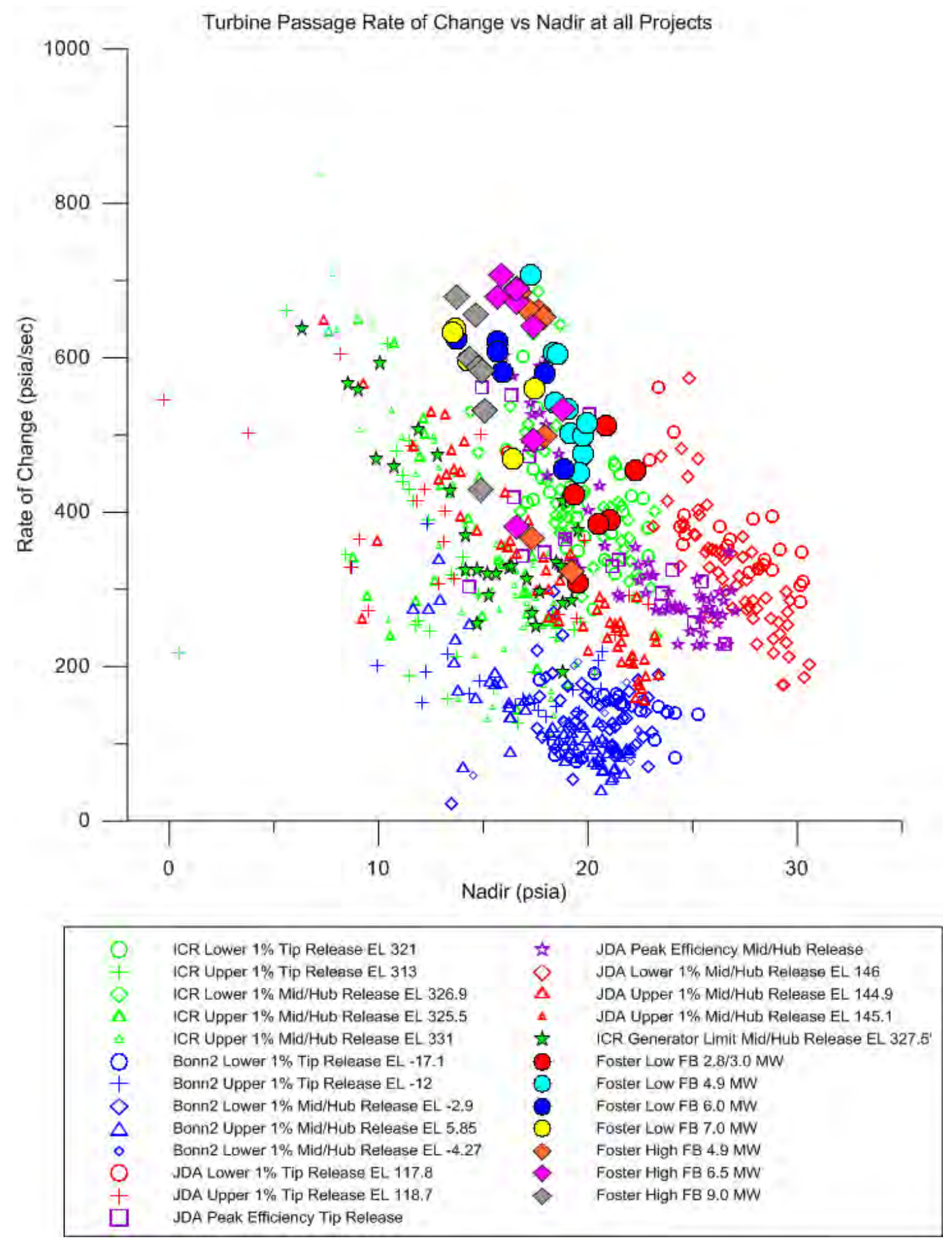

Figure 4.11. Turbine runner passage pressure rate of change by nadir pressure for Foster, John Day, Bonneville, and Ice Harbor dams. 
Table 4.5. Probability of strike and injury for fish passing through Foster Dam turbine Unit 1.

\begin{tabular}{|c|c|c|c|c|c|c|c|c|c|c|c|c|}
\hline & \multirow[b]{2}{*}{$\begin{array}{c}\text { Discharge } \\
\text { (cfs) }\end{array}$} & \multirow{2}{*}{$\begin{array}{c}\text { Forebay } \\
\text { Level } \\
\text { (ft) }\end{array}$} & \multirow{2}{*}{$\begin{array}{c}\text { Wicket } \\
\text { Gate } \\
\% \\
\text { Open }\end{array}$} & \multirow{2}{*}{$\begin{array}{l}\text { Runner } \\
\text { Blade } \\
\text { Angle } \\
\text { (deg) }\end{array}$} & \multicolumn{2}{|c|}{$\begin{array}{c}\text { Probability of } \\
\text { Strike }\end{array}$} & \multicolumn{2}{|c|}{$\begin{array}{l}\text { Probability of } \\
\text { Injury }\end{array}$} & \multicolumn{2}{|c|}{ Live Fish } & \multicolumn{2}{|c|}{ Sensor Fish } \\
\hline & & & & & Mean & SD & Mean & SD & $\begin{array}{l}\text { Injury } \\
\text { Rate }\end{array}$ & SD & $\begin{array}{c}\text { Damage } \\
\text { Rate }\end{array}$ & $\begin{array}{l}\text { With } \\
\text { Event }\end{array}$ \\
\hline \multirow{4}{*}{$\begin{array}{l}\text { Low- } \\
\text { Forebay } \\
\text { Elevation }\end{array}$} & 550 & 616 & 35 & flat & 0.577 & 0.371 & 0.228 & 0.189 & 0.228 & 0.440 & 0 & 0.5 \\
\hline & 800 & 616 & 53 & 1 & 0.43 & 0.277 & 0.17 & 0.141 & 0.254 & 0.448 & 0.15 & 0.44 \\
\hline & 970 & 616 & 60 & 4 & 0.361 & 0.23 & 0.143 & 0.117 & 0.285 & 0.478 & 0.30 & 0.67 \\
\hline & 1150 & 616 & 67 & 7 & 0.308 & 0.196 & 0.122 & 0.1 & 0.181 & 0.394 & 0.44 & 0.4 \\
\hline \multirow{3}{*}{$\begin{array}{l}\text { High- } \\
\text { Forebay } \\
\text { Elevation }\end{array}$} & 730 & 634 & 40 & flat & 0.449 & 0.289 & 0.178 & 0.147 & 0.193 & 0.405 & 0 & 1 \\
\hline & 820 & 634 & 49 & 2 & 0.415 & 0.267 & 0.164 & 0.136 & 0.261 & 0.453 & 0.09 & 0.38 \\
\hline & 1422 & 634 & 58 & 8 & 0.244 & 0.158 & 0.096 & 0.08 & 0.207 & 0.408 & 0.11 & 0.88 \\
\hline
\end{tabular}

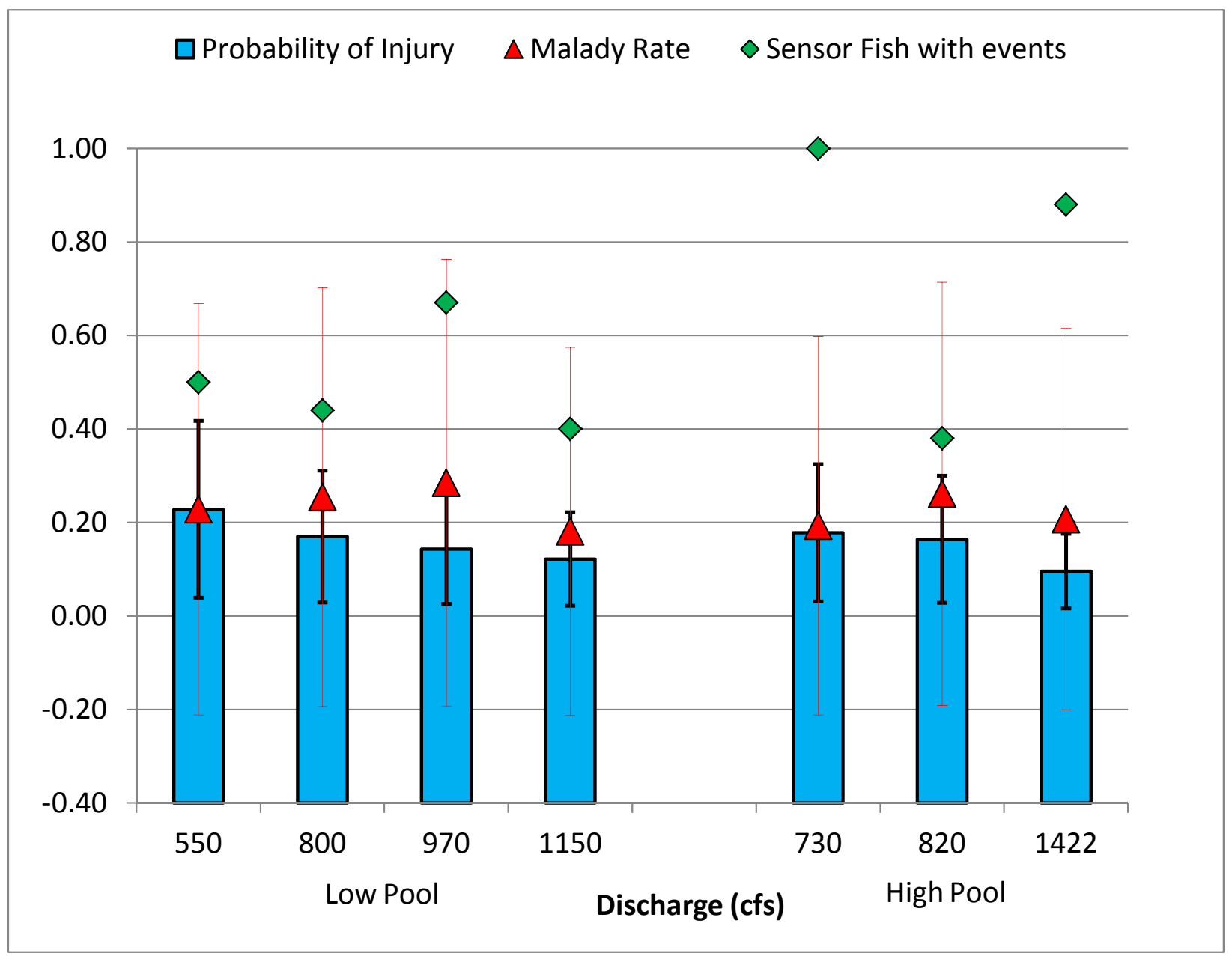

Figure 4.12. Probability of injury from simulation model and actual live-fish injury estimates. Error bars represent standard deviation. 


\subsection{Conclusions}

Low discharge flows over the spillway fish weir at Foster Dam resulted in a shallow depth of flow and a poorly formed discharge jet, regardless of forebay elevation tested. All Sensor Fish passing over the weir experienced at least one significant event, as there was no water "cushioning" effect; the majority had multiple events as they tumbled down the spillway. The trajectory of the flow discharge at impact was at an approximate 115-degree incline; adjusting the discharge jet impact angle on the spillway chute would allow fish to be retained in the jet, away from the spillway surface. Magnitudes observed at impact with the spillway were highest for low-forebay (616-ft MSL) passage, although the distance to impact was greater for the high-forebay (634-ft MSL) treatment—an approximately 18-ft difference. This finding was likely due to the depth of flow. Shear events were observed only during the high-forebay treatment, and all occurred at chute impact. All other significant events were collisions, regardless of treatment condition.

Sensor Fish velocity prior to impact was as high as 40 and $52 \mathrm{ft} / \mathrm{s}$ for the low- and high-forebay levels, respectively, and impact force was calculated to be 1,862 and 3,185 N, respectively. The velocities and impacts of the live fish during passage would be much greater than those of the Sensor Fish, due to their larger mass. In fact, most of the injuries observed on the spillway weir-passed juvenile salmon were attributed to the shallow depth of the weir jet and the angle at which the jet contacted the spillway chute (Normandeau 2013).

Twenty-three percent of the Sensor Fish passing over the spillway weir at the high-forebay level were damaged following passage through the juvenile fish pipe; only $5 \%$ were damaged following passage at the low-forebay level.

Based on studies at Columbia and Snake River dams, restoring the discharge jet focus, depth, and trajectory would help to contribute to a safer route of passage over the spillway fish weir at Foster Dam than what was tested during the current study.

Sensor Fish experienced high loss rates during the turbine study at Foster Dam-more than 22\% of the units were either lost or damaged, most at the low-forebay treatment. Evidence of grinding or squeezing was observed, assumed to be due to the units being compressed between the turbine blade and wall during runner passage.

Collision or strike events were most prevalent during turbine passage; shear events occurred mainly during the high-forebay treatment in the runner region. Events were most frequent at the wicket gates during the low-forebay tests; events during the high-forebay treatment were more prevalent in the runner region. Significant events of the highest magnitudes were generally slightly higher during the lowforebay treatment than during high-forebay passage. Significant event occurrences as experienced by the Sensor Fish were more frequent for Foster Dam turbine passage than those observed during studies of Kaplan turbine passage at Columbia River dams. The runner speed, $257 \mathrm{rpm}$, its diameter and six blades, and the velocity at the periphery of the runner (approximately $224 \mathrm{fps}$ ) contributed to the higher number of events. Mean severe event magnitudes were greatest for the 4.9/5.0-MW treatment at the low-forebay level $(152.8 \mathrm{~g})$ and at the 6.5-MW treatment at the high-forebay level $(142.8 \mathrm{~g})$. 
The average turbine pressure nadirs were comparable to those observed for Kaplan turbines installed in the mainstem Snake and Columbia river dams. However, all the lowest nadir values were greater than 13.56 psia, generally higher than most minimum values observed at Kaplan turbines at other Snake and Columbia River projects. Lowest nadirs were observed for the high-forebay 9.0-MW treatment, averaging 14.68 psia; highest was 20.59 psia, during low operation (2.8/3.0 MW) and low-forebay elevation.

A simulation model was used to estimate the probability of injury due to blade strike. These estimates were not statistically different from the observations of frequency of occurrence of injury for balloon-tagged fish. Differences observed between the probability of blade strike estimated using the model and the occurrence of severe events observed using Sensor Fish suggest that at a few of the operations tested, flow conditions resulted in a higher occurrence of severe turbulence and shear that increased the rate of occurrence of severe events detected.

Comparison of Sensor Fish results for the two passage routes tested at Foster Dam during spring 2012 indicate that Sensor Fish passing over the weir experienced higher event magnitudes than those passing through the turbine, as most experienced significant events upon impact with the spillway chute. Increasing the depth of flow would likely enhance passage conditions by providing an improved discharge jet as well as a cushioning effect for fish and Sensor Fish. Possible changes to the spillway weir design should also be investigated to improve the route's safety at both pool levels.

Significant event occurrences as experienced by the Sensor Fish were two to three times more frequent for Foster Dam turbine passage than those observed during studies of Kaplan turbine passage at Columbia and Snake river dams. The corresponding mortality and injury rates for the live turbine-passed fish were also two to three times higher at Foster Dam. 


\subsection{References}

Brown RS, TJ Carlson, AE Welch, JR Stephenson, CS Abernethy, BD Ebberts, MJ Langeslay, ML Ahmann, DH Feil, JR Skalski, and RL Townsend. 2009. "Assessment of Barotrauma from Rapid Decompression of Depth-Acclimated Juvenile Chinook Salmon Bearing Radiotelemetry Transmitters.” Transactions of the American Fisheries Society 138:1285-1301.

Brown RS, TJ Carlson, AJ Gingerich, JR Stephenson, BD Pflugrath, and AE Welch. 2012. "Quantifying Mortal Injury of Juvenile Chinook Salmon Exposed to Simulated Hydro-Turbine Passage.” Transactions of the American Fisheries Society 141:147-157.

Čada G, J Smith, and J Busey. 2005. "Use of Pressure-Sensitive Film to Quantify Sources of Injury to Fish.” North American Journal of Fisheries Management 25:57-66.

Carlson TJ and JP Duncan. 2002. Characterization of the McNary Dam Turbine Fish Passage Environment, April 2002. PNWD-3310, Battelle-Pacific Northwest Division, Richland, Washington.

Carlson TJ and JP Duncan. 2009. Evaluation of Fish Passage Conditions for a Top Spillway Weir at John Day Dam Using the Sensor Fish. PNWD-4023, Battelle-Pacific Northwest Division, Richland, Washington.

Carlson TJ, JP Duncan, and Z Deng. 2008. Data Overview for Sensor Fish Samples Acquired at Ice Harbor, John Day, and Bonneville II Dams in 2005, 2006, and 2007. PNNL-17398, Pacific Northwest National Laboratory, Richland, Washington.

Carlson TJ, RS Brown, JR Stephenson, AJ Gingerich, BD Pflugrath, AH Colotelo, AE Welch, PL Benjamin, JR Skalski, AG Seaburg, and RL Townsend. 2010. Assessment of Barotrauma in Untagged and Tagged Juvenile Chinook Salmon Exposed to Simulated Hydro-Turbine Passage. PNNL-19625, Pacific Northwest National Laboratory, Richland, Washington.

Dauble, DD, Z Deng, MC Richmond, RA Moursund, TJ Carlson, CL Rakowski, and JP Duncan. 2007. Biological Assessment of the Advanced Turbine Design at Wanapum Dam, 2005. PNNL-16682, Pacific Northwest National Laboratory, Richland, Washington.

Deng Z, TJ Carlson, JP Duncan, and MC Richmond. 2007a. “Applications of the Sensor Fish Technology.” Hydro Review 26(5):34-41.

Deng Z, TJ Carlson, GR Ploskey, MC Richmond, and DD Dauble. 2007b. "Evaluation of Blade-Strike Models for Estimating the Biological Performance of Kaplan Turbines.” Ecological Modeling 208:165-176.

Heisey PG, D Mathur, and T Rineer. 1992. "A Reliable Tag-Recapture Technique for Estimating Turbine Passage Survival: Application to Young-of-the-Year American Shad (Alosa sapidissima).” Canadian Journal of Fisheries and Aquatic Sciences 49:1826-1834. 
Jonsson A, S Sigurgisladottir, H Hafsteinsson, and K Kristbergsson. 2001. "Textural Properties of Raw Atlantic Salmon (Salmo salar) fillets measured by Different Methods in Comparison to Expressible Moisture.” Aquiculture Nutrition 7:81-89.

McKinstry CA, TJ Carlson, and RS Brown. 2007. Derivation of Mortal Injury Metric for Studies of Rapid Decompression of Depth-Acclimated Physostomous Fish. PNNL-17080, Pacific Northwest National Laboratory, Richland, Washington.

Normandeau Associates, Inc. 2013. Estimates of Direct Effects of Steelhead Salmon During Downstream Passage Through a Turbine and Weir at Foster Dam, Oregon. Prepared for the U.S. Army Corps of Engineers, Portland District, Portland, Oregon.

Normandeau, JR Skalski, and R Townsend. 2008. Direct Survival and Injury Evaluation of Juvenile Chinook Salmon Passing John Day Dam Spillway with and without a Top Spillway Weir (TSW).

Normandeau Associates, Inc., Drumore, Pennsylvania.

Pflugrath BD, RS Brown, and TJ Carlson. 2012. "Maximum Neutral Buoyancy Depth of Juvenile Chinook Salmon: Implications for Survival during Hydroturbine Passage.” Transactions of the American Fisheries Society 141(2):520-525.

Sigurgisladottir S, H Hafsteinsson, A Jonsson, O Lie, R Nortvedt, M Thomassen, and O Torrissen. 1999. "Textural Properties of Raw Salmon Fillets as Related to Sampling Method." Journal of Food Science 64(1):99-104.

Turnpenny, AWH, S Clough, KP Hanson, R Ramsay, and D McEwan. 2000. Risk Assessment for Fish Passage through Small, Low-Head Turbines. ETSU H/06/00054/REP, Energy Technical Support Unit, Harwell, United Kingdom. 


\section{Appendix A}

\section{Field Log Data Sheets}

Appendix A, found on the attached CD, contains field log data sheets showing dam operating conditions, release locations and deployment and recovery times for each Sensor Fish release, and other project information for the study period. 


\section{Appendix B}

\section{Data Summary Tables for Each Sensor Fish Release}

Summary tables for each Sensor Fish release may be found on the attached CD. 


\section{Appendix C}

\section{Pressure and Acceleration Magnitude Time Histories for Each Sensor Fish Release}

Figures showing the pressure and acceleration magnitude time histories for each Sensor Fish release may be found on the attached CD. 


\section{Appendix D}

\section{Pressure and Angular Rate-of-Change Time Histories of Each Sensor Fish Release}

Figures showing the pressure and angular rate-of-change time histories for each Sensor Fish release may be found on the attached CD. 


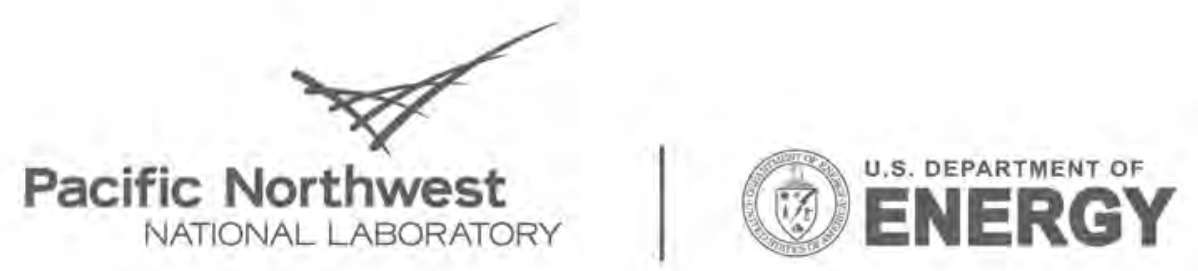

Proudly Operated by Battelle Since 1965

902 Battelle Boulevard

P.O. Box 999

Richland, WA 99352

1-888-375-PNNL (7665)

www.pnl.gov 
Appendix A

Field Log Data Sheets 


\begin{tabular}{|c|c|c|c|c|c|c|c|c|c|c|}
\hline Test Date & Location & Test Condition & $\begin{array}{c}\text { Fish } \\
\text { ID }\end{array}$ & $\begin{array}{c}\text { Tag } \\
\text { Number }\end{array}$ & $\begin{array}{l}\text { Deployment } \\
\text { Time }\end{array}$ & $\begin{array}{l}\text { Recovery } \\
\text { Time }\end{array}$ & File Name & $\begin{array}{l}\text { Barometric } \\
\text { Pressure }\end{array}$ & & Notes \\
\hline \multicolumn{11}{|c|}{ Low Forebay - 616 ft MSL } \\
\hline \multirow[t]{3}{*}{$5 / 2 / 2012$} & Unit 1 & $2.8 \mathrm{MW}-540 \mathrm{cfs}$ & 115 & 9271 & 1445 & 1451 & f115_L_1a & 29.12 & 14.30 & No runner data - induction pipe delay \\
\hline & & Low FB: $\sim 616 \mathrm{ft}$ & 114 & 9471 & 1547 & 1553 & f114_L_2 & 29.11 & 14.30 & \\
\hline & & & 635 & 9173 & 1649 & 1653 & f635_L_3 & 29.10 & 14.29 & \\
\hline \multirow[t]{7}{*}{$5 / 3 / 2012$} & Unit 1 & 4.9/5.0 MW - $800 \mathrm{cfs}$ & 115 & 9271 & 1138 & 1150 & F115_L_1 & 28.92 & 14.20 & \\
\hline & & Low FB: $\sim 616 \mathrm{ft}$ & 114 & 9471 & 1239 & 1244 & & 28.95 & 14.22 & Dead \\
\hline & & & 635 & 9173 & 1326 & lost & & 28.99 & 14.24 & bottom of tailrace \\
\hline & & & 1112 & 9480 & 1445 & lost & & 29.07 & & no signal \\
\hline & & & 1110 & 9554 & 1544 & 1549 & f1110_L_2 & $985.4 \mathrm{hPA}$ & 14.29 & \\
\hline & & & 664 & 9340 & 1629 & 1634 & F664_L_3 & 29.10 & 14.29 & \\
\hline & & & 1002 & 9491 & 1657 & 1702 & f1002_L_4 & 29.12 & 14.30 & bad acceleration \\
\hline \multirow[t]{10}{*}{$5 / 4 / 2012$} & Unit 1 & $6.0 \mathrm{MW}-980 \mathrm{cfs}$ & 1011 & 9194 & 835 & 840 & f1011_m_1 & 29.41 & 14.44 & \\
\hline & & Low FB: $\sim 616 \mathrm{ft}$ & 1006 & 9601 & 935 & 940 & & 29.41 & 14.44 & $\begin{array}{l}\text { broken inside - data to } \sim \text { runner } \\
\text { position }\end{array}$ \\
\hline & & & 900 & 9890 & 1003 & 1006 & f900_m_2 & 29.42 & 14.45 & \\
\hline & & & 1014 & 9531 & 1034 & 1045 & & 29.42 & 14.45 & cracked - water infiltrated \\
\hline & & & 901 & 9183 & 1109 & 1130 & f901_m_4 & 29.44 & 14.46 & \\
\hline & & & 900 & 9890 & 1152 & 1154 & f900_m_5 & 29.44 & 14.46 & \\
\hline & & & 1015 & 9471 & 1229 & 1234 & f1015_m_3 & 29.44 & 14.46 & \\
\hline & & & 1015 & 9471 & 1438 & 1440 & f1015_m_6 & 29.48 & 14.48 & \\
\hline & & & 901 & 9183 & 1509 & lost & & 29.48 & 14.48 & 2 balloons sheared off \\
\hline & & & 900 & 9890 & 1544 & 1547 & & 29.50 & 14.49 & water inside - data to $\sim$ runner position \\
\hline \multirow[t]{9}{*}{ 5/5/2012 } & Unit 1 & 7.0 MW - $1150 \mathrm{cfs}$ & 1016 & 9601 & 855 & 859 & & 29.75 & 14.61 & $\begin{array}{l}\text { yellow balloon only - cracked, water } \\
\text { filled }\end{array}$ \\
\hline & & Low FB: $\sim 616 \mathrm{ft}$ & 1011 & 9194 & 1009 & 1017 & f1011_H_1 & 29.73 & 14.60 & \\
\hline & & & 1015 & 9471 & 1103 & 1107 & f1015_H_2 & 29.73 & 14.60 & Acceleration and pressure --defective \\
\hline & & & 900 & 9491 & 1149 & 1152 & & 29.72 & 14.60 & DEAD \\
\hline & & & 1011 & 9194 & 1308 & 1317 & f1011_H_3 & 29.70 & 14.59 & \\
\hline & & & 1006 & 9491 & 1400 & 1408 & & 29.70 & 14.59 & collected data until runner \\
\hline & & & 1011 & 9194 & 1453 & 1457 & f1011_H_4 & 29.70 & 14.59 & \\
\hline & & & 1011 & 9194 & 1548 & 1555 & f1011_H_5 & 29.68 & 14.58 & \\
\hline & & & 1011 & 9194 & 1630 & 1635 & f1011_H_6 & 29.67 & 14.57 & \\
\hline \multirow[t]{5}{*}{$5 / 6 / 2012$} & Unit 1 & 4.9/5.0 MW -800 cfs & 1011 & 9194 & 826 & 834 & f1011_L_5 & 29.64 & 14.56 & \\
\hline & & Low FB: 616 ft & 1011 & 9194 & 936 & 941 & f1011_L_6 & 29.64 & 14.56 & \\
\hline & & & 1006 & 9194 & 1029 & 1033 & f1006_L_7 & 29.62 & 14.55 & \\
\hline & & & 1011 & 9194 & 1126 & 1130 & f1011_L_8 & 29.61 & 14.54 & \\
\hline & & & 1006 & 9194 & 1207 & 1217 & f1006_L_9 & 29.60 & 14.54 & \\
\hline
\end{tabular}




\begin{tabular}{|c|c|c|c|c|c|c|c|c|c|c|}
\hline Test Date & Location & Test Condition & $\begin{array}{c}\text { Fish } \\
\text { ID }\end{array}$ & $\begin{array}{c}\text { Tag } \\
\text { Number }\end{array}$ & $\begin{array}{c}\text { Deployment } \\
\text { Time }\end{array}$ & $\begin{array}{c}\text { Recovery } \\
\text { Time } \\
\end{array}$ & File Name & $\begin{array}{c}\text { Barometric } \\
\text { Pressure }\end{array}$ & & Notes \\
\hline & & & 1011 & 9194 & 1332 & 1338 & f1011_L_10 & 29.57 & 14.52 & \\
\hline \multirow[t]{4}{*}{ 5/6/2012 } & Unit 1 & $3.0 \mathrm{MW}-550 \mathrm{cfs}$ & 1006 & 9194 & 1431 & 1440 & f1006_XL_1 & 29.55 & 14.51 & \\
\hline & & Low FB: $\sim 616 \mathrm{ft}$ & 1110 & 9194 & 1527 & 1532 & f1110_XL_2 & 29.54 & 14.51 & \\
\hline & & & 1006 & 9194 & 1628 & 1634 & f1006_XL_3 & 29.52 & 14.50 & \\
\hline & & & 1011 & 9531 & 1654 & 1659 & f1011_XL_4 & 29.51 & 14.49 & \\
\hline \multirow[t]{19}{*}{ 5/8/2012 } & weir & Low forebay & 1006 & 9194 & 845 & 855 & f1006_w_1 & 29.37 & 14.43 & \\
\hline & Juvenile pipe & $\sim 616 \mathrm{ft}$ & 664 & 9340 & 925 & 933 & f664_w_2 & 29.37 & 14.43 & \\
\hline & & & 1106 & 9531 & 957 & 1056 & f1106_w_4 & 29.36 & 14.42 & \\
\hline & & & 1011 & 9271 & 1030 & 1038 & f1011_w_3 & 29.35 & 14.42 & \\
\hline & & & 1006 & 9194 & 1056 & 1106 & f1006_w_5 & 29.35 & 14.42 & \\
\hline & & & 664 & 9340 & 1126 & 1132 & f664_w_8 & 29.36 & 14.42 & \\
\hline & & & 1011 & 9271 & 1205 & 1213 & f1011_w_6 & 29.34 & 14.41 & \\
\hline & & & 1110 & 9554 & 1206 & 1212 & f1110_w_7 & 29.34 & 14.41 & \\
\hline & & & 1106 & 9531 & 1236 & 1241 & f1106_w_9 & 29.33 & 14.41 & \\
\hline & & & 1006 & 9194 & 1235 & 1241 & f1006_w_11 & 29.33 & 14.41 & \\
\hline & & & 1015 & 9271 & 1307 & 1312 & f1015_w_10 & 29.33 & 14.41 & bad acceleration \\
\hline & & & 1110 & 9554 & 1338 & 1345 & f1110_w_12 & 29.33 & 14.41 & \\
\hline & & & 664 & 9340 & 1339 & 1346 & f664_w_13 & 29.33 & 14.41 & \\
\hline & & & 1106 & 9531 & 1403 & 1410 & f1106_w_14 & 29.32 & 14.40 & \\
\hline & & & 1015 & 9271 & 1440 & 1452 & & 29.31 & 14.40 & no data \\
\hline & & & 1110 & 9554 & 1440 & 1452 & f1110_w_15 & 29.31 & 14.40 & \\
\hline & & & 1006 & 9194 & 1505 & 1512 & & 29.29 & 14.39 & battery??? \\
\hline & & & 664 & 9340 & 1600 & 1605 & f664_w_16 & 29.28 & 14.38 & \\
\hline & & & 1011 & 9531 & 1533 & 1540 & f1011_w_17 & 29.29 & 14.39 & pressure? \\
\hline \multirow[t]{2}{*}{ 5/9/2012 } & weir & Low forebay & 1006 & 9194 & 1049 & 1104 & f1006_adult_1 & 29.50 & 14.49 & \\
\hline & Adult pipe & $\sim 616 \mathrm{ft}$ & 1106 & 9531 & 1147 & 1157 & f1106_adult_2 & 29.50 & 14.49 & \\
\hline \multicolumn{11}{|c|}{ High Forebay - 634 ft MSL } \\
\hline \multirow[t]{4}{*}{$5 / 18 / 2012$} & Unit 1 & & 115 & 9531 & 1407 & 1409 & f115_h_6-5_1 & 29.35 & 14.42 & \\
\hline & & $6.5 \mathrm{MW}$ & 202 & 8990 & 1408 & 1412 & f202_h_6_3 & 29.35 & 14.42 & \\
\hline & & High forebay: $\sim 634 \mathrm{ft}$ & 244 & 8570 & 1408 & 1411 & f244_h_6_2 & 29.35 & 14.42 & \\
\hline & & & 251 & 8161 & 1409 & 751 & f251_6_4 & 29.35 & 14.42 & next day - was in pipe \\
\hline \multirow[t]{6}{*}{$5 / 19 / 2012$} & Unit 1 & 4.9/5.0 MW & 699 & 9271 & 749 & 754 & f699_h_4_2 & 29.32 & 14.40 & \\
\hline & & High forebay: $\sim 634 \mathrm{ft}$ & 115 & 9930 & 749 & 753 & f115_h_4_1 & 29.32 & 14.40 & \\
\hline & & & 223 & 9920 & 750 & 754 & f223_4_3 & 29.32 & 14.40 & orange balloon detached \\
\hline & & & 250 & 9536 & 751 & 754 & f250_4_4 & 29.32 & 14.40 & \\
\hline & & & 272 & 9948 & 752 & 757 & f272_4_5 & 29.32 & 14.40 & \\
\hline & & & 221 & 9960 & 752 & 755 & f221_4_6 & 29.32 & 14.40 & \\
\hline
\end{tabular}




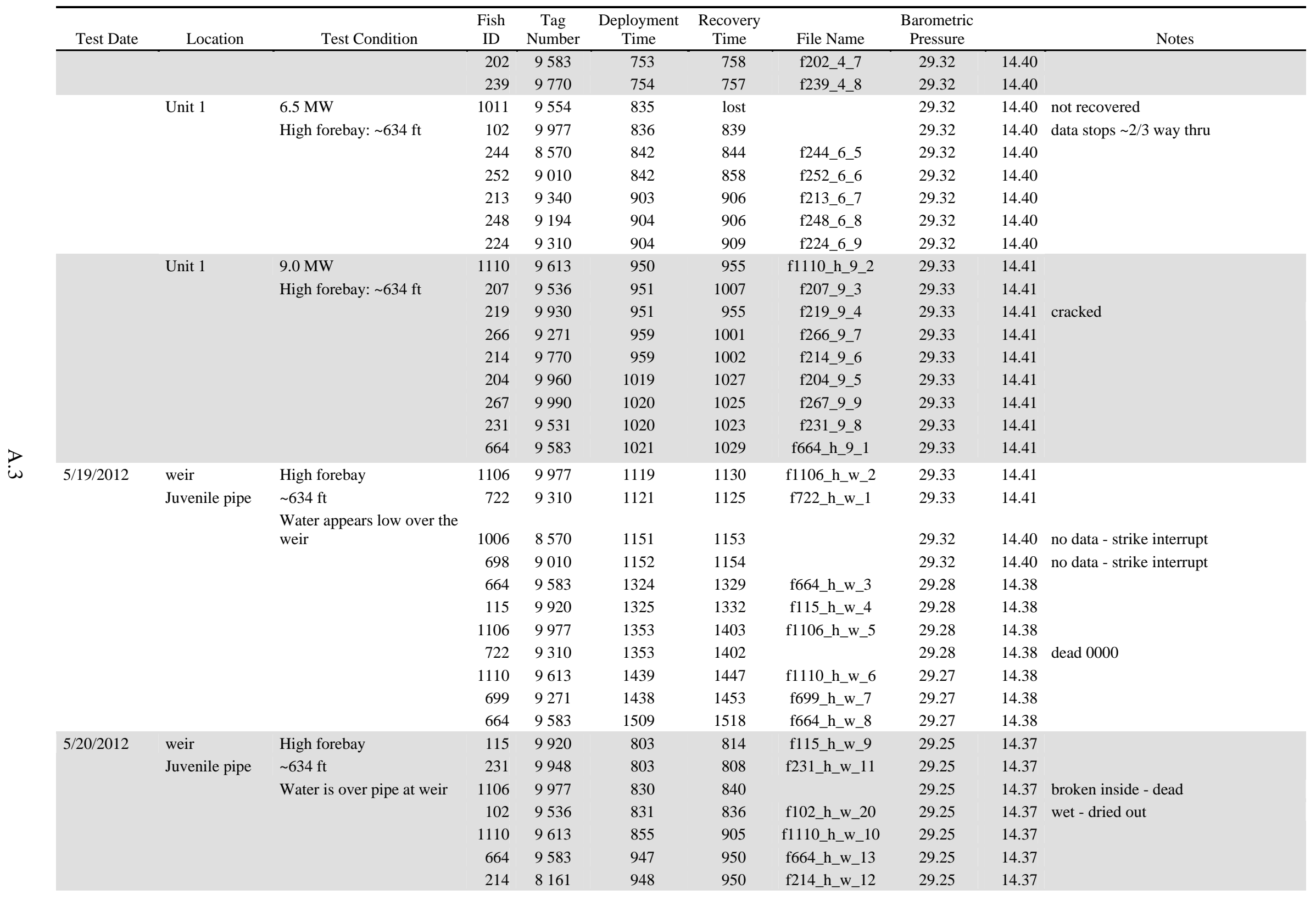




\begin{tabular}{|c|c|c|c|c|c|c|c|c|c|c|}
\hline Test Date & Location & Test Condition & $\begin{array}{l}\text { Fish } \\
\text { ID }\end{array}$ & $\begin{array}{c}\text { Tag } \\
\text { Number }\end{array}$ & $\begin{array}{c}\text { Deployment } \\
\text { Time }\end{array}$ & $\begin{array}{c}\text { Recovery } \\
\text { Time }\end{array}$ & File Name & $\begin{array}{c}\text { Barometric } \\
\text { Pressure }\end{array}$ & & Notes \\
\hline & & & 698 & 9010 & 1025 & 1028 & & 29.25 & 14.37 & no data - interrupt \\
\hline & & & 699 & 9271 & 1026 & 1032 & f699_h_w_14 & 29.25 & 14.37 & \\
\hline & & & 115 & 9920 & 1057 & 1102 & f115_h_w_15 & 29.25 & 14.37 & \\
\hline & & & 1110 & 9613 & 1056 & 1101 & f1110_h_w_16 & 29.25 & 14.37 & \\
\hline & & & 231 & 9948 & 1218 & 1221 & f231_h_w_17 & 29.25 & 14.37 & \\
\hline & & & 664 & 9583 & 1219 & 1223 & f664_h_w_18 & 29.25 & 14.37 & \\
\hline & & & 699 & 9271 & 1251 & 1256 & f699_h_w_19 & 29.25 & 14.37 & \\
\hline & & & 115 & 9920 & 1250 & 1256 & & 29.25 & 14.37 & tag ripped off - dead \\
\hline \multirow[t]{4}{*}{$5 / 21 / 2012$} & weir & High forebay & 1110 & 9613 & 825 & 826 & $\begin{array}{c}\text { f1110_h_W_ad } \\
\text { ult1 }\end{array}$ & 29.18 & 14.33 & \\
\hline & Adult pipe & $\begin{array}{l}\sim 634 \mathrm{ft} \\
\text { Water is over pipe at weir }\end{array}$ & 699 & 9271 & 824 & 829 & $\underset{\text { ult2 }}{\text { f699_H_W_ad }}$ & 29.18 & 14.33 & \\
\hline & weir & $\sim 634.6 \mathrm{ft}$ & 214 & & 1012 & 1014 & f214 & 29.15 & 14.32 & On adult - tag ripped off \\
\hline & Adult pipe & & 250 & & 1022 & 1031 & $\mathrm{f} 250$ & 29.15 & 14.32 & On adult - tag stayed on \\
\hline
\end{tabular}




\section{Appendix B}

\section{Data Summary Tables for Each Sensor Fish Release}




\section{Sensor Fish Weir Passage - Low-Forebay Elevation (616 ft MSL) Significant Events}




\begin{tabular}{|c|c|c|c|c|c|c|}
\hline File Name & $\begin{array}{c}\text { Number of } \\
\text { Events }\end{array}$ & $\begin{array}{c}\text { Average } \\
\text { Magnitude per } \\
\text { Run } \\
\end{array}$ & $\begin{array}{c}\text { Event } \\
\text { Magnitude } \\
(g)\end{array}$ & $\begin{array}{c}\text { Time of } \\
\text { Event }\end{array}$ & Location & Event Type \\
\hline \multicolumn{7}{|c|}{ FB 616 MSL - Juvenile Pipe: } \\
\hline \multirow[t]{12}{*}{ f1006_w_1 } & 12 & 151.5 & 256.2 & 1.084 & Impact & Collision \\
\hline & & & 249.9 & 2.003 & Spillway & Collision \\
\hline & & & 153.9 & 5.6035 & Spillway & Collision \\
\hline & & & 148.4 & 4.6685 & Spillway & Collision \\
\hline & & & 143.3 & 3.569 & Spillway & Collision \\
\hline & & & 140.7 & 6.0645 & Plunge & Collision \\
\hline & & & 138.4 & 4.2135 & Spillway & Collision \\
\hline & & & 130.5 & 4.9535 & Spillway & Collision \\
\hline & & & 125.4 & 2.2035 & Spillway & Collision \\
\hline & & & 124.7 & 3.1315 & Spillway & Collision \\
\hline & & & 104.8 & 3.8405 & Spillway & Collision \\
\hline & & & 102 & 2.813 & Spillway & Collision \\
\hline \multirow[t]{2}{*}{ f664_w_2 } & 2 & 109.3 & 113.4 & 1.19 & Impact & Collision \\
\hline & & & 105.2 & 5.5595 & Spillway & Collision \\
\hline \multirow[t]{5}{*}{ f1011_w_3 } & 5 & 113.8 & 133.8 & 1.101 & Impact & Collision \\
\hline & & & 112.4 & 3.9925 & Spillway & Collision \\
\hline & & & 111.4 & 1.793 & Spillway & Collision \\
\hline & & & 110 & 2.0825 & Spillway & Collision \\
\hline & & & 101.5 & 4.676 & Spillway & Collision \\
\hline \multirow[t]{5}{*}{ f1106_w_4 } & 5 & 126.0 & 142.8 & 4.137 & Spillway & Collision \\
\hline & & & 141.7 & 1.7945 & Spillway & Collision \\
\hline & & & 128.5 & 4.4505 & Spillway & Collision \\
\hline & & & 114.1 & 3.536 & Spillway & Collision \\
\hline & & & 103 & 5.867 & Spillway & Collision \\
\hline \multirow[t]{6}{*}{ f1006_w_5 } & 6 & 127.8 & 140 & 3.254 & Spillway & Collision \\
\hline & & & 133.4 & 2.7265 & Spillway & Collision \\
\hline & & & 128.2 & 1.1325 & Impact & Collision \\
\hline & & & 127.8 & 3.074 & Spillway & Collision \\
\hline & & & 127 & 3.5205 & Spillway & Collision \\
\hline & & & 110.6 & 5.365 & Spillway & Collision \\
\hline \multirow[t]{6}{*}{ f1011_w_6 } & 6 & 126.6 & 154.6 & 4.69 & Spillway & Collision \\
\hline & & & 150.9 & 1.068 & Impact & Collision \\
\hline & & & 134.6 & 12.475 & Tailrace & Collision \\
\hline & & & 127.6 & 1.8265 & Spillway & Collision \\
\hline & & & 101.3 & 3.238 & Spillway & Collision \\
\hline & & & 98.4 & 4.036 & Spillway & Collision \\
\hline \multirow[t]{7}{*}{ f1110_w_7 } & 10 & 124.0 & 187 & 3.398 & Spillway & Collision \\
\hline & & & 132.8 & 1.092 & Impact & Shear \\
\hline & & & 129.2 & 4.105 & Spillway & Collision \\
\hline & & & 127.1 & 1.481 & Spillway & Collision \\
\hline & & & 119.1 & 6.2035 & Plunge & Collision \\
\hline & & & 118 & 4.321 & Spillway & Collision \\
\hline & & & 117.5 & 5.8495 & Spillway & Collision \\
\hline
\end{tabular}




\begin{tabular}{|c|c|c|c|c|c|c|}
\hline File Name & $\begin{array}{l}\text { Number of } \\
\text { Events }\end{array}$ & $\begin{array}{c}\text { Average } \\
\text { Magnitude per } \\
\text { Run }\end{array}$ & $\begin{array}{c}\text { Event } \\
\text { Magnitude } \\
(g)\end{array}$ & $\begin{array}{c}\text { Time of } \\
\text { Event }\end{array}$ & Location & Event Type \\
\hline & & & 108.9 & 9.947 & Tailrace & Collision \\
\hline & & & 101.2 & 5.4825 & Spillway & Collision \\
\hline & & & 99.1 & 2.2165 & Spillway & Collision \\
\hline \multirow[t]{4}{*}{ f664_w_8 } & 4 & 124.3 & 173.6 & 1.0505 & Impact & Collision \\
\hline & & & 113.8 & 5.2555 & Spillway & Collision \\
\hline & & & 106.6 & 5.7015 & Spillway & Collision \\
\hline & & & 103.2 & 5.0705 & Spillway & Collision \\
\hline \multirow[t]{7}{*}{ f1106_w_9 } & 7 & 119.0 & 147.5 & 1.9875 & Spillway & Collision \\
\hline & & & 135.4 & 1.5635 & Spillway & Collision \\
\hline & & & 132.2 & 3.9505 & Spillway & Collision \\
\hline & & & 124.6 & 2.3465 & Spillway & Collision \\
\hline & & & 98.5 & 1.424 & Spillway & Collision \\
\hline & & & 97.5 & 2.8475 & Spillway & Collision \\
\hline & & & 97.3 & 4.5625 & Spillway & Collision \\
\hline \multirow[t]{10}{*}{ f1006_w_11 } & 10 & 134.2 & 167.4 & 2.2045 & Spillway & Collision \\
\hline & & & 166.6 & 5.4755 & Spillway & Collision \\
\hline & & & 162.5 & 2.77 & Spillway & Collision \\
\hline & & & 159 & 2.014 & Spillway & Collision \\
\hline & & & 137.6 & 5.7775 & Spillway & Collision \\
\hline & & & 132.1 & 2.715 & Spillway & Collision \\
\hline & & & 109.3 & 1.3175 & Impact & Collision \\
\hline & & & 105.8 & 1.3635 & Spillway & Collision \\
\hline & & & 102 & 3.1275 & Spillway & Collision \\
\hline & & & 100.1 & 4.1265 & Spillway & Collision \\
\hline \multirow[t]{6}{*}{ f1110_w_12 } & 6 & 123.4 & 160.1 & 1.052 & Impact & Collision \\
\hline & & & 130.7 & 2.4055 & Spillway & Collision \\
\hline & & & 125.5 & 2.17 & Spillway & Collision \\
\hline & & & 116.6 & 3.3345 & Spillway & Collision \\
\hline & & & 110.1 & 5.978 & Plunge & Collision \\
\hline & & & 97.5 & 1.465 & Spillway & Collision \\
\hline \multirow[t]{3}{*}{ f664_w_13 } & 3 & 125.9 & 143.9 & 1.032 & Impact & Collision \\
\hline & & & 123.5 & 5.3425 & Spillway & Collision \\
\hline & & & 110.4 & 2.277 & Spillway & Collision \\
\hline f1106_w_14 & 1 & 132.1 & 132.1 & 2.4395 & Spillway & Collision \\
\hline \multirow[t]{5}{*}{ f1110_w_15 } & 5 & 128.2 & 163.4 & 1.0445 & Impact & Collision \\
\hline & & & 126.7 & 2.3845 & Spillway & Collision \\
\hline & & & 126.2 & 2.6435 & Spillway & Collision \\
\hline & & & 119.2 & 5.8035 & Plunge & Collision \\
\hline & & & 105.6 & 2.092 & Spillway & Collision \\
\hline \multirow[t]{3}{*}{ f664_w_16 } & 3 & 120.1 & 161.8 & 0.996 & Impact & Collision \\
\hline & & & 101.9 & 1.4045 & Spillway & Collision \\
\hline & & & 96.7 & 5.505 & Spillway & Collision \\
\hline
\end{tabular}




\begin{tabular}{|c|c|c|c|c|c|c|c|}
\hline File Name & $\begin{array}{c}\text { Number o } \\
\text { Events }\end{array}$ & & $\begin{array}{c}\text { Average } \\
\text { Magnitude per } \\
\text { Run }\end{array}$ & $\begin{array}{c}\text { Event } \\
\text { Magnitude } \\
(g)\end{array}$ & $\begin{array}{c}\text { Time of } \\
\text { Event }\end{array}$ & Location & Event Type \\
\hline \multirow[t]{3}{*}{ f1011_w_17 } & 3 & & 125.8 & 144.7 & 1.986 & Spillway & Collision \\
\hline & & & & 122.4 & 1.1465 & Impact & Collision \\
\hline & & & & 110.3 & 4.712 & Spillway & Collision \\
\hline \multirow[t]{4}{*}{ Mean } & 5.5 & & 125.8 & & & & \\
\hline & & & Severe & 157.6 & All & 128.5 & \\
\hline & & & STDEV & 31.79 & STDEV & 28.19 & \\
\hline & & & SE & 7.95 & $\mathrm{SE}$ & 3.01 & \\
\hline \multicolumn{8}{|c|}{ FB 616 MSL - Adult Pipe: } \\
\hline \multirow[t]{4}{*}{ f1006_adult_1* } & & 4 & 186.1 & 230.4 & 1.8945 & Spillway & Collision \\
\hline & & & & 200.4 & 3.8105 & Spillway & Collision \\
\hline & & & & 160.6 & 4.975 & Spillway & Collision \\
\hline & & & & 152.8 & 3.553 & Spillway & Collision \\
\hline \multirow[t]{5}{*}{ f1106_adult_2* } & & 1 & 125.5 & 125.5 & 1.4385 & Impact & Collision \\
\hline & Mean & 2.5 & 155.8 & & & & \\
\hline & & & Severe & 177.95 & All & 173.94 & \\
\hline & & & STDEV & 74.18 & STDEV & 41.41 & \\
\hline & & & SE & 52.45 & SE & 18.52 & \\
\hline
\end{tabular}




\section{Sensor Fish Weir Passage -} High-Forebay Elevation (634 ft MSL) Significant Events 


\begin{tabular}{|c|c|c|c|c|c|c|}
\hline File Name & $\begin{array}{c}\text { Number } \\
\text { of Events }\end{array}$ & $\begin{array}{c}\text { Average } \\
\text { Magnitude per } \\
\text { Run } \\
\end{array}$ & $\begin{array}{c}\text { Event Magnitude } \\
(\mathrm{g})\end{array}$ & $\begin{array}{c}\text { Time of } \\
\text { Event }\end{array}$ & Location & $\begin{array}{l}\text { Event } \\
\text { Type }\end{array}$ \\
\hline \multicolumn{7}{|c|}{ FB 634 MSL - Juvenile Pipe: } \\
\hline \multirow[t]{6}{*}{ f722_h_w_1 } & 6 & 123.2 & 144 & 2.371 & Spillway & Collision \\
\hline & & & 129.8 & 1.521 & Impact & Shear \\
\hline & & & 127 & 2.657 & Spillway & Collision \\
\hline & & & 118.8 & 4.302 & Spillway & Collision \\
\hline & & & 110.2 & 4.083 & Spillway & Collision \\
\hline & & & 109.1 & 2.954 & Spillway & Collision \\
\hline \multirow[t]{2}{*}{ f1106_h_w_2 } & 2 & 130.3 & 133.4 & 6.618 & Plunge & Collision \\
\hline & & & 127.1 & 1.4545 & Impact & Collision \\
\hline \multirow[t]{3}{*}{ f664_h_w_3 } & 3 & 131.4 & 134.3 & 4.9575 & Spillway & Collision \\
\hline & & & 130.2 & 1.4575 & Impact & Collision \\
\hline & & & 129.8 & 6.062 & Spillway & Collision \\
\hline \multirow{6}{*}{ f115_h_w_4 } & 6 & 156.2 & 188.1 & 1.4375 & Impact & Collision \\
\hline & & & 184.6 & 3.853 & Spillway & Collision \\
\hline & & & 176.9 & 4.786 & Spillway & Collision \\
\hline & & & 171.9 & 5.386 & Spillway & Collision \\
\hline & & & 109.7 & 5.2235 & Spillway & Collision \\
\hline & & & 105.7 & 4.9895 & Spillway & Collision \\
\hline \multirow[t]{2}{*}{ f1106_h_w_5 } & 2 & 106.7 & 109.6 & 1.4485 & Impact & Collision \\
\hline & & & 103.7 & 4.191 & Spillway & Collision \\
\hline \multirow[t]{6}{*}{ f1110_h_w_6 } & 6 & 146.0 & 186.2 & 4.2485 & Spillway & Collision \\
\hline & & & 160.1 & 1.7045 & Impact & Collision \\
\hline & & & 156.1 & 6.0475 & Plunge & Collision \\
\hline & & & 138.2 & 5.262 & Spillway & Collision \\
\hline & & & 126.6 & 2.524 & Spillway & Collision \\
\hline & & & 108.9 & 5.019 & Spillway & Collision \\
\hline f699_h_w_7 & 1 & 149.5 & 149.5 & 1.5555 & Impact & Shear \\
\hline \multirow[t]{5}{*}{ f664_h_w_8 } & 5 & 113.1 & 152.1 & 1.494 & Impact & Collision \\
\hline & & & 112.9 & 1.9575 & Spillway & Collision \\
\hline & & & 104.9 & 2.9245 & Spillway & Collision \\
\hline & & & 97.9 & 4.6505 & Spillway & Collision \\
\hline & & & 97.6 & 3.5585 & Spillway & Collision \\
\hline \multirow[t]{5}{*}{ f115_h_w_9 } & 5 & 156.3 & 202.2 & 3.609 & Spillway & Collision \\
\hline & & & 197.3 & 5.7965 & Spillway & Collision \\
\hline & & & 169.7 & 1.577 & Impact & Shear \\
\hline & & & 110.6 & 3.9875 & Spillway & Collision \\
\hline & & & 101.7 & 5.6055 & Spillway & Collision \\
\hline \multirow[t]{3}{*}{ f1110_h_w_10 } & 3 & 131.0 & 159.9 & 1.5405 & Impact & Shear \\
\hline & & & 123.8 & 5.008 & Spillway & Collision \\
\hline & & & 109.4 & 6.046 & Spillway & Collision \\
\hline f231_h_w_11 & 1 & 122.6 & 122.623 & 1.515 & Impact & Collision \\
\hline \multirow[t]{2}{*}{ f214_h_w_12 } & 2 & 139.8 & 157.681 & 1.68 & Impact & Collision \\
\hline & & & 121.834 & 3.155 & Spillway & Collision \\
\hline
\end{tabular}




\begin{tabular}{|c|c|c|c|c|c|c|}
\hline File Name & $\begin{array}{c}\text { Number } \\
\text { of Events }\end{array}$ & $\begin{array}{c}\text { Average } \\
\text { Magnitude per } \\
\text { Run } \\
\end{array}$ & $\begin{array}{c}\text { Event Magnitude } \\
(\mathrm{g})\end{array}$ & $\begin{array}{c}\text { Time of } \\
\text { Event }\end{array}$ & Location & $\begin{array}{l}\text { Event } \\
\text { Type }\end{array}$ \\
\hline f664_h_w_13 & 1 & 156.4 & 156.4 & 1.484 & Impact & Collision \\
\hline \multirow[t]{2}{*}{ f699_h_w_14 } & 3 & 103.5 & 108.4 & 4.6885 & Spillway & Collision \\
\hline & & & $\begin{array}{c}103 \\
99.1\end{array}$ & $\begin{array}{l}1.948 \\
1.48\end{array}$ & $\begin{array}{l}\text { Spillway } \\
\text { Impact }\end{array}$ & $\begin{array}{l}\text { Collision } \\
\text { Collision }\end{array}$ \\
\hline \multirow[t]{8}{*}{ f115_h_w_15 } & 8 & 132.0 & 177.7 & 3.035 & Spillway & Collision \\
\hline & & & 146.2 & 1.609 & Impact & Shear \\
\hline & & & 140.7 & 4.9465 & Spillway & Collision \\
\hline & & & 140.5 & 2.79 & Spillway & Collision \\
\hline & & & 120.1 & 4.6515 & Spillway & Collision \\
\hline & & & 119.2 & 4.0975 & Spillway & Collision \\
\hline & & & 107.1 & 2.2065 & Spillway & Collision \\
\hline & & & 104.3 & 4.4825 & Spillway & Collision \\
\hline \multirow[t]{3}{*}{ f1110_h_w_16 } & 3 & 125.1 & 130.3 & 2.494 & Spillway & Collision \\
\hline & & & 129.9 & 5.1185 & Spillway & Collision \\
\hline & & & 115 & 1.445 & Impact & Shear \\
\hline f231_h_w_17 & 1 & 142.6 & 142.596 & 1.14 & Impact & Collision \\
\hline \multirow[t]{6}{*}{ f664_h_w_18 } & 6 & 128.2 & 147.8 & 1.5275 & Spillway & Collision \\
\hline & & & 138.9 & 3.749 & Spillway & Collision \\
\hline & & & 136.5 & 1.5085 & Impact & Shear \\
\hline & & & 121.3 & 5.0955 & Spillway & Collision \\
\hline & & & 113.5 & 5.438 & Spillway & Collision \\
\hline & & & 111.1 & 3.498 & Spillway & Collision \\
\hline f699_h_w_19 & 1 & 130.9 & 130.9 & 2.3405 & Spillway & Collision \\
\hline \multirow[t]{2}{*}{ f102_h_w_20 } & 2 & 107.3 & 107.9 & 1.5765 & Spillway & Collision \\
\hline & & & 106.6 & 1.557 & Impact & Shear \\
\hline \multirow[t]{4}{*}{ Mean } & 3.35 & 131.6 & & & & \\
\hline & & Severe & 147.08 & All & 132.34 & \\
\hline & & STDEV & 26.70 & STDEV & 26.6 & \\
\hline & & SE & 5.97 & SE & 3.25 & \\
\hline
\end{tabular}




\begin{tabular}{|c|c|c|c|c|c|c|}
\hline File Name & $\begin{array}{c}\text { Number } \\
\text { of Events }\end{array}$ & $\begin{array}{c}\text { Average } \\
\text { Magnitude } \\
\text { per Run }\end{array}$ & $\begin{array}{c}\text { Event } \\
\text { Magnitude }(g) \\
\end{array}$ & $\begin{array}{c}\text { Time of } \\
\text { Event }\end{array}$ & Location & $\begin{array}{l}\text { Event } \\
\text { Type }\end{array}$ \\
\hline \multicolumn{7}{|c|}{ FB 634 MSL - Adult Pipe: } \\
\hline \multirow[t]{5}{*}{ f1110_h_W_adult1* } & 5 & 125.6 & 146.9 & 1.2485 & Impact & Shear \\
\hline & & & 130.1 & 2.8095 & Spillway & Collision \\
\hline & & & 128.2 & 3.9655 & Spillway & Collision \\
\hline & & & 125.3 & 5.1215 & Spillway & Collision \\
\hline & & & 97.5 & 5.4135 & Spillway & Collision \\
\hline \multirow[t]{2}{*}{ f699_H_W_adult2* } & 2 & 117.5 & 126 & 1.4565 & Impact & Shear \\
\hline & & & 108.9 & 3.7445 & Spillway & Collision \\
\hline \multirow[t]{4}{*}{ Mean } & 3.5 & 121.5 & & & & \\
\hline & & Severe & 136.45 & All & 123.27 & \\
\hline & & STDEV & 14.8 & STDEV & 15.87 & \\
\hline & & SE & 10.45 & SE & 6.00 & \\
\hline \multicolumn{7}{|l|}{ Attached to adult: } \\
\hline $\mathrm{f} 214$ & 6 & 119.5 & 151.527 & 0.95 & Spillway & Collision \\
\hline \multirow{5}{*}{\multicolumn{3}{|c|}{ fish had a bruise at recapture; fine at $48 \mathrm{~h}$}} & 126.928 & 0.82 & Impact & Collision \\
\hline & & & 125.197 & 0.885 & Spillway & Collision \\
\hline & & & 112.192 & 2.04 & Spillway & Collision \\
\hline & & & 105.19 & 4.21 & Spillway & Collision \\
\hline & & & 95.708 & 3.235 & Spillway & Collision \\
\hline $\mathrm{f} 250$ & 4 & 130.1 & 152.157 & 1.065 & Spillway & Collision \\
\hline \multirow{3}{*}{\multicolumn{3}{|c|}{ scrapes on head near eye; fish fine at $48 \mathrm{~h}$}} & 130.365 & 1.025 & Impact & Shear \\
\hline & & & 128.684 & 1.145 & Spillway & Collision \\
\hline & & & 109.204 & 1.045 & Spillway & Collision \\
\hline \multirow[t]{4}{*}{ Mean } & 5 & 124.8 & & & & \\
\hline & & Severe & 151.842 & All & 123.72 & \\
\hline & & STDEV & 0.45 & STDEV & 18.66 & \\
\hline & & SE & 0.315 & SE & 5.90 & \\
\hline
\end{tabular}




\section{Sensor Fish Turbine Passage - \\ Low-Forebay Elevation (616 ft MSL) \\ Significant Events}




\begin{tabular}{|c|c|c|c|c|c|c|}
\hline Test Condition & File Name & $\begin{array}{l}\text { Number of } \\
\text { Events }\end{array}$ & $\begin{array}{c}\text { Event } \\
\text { Magnitude }(g)\end{array}$ & $\begin{array}{c}\text { Time of } \\
\text { Event }\end{array}$ & Location & Event Type \\
\hline $2.8 \mathrm{MW}-540 \mathrm{cfs}$ & f114_L_2 & 0 & & & & \\
\hline Low Forebay & f635_L_3 & 1 & 144.5 & -0.046 & Runner & Collision \\
\hline $3.0 \mathrm{MW}-550 \mathrm{cfs}$ & f1006_XL_1 & 1 & 145 & -0.604 & Wicket Gate & Collision \\
\hline \multirow[t]{6}{*}{ Low Forebay } & f1110_XL_2 & 1 & 145 & -0.4945 & Wicket Gate & Collision \\
\hline & f1006_XL_3 & 0 & & & & \\
\hline & f1011_XL_4 & 0 & & & & \\
\hline & Avg Events/run & 0.50 & 144.83 & Mean & & \\
\hline & With events & 0.50 & 0.289 & STDEV & & \\
\hline & & & 0.167 & SE & & \\
\hline $4.9 \mathrm{MW}-800 \mathrm{cfs}$ & F115_L_1 & 0 & & & & \\
\hline \multirow[t]{14}{*}{ Low Forebay } & f1110_L_2 & 2 & 113.1 & -0.0565 & Runner & Collision \\
\hline & & & 100 & -0.0835 & Wicket Gate & Collision \\
\hline & F664_L_3 & 1 & 135.7 & -0.3695 & Wicket Gate & Collision \\
\hline & f1011_L_5 & 0 & & & & \\
\hline & f1011_L_6 & 0 & & & & \\
\hline & f1006_L_7 & 1 & 117.7 & -0.459 & Wicket Gate & Collision \\
\hline & f1011_L_8 & 0 & & & & \\
\hline & f1006_L_9 & 4 & 244.6 & -0.303 & Wicket Gate & Collision \\
\hline & & & 171.5 & -0.05 & Runner & Collision \\
\hline & & & 118.7 & -0.021 & Runner & Collision \\
\hline & & & 95.9 & -0.0795 & Runner & Shear \\
\hline & f1011_L_10 & $\mathbf{0}$ & 152.78 & Severe & 138.9 & All \\
\hline & Avg Events/run & 0.89 & 61.99 & Stdev & 49.4 & \\
\hline & With events & 0.44 & 30.99 & SE & 17.5 & \\
\hline $6.0 \mathrm{MW}-980 \mathrm{cfs}$ & f1011_m_1 & 0 & & & & \\
\hline \multirow[t]{8}{*}{ Low Forebay } & f900_m_2 & 1 & 147.6 & -0.612 & Wicket Gate & Collision \\
\hline & f1015_m_3 & 1 & 104.8 & -0.33 & Wicket Gate & Collision \\
\hline & f901_m_4 & 0 & & & & \\
\hline & f900_m_5 & 1 & 105 & -0.034 & Runner & Collision \\
\hline & f1015_m_6 & 1 & 171.5 & -0.185 & Wicket Gate & Collision \\
\hline & Avg Events/run & 0.67 & 132.23 & Mean & & \\
\hline & With events & 0.67 & 33.03 & STDEV & & \\
\hline & & & 16.51 & SE & & \\
\hline $7.0 \mathrm{MW}-1150 \mathrm{cfs}$ & f1011_H_1 & 2 & 120.2 & -0.001 & Runner & Collision \\
\hline \multirow[t]{8}{*}{ Low Forebay } & & & 108.4 & -0.0475 & Runner & Collision \\
\hline & f1011_H_3 & 0 & & & & \\
\hline & f1011_H_4 & 0 & & & & \\
\hline & f1011_H_5 & 0 & & & & \\
\hline & f1011_H_6 & 1 & 144.9 & -0.169 & Wicket Gate & Collision \\
\hline & Avg Events/run & 0.60 & 132.55 & Severe & 124.50 & All \\
\hline & With events & 0.40 & 17.47 & STDEV & 18.63 & \\
\hline & & & 12.35 & SE & 10.75 & \\
\hline
\end{tabular}


Sensor Fish Turbine Passage High-Forebay Elevation (634 ft MSL) Significant Events 


\begin{tabular}{|c|c|c|c|c|c|c|}
\hline Test Condition & File Name & $\begin{array}{l}\text { Number } \\
\text { of Events }\end{array}$ & $\begin{array}{c}\text { Event } \\
\text { Magnitude } \\
(g)\end{array}$ & $\begin{array}{c}\text { Time of } \\
\text { Event (s) }\end{array}$ & Location & $\begin{array}{l}\text { Event } \\
\text { Type }\end{array}$ \\
\hline 4.9 MW & f115_h_4_1 & 1 & 106.7 & -0.4 & Wicket Gate & Collision \\
\hline High Forebay & f699_h_4_2 & 1 & 112 & 12.052 & Draft Tube & Collision \\
\hline \multirow[t]{13}{*}{$650 \mathrm{cfs}$} & f223_4_3 & 1 & 177.113 & -0.095 & Runner & Collision \\
\hline & f250_4_4 & 1 & 108.607 & -0.125 & Runner & Shear \\
\hline & f272_4_5 & 2 & 144.741 & -0.14 & Runner & Collision \\
\hline & & & 113.884 & -0.17 & Wicket Gate & Collision \\
\hline & $\mathrm{f} 221 \_4 \_6$ & 2 & 144.727 & -0.11 & Runner & Shear \\
\hline & & & 136.426 & -0.425 & Runner & Shear \\
\hline & f202_4_7 & 1 & 101.756 & 0.015 & Runner & Collision \\
\hline & f239_4_8 & 3 & 135.329 & 0 & Runner & Collision \\
\hline & & & 122.072 & -0.14 & Runner & Collision \\
\hline & & & 104.086 & -0.565 & Wicket Gate & Collision \\
\hline & Avg Events/run & 1.5 & 128.9 & Severe & 125.6 & All \\
\hline & With events & 1 & 26.17 & Stdev & 22.58 & \\
\hline & & & 9.25 & SE & 6.52 & \\
\hline 6.5 MW & f115_h_6-5_1 & 0 & & & & \\
\hline High Forebay & f244_h_6_2 & 0 & & & & \\
\hline \multirow[t]{11}{*}{820 cfs } & f202_h_6_3 & 2 & 106.523 & -0.015 & runner & Collision \\
\hline & & & 96.862 & -0.12 & runner & Shear \\
\hline & f244_6_5 & 0 & & & & \\
\hline & f252_6_6 & 1 & 167.084 & -0.035 & runner & Collision \\
\hline & f213_6_7 & 0 & & & & \\
\hline & f248_6_8 & 0 & & & & \\
\hline & f224_6_9 & 2 & 154.895 & -0.04 & runner & Collision \\
\hline & & & 107.457 & -0.01 & runner & Collision \\
\hline & Avg Events/run & 0.625 & 142.8 & Severe & 126.6 & All \\
\hline & With events & 0.375 & 32.03 & Stdev & 31.99 & \\
\hline & & & 18.49 & SE & 14.31 & \\
\hline 9.0 MW & f664_h_9_1 & 1 & 185.4 & -0.037 & runner & Shear \\
\hline High Forebay & f1110_h_9_2 & 1 & 115.4 & -0.303 & wicket gate & Collision \\
\hline \multirow[t]{13}{*}{1150 cfs } & f207_9_3 & 3 & 172.1 & -0.025 & runner & Collision \\
\hline & & & 165.575 & -0.47 & wicket gate & Collision \\
\hline & & & 137.505 & 0.035 & runner & Collision \\
\hline & f266_9_7 & 1 & 132.046 & -0.03 & runner & Shear \\
\hline & f214_9_6 & 2 & 118.694 & 0.015 & runner & Collision \\
\hline & & & 113.19 & -0.04 & runner & Collision \\
\hline & f204_9_5 & 0 & & & & \\
\hline & f267_9_9 & 1 & 112.383 & -0.135 & runner & Shear \\
\hline & f231_9_8 & 2 & 144.867 & -0.035 & runner & Collision \\
\hline & & & 110.301 & 0.025 & runner & Collision \\
\hline & Avg Events/run & 1.375 & 140.1 & Severe & 137.0 & All \\
\hline & With events & 0.875 & 28.87 & Stdev & 26.77 & \\
\hline & & & 10.91 & SE & 8.07 & \\
\hline
\end{tabular}




\section{Sensor Fish Turbine Passage - Pressure Nadir Under the Runner}




\begin{tabular}{|c|c|c|c|c|c|}
\hline Test Condition & File Name & $\begin{array}{l}\text { Forebay } \\
\text { Elevation } \\
\text { (ft MSL) }\end{array}$ & $\begin{array}{l}\text { Tailwater } \\
\text { Elevation } \\
\text { (ft MSL) }\end{array}$ & $\begin{array}{c}\text { Turbine } \\
\text { MW }\end{array}$ & Nadir (psia) \\
\hline \multicolumn{6}{|c|}{ Low Forebay - 616 ft MSL } \\
\hline $2.8 \mathrm{MW}-540 \mathrm{cfs}$ & f114_L_2 & $\sim 616.5$ & & 2.8 & 21.06 \\
\hline Low Forebay & f635_L_3 & $\sim 616.5$ & & 2.8 & 20.87 \\
\hline $3.0 \mathrm{MW}-550 \mathrm{cfs}$ & f1006_XL_1 & 615.95 & 529.41 & 3.0 & 19.5085 \\
\hline \multirow[t]{4}{*}{ Low Forebay } & f1110_XL_2 & 615.95 & 529.41 & 3.0 & 22.26 \\
\hline & f1006_XL_3 & 615.98 & 529.12 & 3.0 & 20.4925 \\
\hline & f1011_XL_4 & 615.98 & 529.12 & 3.0 & 19.32 \\
\hline & & & & Mean & 20.59 \\
\hline 4.9 MW & F115_L_1 & 615.47 & 529.76 & 4.9 & 19.75 \\
\hline Low Forebay & f1110_L_2 & 615.71 & 530.01 & 4.9 & 18.38 \\
\hline \multirow[t]{9}{*}{$650 \mathrm{cfs}$} & F664_L_3 & 616.43 & 530.34 & 4.9 & 19.18 \\
\hline & f1002_L_4 & 616.43 & 530.34 & 4.9 & 18.42 \\
\hline & f1011_L_5 & 616.01 & 529.77 & 4.9 & 19.8 \\
\hline & f1011_L_6 & 615.95 & 529.64 & 4.9 & 19.6 \\
\hline & f1006_L_7 & 615.95 & 529.59 & 4.9 & 19.04 \\
\hline & f1011_L_8 & 615.95 & 529.43 & 4.9 & 18.56 \\
\hline & f1006_L_9 & 615.95 & 529.42 & 4.9 & 17.27 \\
\hline & f1011_L_10 & 615.95 & 529.42 & 4.9 & 19.96 \\
\hline & & & & Mean & 19.00 \\
\hline $6.0 \mathrm{MW}$ & f1011_m_1 & 615.23 & 529.87 & 6.0 & 15.95 \\
\hline Low Forebay & f900_m_2 & 615.38 & 529.76 & 6.0 & 18.85 \\
\hline \multirow[t]{5}{*}{$820 \mathrm{cfs}$} & f1015_m_3 & 615.47 & 529.76 & 6.0 & 17.96 \\
\hline & f901_m_4 & 615.47 & 529.76 & 6.0 & 15.7 \\
\hline & f900_m_5 & 615.44 & 529.65 & 6.0 & 15.66 \\
\hline & f1015_m_6 & 615.65 & 529.7 & 6.0 & 13.74 \\
\hline & & & & Mean & 16.31 \\
\hline $7.0 \mathrm{MW}$ & f1011_H_1 & 616.1 & 530.13 & 7.0 & 17.42 \\
\hline Low Forebay & f1011_H_3 & 616.1 & 530.1 & 7.0 & 16.41 \\
\hline \multirow[t]{4}{*}{1150 cfs } & f1011_H_4 & 616.1 & 530.09 & 7.0 & 13.68 \\
\hline & f1011_H_5 & 616.1 & 530.12 & 7.0 & 13.57 \\
\hline & f1011_H_6 & 616.1 & 530.07 & 7.0 & 14.26 \\
\hline & & & & Mean & 15.07 \\
\hline
\end{tabular}




\begin{tabular}{|c|c|c|c|c|c|}
\hline Test Condition & File Name & $\begin{array}{c}\text { Forebay } \\
\text { Elevation } \\
\text { (ft MSL) }\end{array}$ & $\begin{array}{l}\text { Tailwater } \\
\text { Elevation } \\
\text { (ft MSL) }\end{array}$ & $\begin{array}{c}\text { Turbine } \\
\text { MW }\end{array}$ & $\begin{array}{l}\text { Nadir } \\
\text { (psia) }\end{array}$ \\
\hline \multicolumn{6}{|c|}{ High Forebay - $634 \mathrm{ft}$ MSL } \\
\hline $4.9 \mathrm{MW}$ & f115_h_4_1 & 633.59 & 526.06 & 4.9 & 17.66 \\
\hline High forebay & f699_h_4_2 & 633.59 & 526.06 & 4.9 & 17.13 \\
\hline \multirow[t]{7}{*}{$650 \mathrm{cfs}$} & $\mathrm{f} 223 \_4 \_3$ & 633.59 & 526.06 & 4.9 & 17.907 \\
\hline & f250_4_4 & 633.59 & 526.06 & 4.9 & 19.24 \\
\hline & $\mathrm{f} 272 \_4 \_5$ & 633.59 & 526.06 & 4.9 & 16.72 \\
\hline & $\mathrm{f} 221 \_4 \_6$ & 633.59 & 526.06 & 4.9 & 17.92 \\
\hline & f202_4_7 & 633.59 & 526.06 & 4.9 & 16.59 \\
\hline & f239_4_8 & 633.59 & 526.06 & 4.9 & 17.33 \\
\hline & & & & Mean & 17.56 \\
\hline $6.5 \mathrm{MW}$ & f115_h_6-5_1 & 634.13 & 526.26 & 6.5 & 15.84 \\
\hline High forebay & f244_h_6_2 & 634.13 & 526.26 & 6.5 & 16.61 \\
\hline \multirow[t]{7}{*}{$820 \mathrm{cfs}$} & f202_h_6_3 & 634.13 & 526.26 & 6.5 & 18.77 \\
\hline & f244_6_5 & 633.56 & 526.21 & 6.5 & 17.41 \\
\hline & f252_6_6 & 633.56 & 526.21 & 6.5 & 16.59 \\
\hline & f213_6_7 & 633.56 & 526.21 & 6.5 & 16.57 \\
\hline & f248_6_8 & 633.56 & 526.21 & 6.5 & 15.69 \\
\hline & f224_6_9 & 633.56 & 526.21 & 6.5 & 17.36 \\
\hline & & & & Mean & 16.86 \\
\hline $9.0 \mathrm{MW}$ & f664_h_9_1 & 633.62 & 526.5 & 9.0 & 13.71 \\
\hline High forebay & f1110_h_9_2 & 633.62 & 526.5 & 9.0 & 14.33 \\
\hline \multirow[t]{7}{*}{$1150 \mathrm{cfs}$} & f207_9_3 & 633.62 & 526.5 & 9.0 & 14.77 \\
\hline & f204_9_5 & 633.62 & 526.5 & 9.0 & 14.96 \\
\hline & f214_9_6 & 633.62 & 526.5 & 9.0 & 15.046 \\
\hline & f266_9_7 & 633.62 & 526.5 & 9.0 & 15.079 \\
\hline & f231_9_8 & 633.62 & 526.5 & 9.0 & 14.659 \\
\hline & f267_9_9 & 633.62 & 526.5 & 9.0 & 14.868 \\
\hline & & & & Mean & 14.68 \\
\hline
\end{tabular}




\section{Sensor Fish Turbine Passage - Pressure Rate of Change through the Runner}




\begin{tabular}{|c|c|c|c|c|}
\hline Test Condition & File Name & $\begin{array}{l}\text { Rate of } \\
\text { Change } \\
\end{array}$ & $\begin{array}{c}\text { Pressure at } \\
0.05 \mathrm{~s} \\
\text { (psia) } \\
\end{array}$ & $\begin{array}{c}\text { Pressure at } 0 \mathrm{~s} \\
(\mathrm{psia})\end{array}$ \\
\hline \multicolumn{5}{|l|}{ Forebay $-616 \mathrm{ft}$ MSL } \\
\hline $2.8 \mathrm{MW}-540 \mathrm{cfs}$ & f114_L_2 & -389.6 & 40.59 & 21.11 \\
\hline Low Forebay & f635_L_3 & -512.4 & 46.74 & 21.12 \\
\hline $3.0 \mathrm{MW}-550 \mathrm{cfs}$ & f1006_XL_1 & -309.06 & 34.93 & 19.48 \\
\hline \multirow[t]{6}{*}{ Low Forebay } & f1110_XL_2 & -455 & 45.01 & 22.26 \\
\hline & f1006_XL_3 & -384.03 & 39.67 & 20.47 \\
\hline & f1011_XL_4 & -422.8 & 40.58 & 19.44 \\
\hline & Mean & -412.15 & & \\
\hline & StDev & 69.18 & & \\
\hline & SE & 28.24 & & \\
\hline $4.9 \mathrm{MW}$ & F115_L_1 & -475.2 & 43.56 & 19.8 \\
\hline Low Forebay & f1110_L_2 & -606 & 48.41 & 18.11 \\
\hline \multirow[t]{11}{*}{$650 \mathrm{cfs}$} & F664_L_3 & -502.4 & 44.57 & 19.45 \\
\hline & f1002_L_4 & -542.322 & 46.33 & 19.21 \\
\hline & f1011_L_5 & -499.4 & 44.51 & 19.54 \\
\hline & f1011_L_6 & -451 & 41.99 & 19.44 \\
\hline & f1006_L_7 & -533.46 & 46.15 & 19.48 \\
\hline & f1011_L_8 & -604.2 & 48.74 & 18.53 \\
\hline & f1006_L_9 & -707.88 & 53.1 & 17.7 \\
\hline & f1011_LL_10 & -515.4 & 45.31 & 19.54 \\
\hline & Mean & -543.73 & & \\
\hline & StDev & 76.27 & & \\
\hline & SE & 24.12 & & \\
\hline $6.0 \mathrm{MW}$ & f1011_m_1 & -582 & 44.41 & 15.31 \\
\hline Low Forebay & f900_m_2 & -455.8 & 41.96 & 19.17 \\
\hline \multirow[t]{7}{*}{820 cfs } & f1015_m_3 & -579.474 & 45.65 & 16.68 \\
\hline & f901_m_4 & -621.4 & 46.54 & 15.47 \\
\hline & f900_m_5 & -607.8 & 46.36 & 15.97 \\
\hline & $\mathrm{f} 1015 \_\mathrm{m} \_6$ & -624.442 & 47.39 & 16.17 \\
\hline & Mean & -578.49 & & \\
\hline & StDev & 63.05 & & \\
\hline & SE & 25.74 & & \\
\hline $7.0 \mathrm{MW}$ & f1011_H_1 & -559.8 & 45.01 & 17.02 \\
\hline Low Forebay & f1011_H_3 & -469.2 & 39.58 & 16.12 \\
\hline \multirow[t]{6}{*}{1150 cfs } & f1011_H_4 & -638.4 & 45.52 & 13.6 \\
\hline & f1011_H_5 & -632.2 & 45.11 & 13.5 \\
\hline & f1011_H_6 & -596.2 & 44.01 & 14.2 \\
\hline & Mean & -579.16 & & \\
\hline & StDev & 69.06 & & \\
\hline & SE & 30.89 & & \\
\hline
\end{tabular}




\begin{tabular}{|c|c|c|c|c|}
\hline Test Condition & File Name & $\begin{array}{l}\text { Rate of } \\
\text { Change } \\
\end{array}$ & $\begin{array}{c}\text { Pressure at - } \\
0.05 \mathrm{~s} \\
\text { (psia) }\end{array}$ & $\begin{array}{c}\text { Pressure at } 0 \mathrm{~s} \\
(\mathrm{psia})\end{array}$ \\
\hline \multicolumn{5}{|l|}{ Forebay $634 \mathrm{ft}$ MSL } \\
\hline $4.9 \mathrm{MW}$ & f115_h_4_1 & -661 & 50.65 & 17.6 \\
\hline High forebay & f699_h_4_2 & -662.8 & 49.98 & 16.84 \\
\hline \multirow[t]{9}{*}{$650 \mathrm{cfs}$} & f223_4_3 & -653.42 & 36.178 & 3.507 \\
\hline & f250_4_4 & -323.42 & 21.01 & 4.839 \\
\hline & f272_4_5 & -684.26 & 36.532 & 2.319 \\
\hline & f221_4_6 & -499.04 & 28.47 & 3.518 \\
\hline & f202_4_7 & -690.96 & 36.738 & 2.19 \\
\hline & f239_4_8 & -367.16 & 24.834 & 6.476 \\
\hline & Mean & $\begin{array}{l}-567.8 \\
\end{array}$ & & \\
\hline & StDev & 150.5 & & \\
\hline & SE & 53.20 & & \\
\hline $6.5 \mathrm{MW}$ & f115_h_6-5_1 & -707 & 50.84 & 15.49 \\
\hline High forebay & f244_h_6_2 & -380.84 & 25.861 & 6.819 \\
\hline \multirow[t]{9}{*}{820 cfs } & f202_h_6_3 & -533.32 & 31.036 & 4.37 \\
\hline & f244_6_5 & -641.4 & 35.081 & 3.011 \\
\hline & f252_6_6 & -672.6 & 35.82 & 2.19 \\
\hline & f213_6_7 & -689.16 & 36.625 & 2.167 \\
\hline & f248_6_8 & -678.62 & 35.223 & 1.292 \\
\hline & f224_6_9 & -493.48 & 27.63 & 2.956 \\
\hline & Mean & -599.6 & & \\
\hline & StDev & 117.3 & & \\
\hline & SE & 41.49 & & \\
\hline $9.0 \mathrm{MW}$ & f664_h_9_1 & -680 & 47.86 & 13.86 \\
\hline High forebay & f1110_h_9_2 & -599.6 & 44 & 14.02 \\
\hline \multirow[t]{9}{*}{1150 cfs } & f207_9_3 & -589.04 & 29.815 & 0.363 \\
\hline & f204_9_5 & -582.9 & 29.699 & 0.554 \\
\hline & f214_9_6 & -531.76 & 27.224 & 0.636 \\
\hline & f266_9_7 & -531.7 & 27.254 & 0.669 \\
\hline & f231_9_8 & -656.72 & 33.085 & 0.249 \\
\hline & f267_9_9 & -429.88 & 21.952 & 0.458 \\
\hline & Mean & -575.2 & & \\
\hline & StDev & 78.7 & & \\
\hline & SE & 27.8 & & \\
\hline
\end{tabular}


Appendix C

\section{Pressure and Acceleration Magnitude Time Histories for Each Sensor Fish Release}




\section{Sensor Fish Weir Passage - Low-Forebay Elevation (616 ft MSL) Juvenile Pipe}



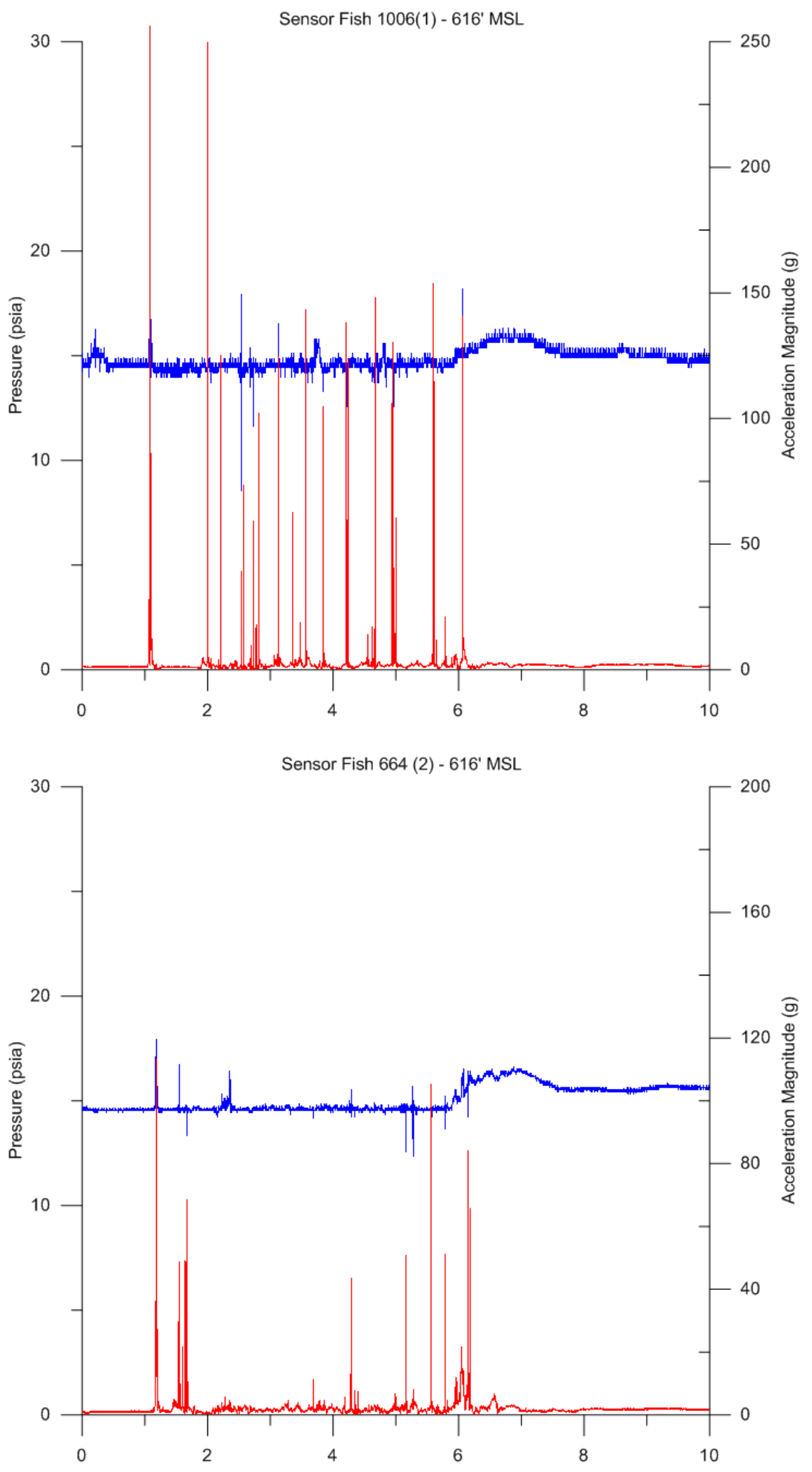

C. 3 

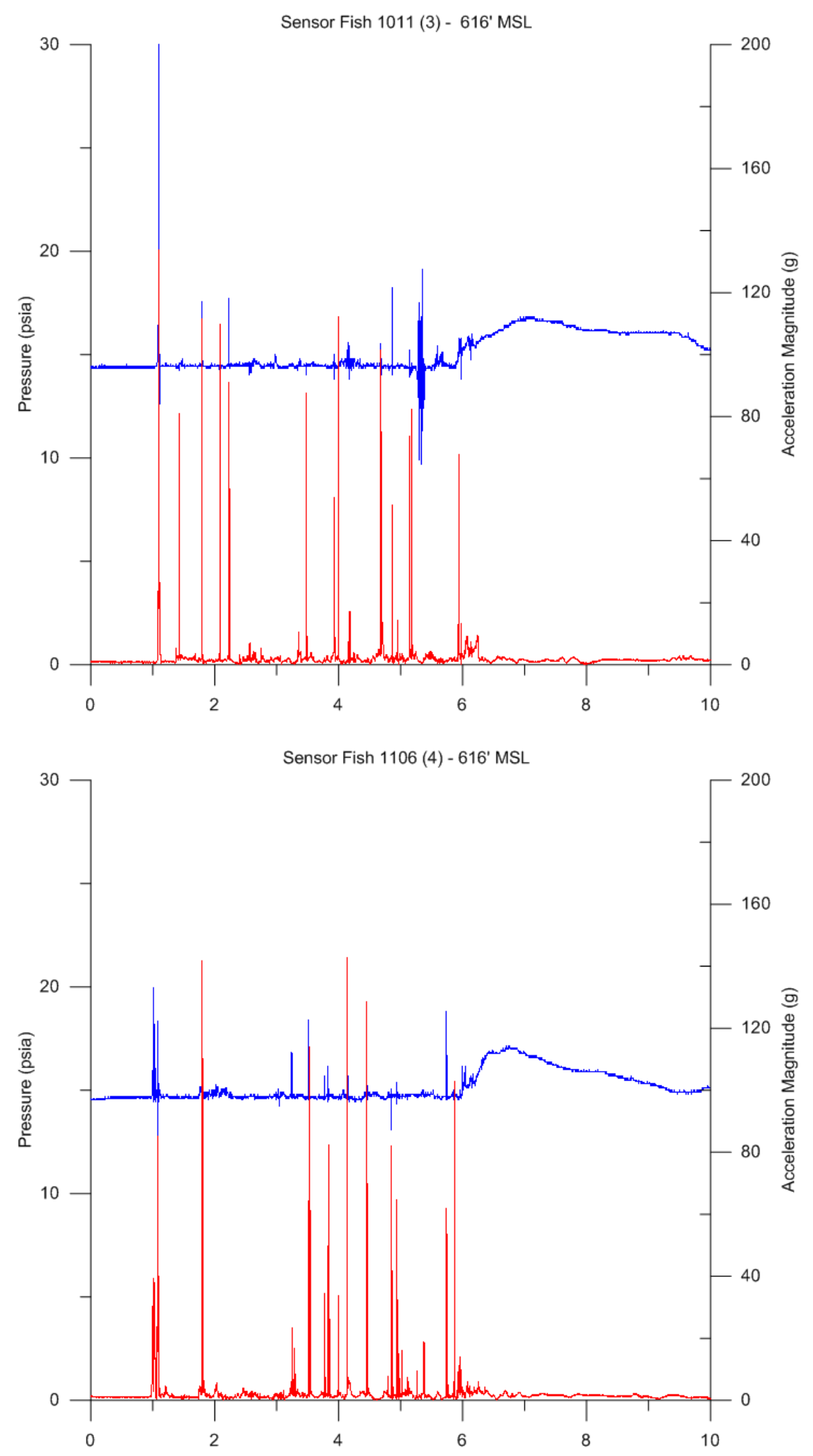

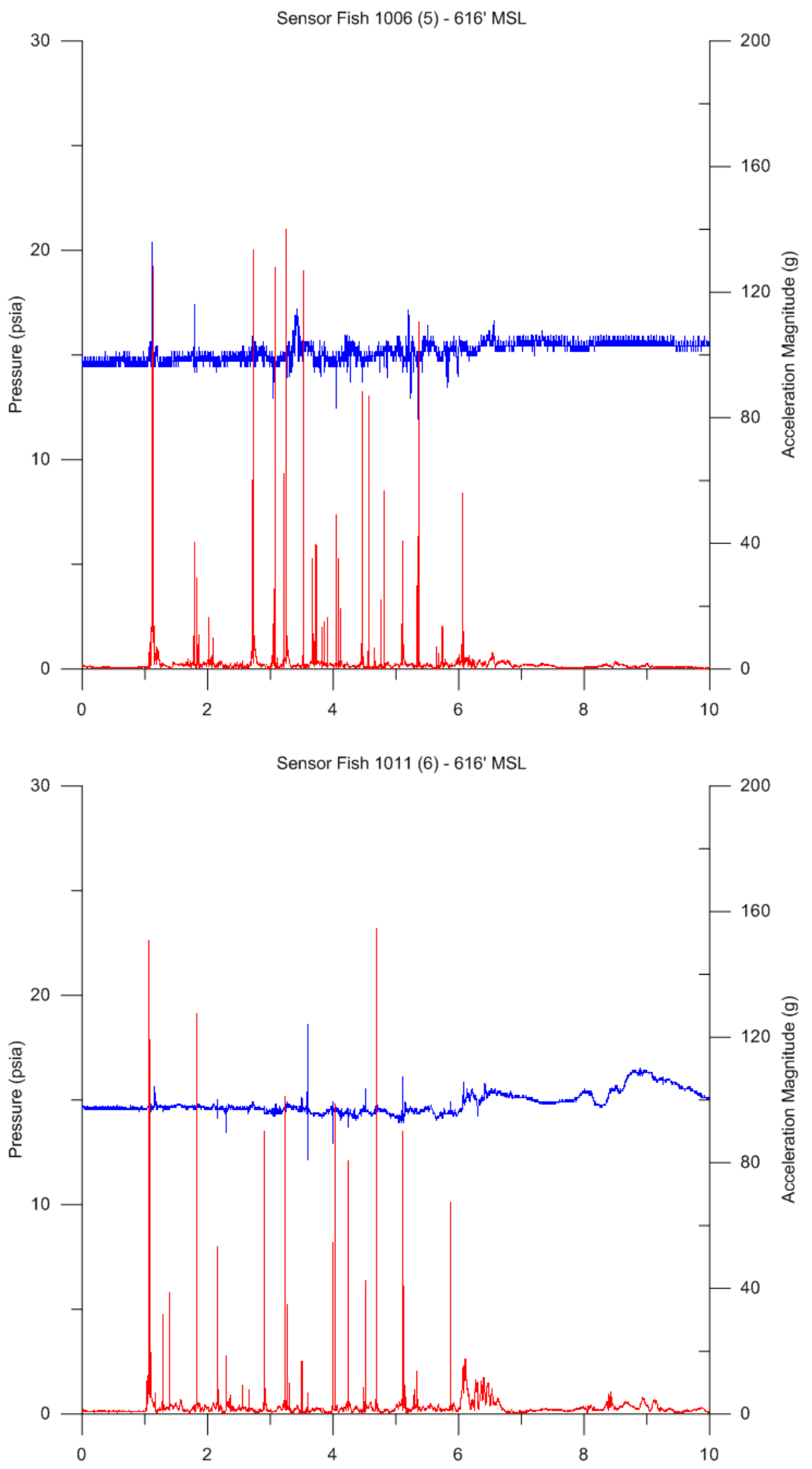

C. 5 

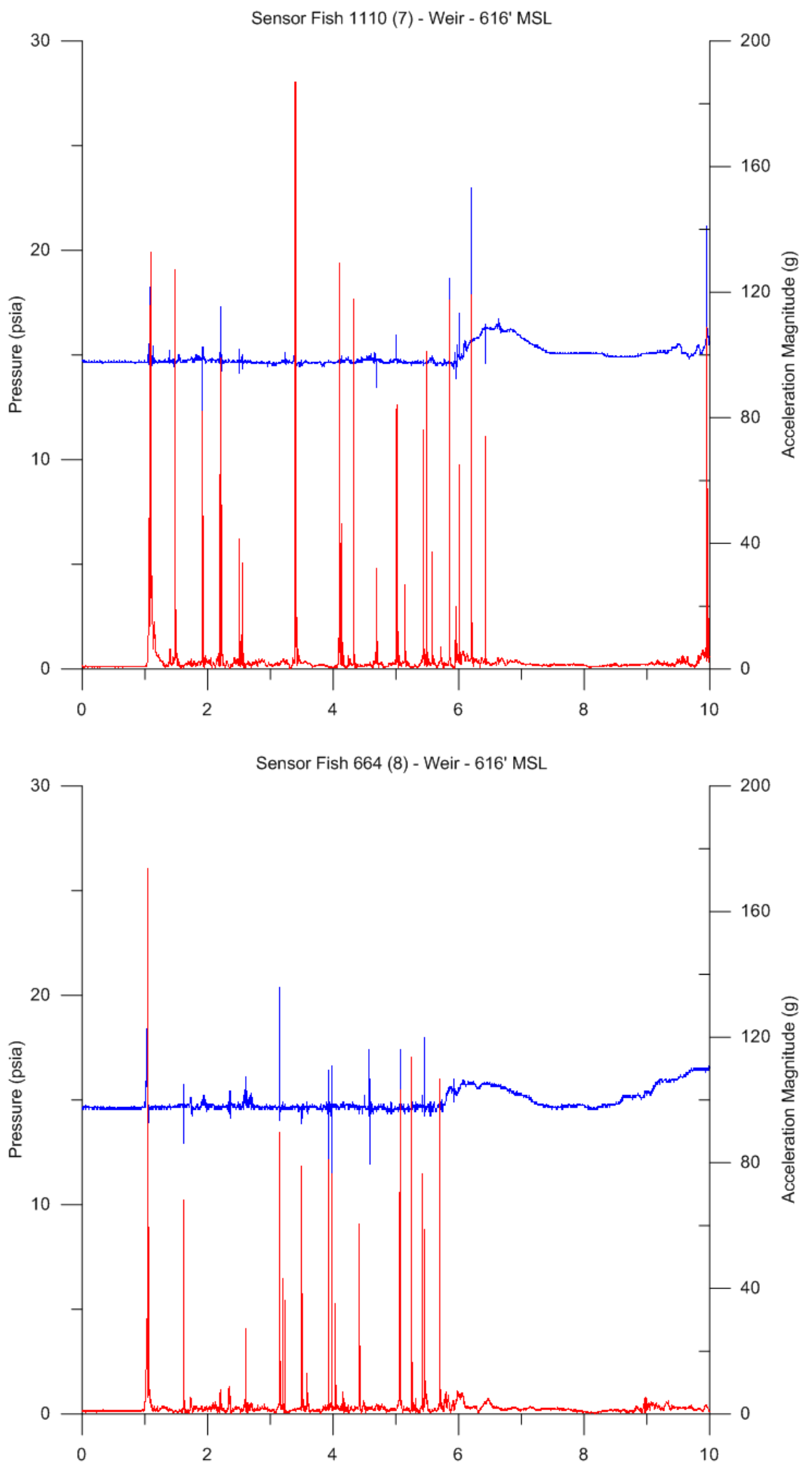

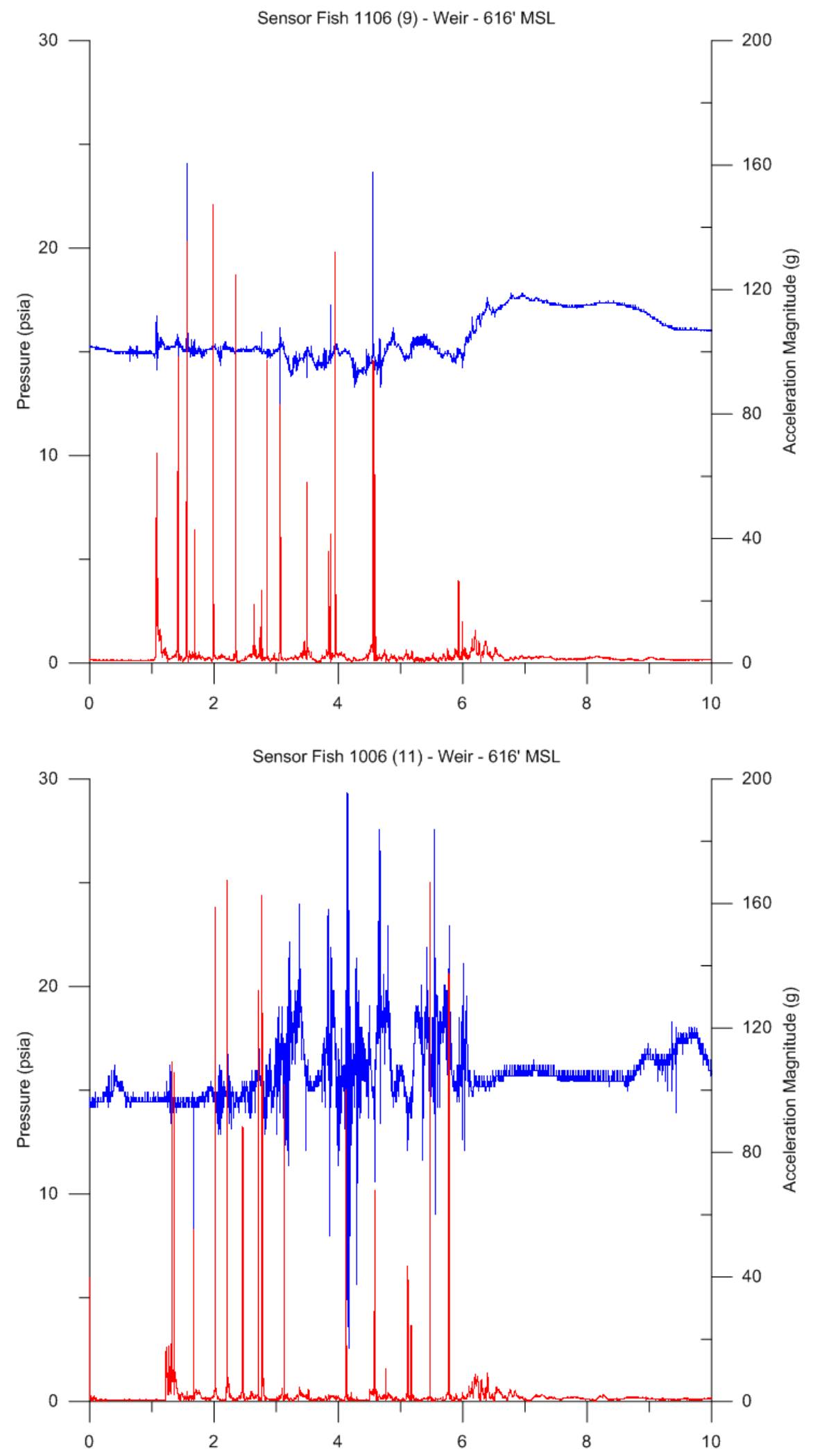

C.7 

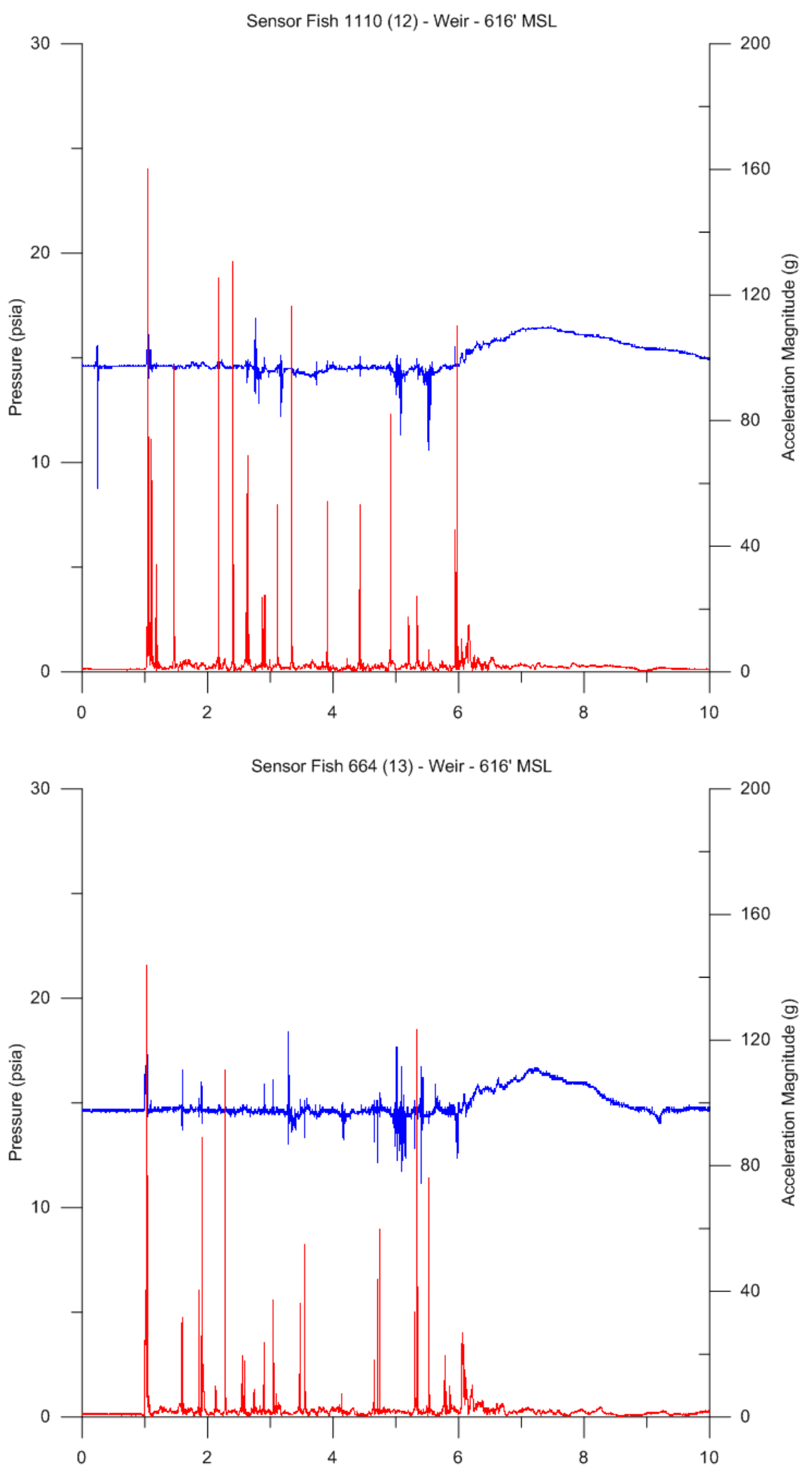

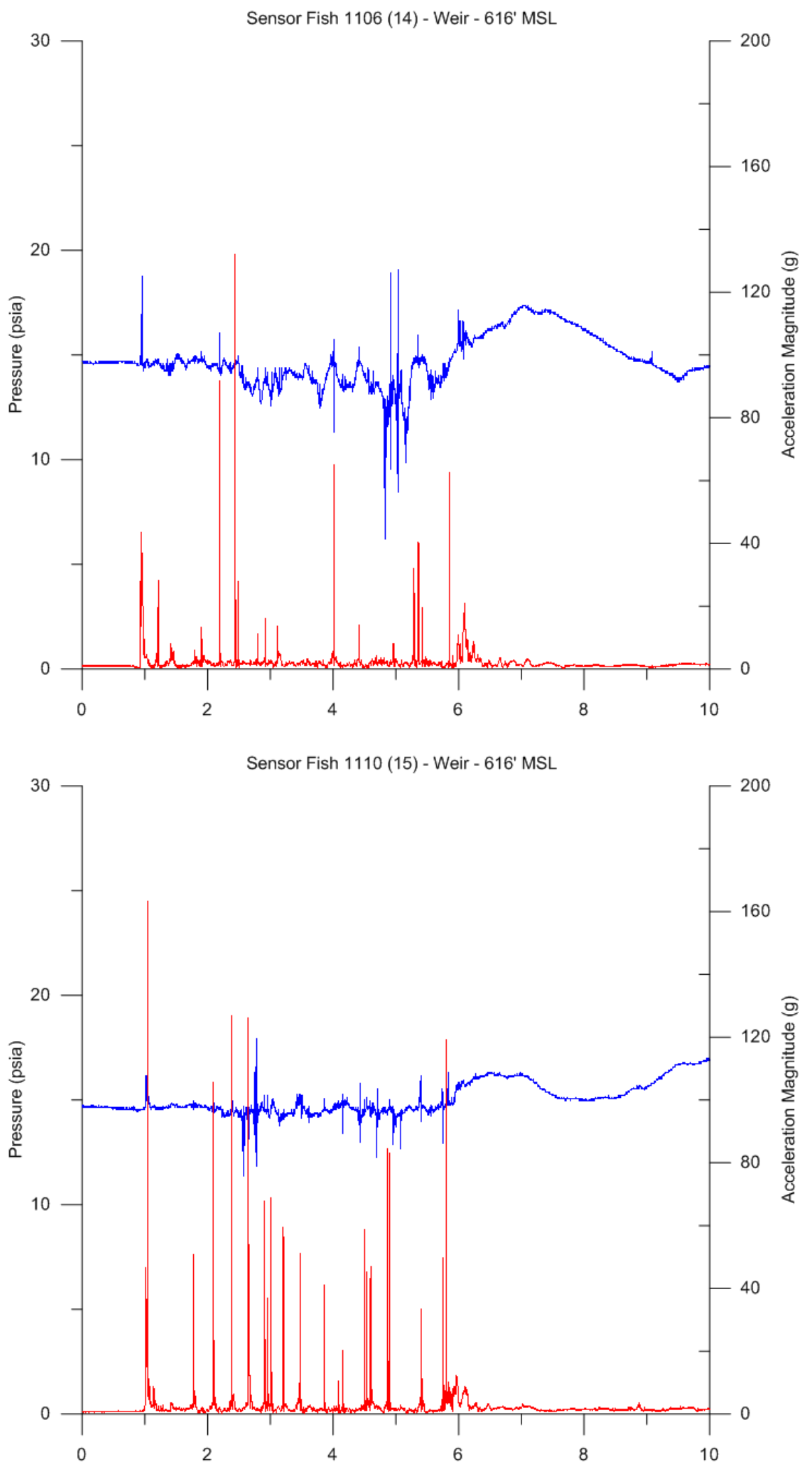

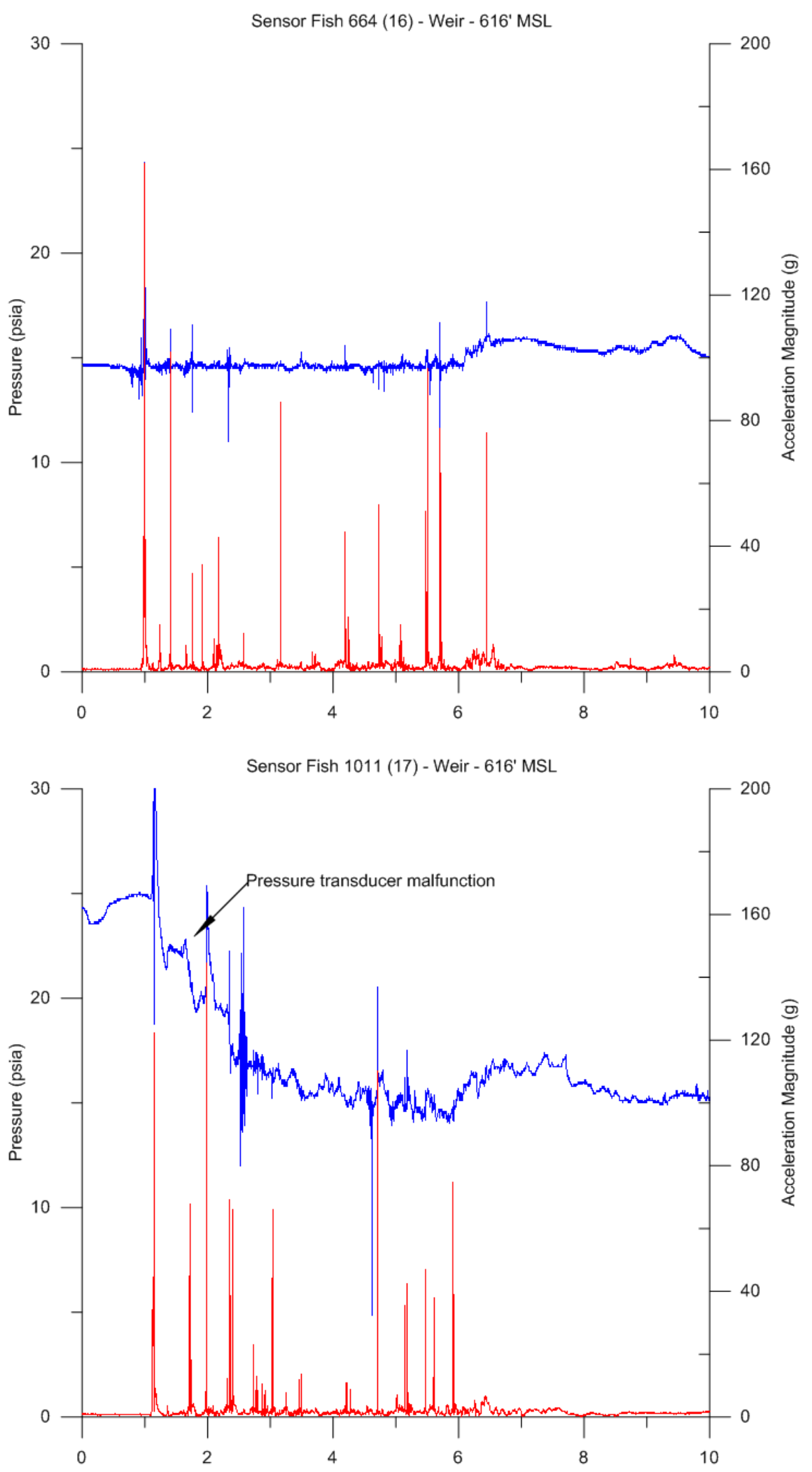
Sensor Fish Weir Passage Low-Forebay Elevation (616 ft MSL) Adult Pipe 

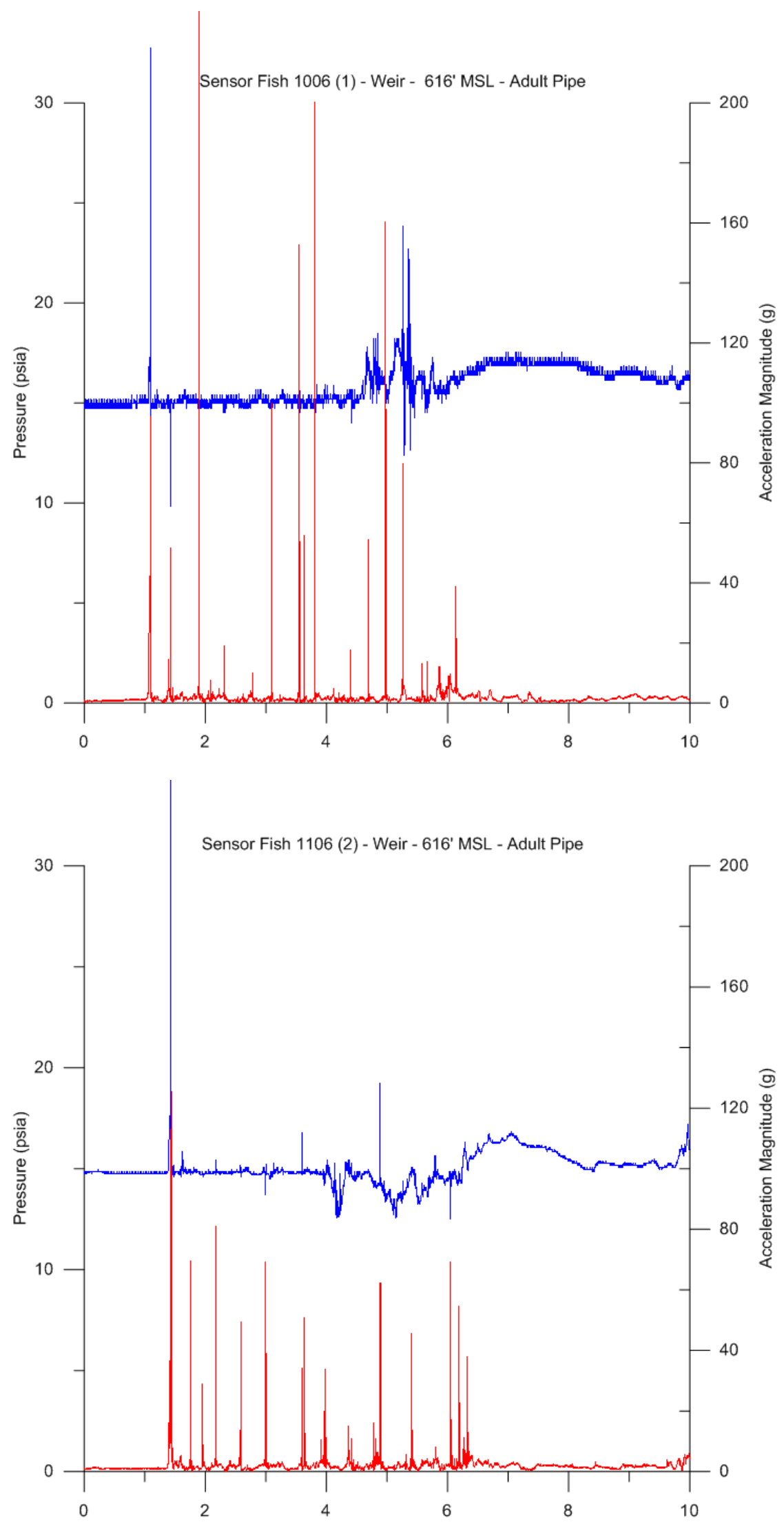


\section{Sensor Fish Weir Passage - High-Forebay Elevation (634 ft MSL) Juvenile Pipe}



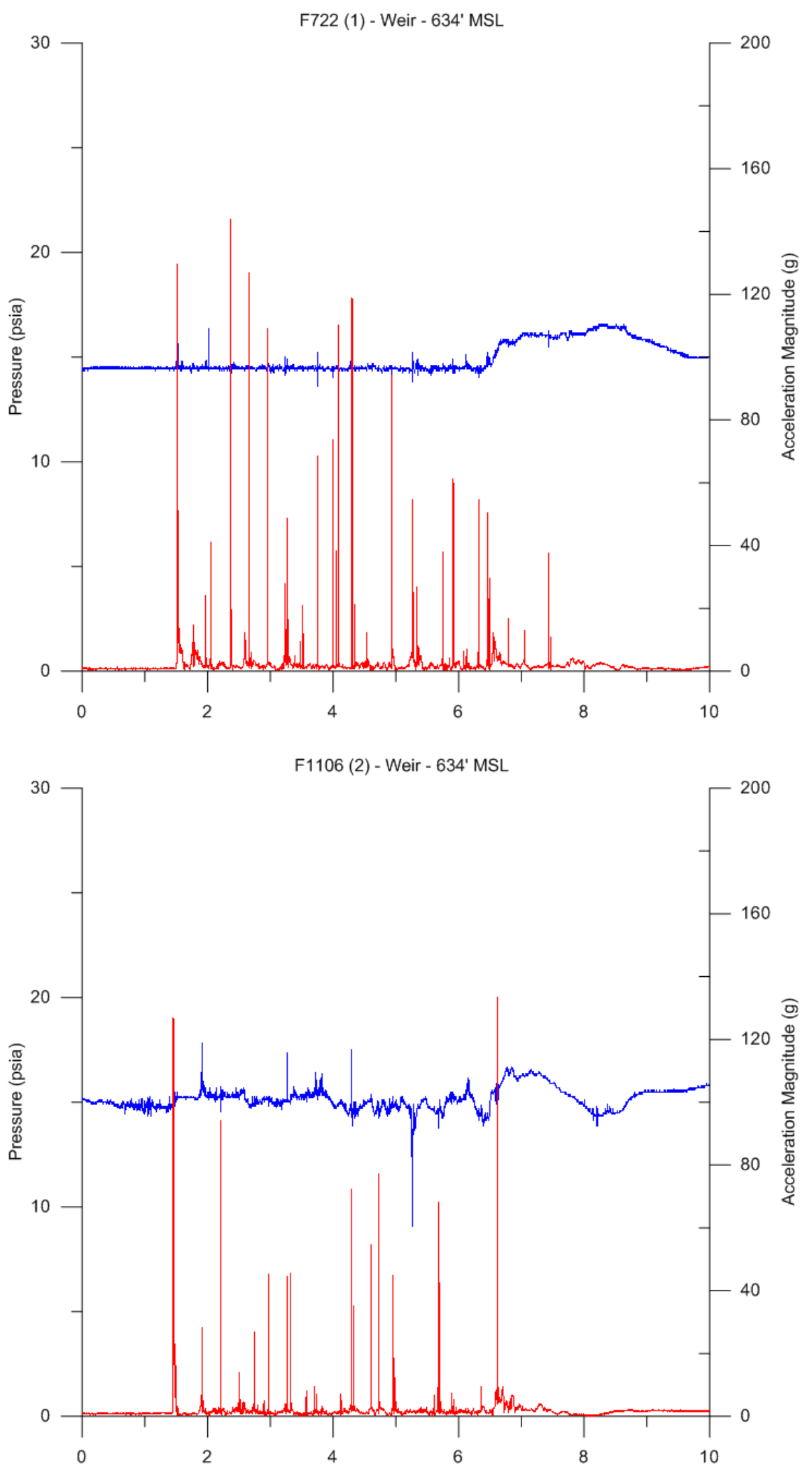

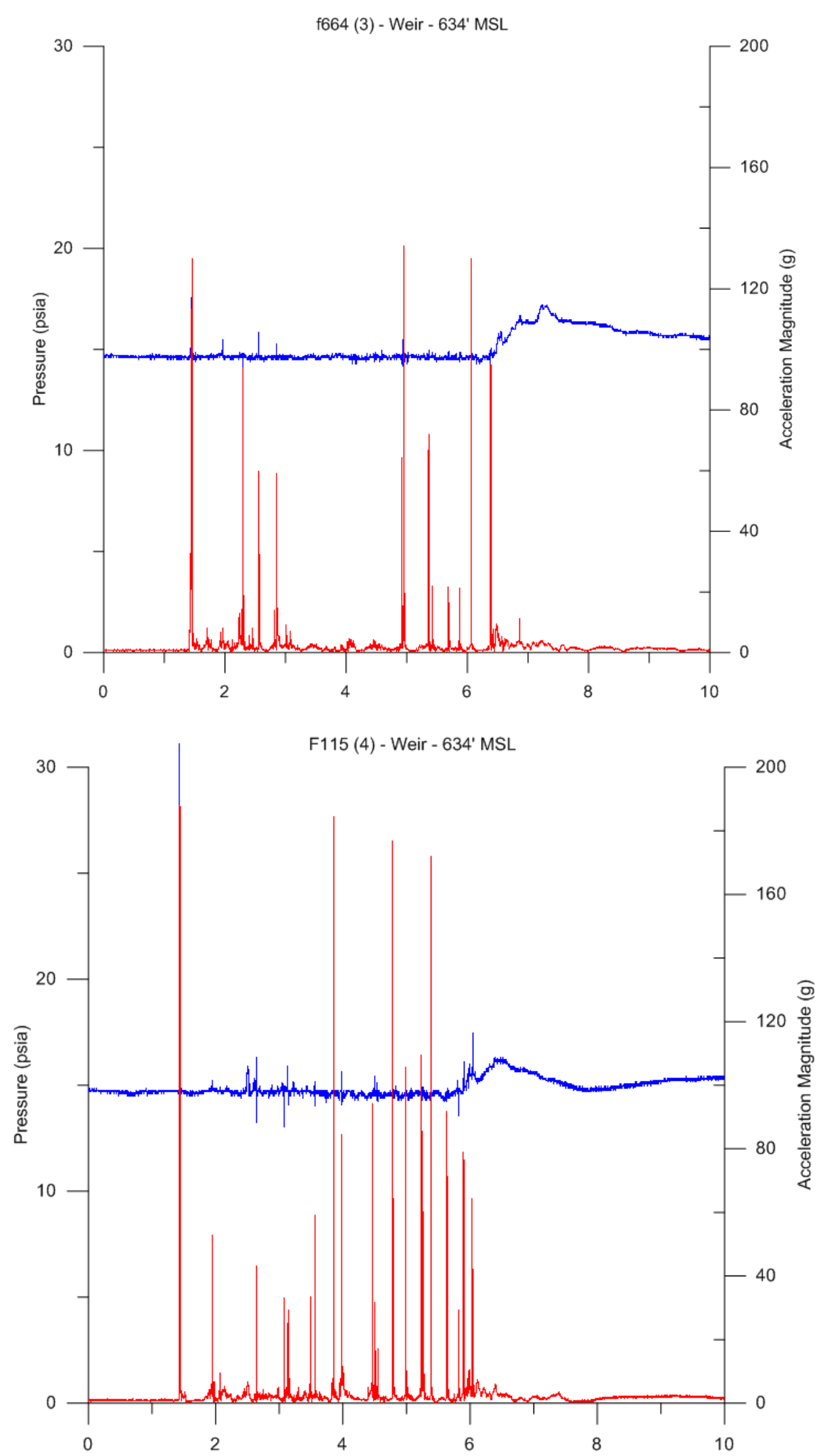

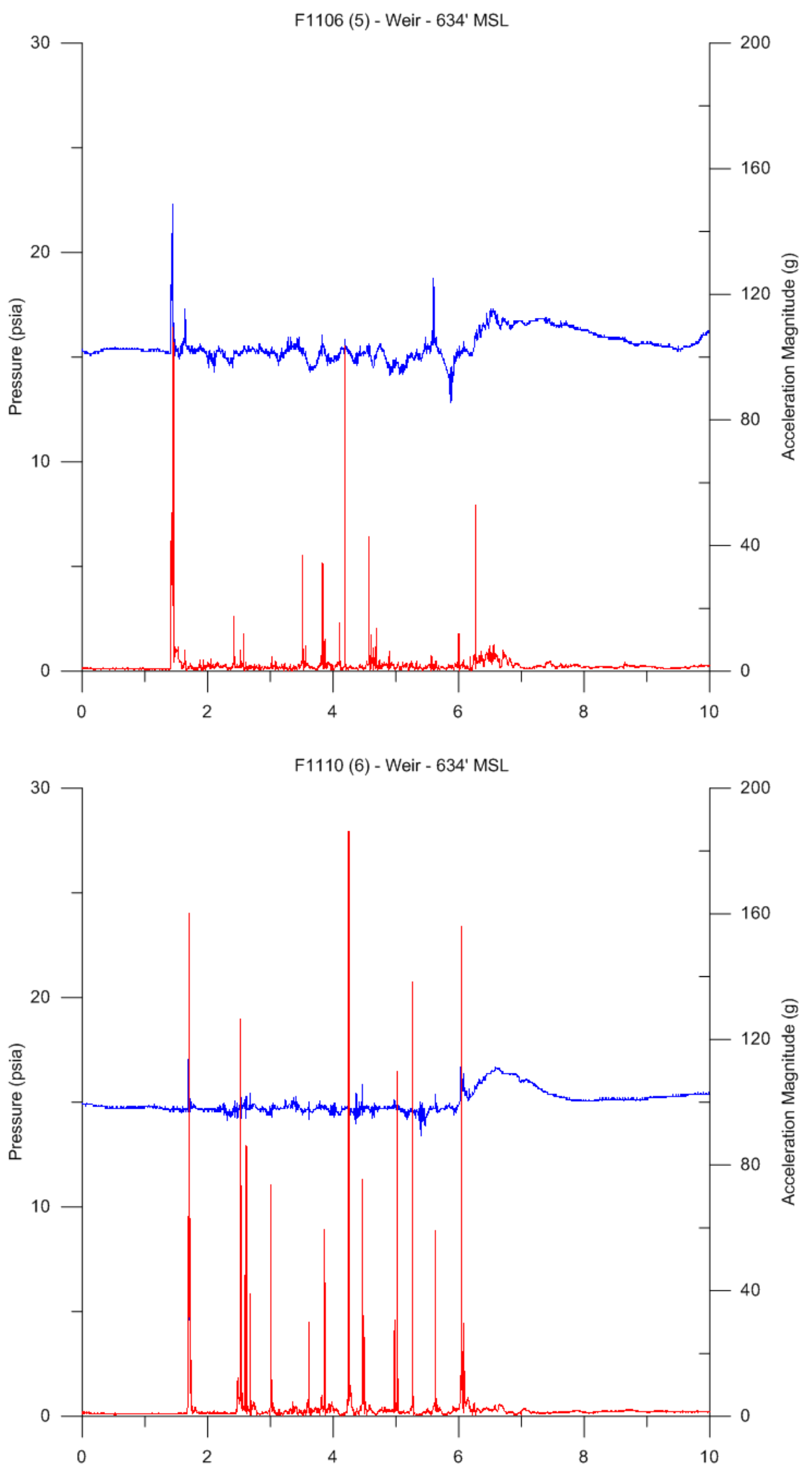

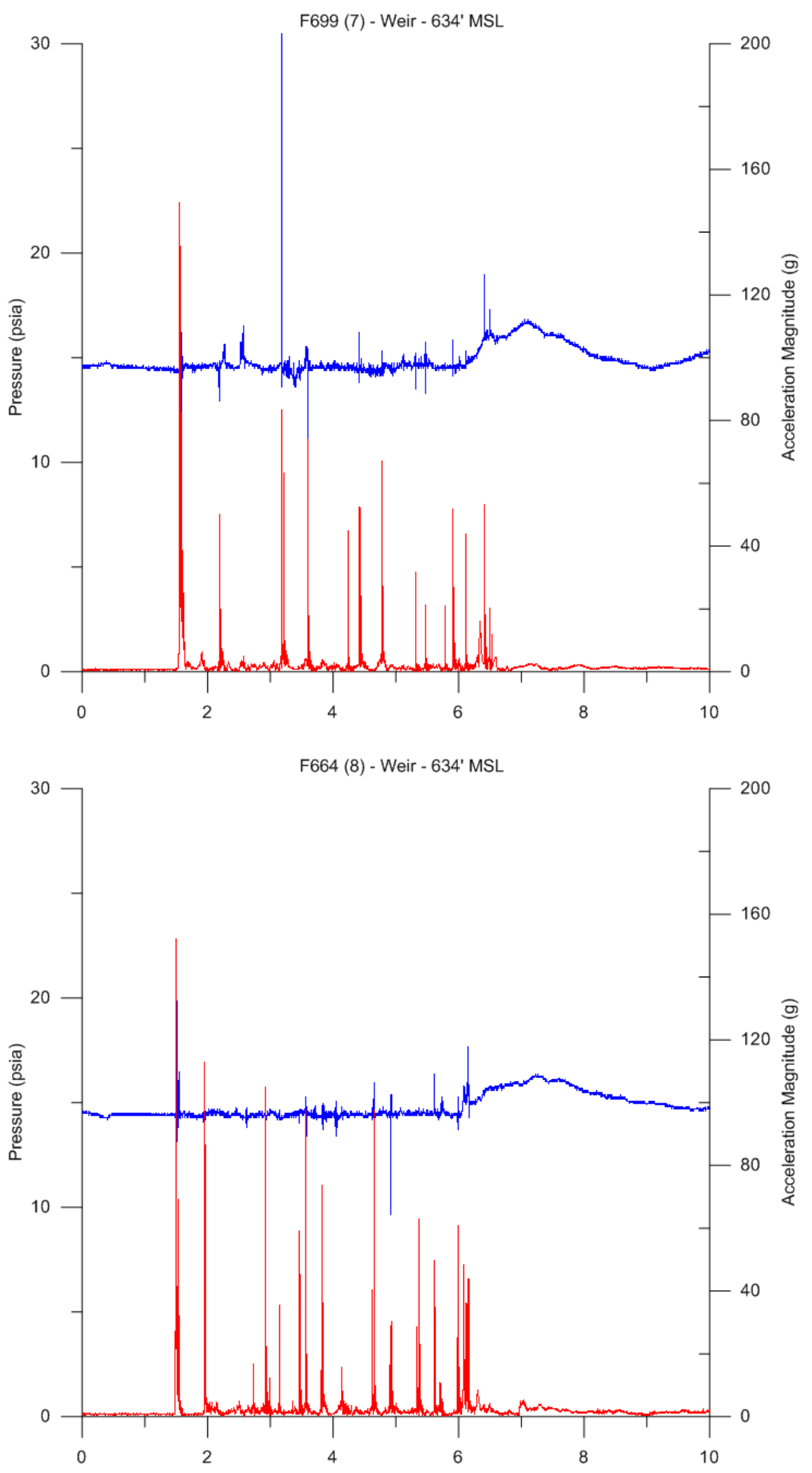

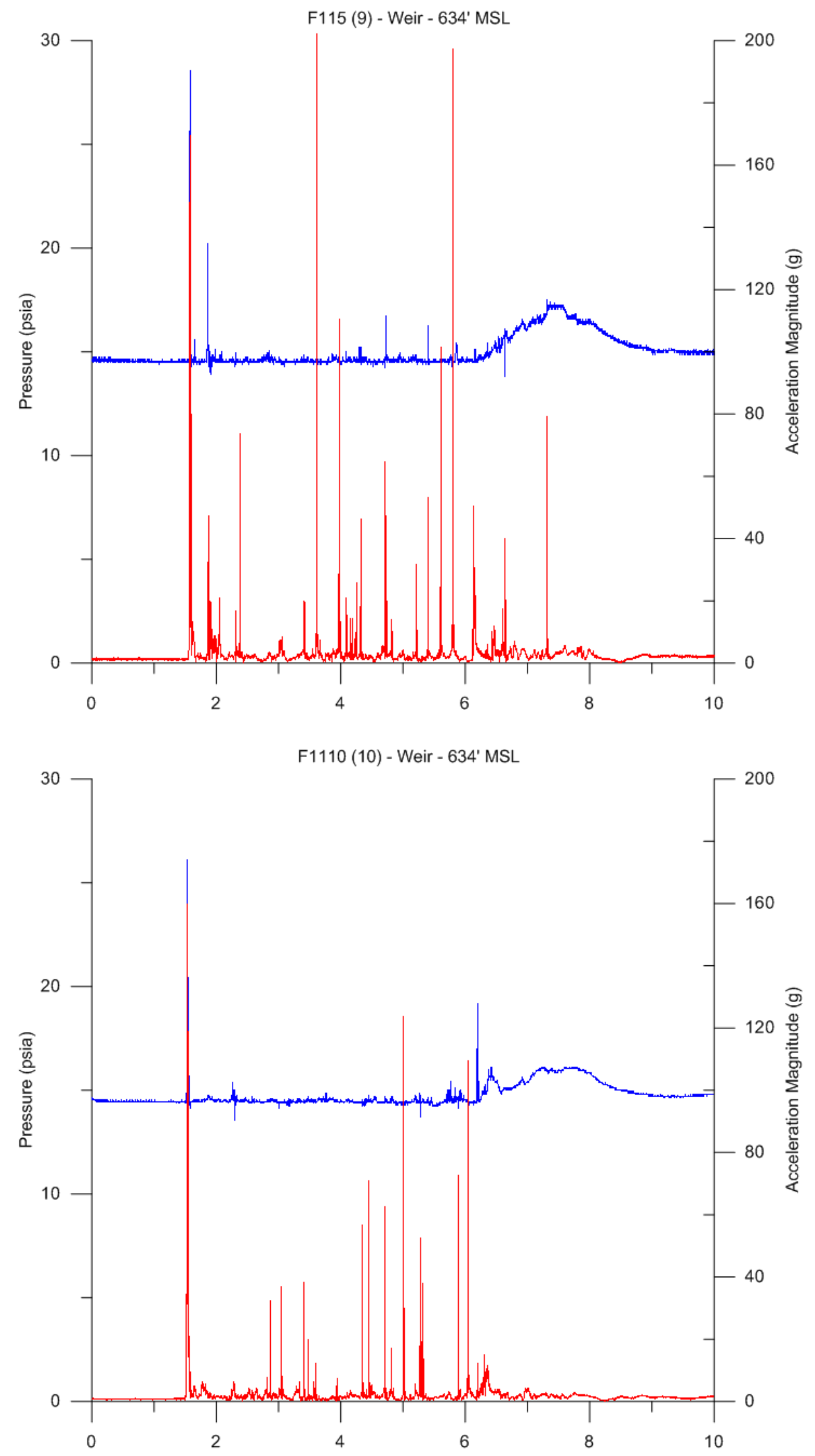

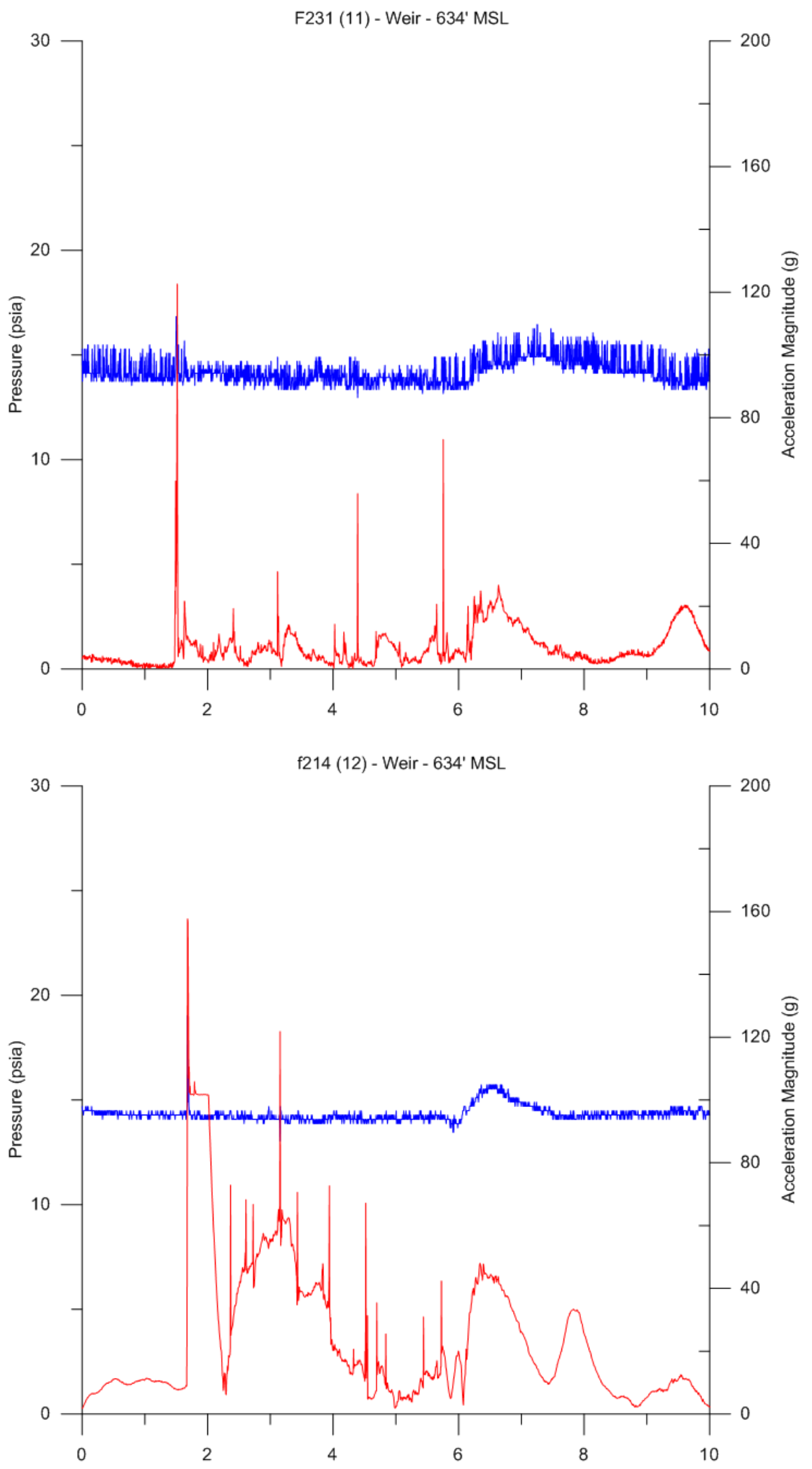

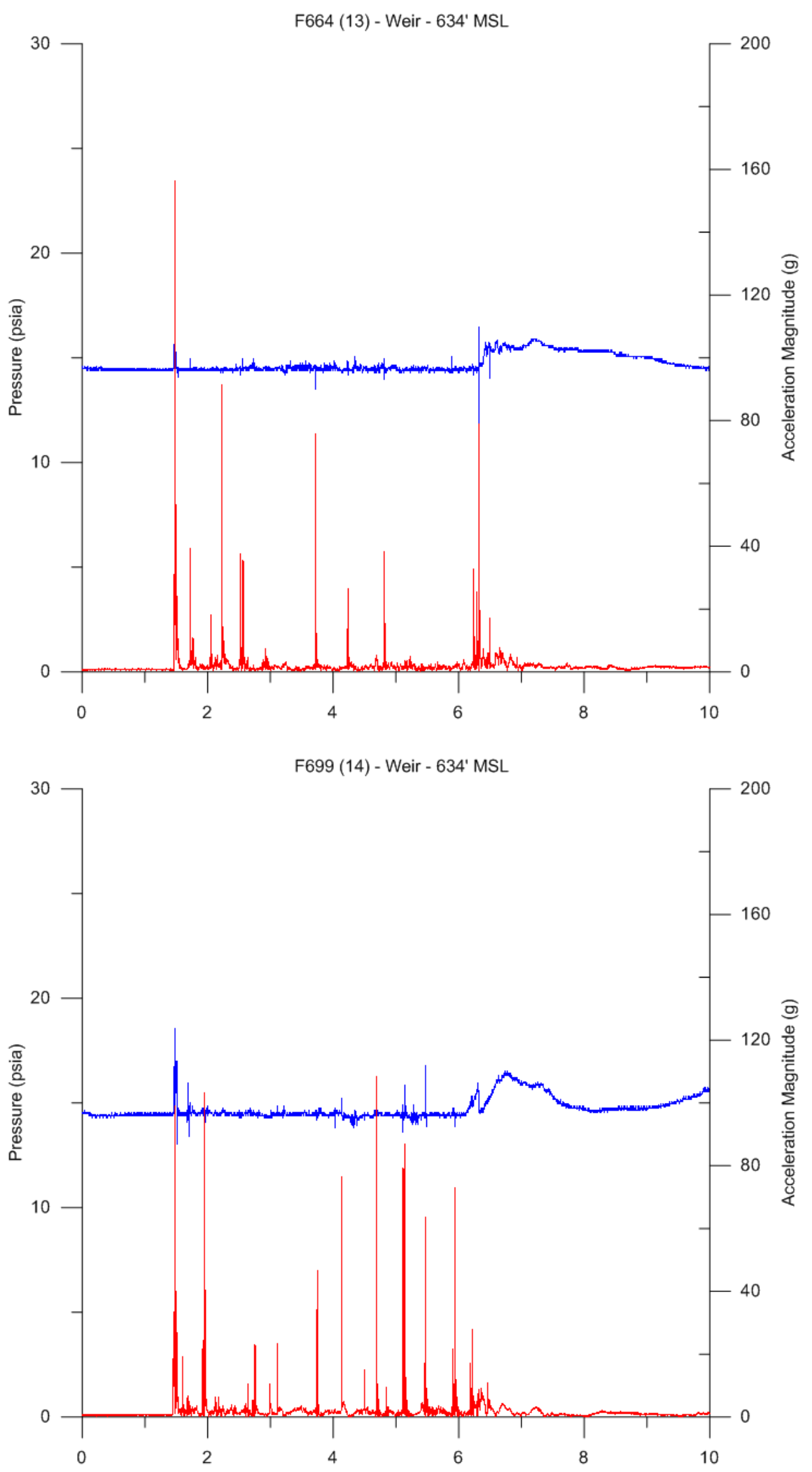



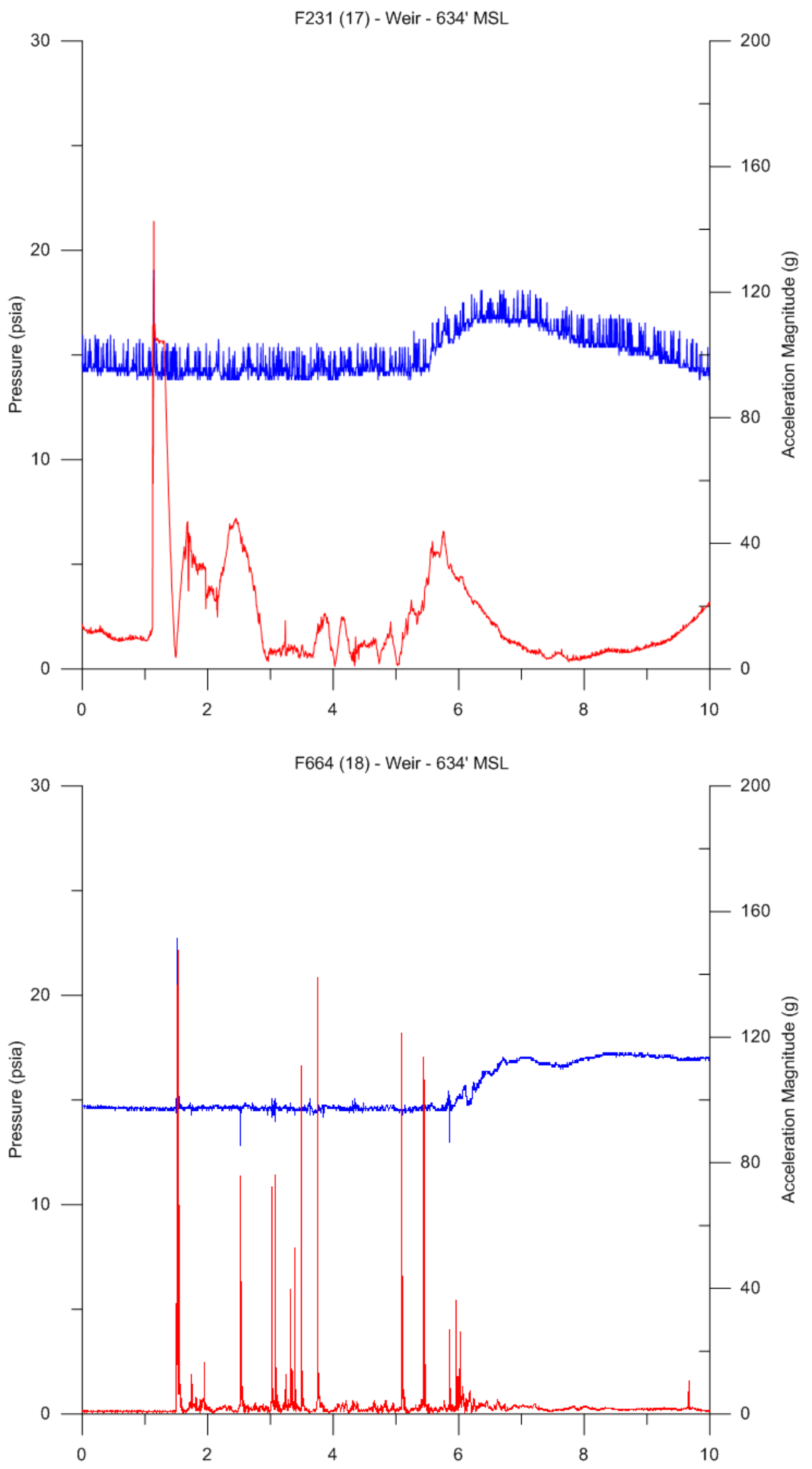


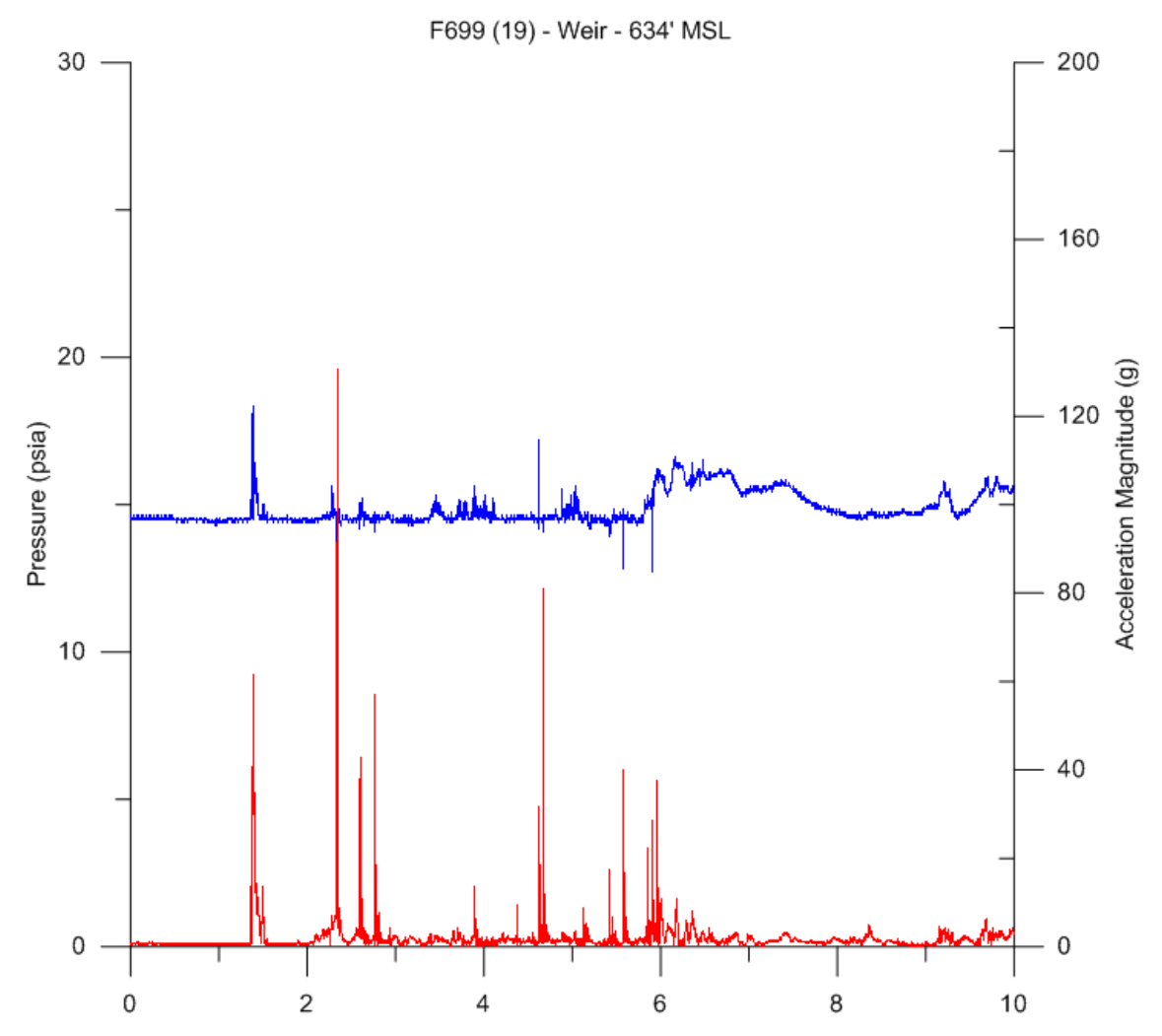




\section{Sensor Fish Weir Passage -} High-Forebay Elevation (634 ft MSL) Adult Pipe 

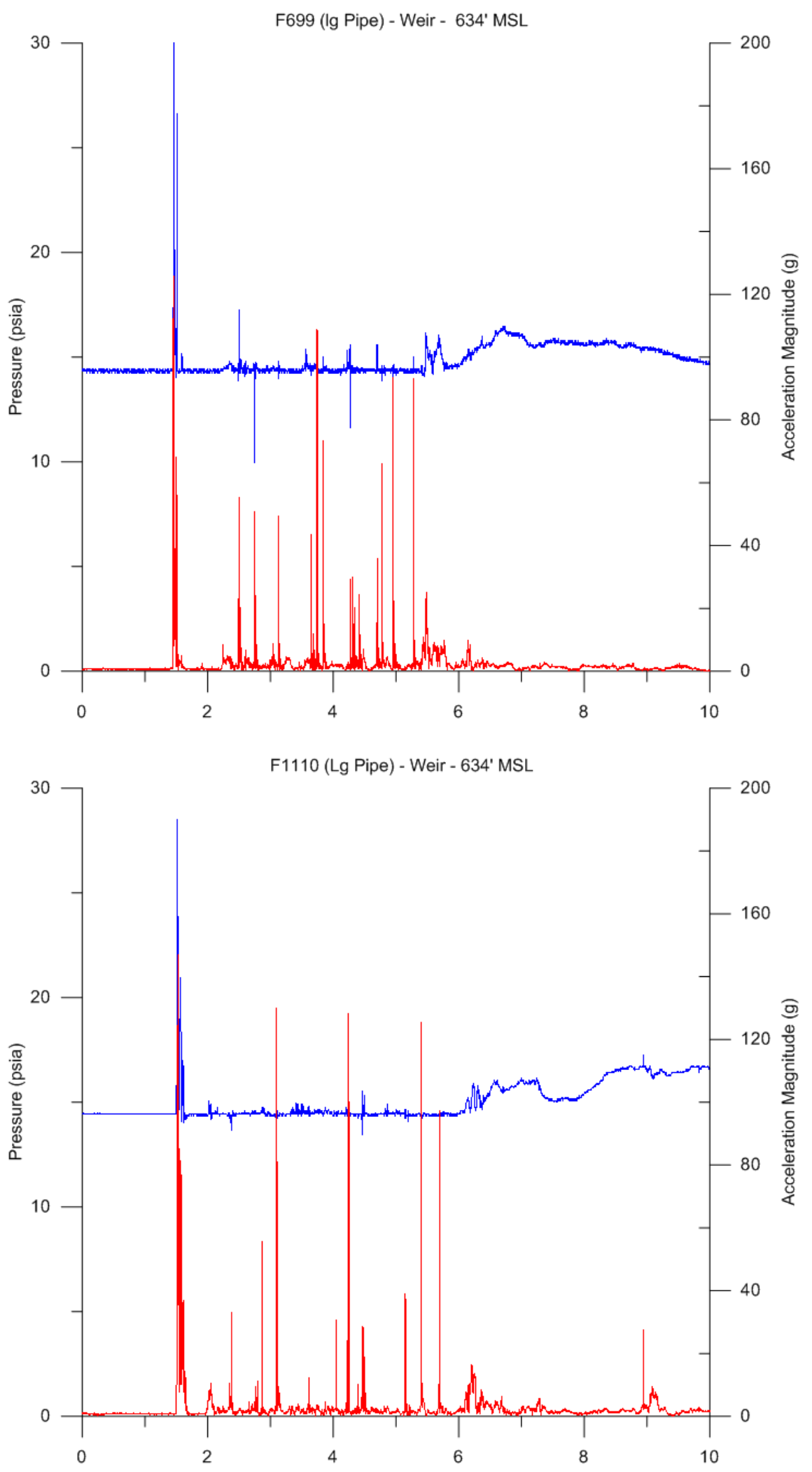

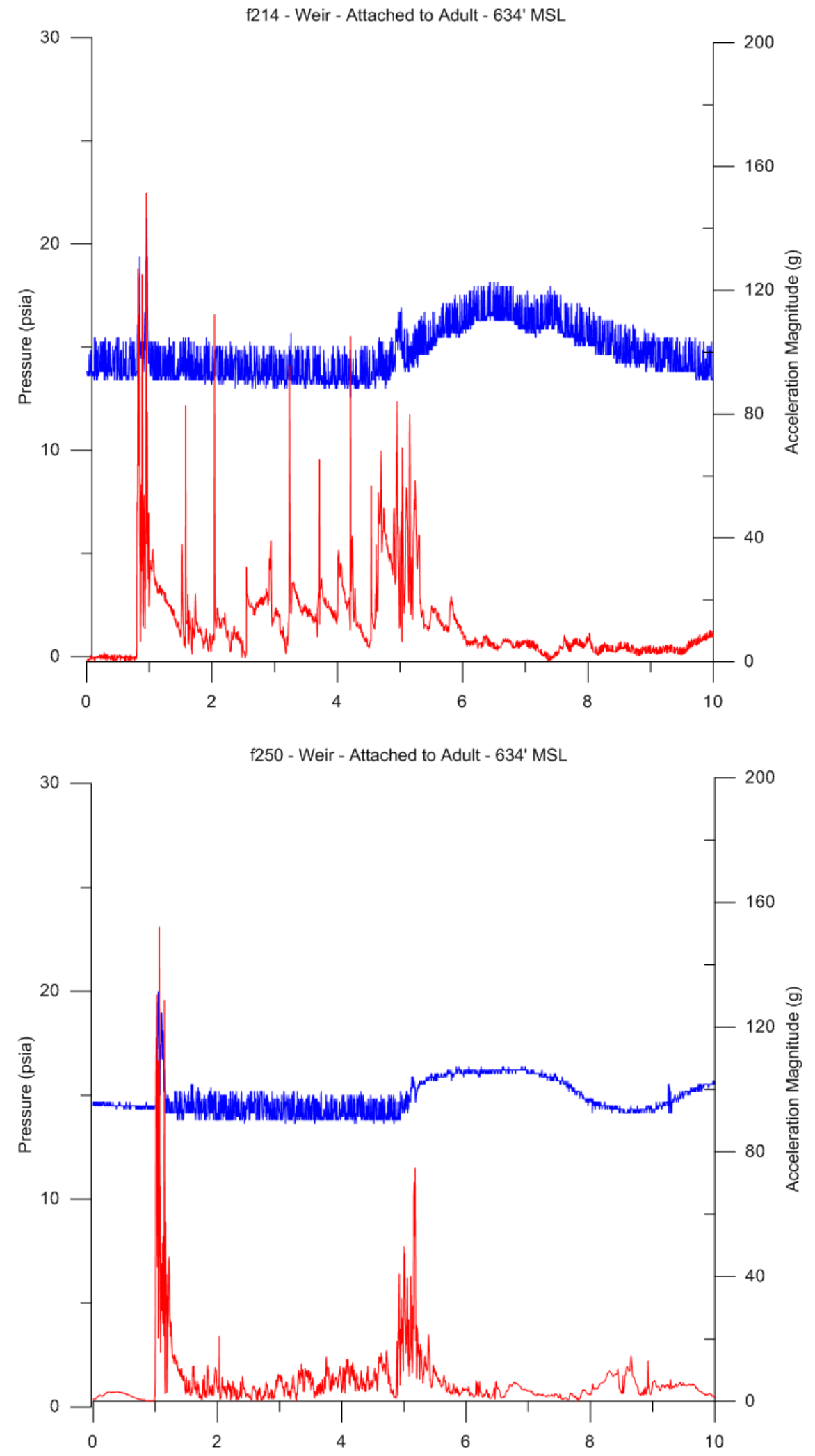


\section{Sensor Fish Turbine Passage - Low-Forebay Elevation (616 ft MSL) 2.8/3.0 MW}



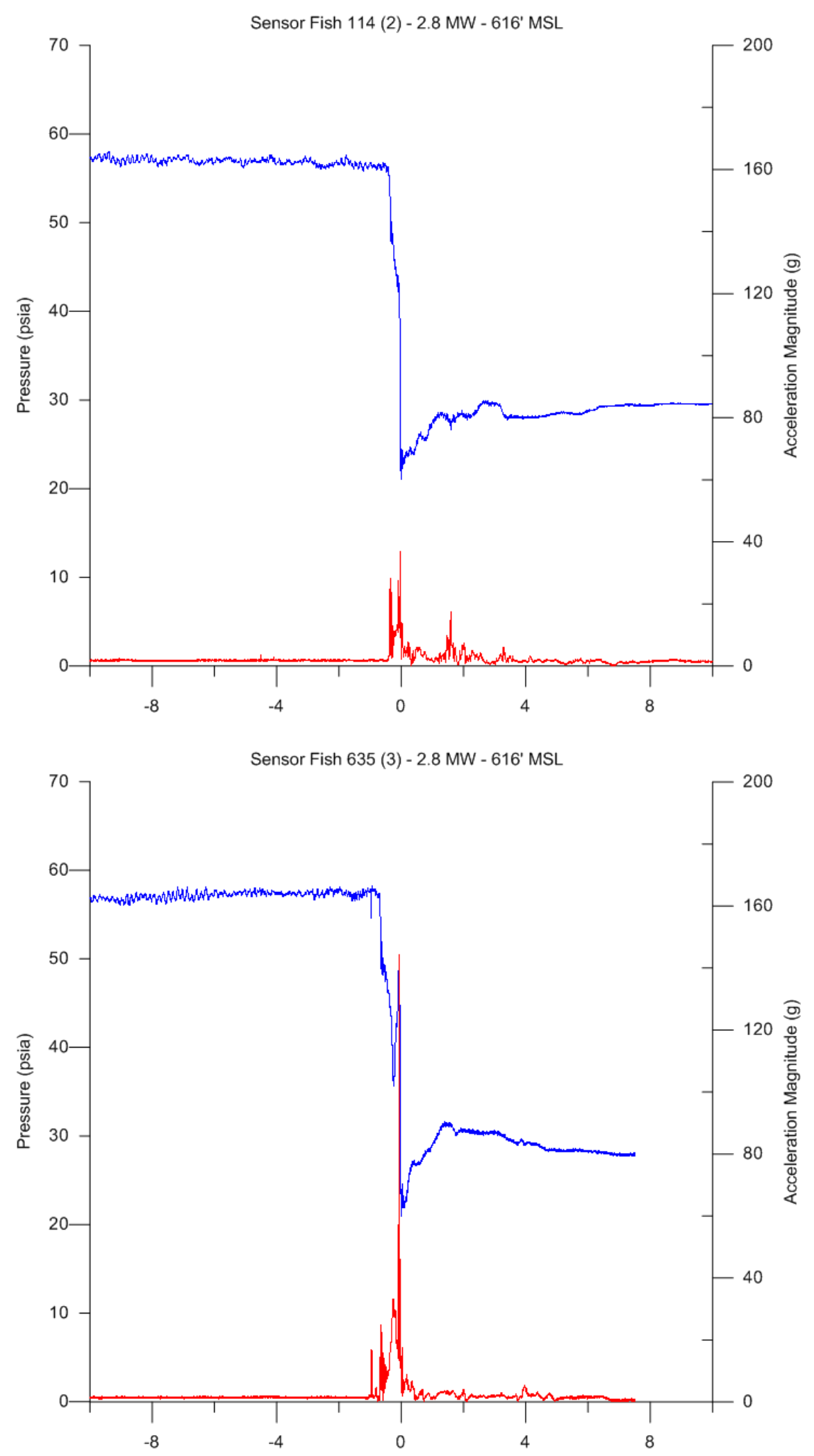

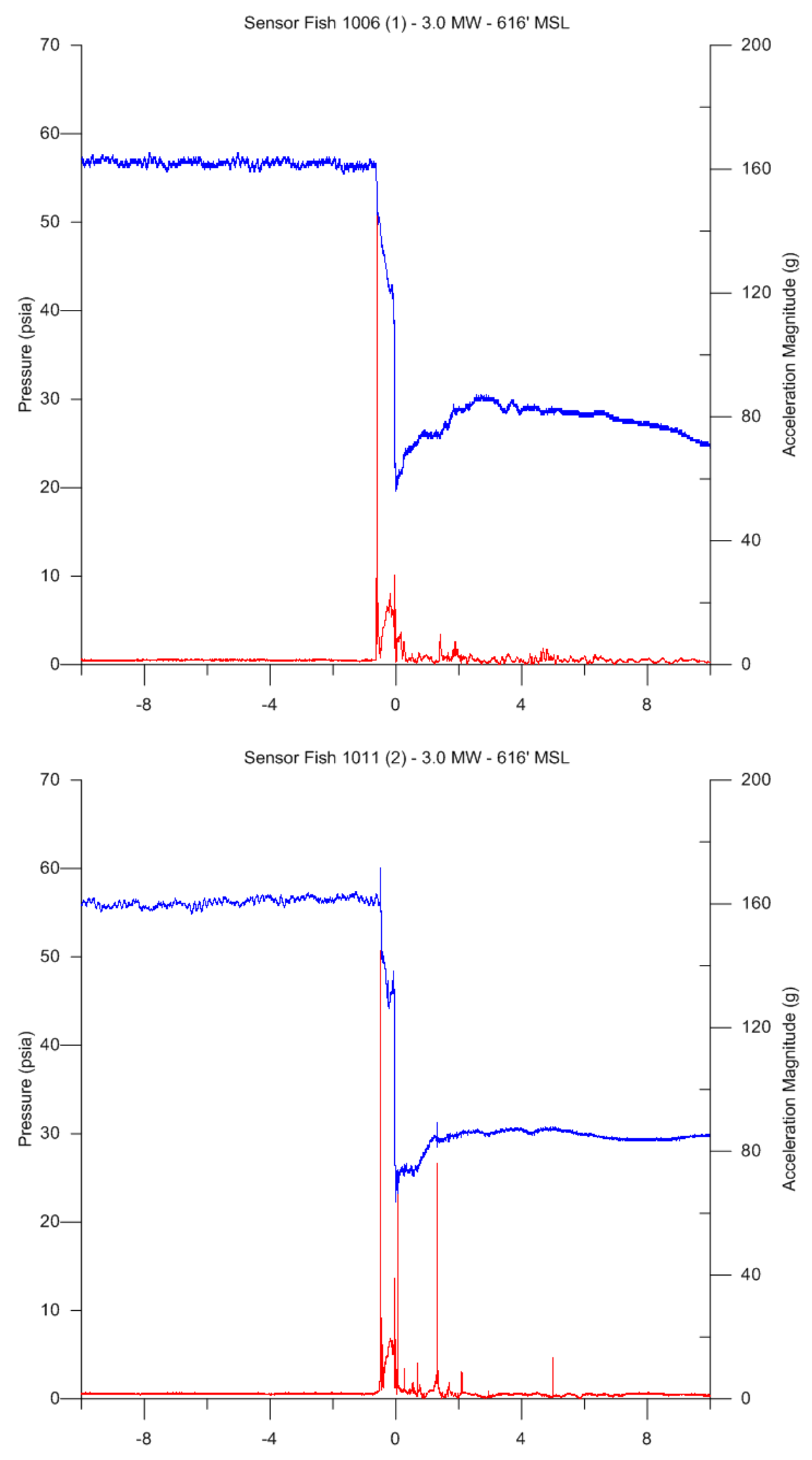


Sensor Fish Turbine Passage Low-Forebay Elevation (616 ft MSL)

4.9/5.0 MW 

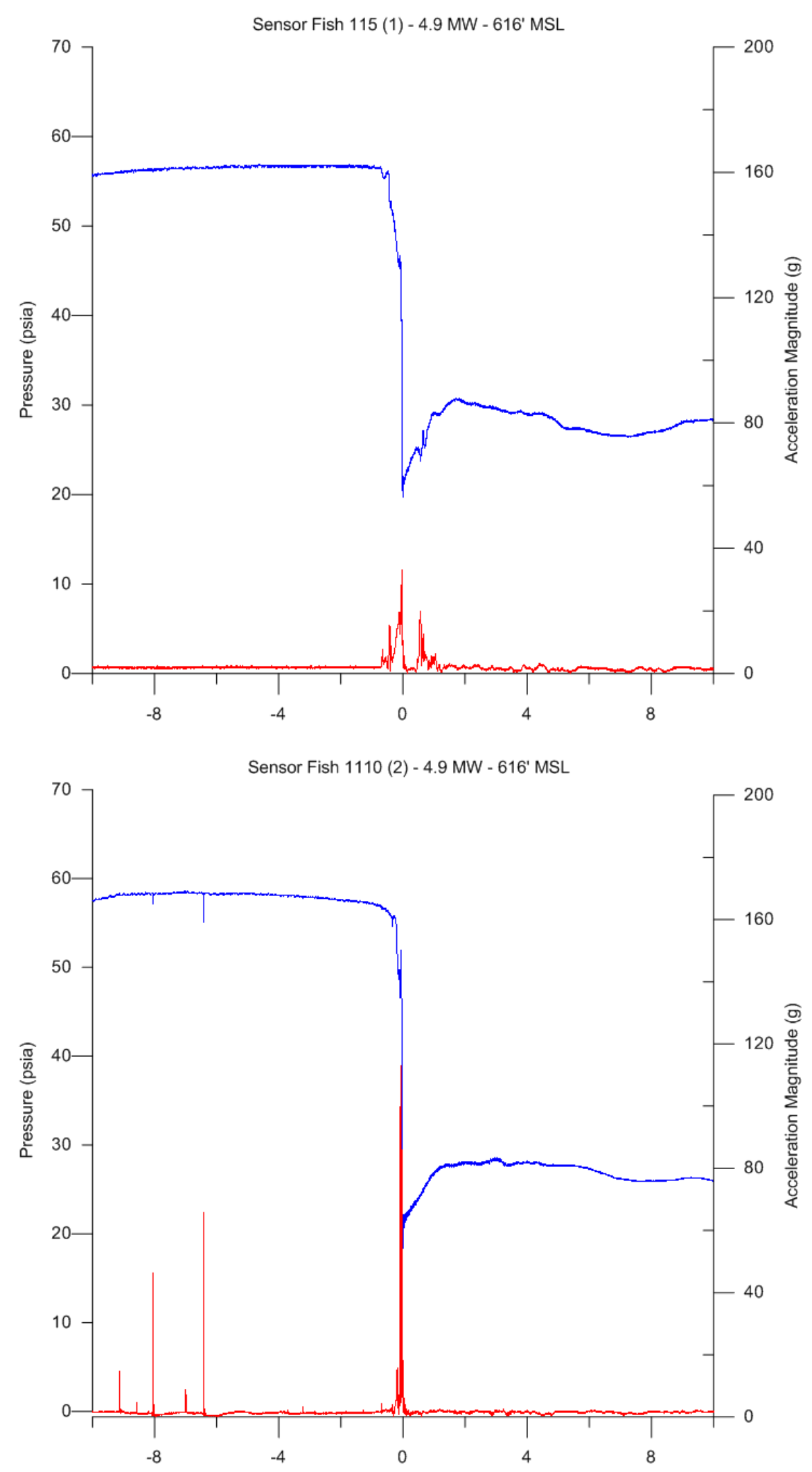

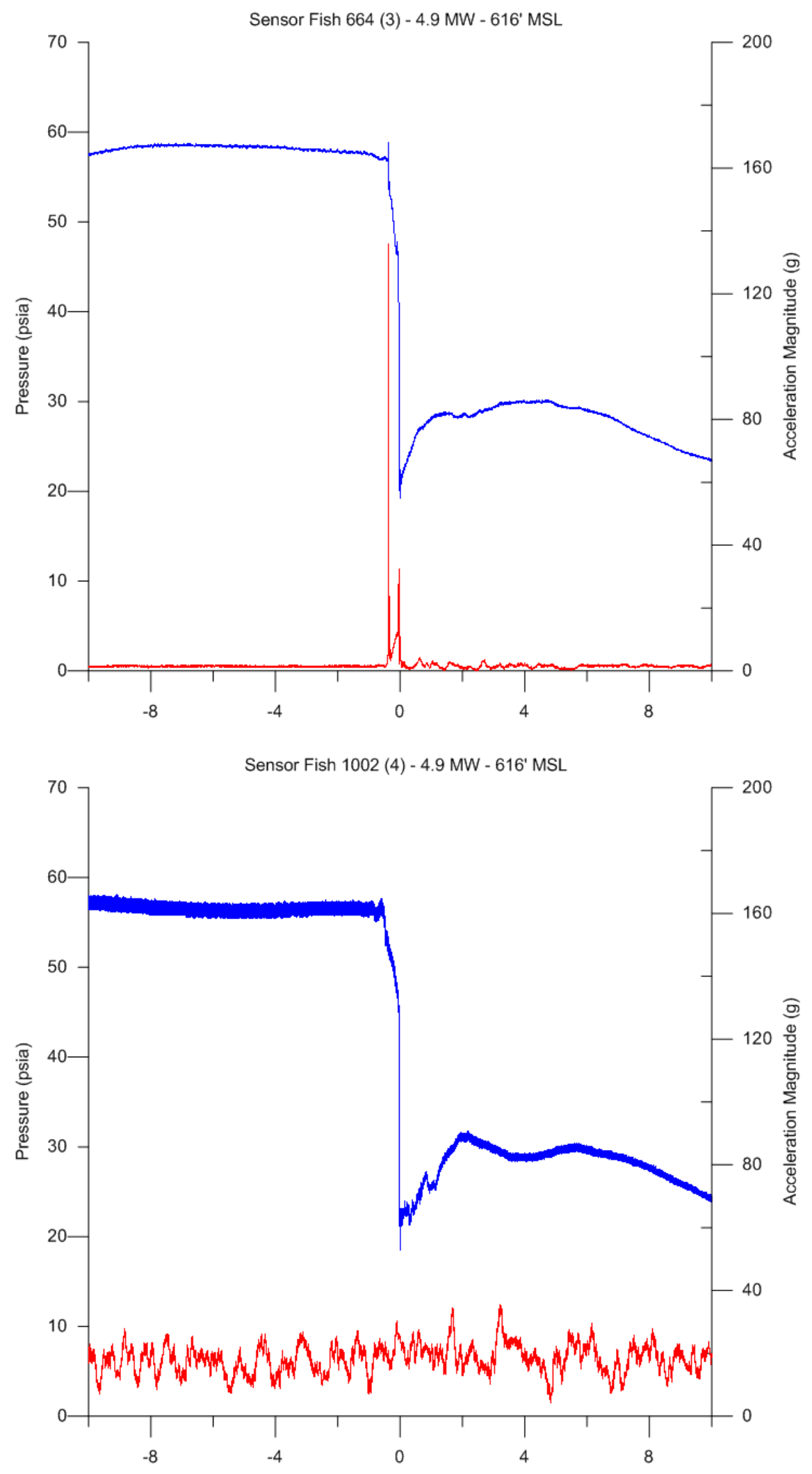

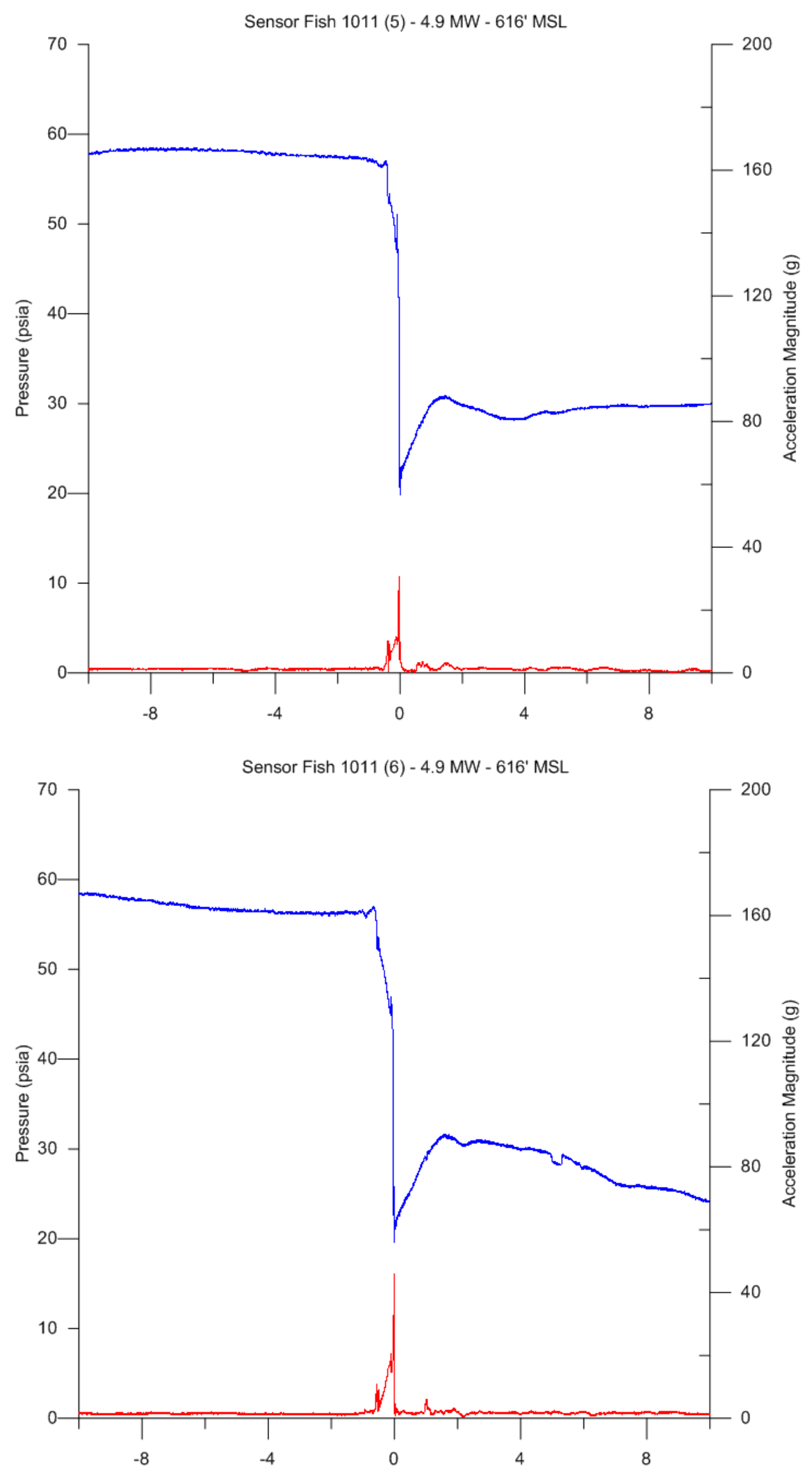

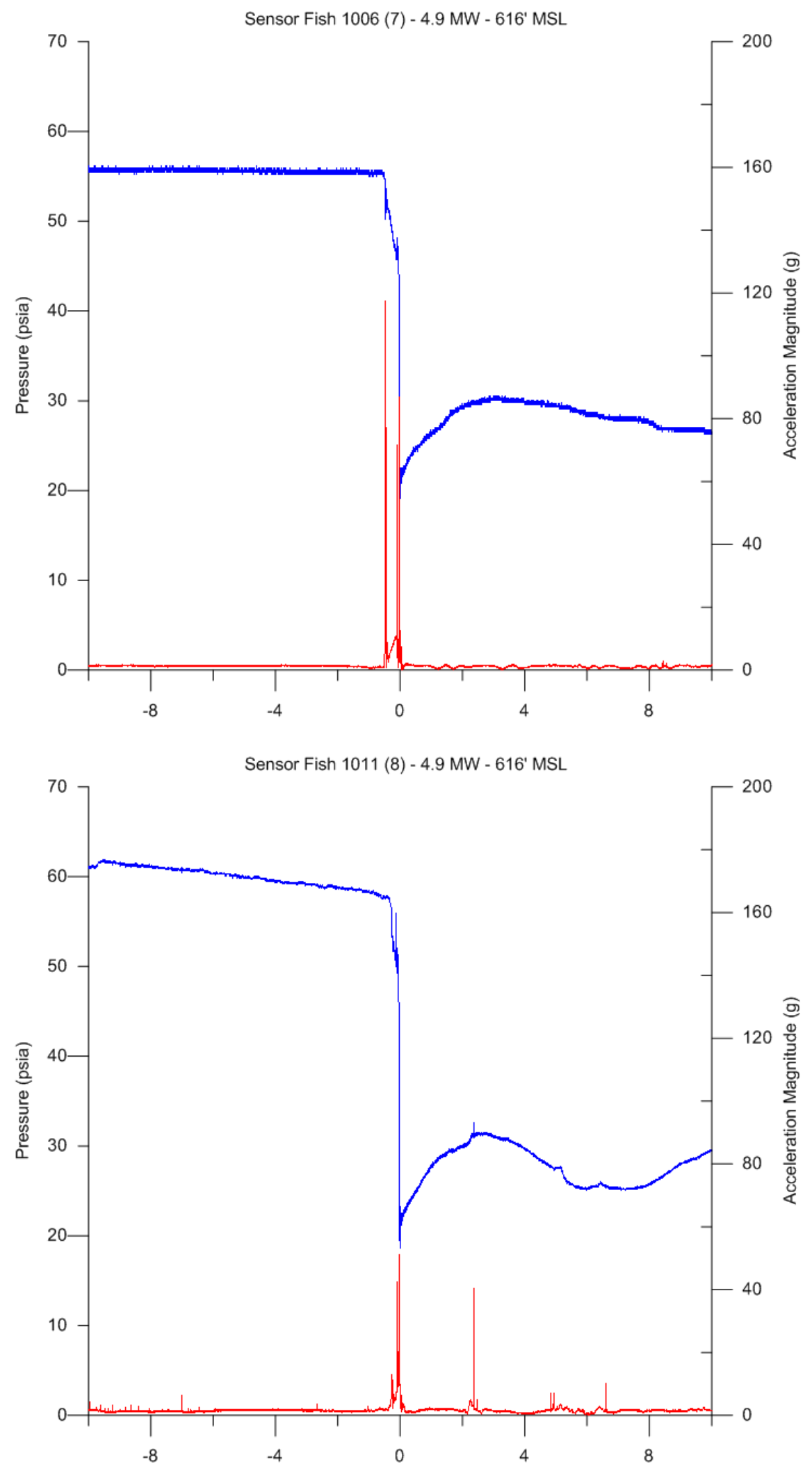


Sensor Fish Turbine Passage Low-Forebay Elevation (616 ft MSL) 6.0 MW 

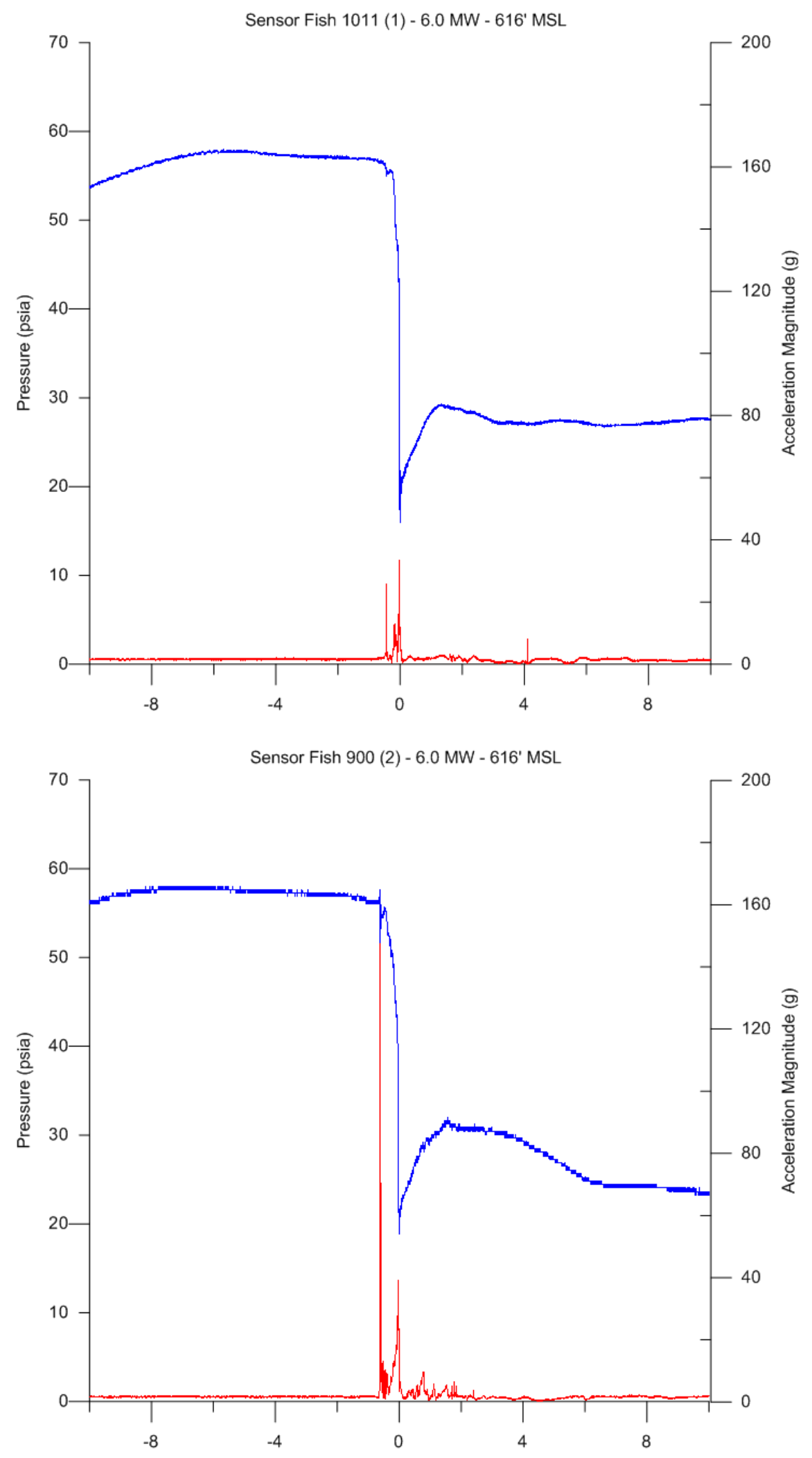




Sensor Fish Turbine Passage Low-Forebay Elevation (616 ft MSL) 7.0 MW 

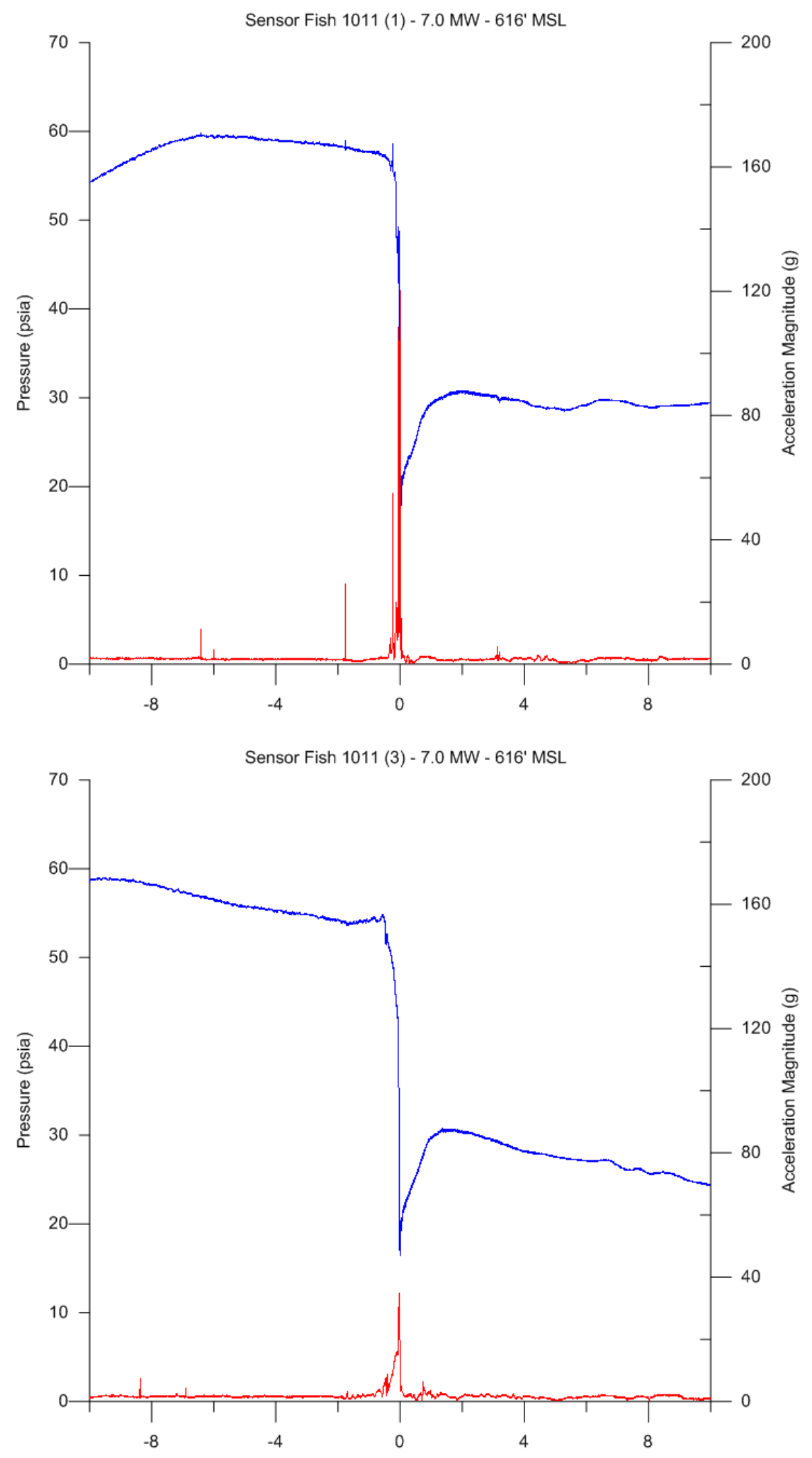

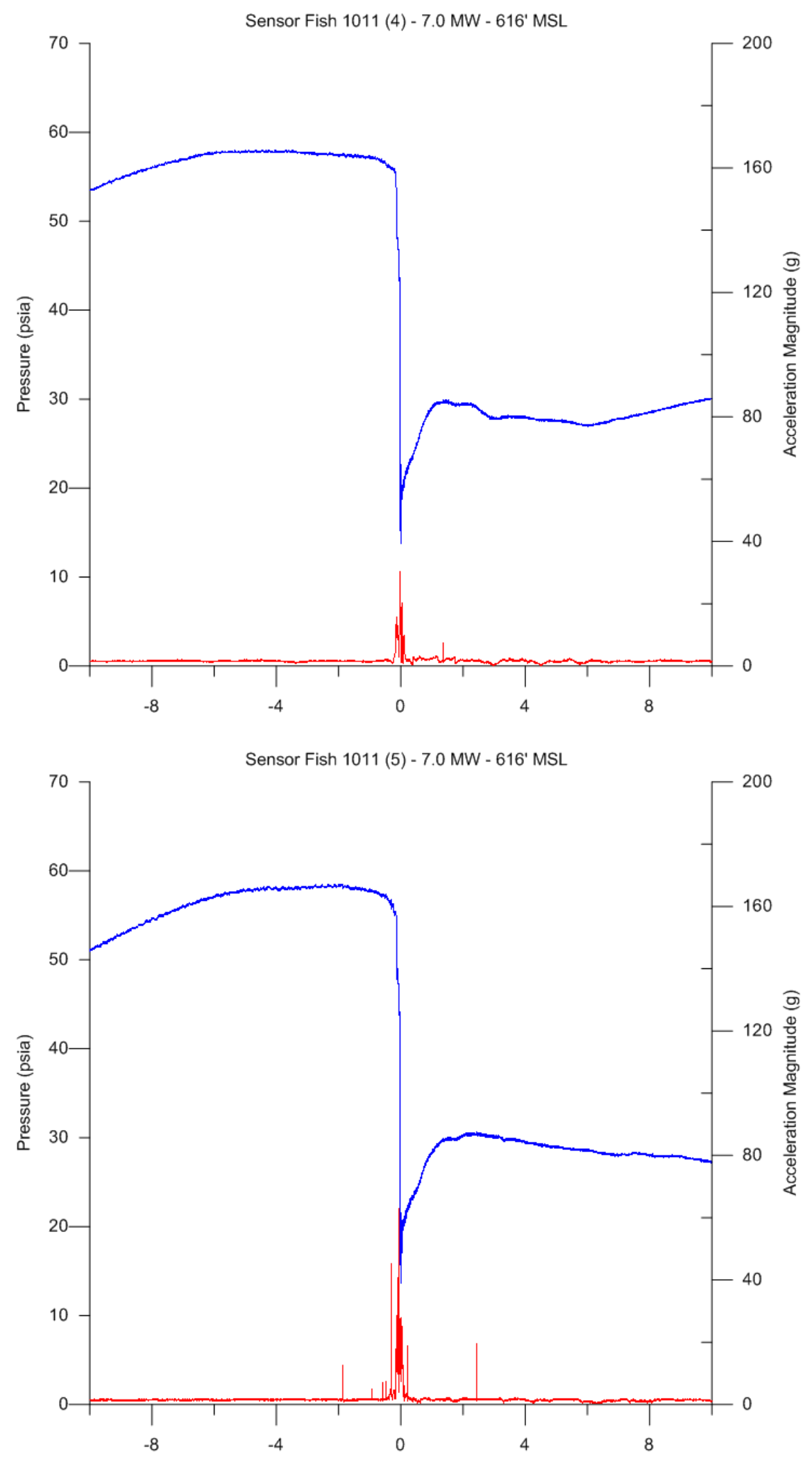


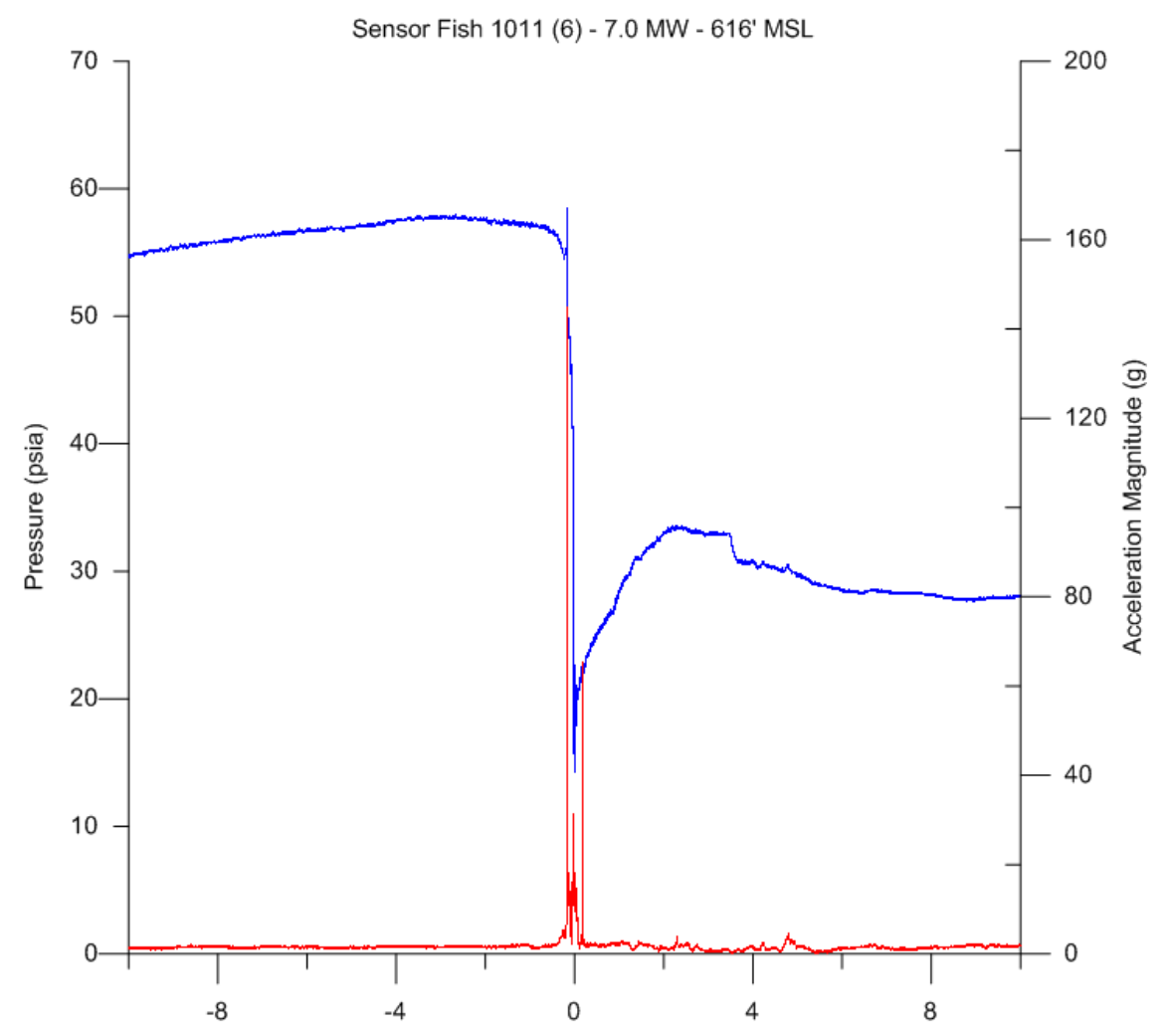


Sensor Fish Turbine Passage High-Forebay Elevation (634 ft MSL)

4.9/5.0 MW 

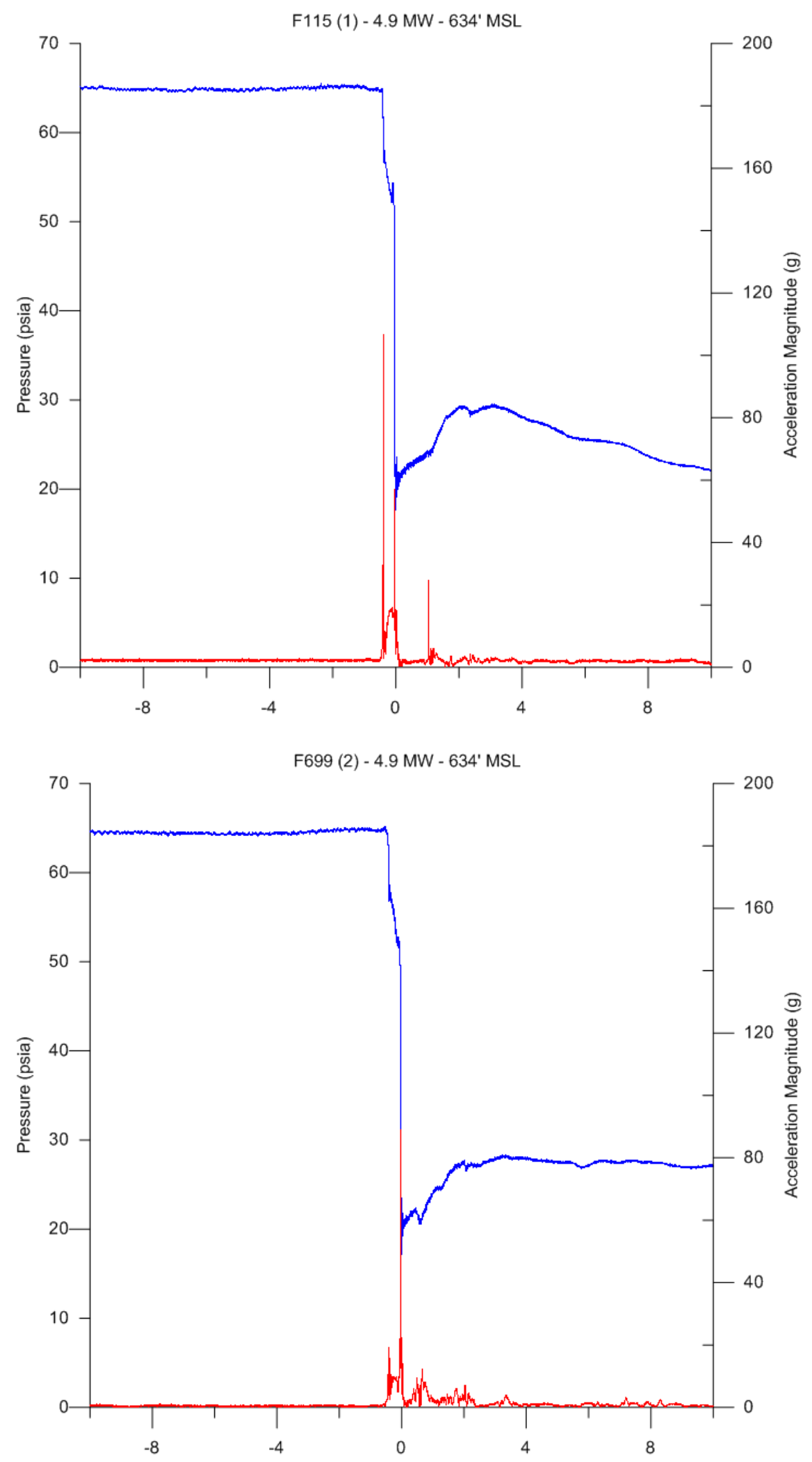
F223 (3) - 4.9 MW - 634' MSL

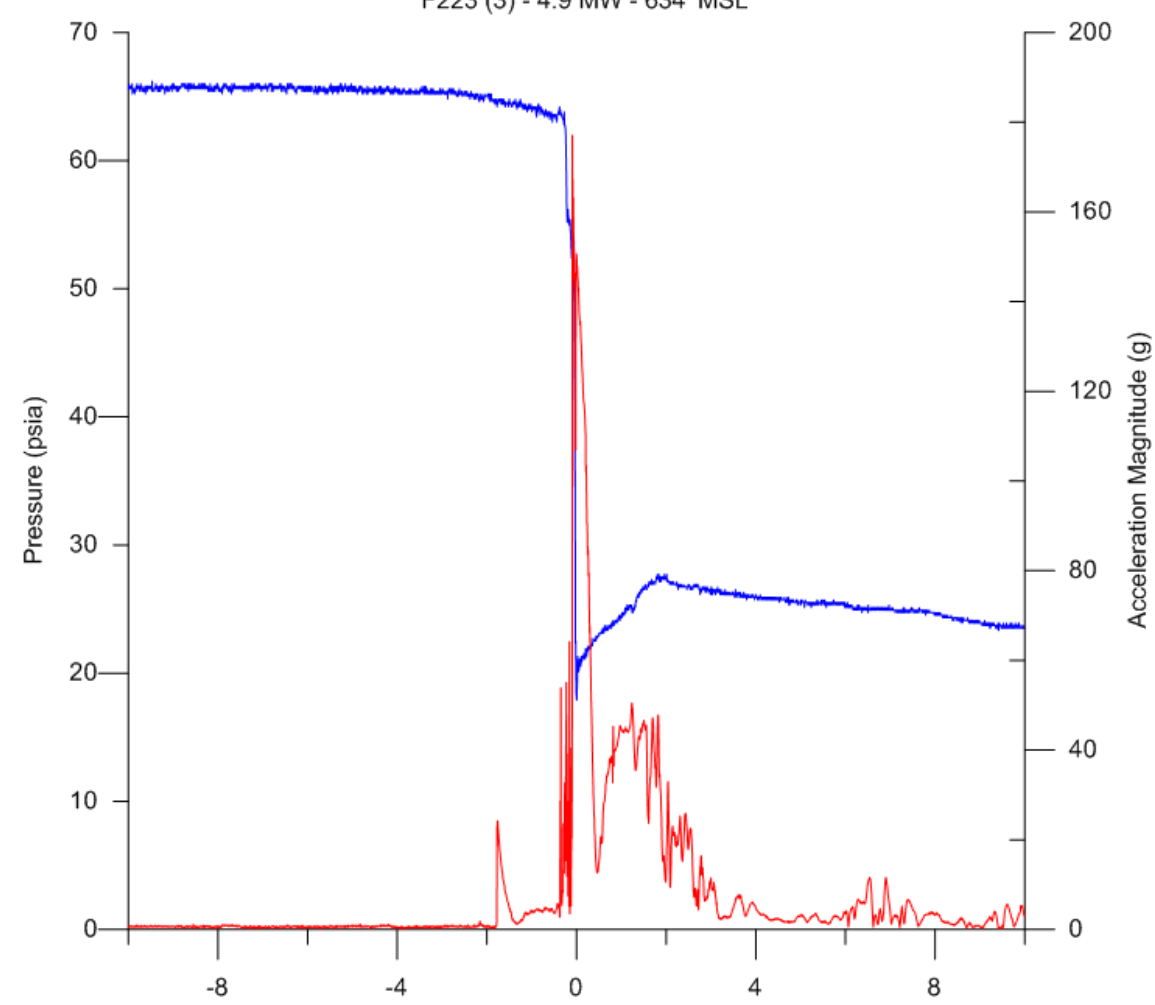

F250 (4) - $4.9 \mathrm{MW}$ - 634' MSL

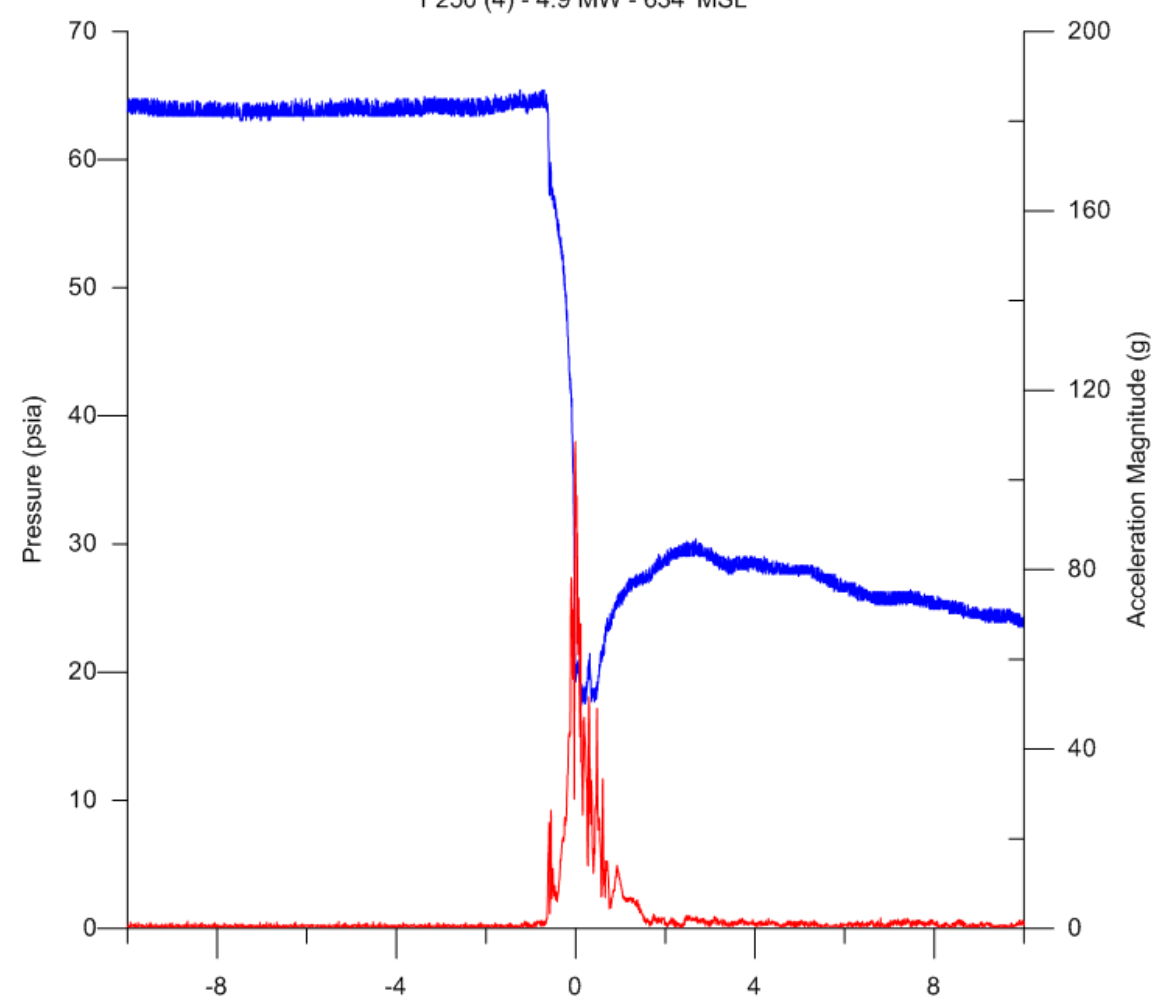


F272 (5) - 4.9 MW - 634' MSL
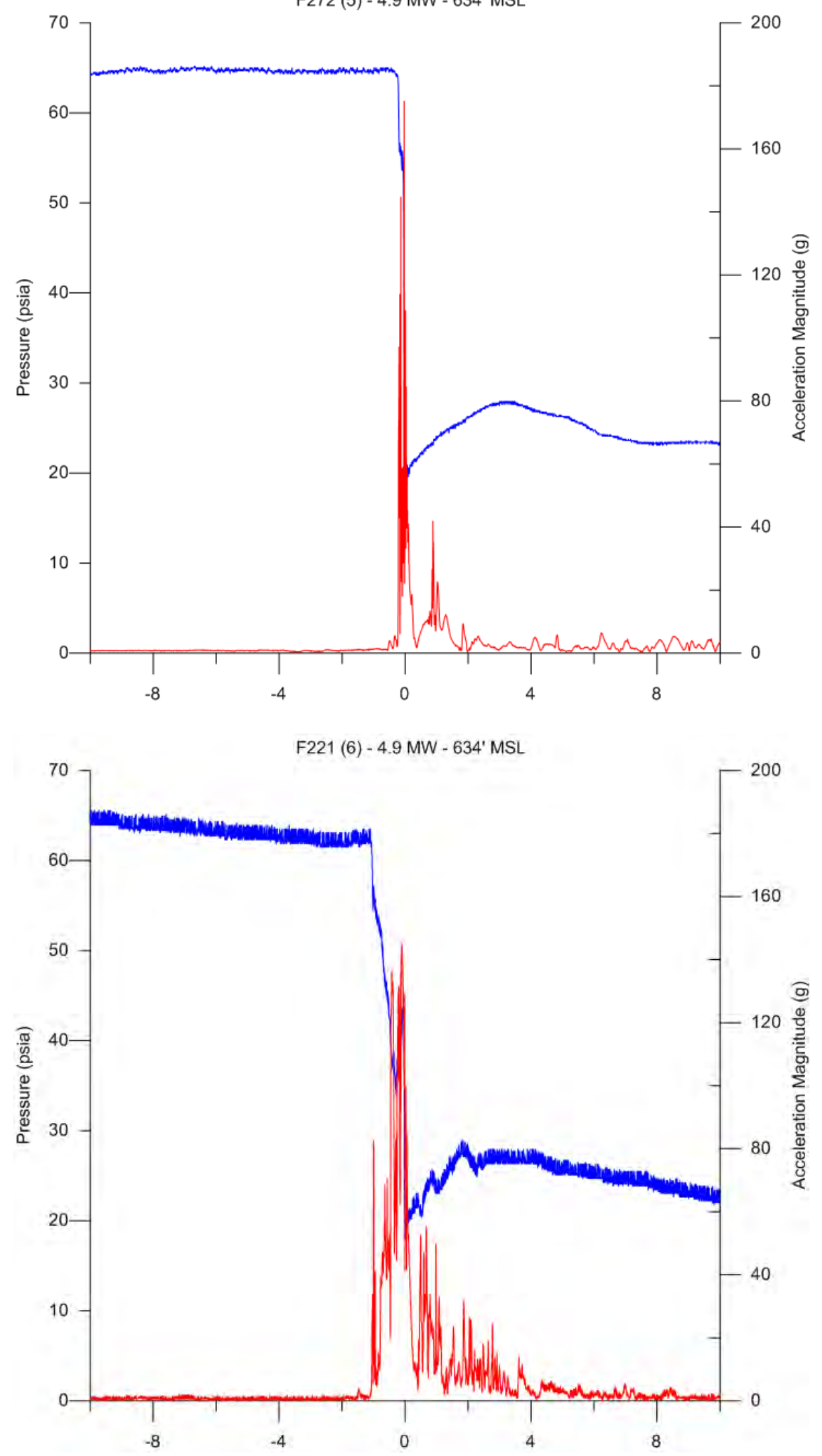
F202 (7) - $4.9 \mathrm{MW}-634^{\prime} \mathrm{MSL}$



F239 (8) - 4.9 MW - 634' MSL

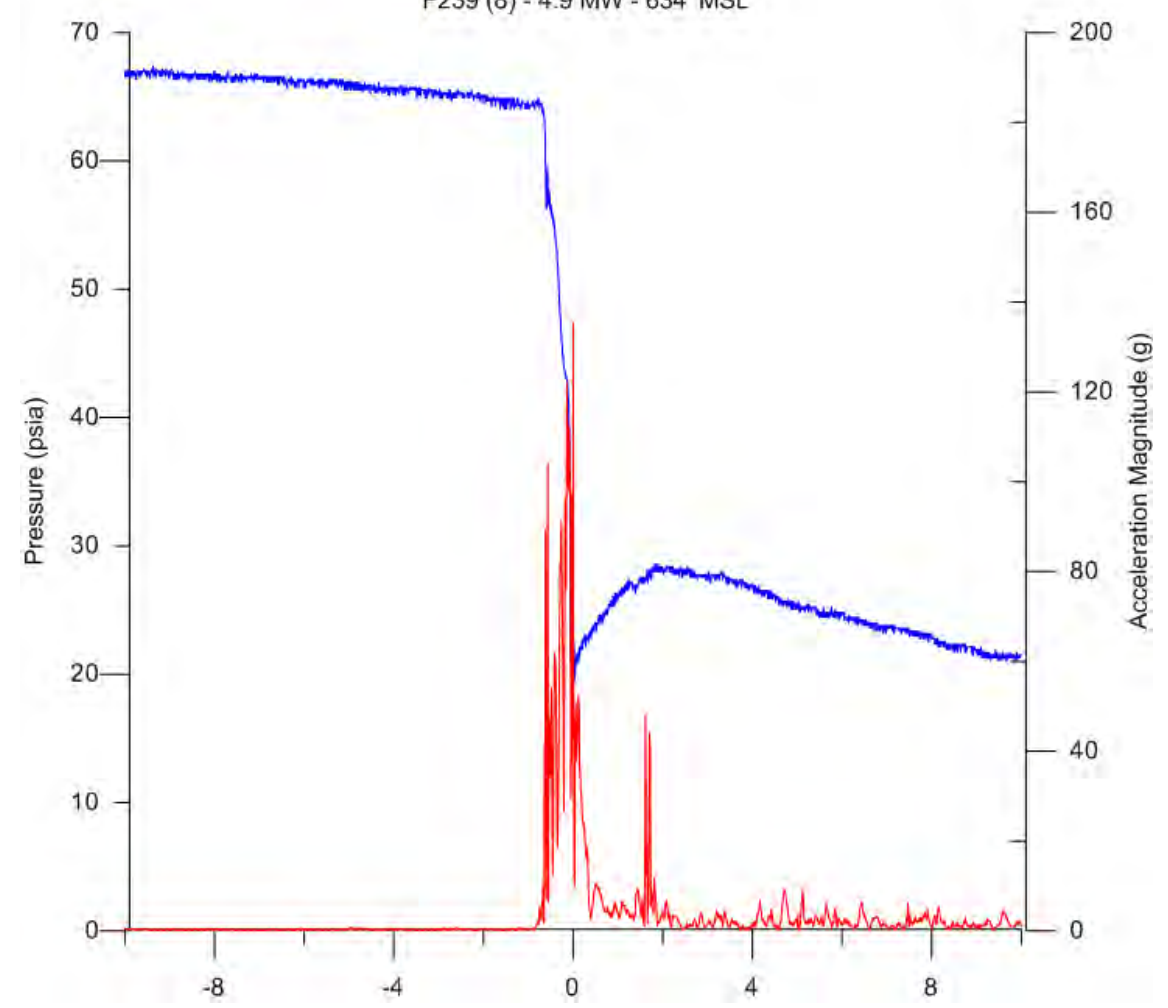


Sensor Fish Turbine Passage High-Forebay Elevation (634 ft MSL) 6.5 MW 



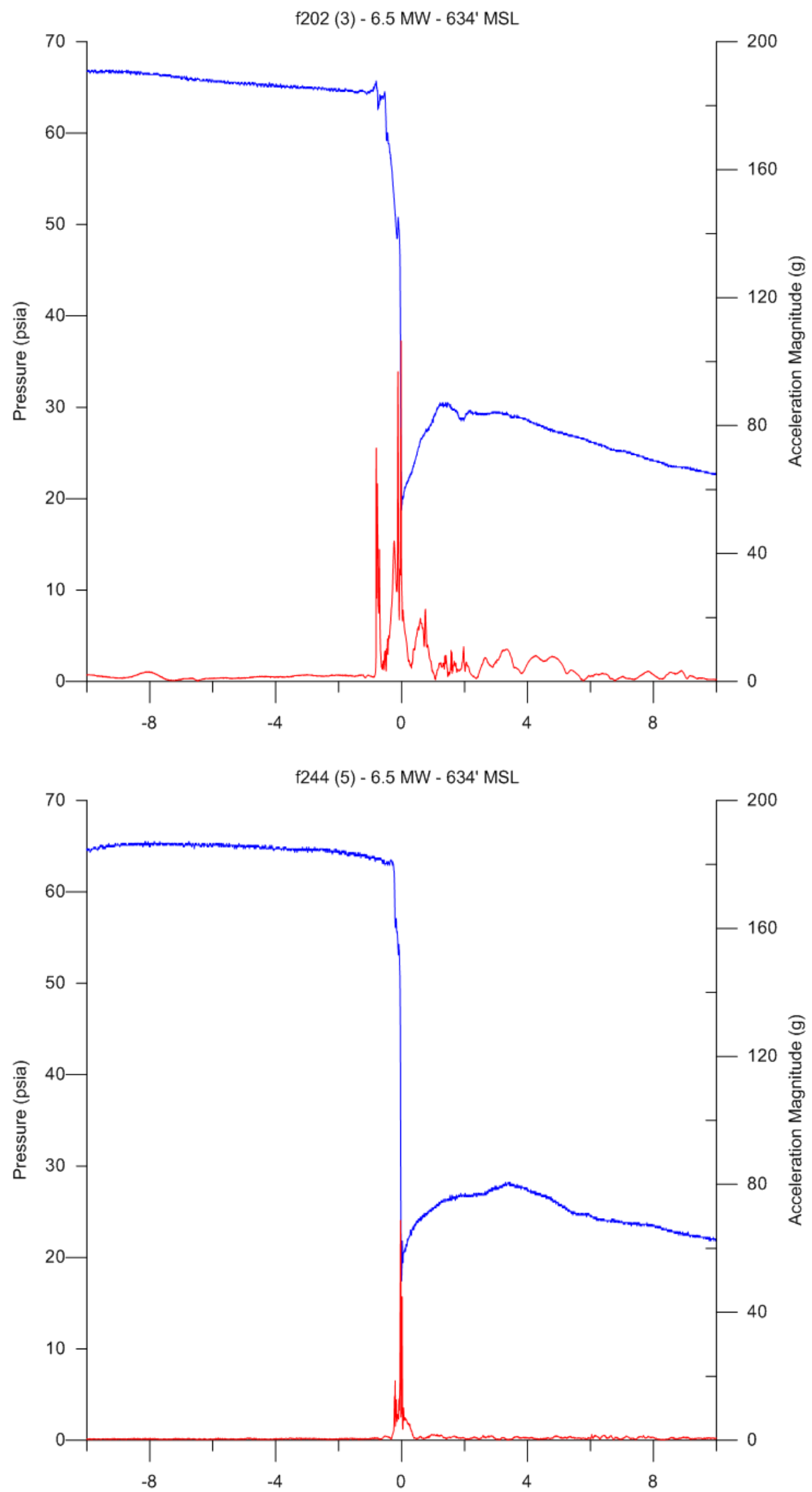

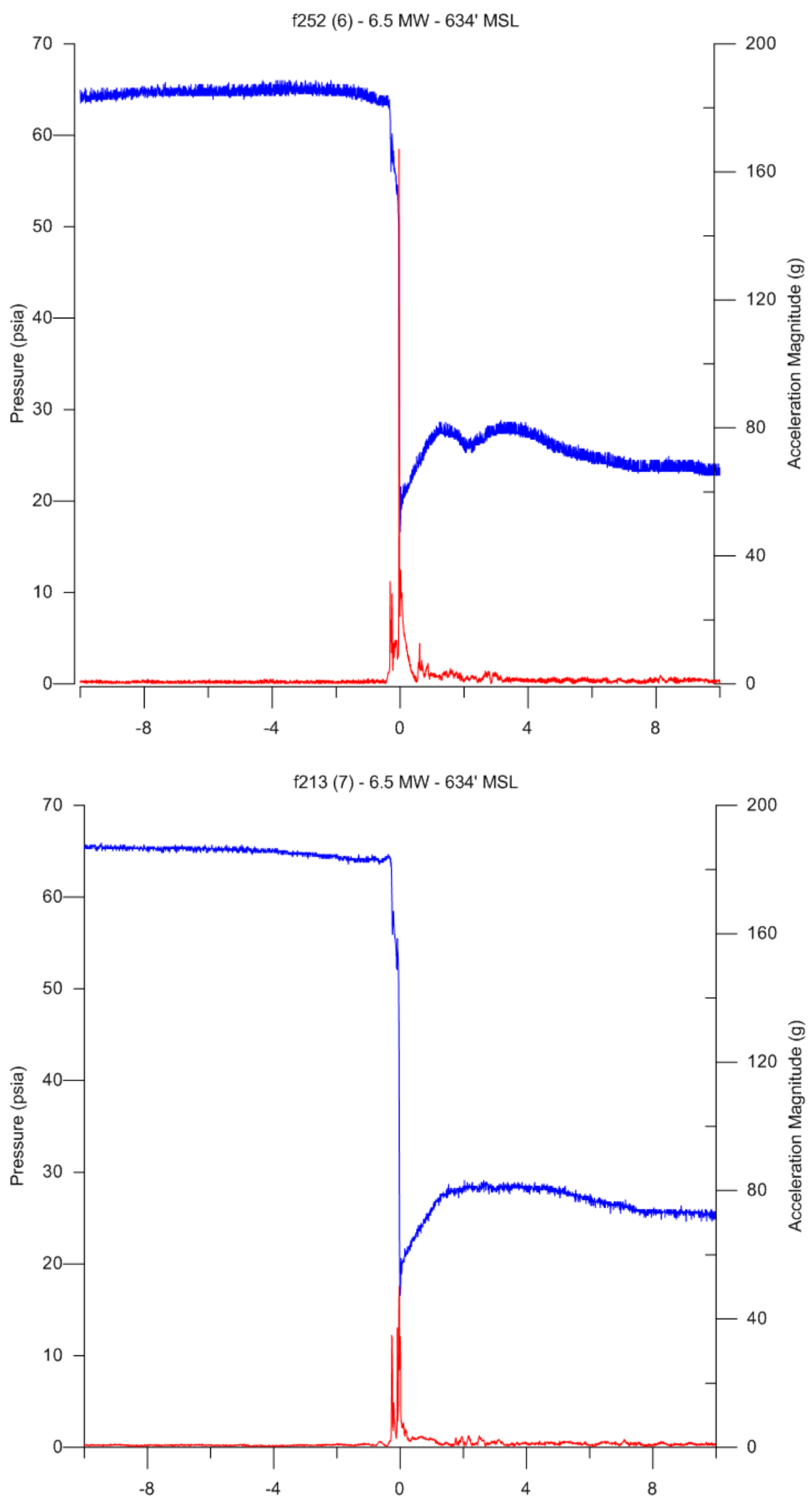


Sensor Fish Turbine Passage High-Forebay Elevation (634 ft MSL) $9.0 \mathrm{MW}$ 



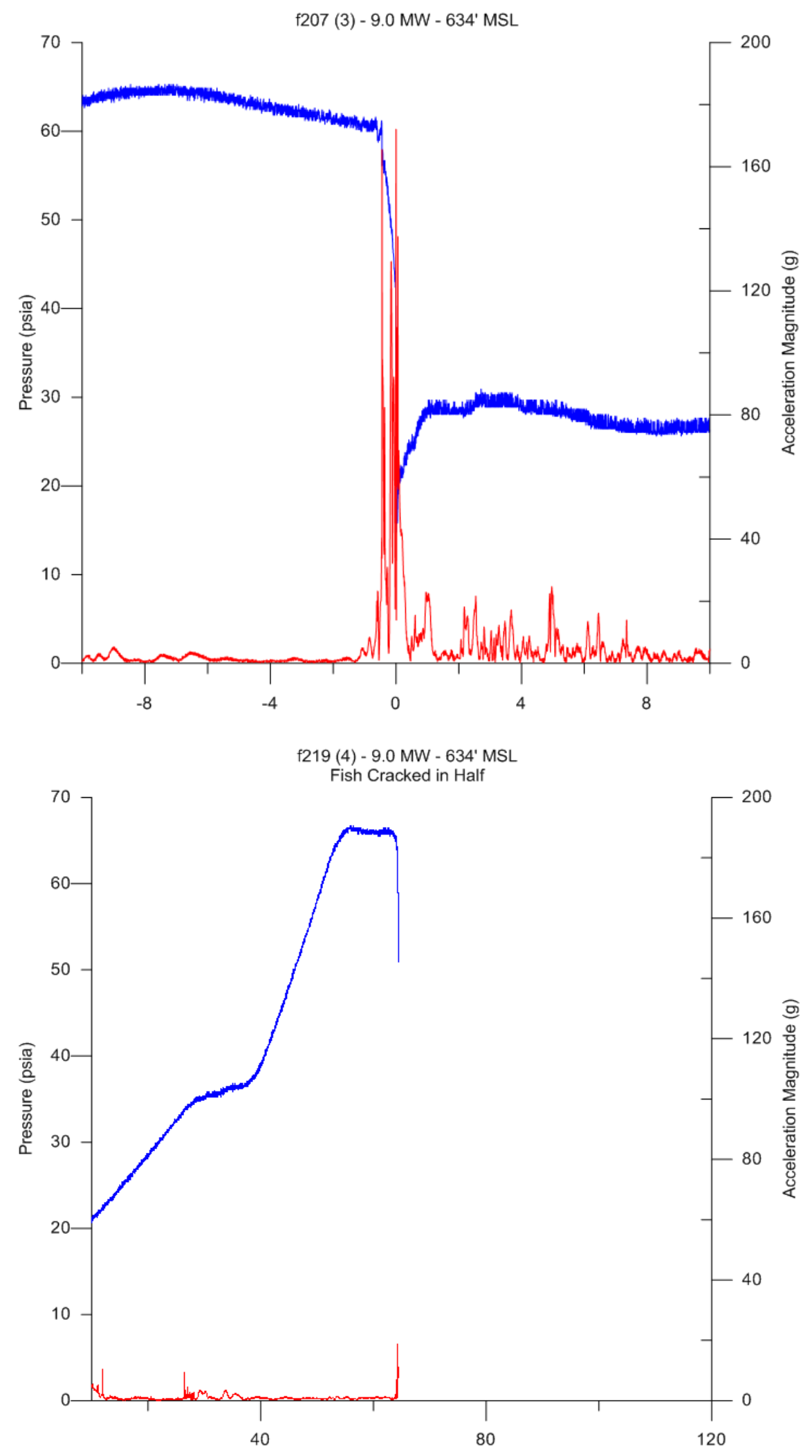

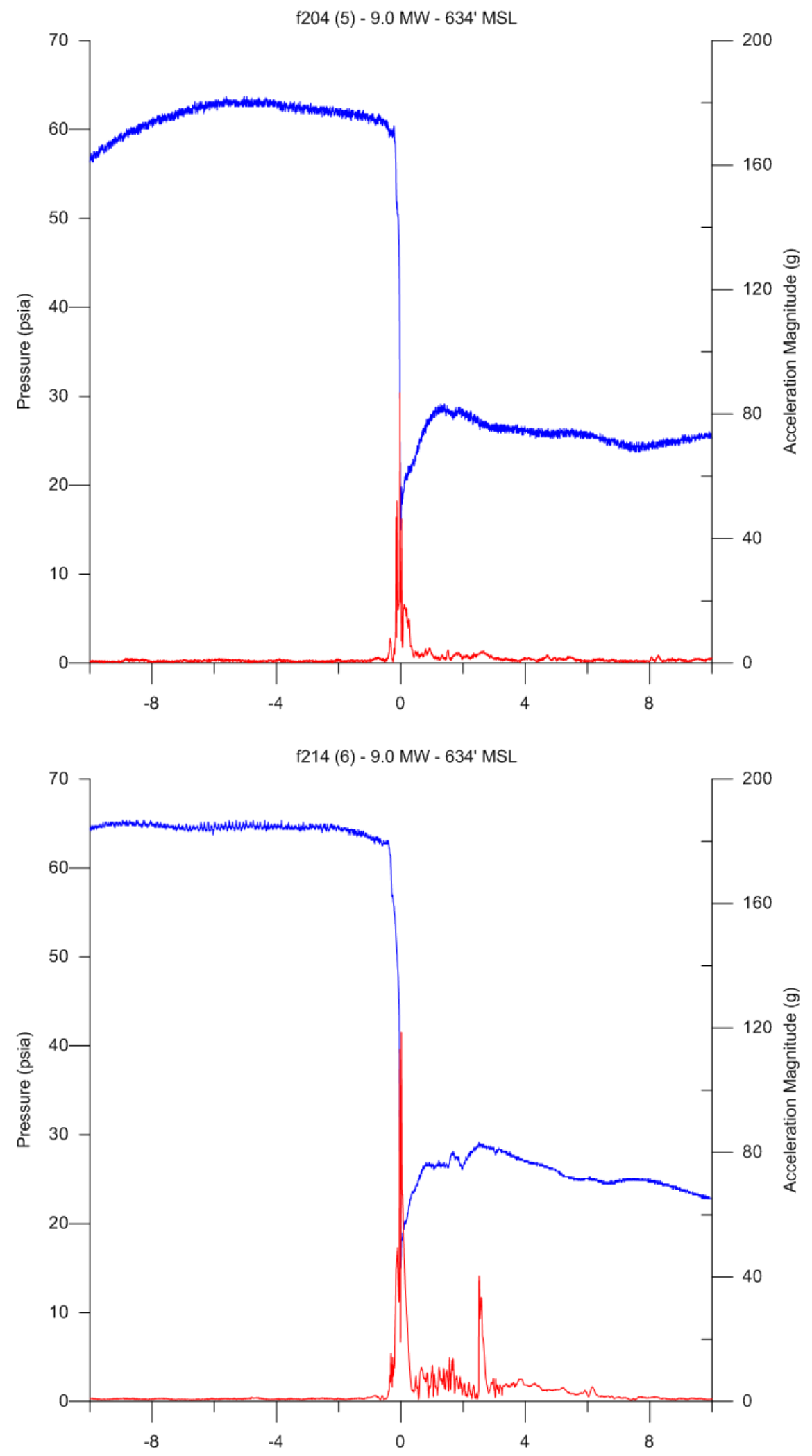

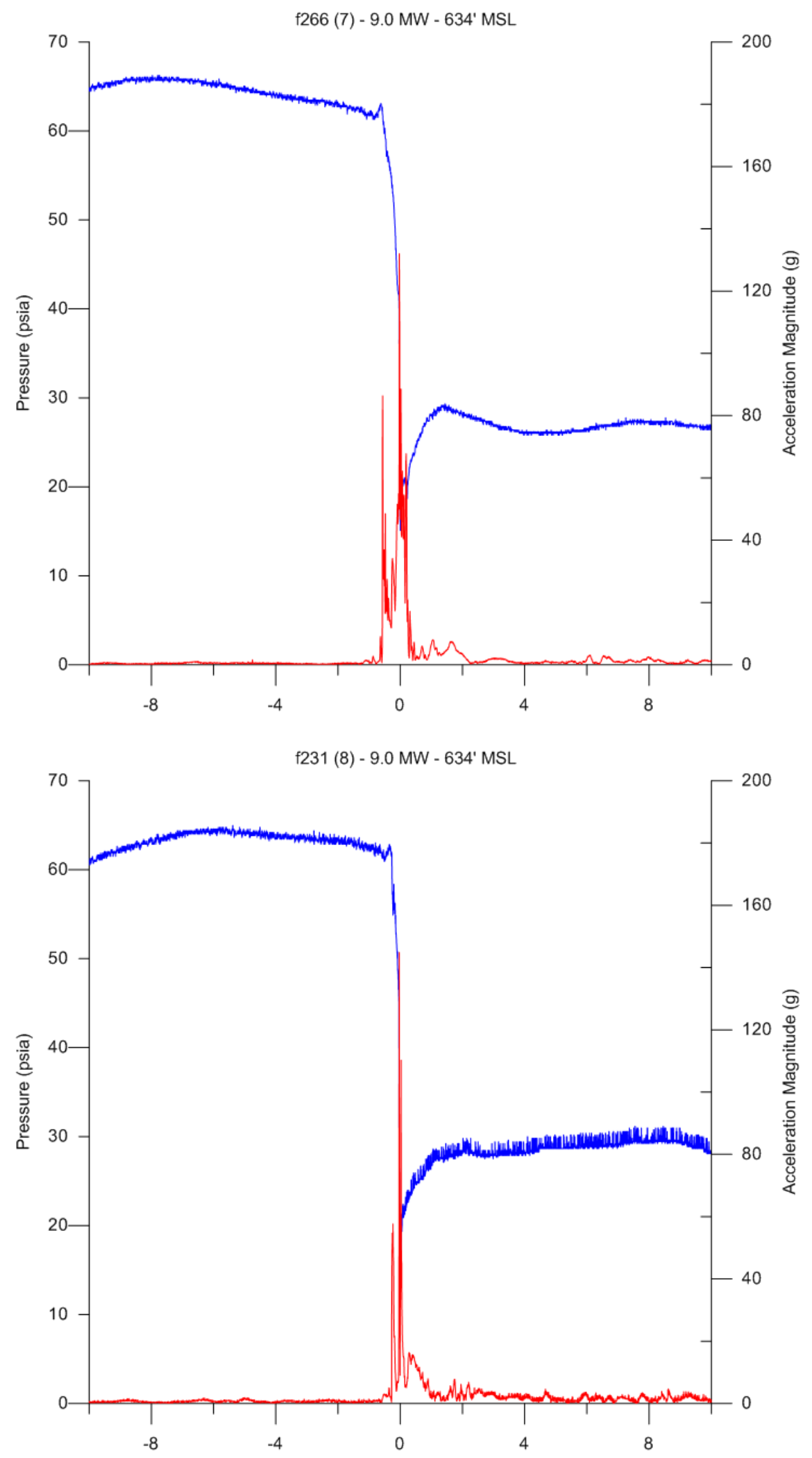


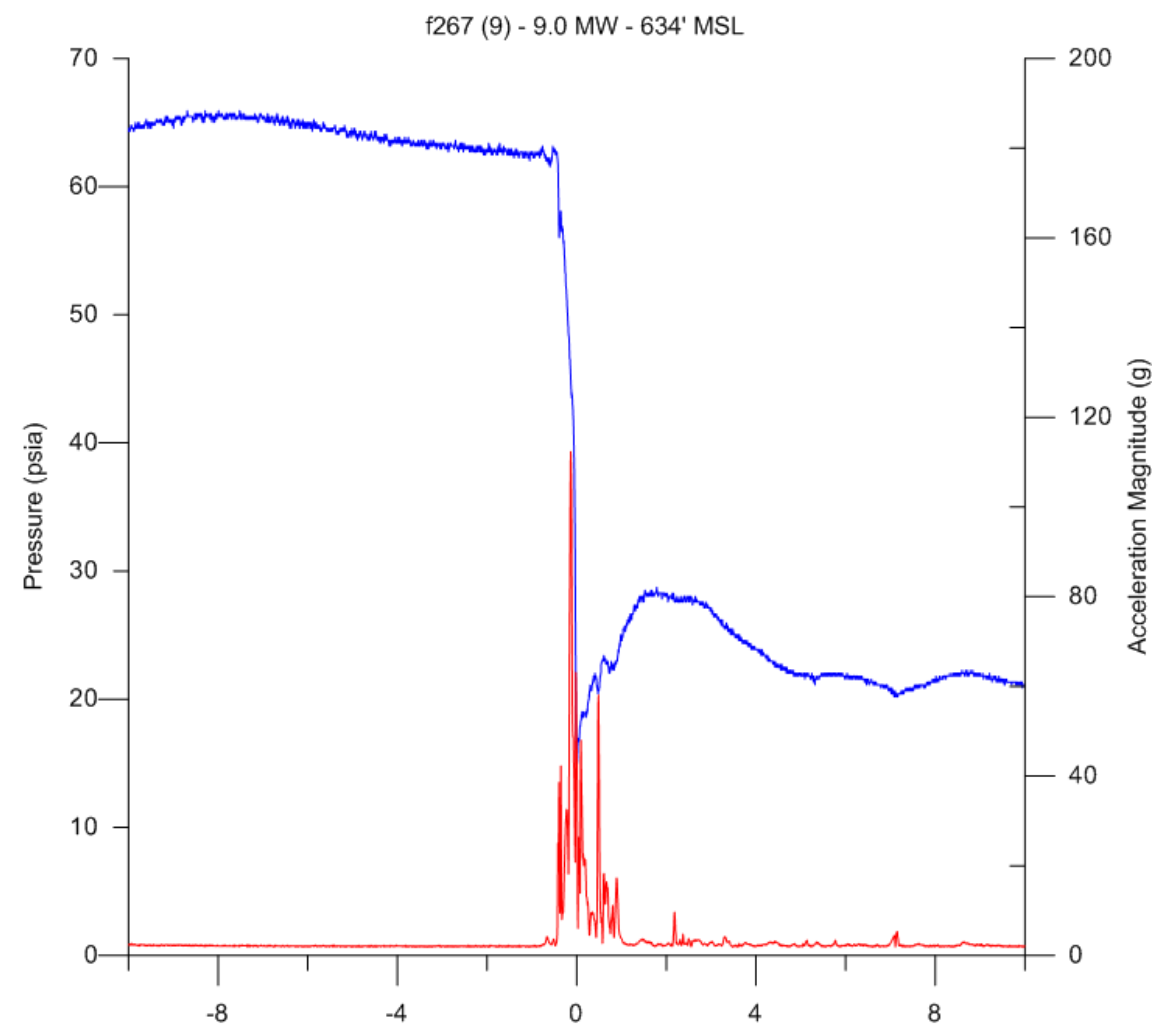


Appendix D

\section{Pressure and Angular Rate-of-Change Time Histories of Each Sensor Fish Release}


Sensor Fish Weir Passage Low-Forebay Elevation (616 ft MSL) Juvenile Pipe 

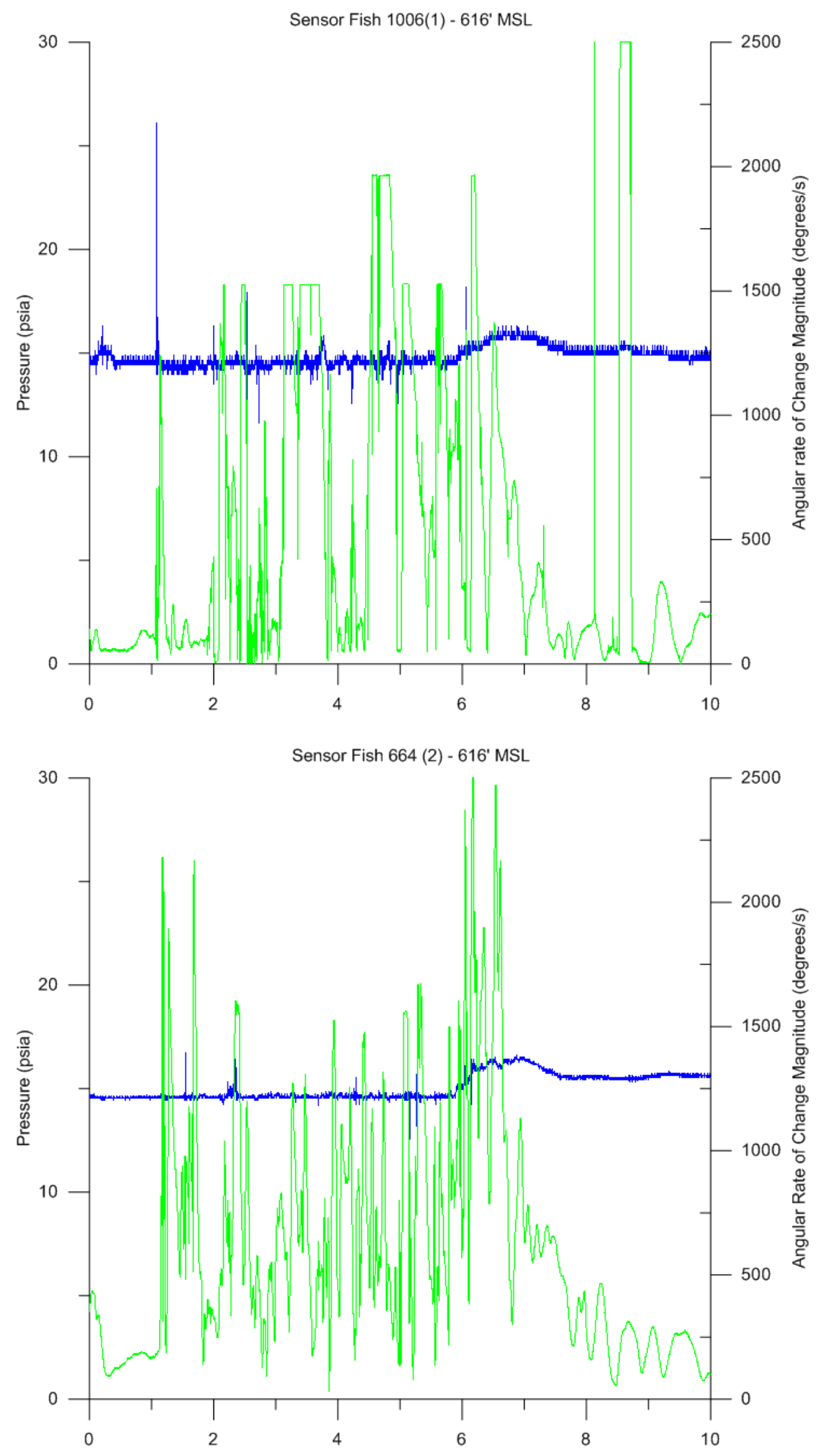

D. 3 

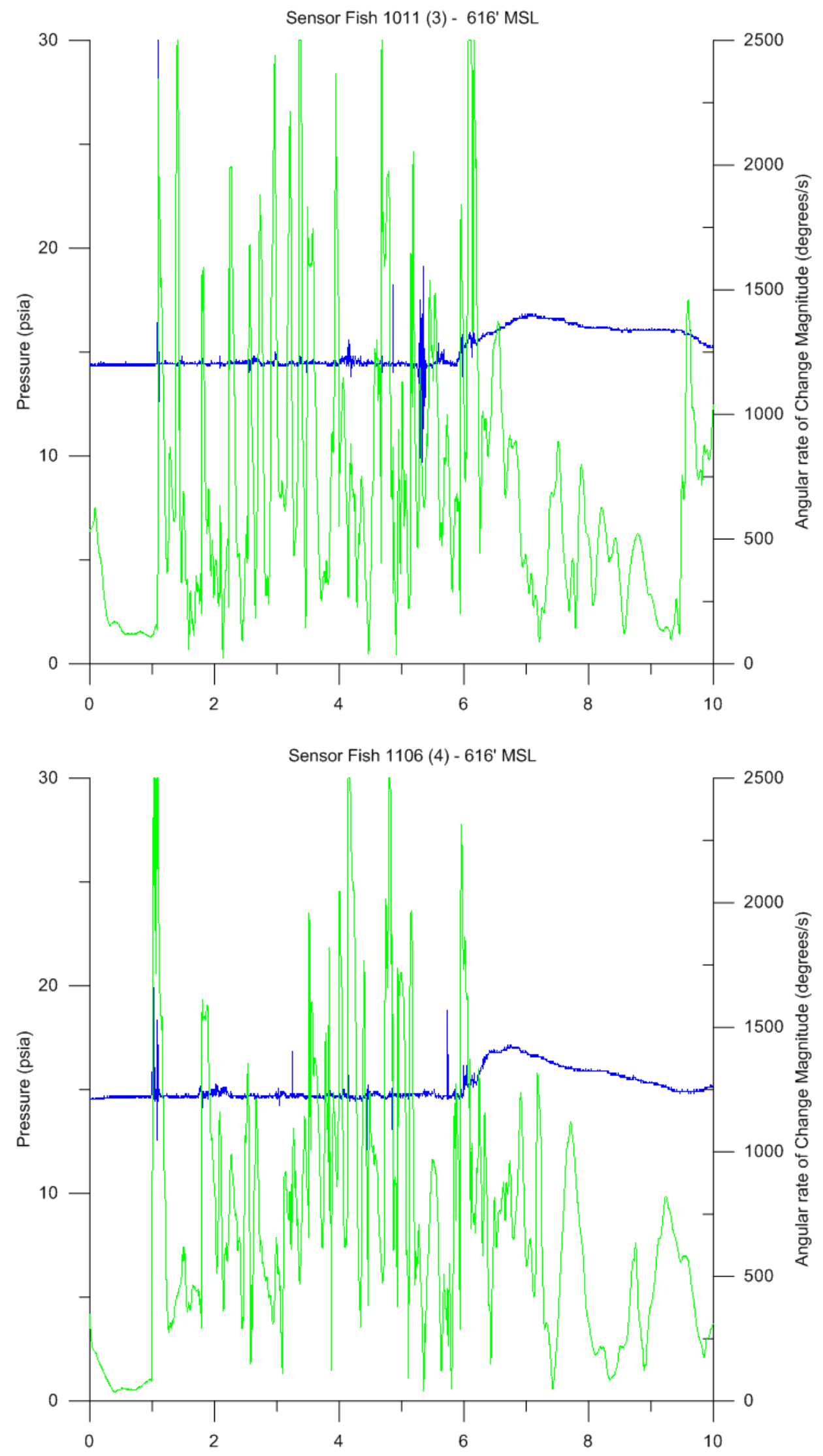

D. 4 

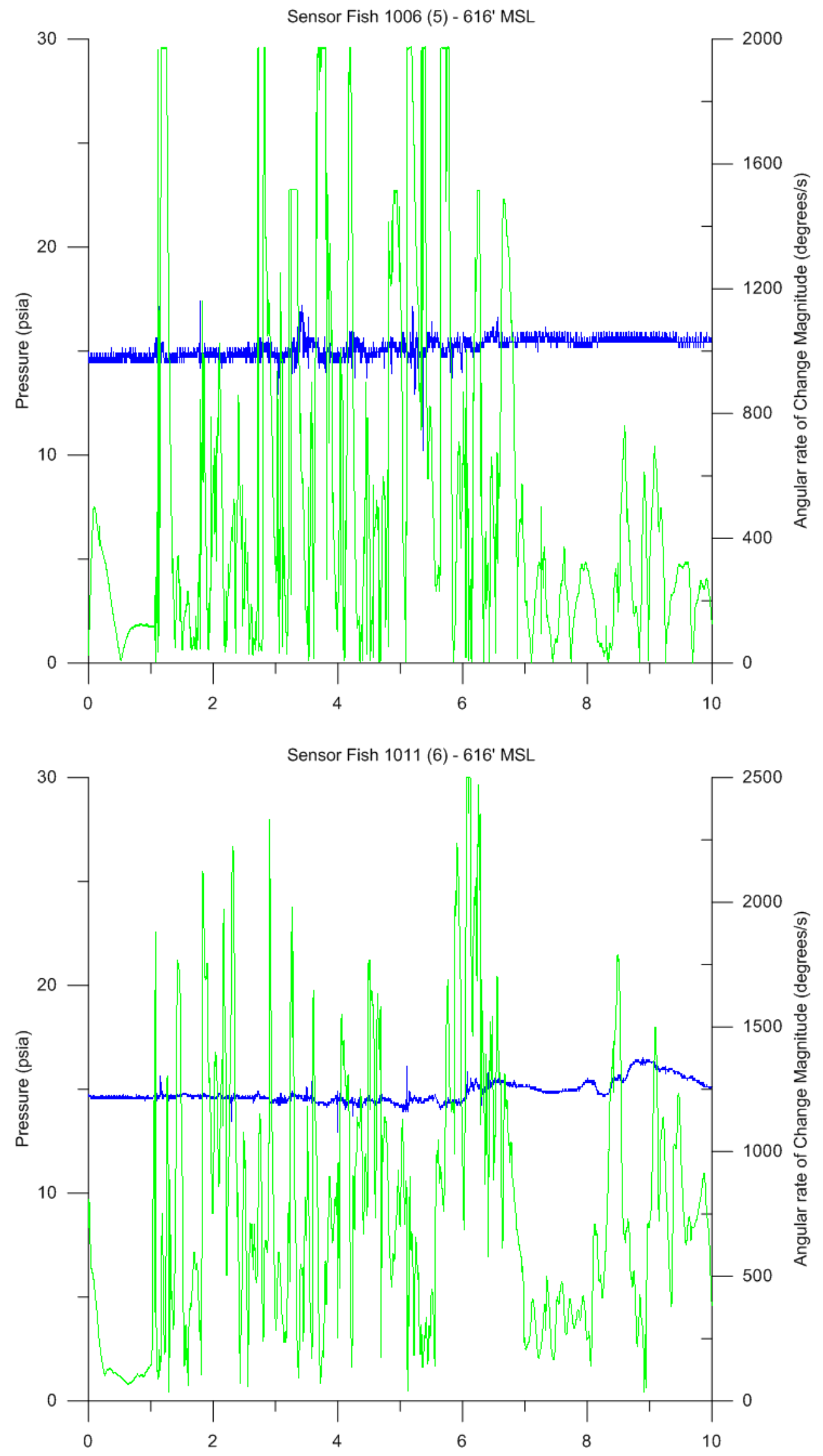

D. 5 

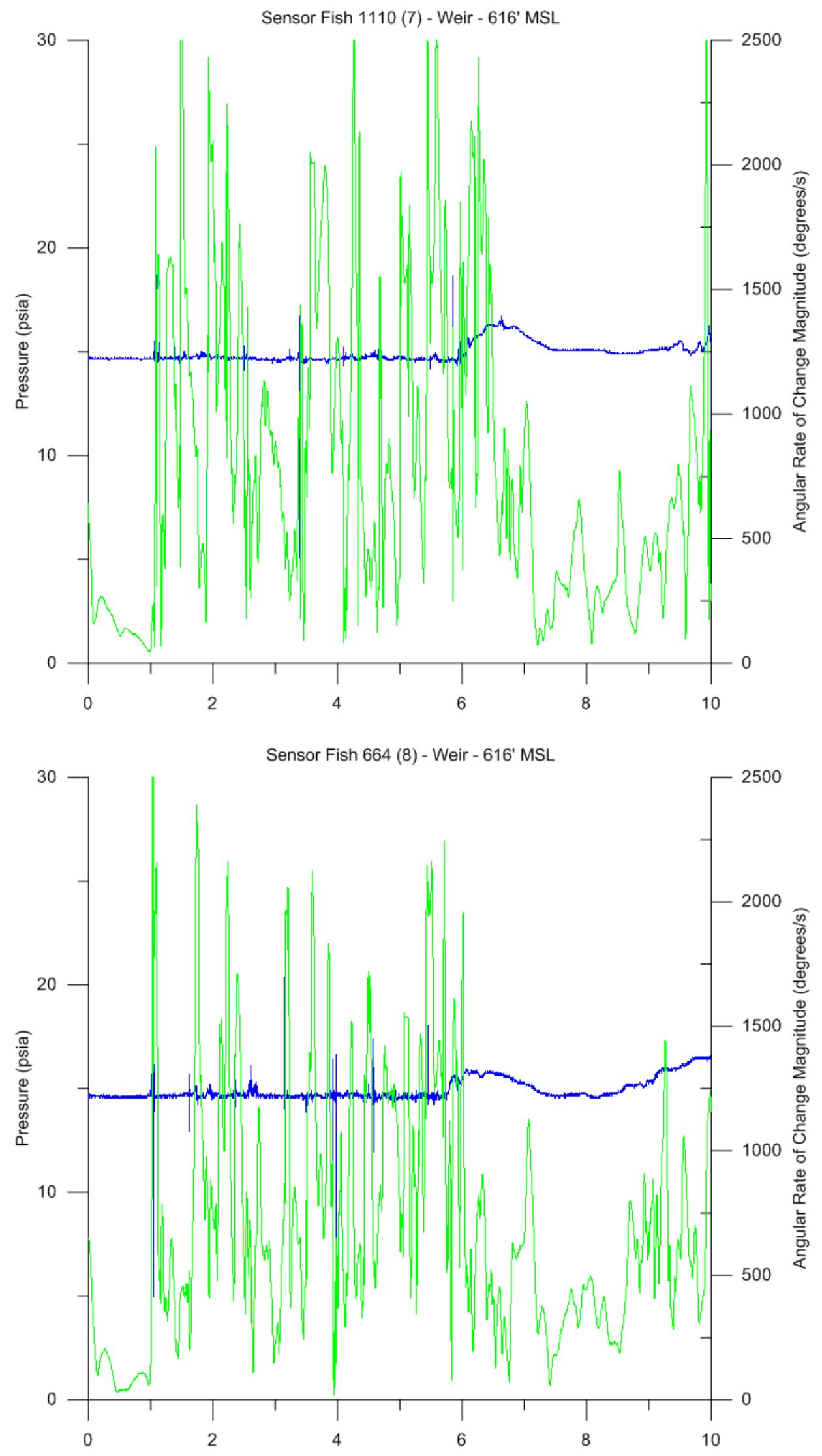

D. 6 

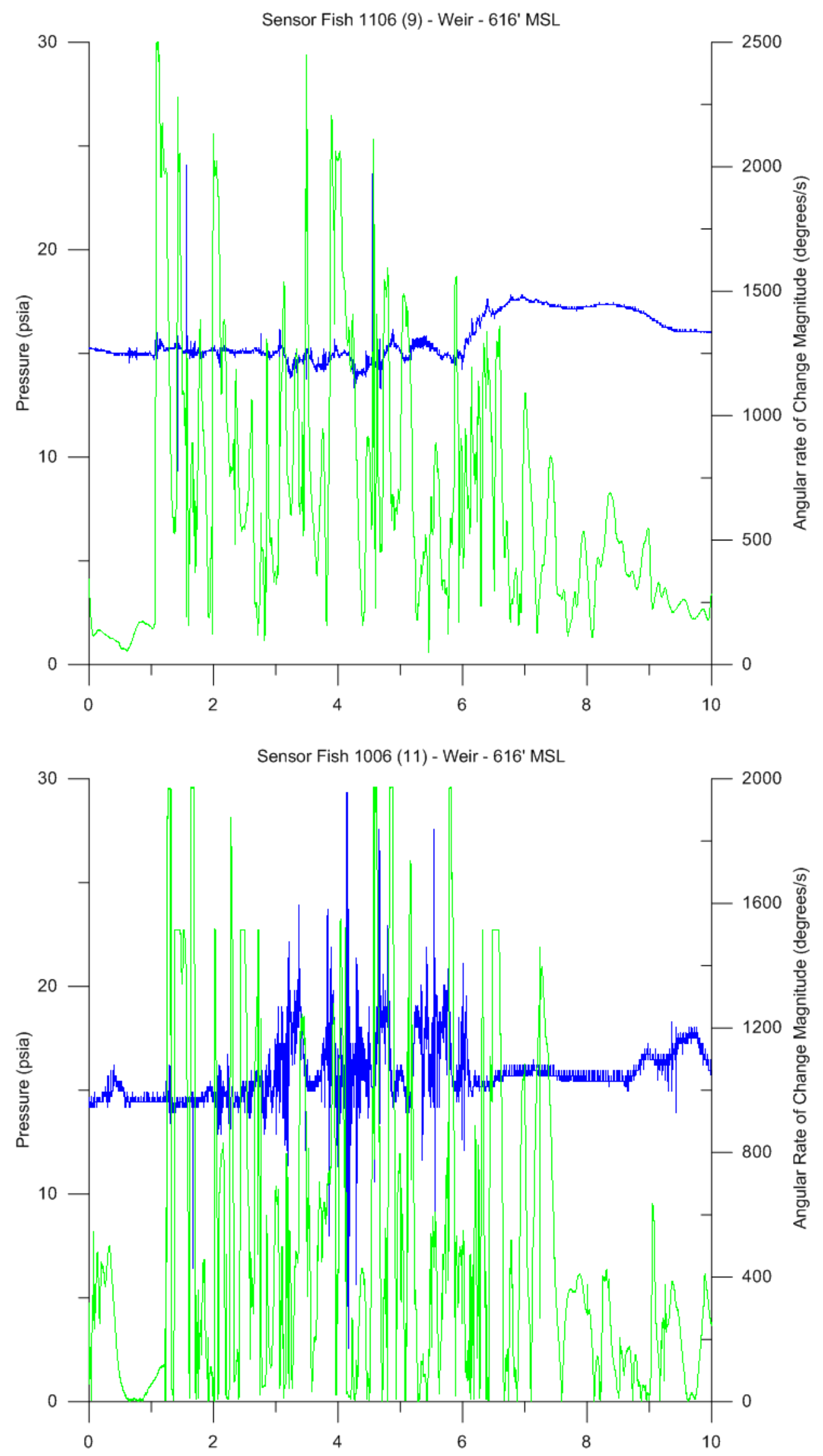

D. 7 

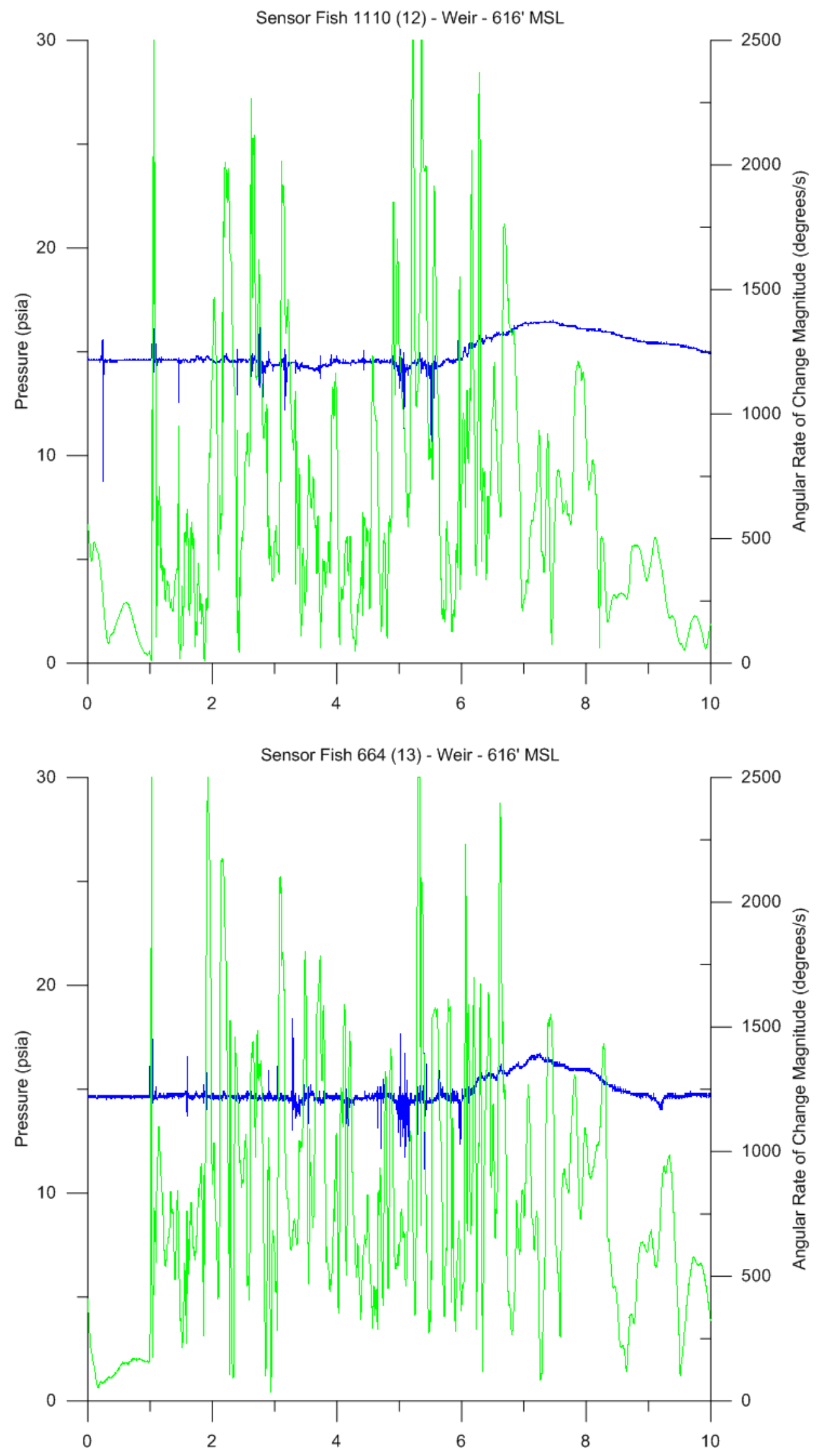

D. 8 

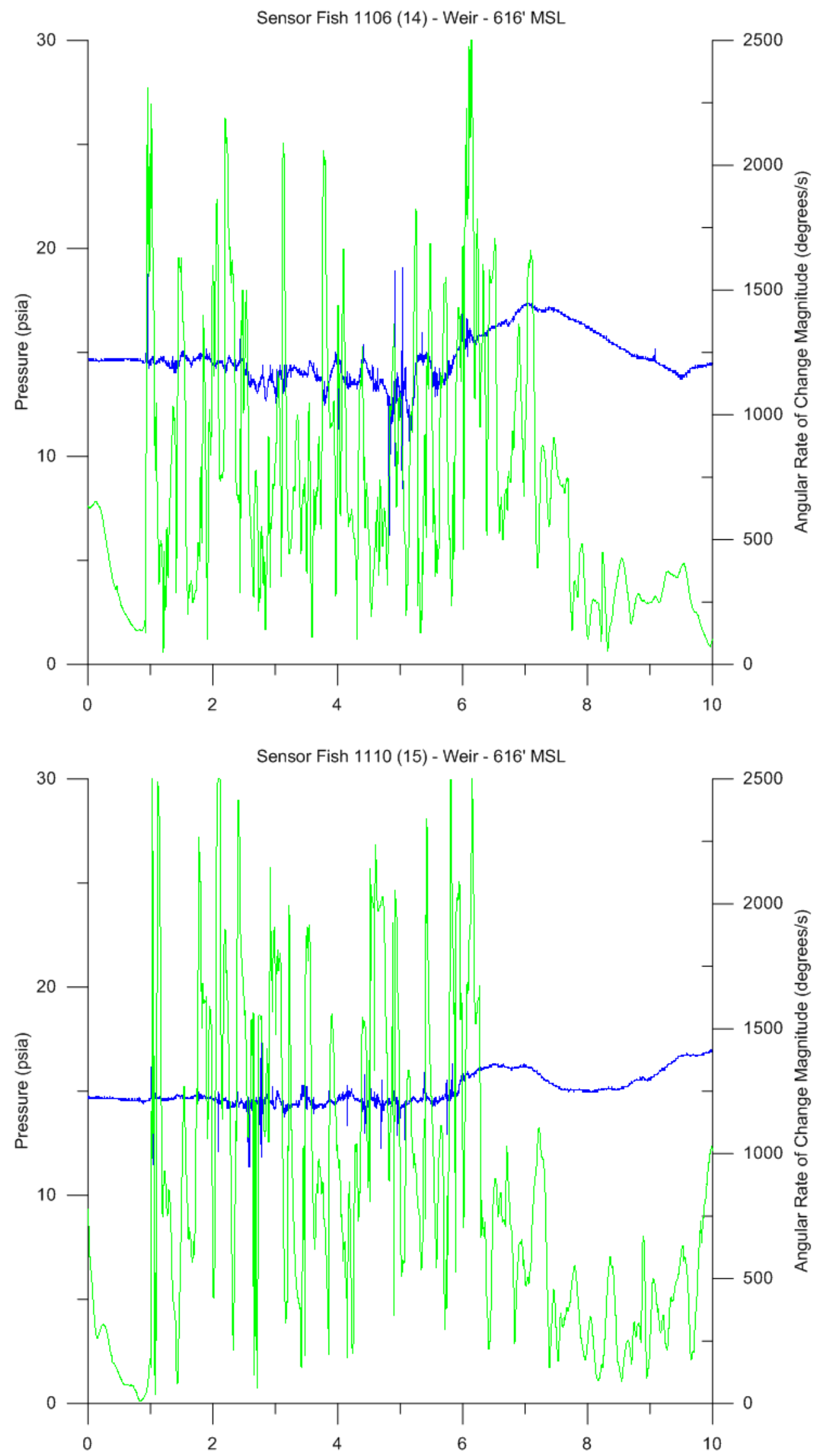

D.9 



D.10 
Sensor Fish Weir Passage Low-Forebay Elevation (616 ft MSL)

Adult Pipe 

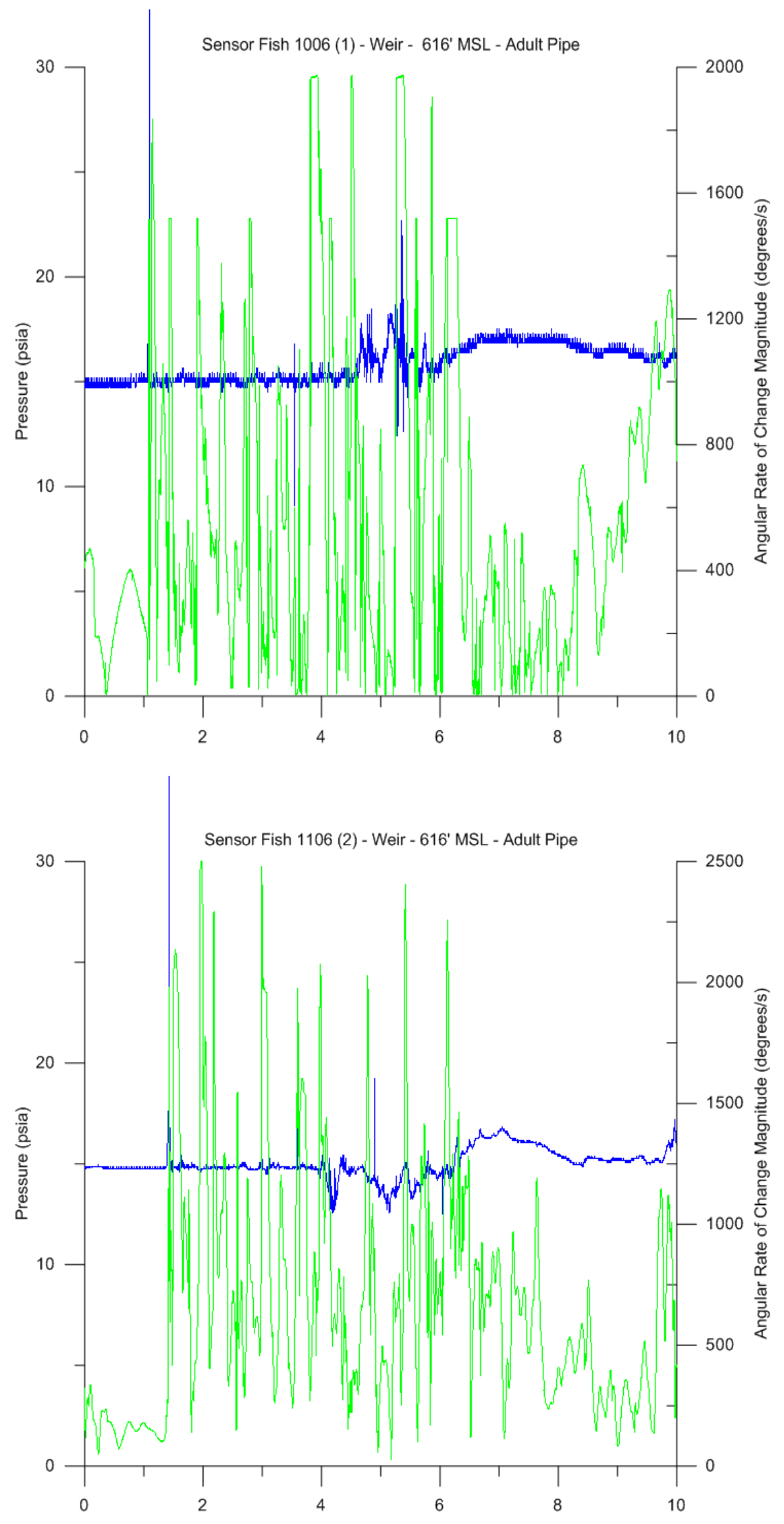

D.13 
Sensor Fish Weir Passage High-Forebay Elevation (634 ft MSL) Juvenile Pipe 

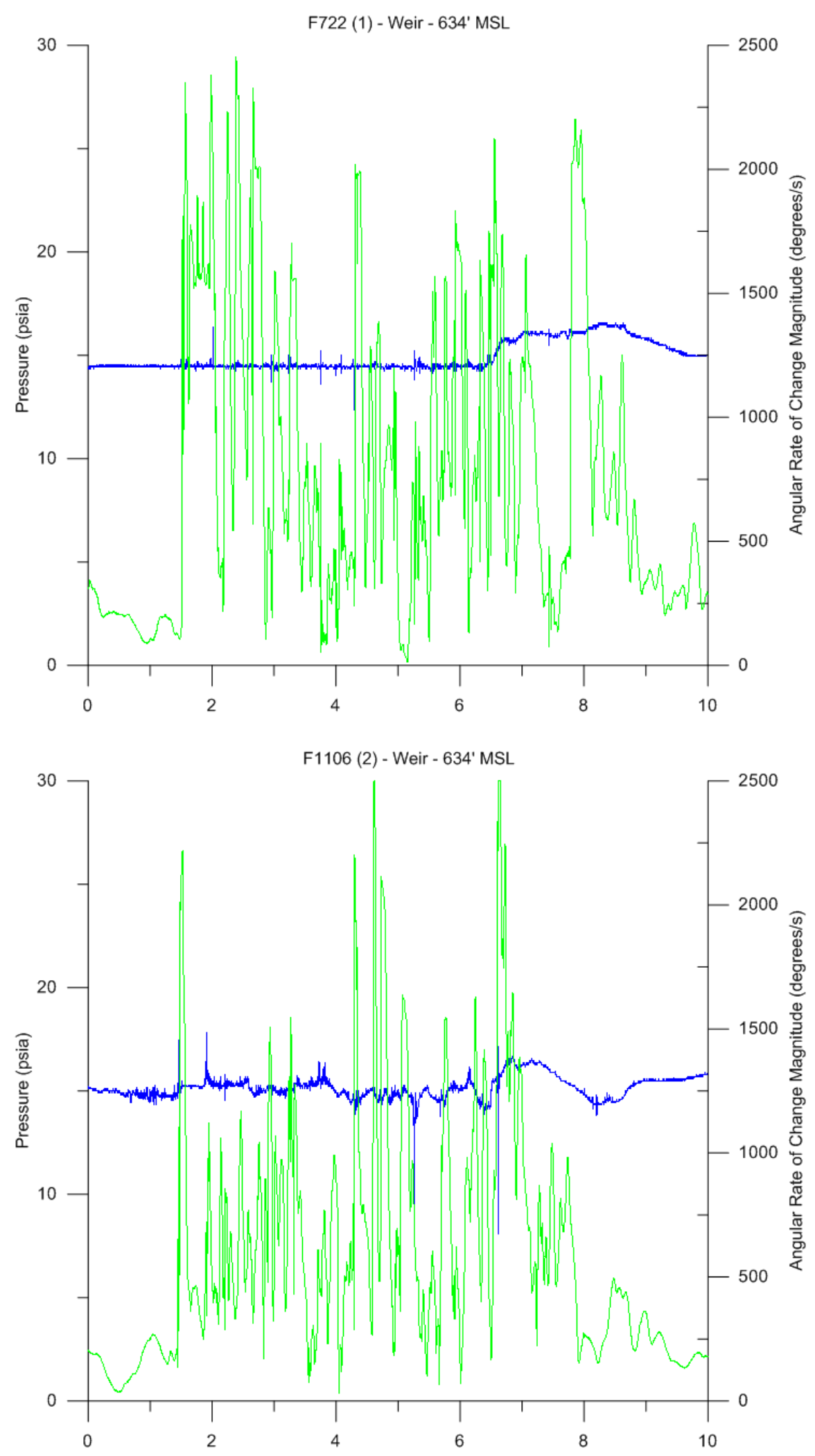

D.17 

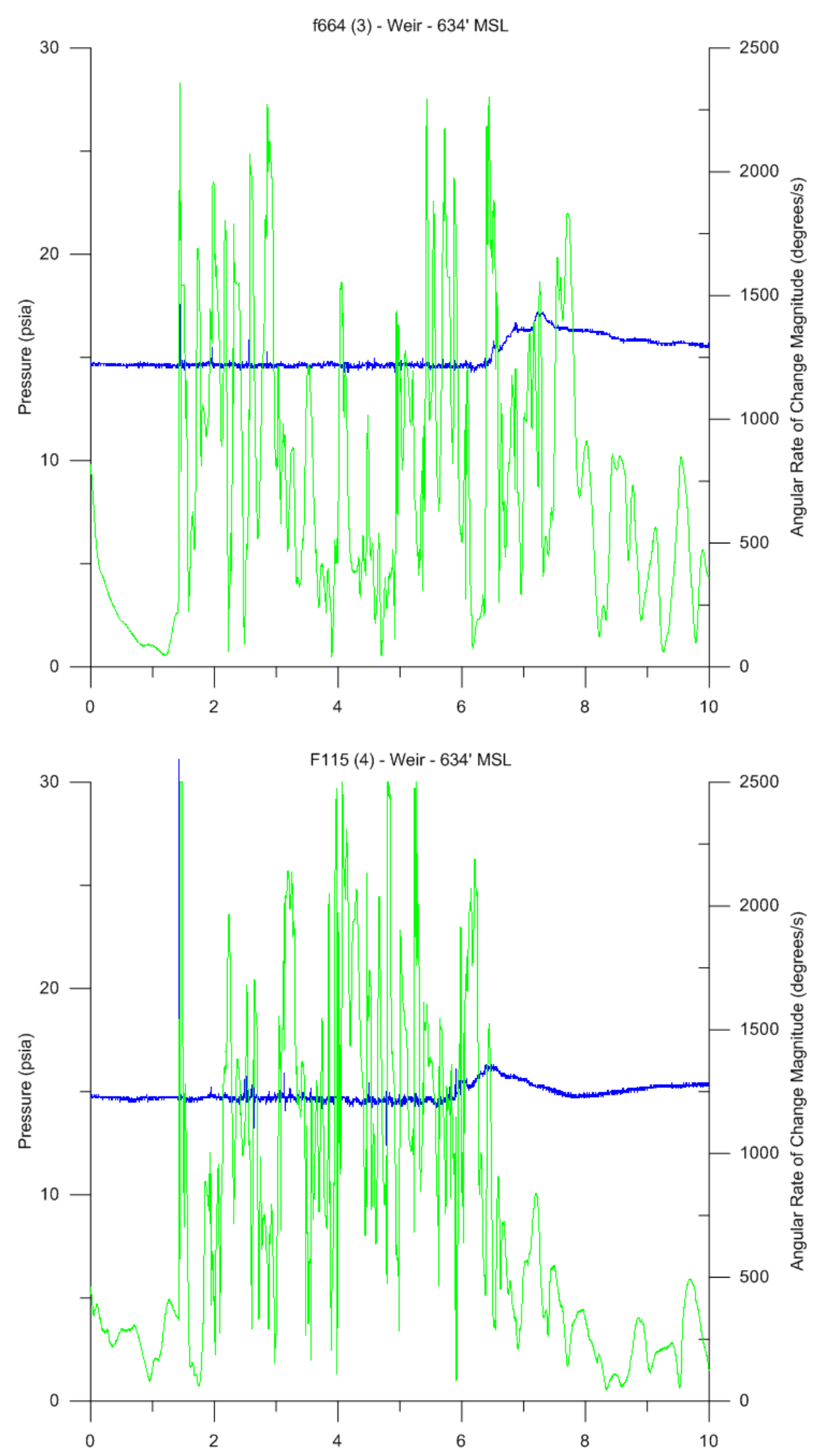

D.18 

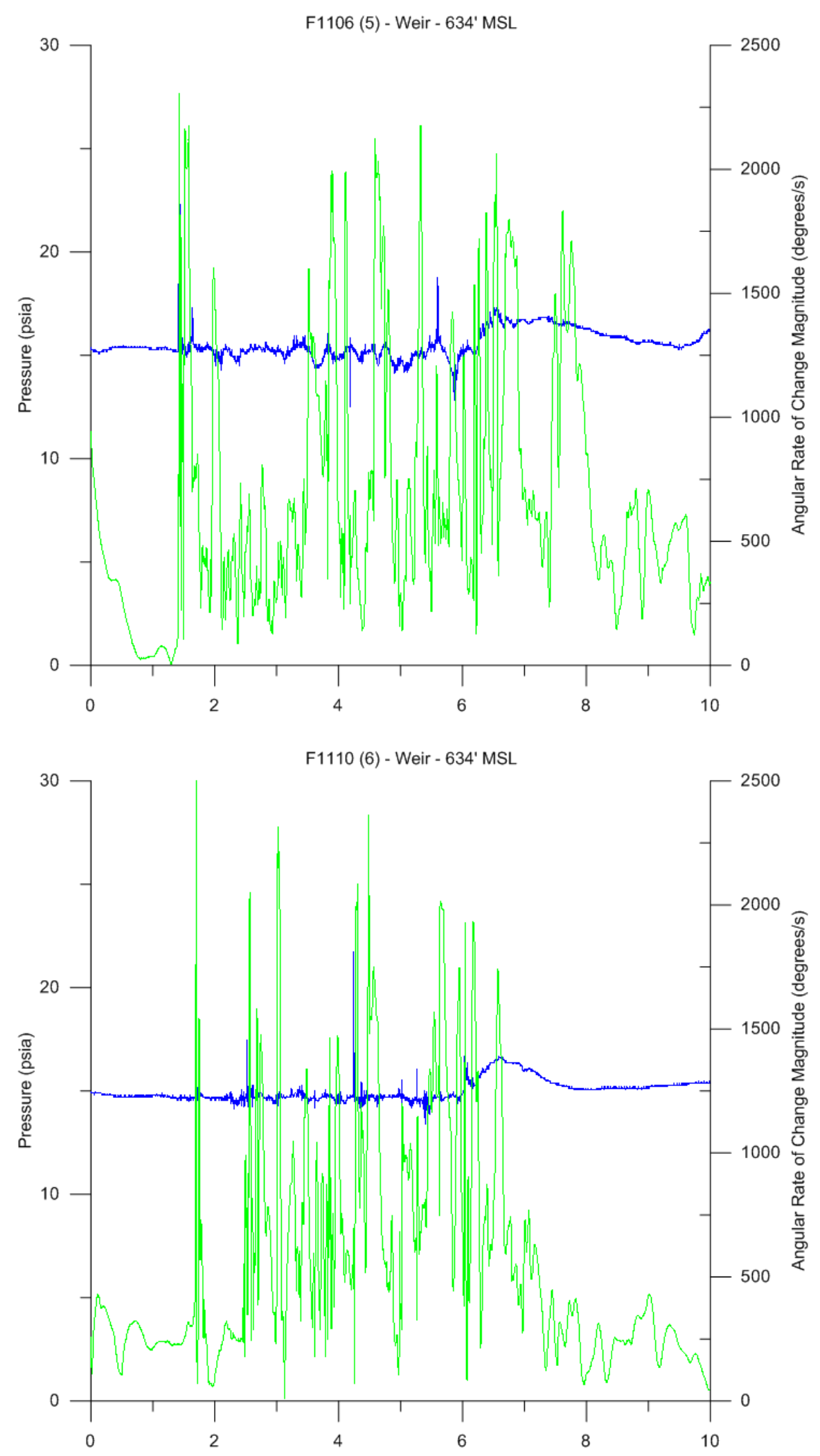

D.19 

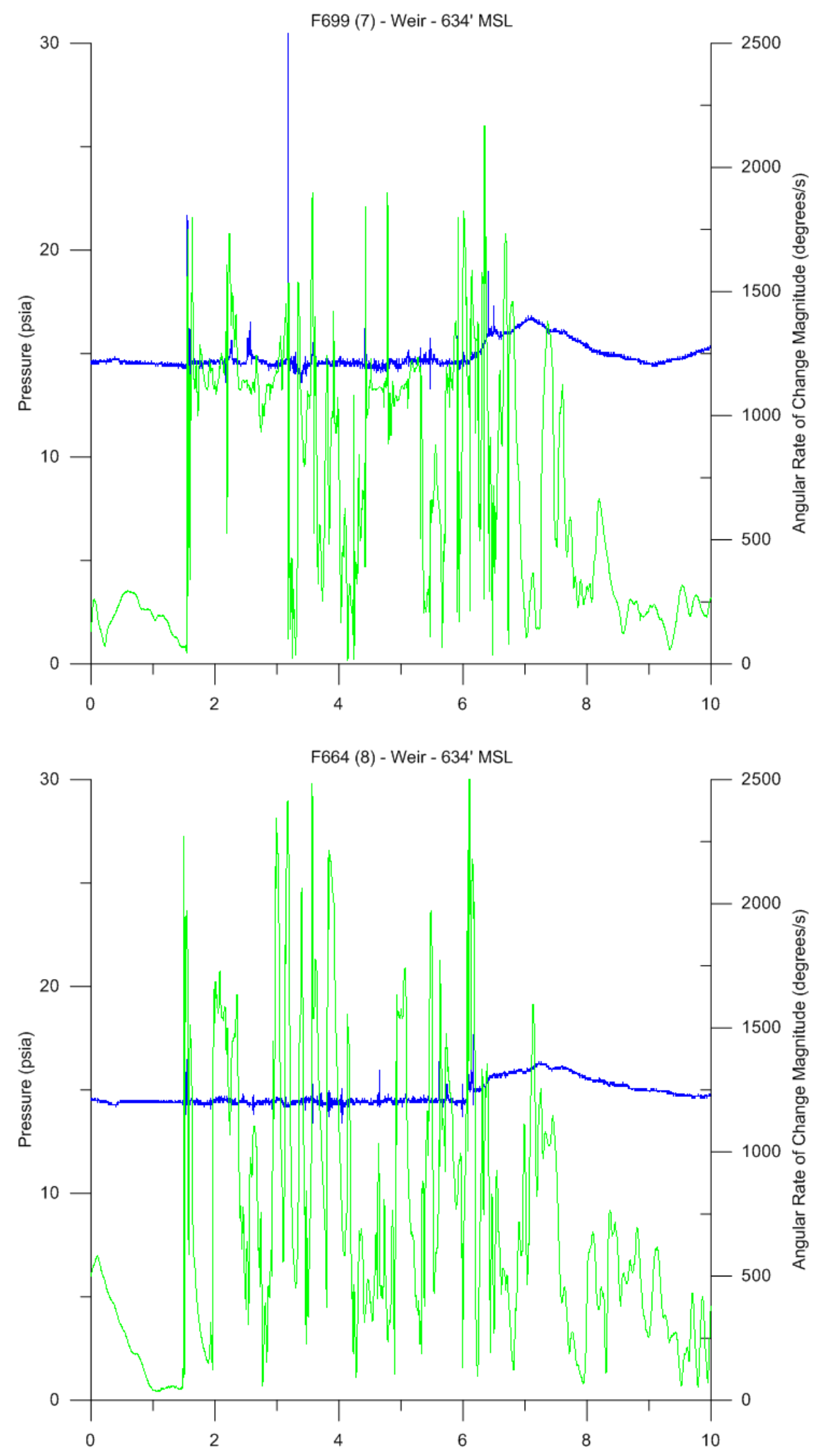




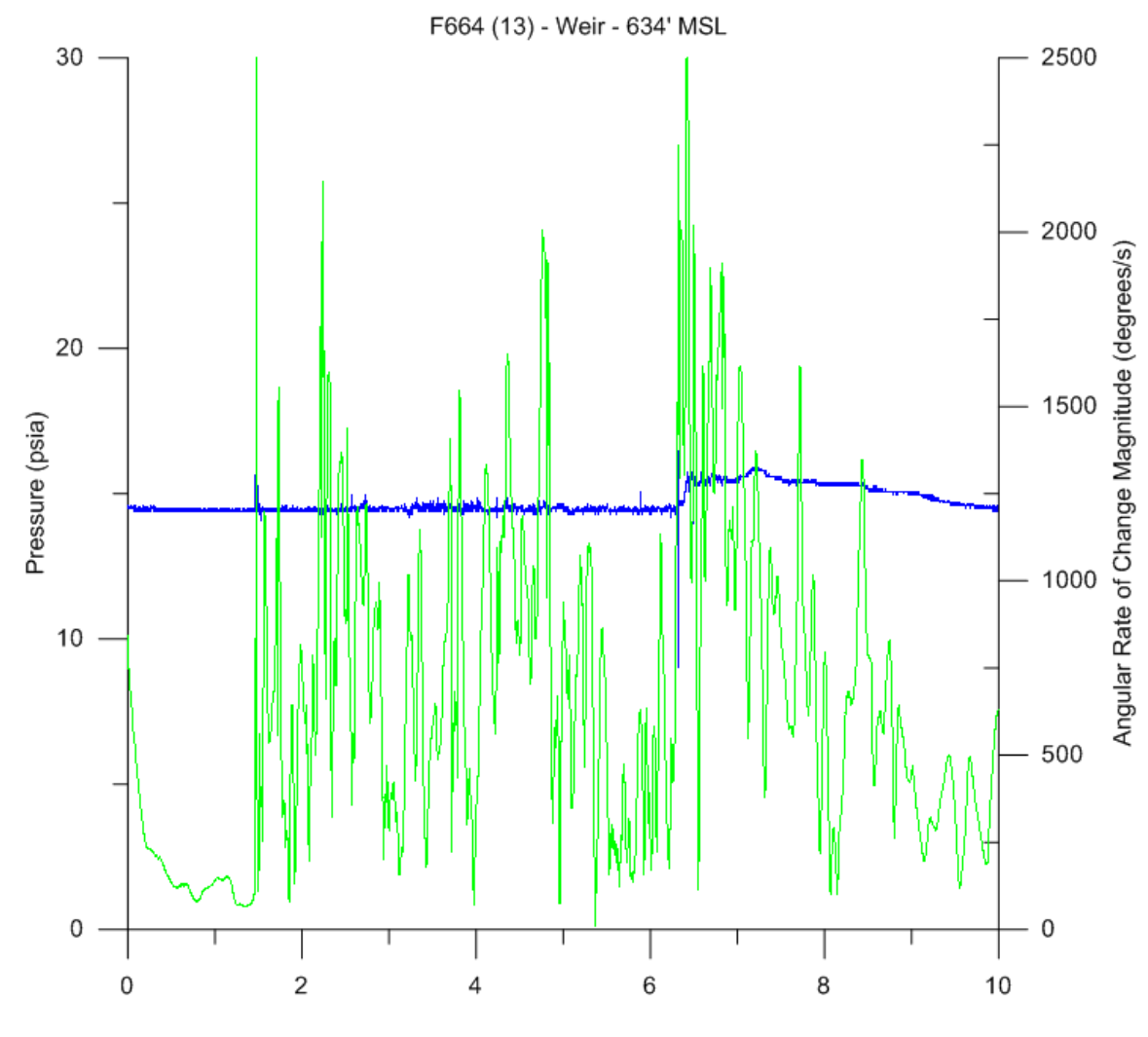

F699 (14) - Weir - 634' MSL

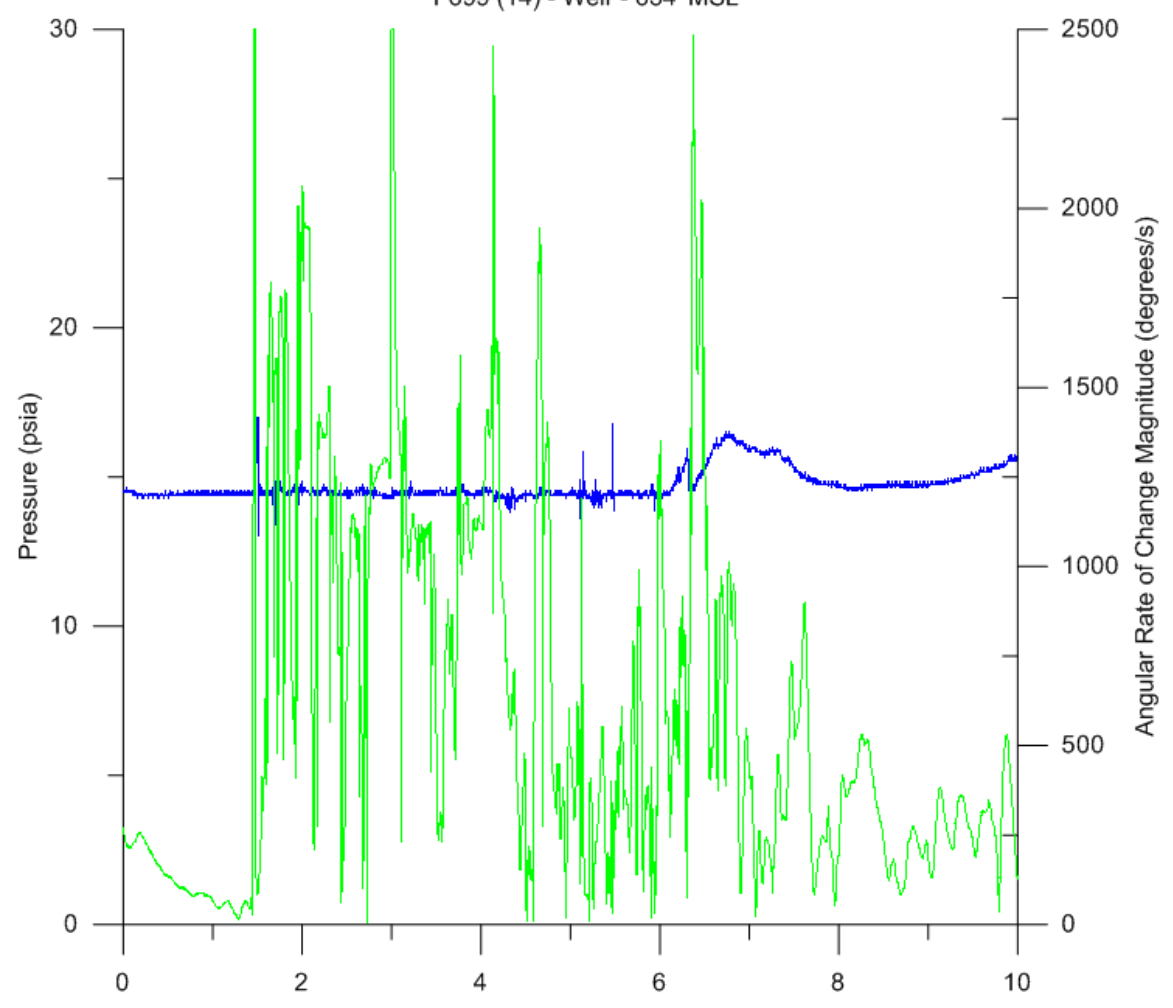



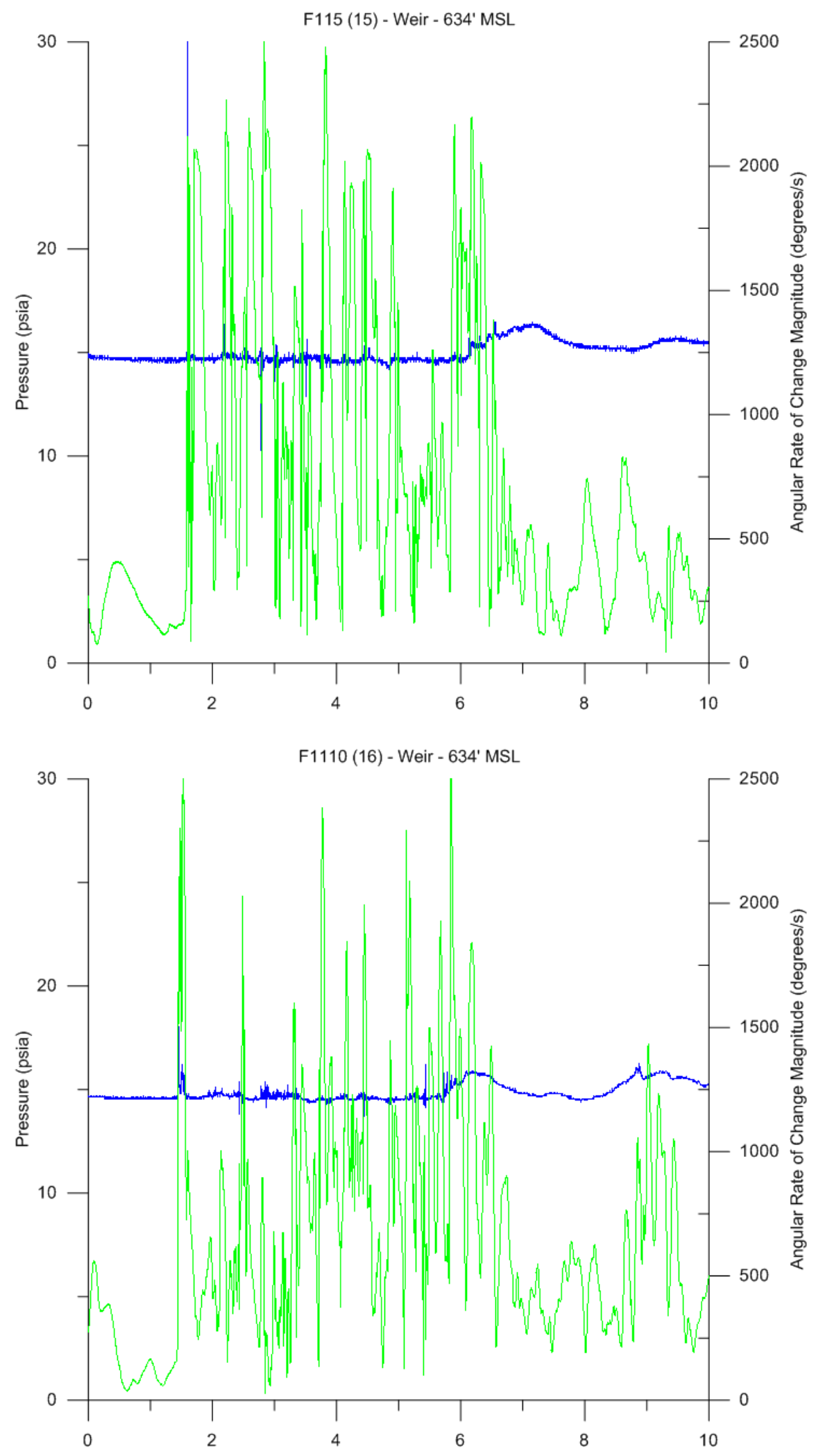


Sensor Fish Weir Passage High-Forebay Elevation (634 ft MSL)

Adult Pipe 

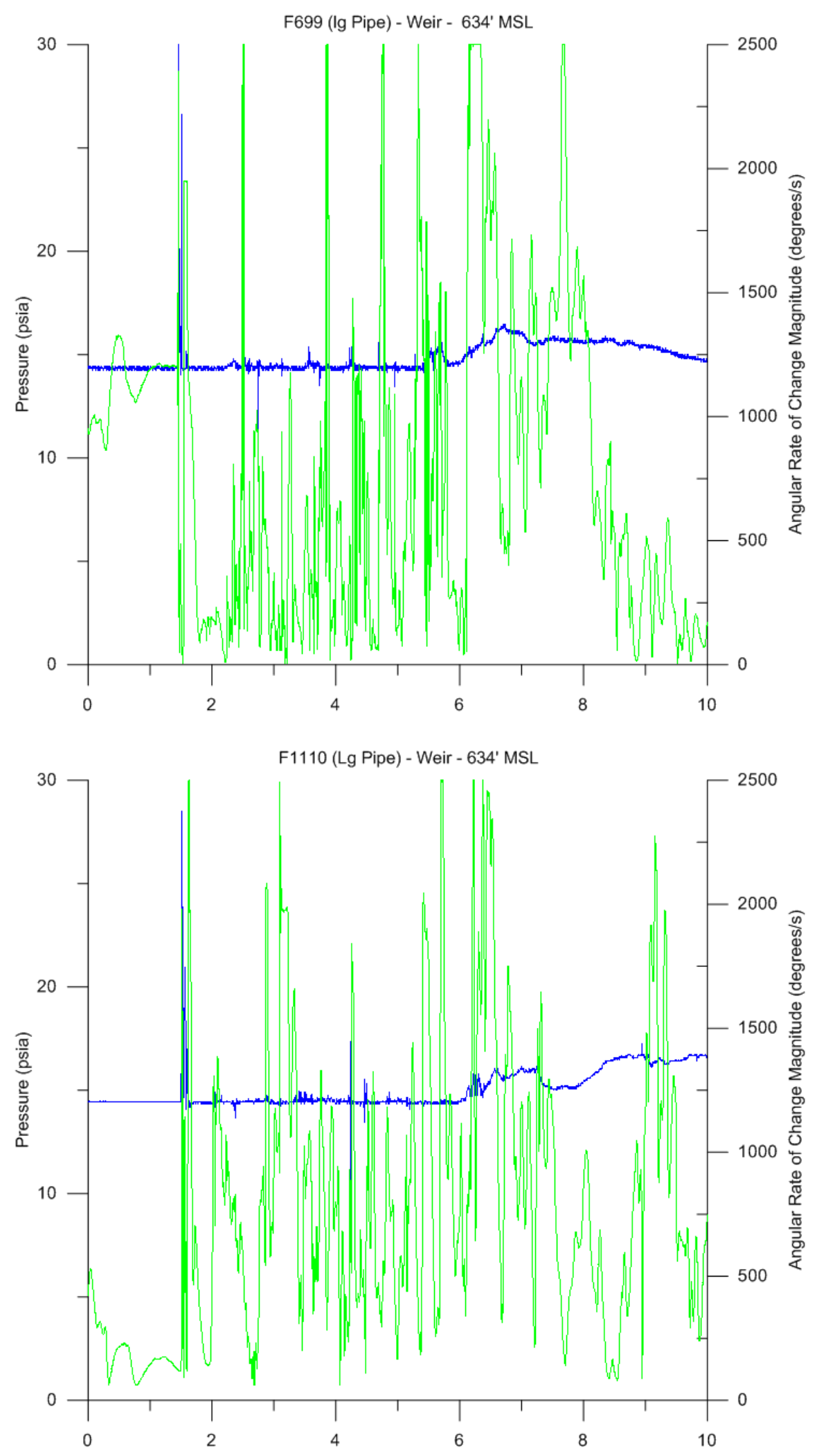


\section{Sensor Fish Turbine Passage - Low-Forebay Elevation (616 ft MSL) 2.8/3.0 MW}



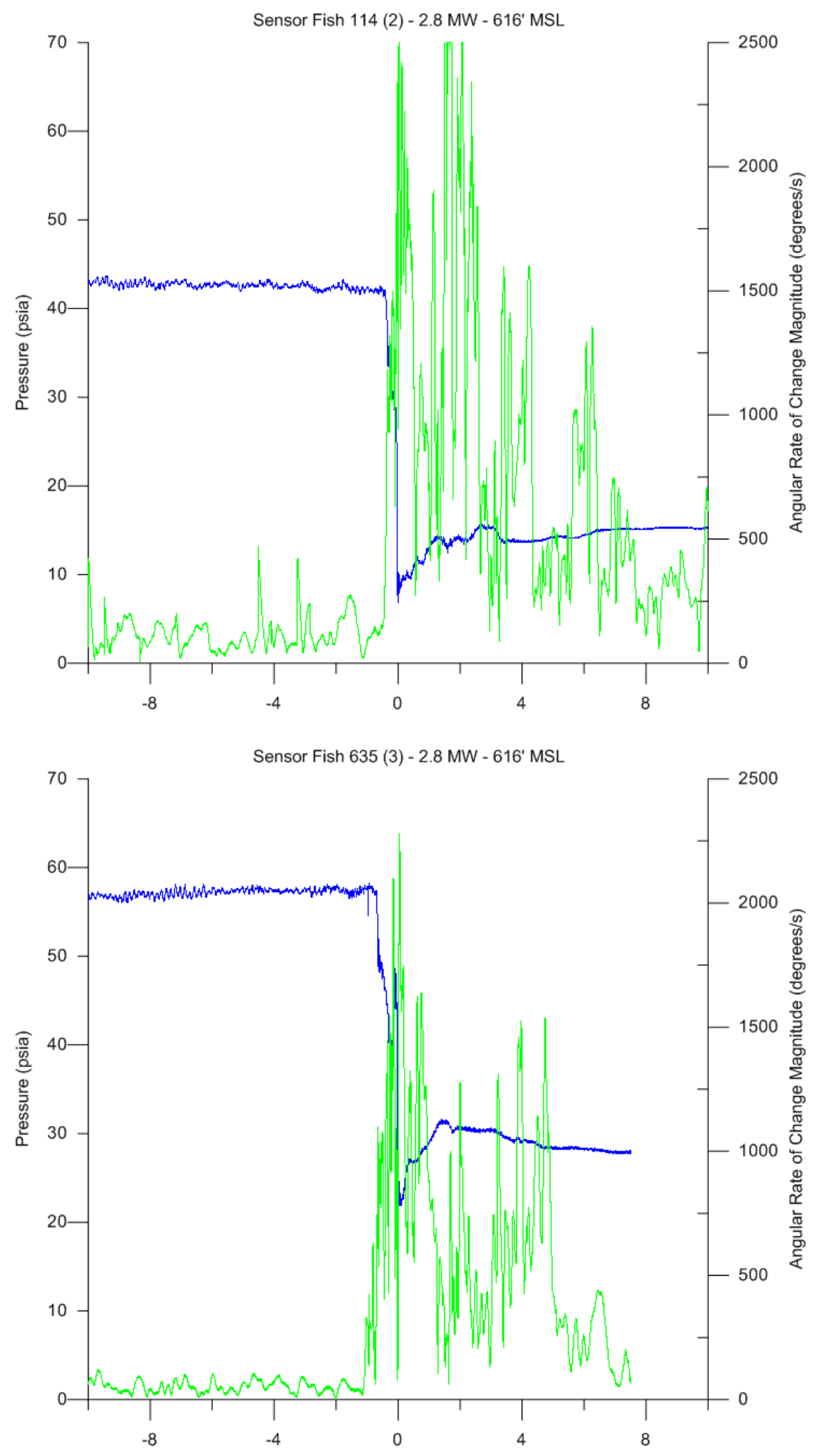

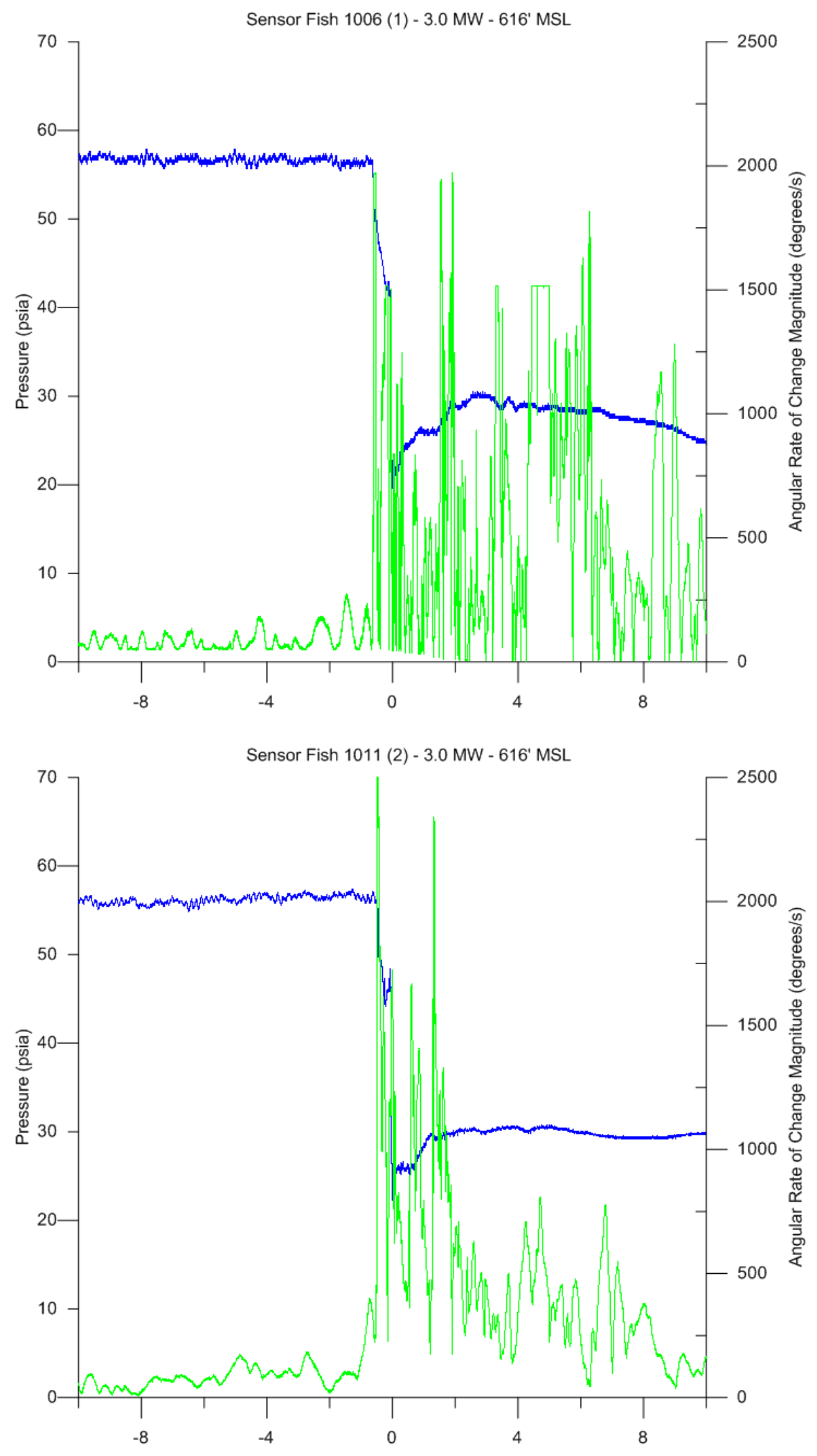

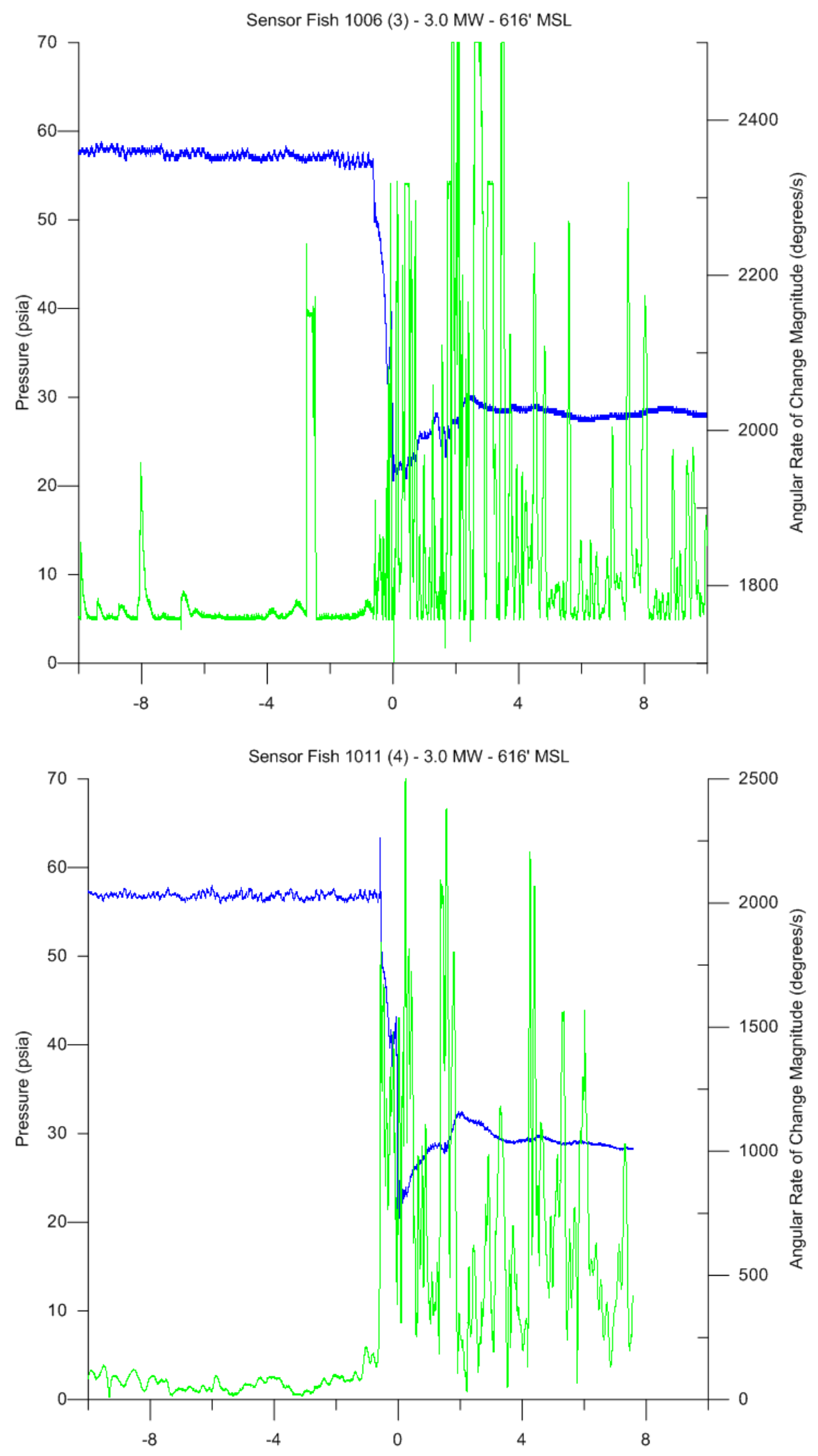


\section{Sensor Fish Turbine Passage - Low-Forebay Elevation (616 ft MSL) \\ 4.9/5.0 MW}



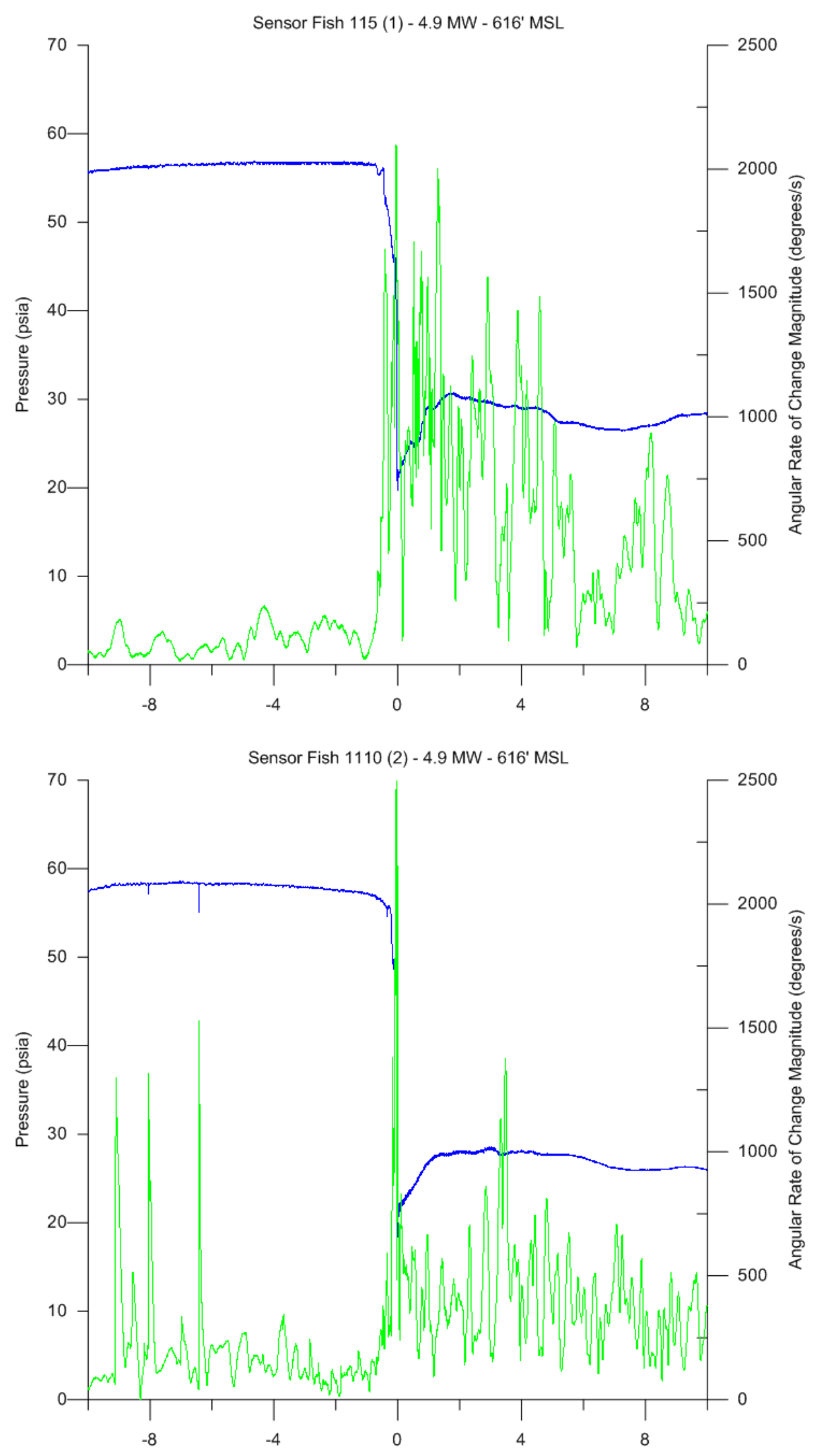

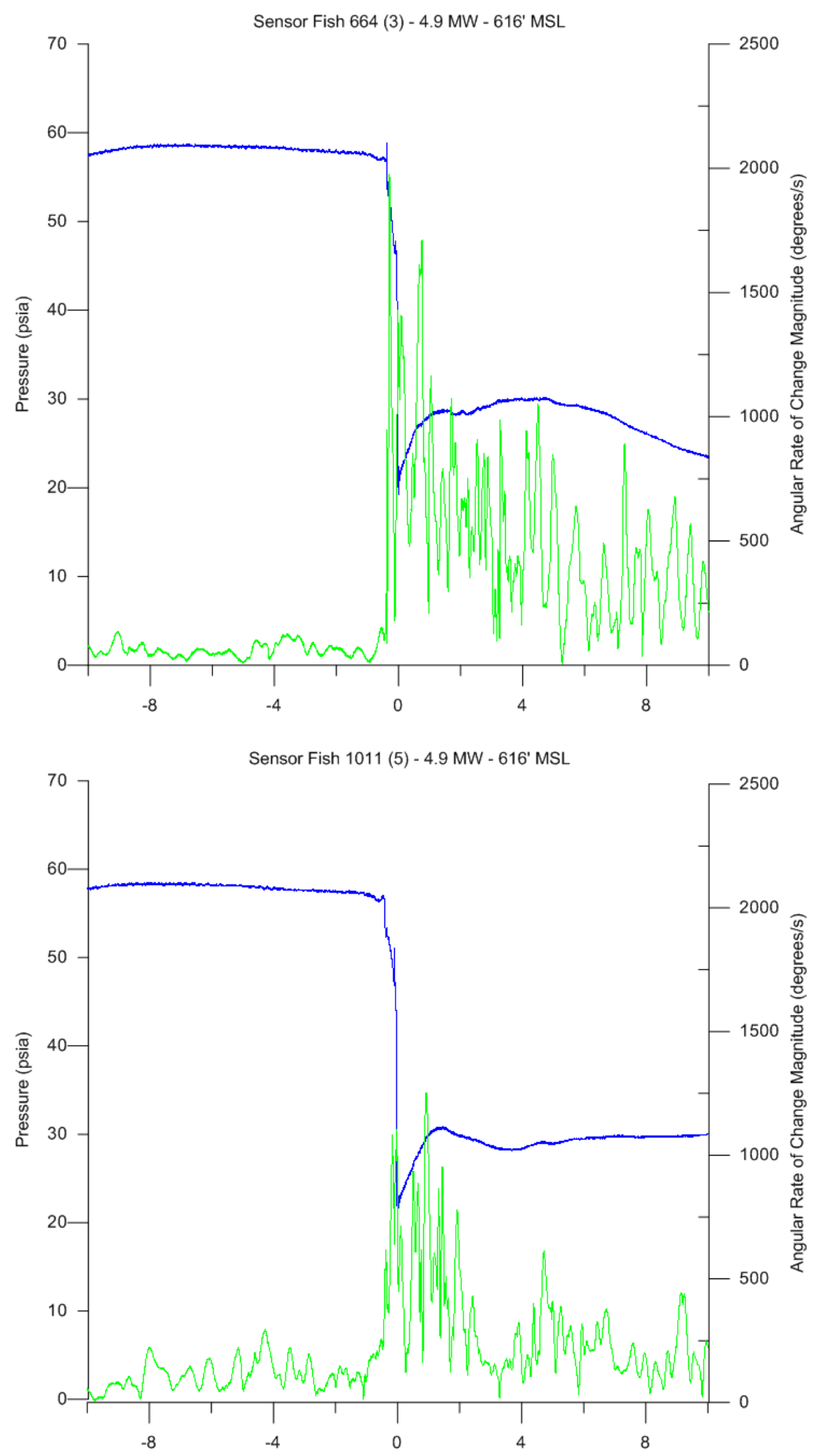






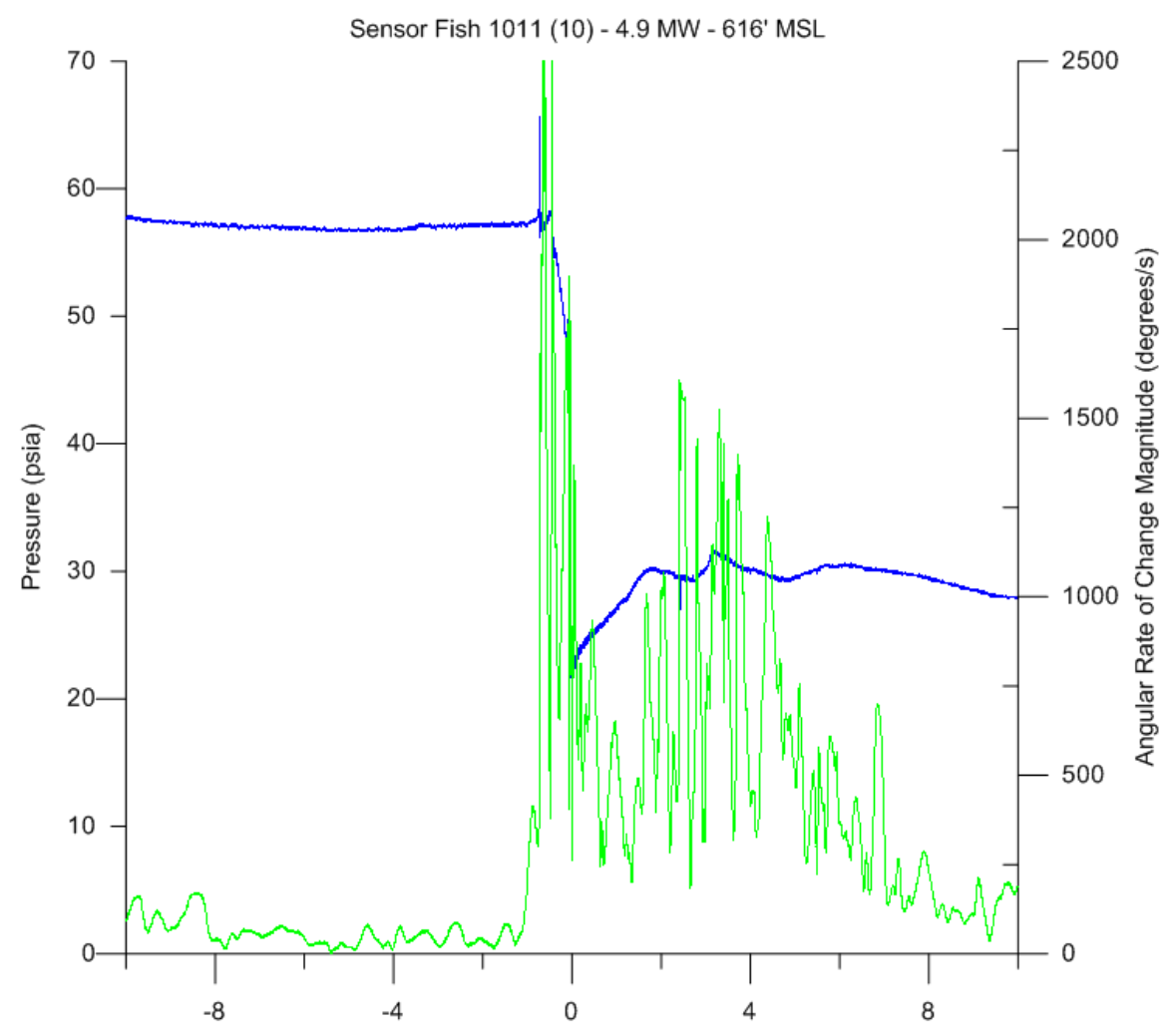




\section{Sensor Fish Turbine Passage - Low-Forebay Elevation (616 ft MSL) 6.0 MW}



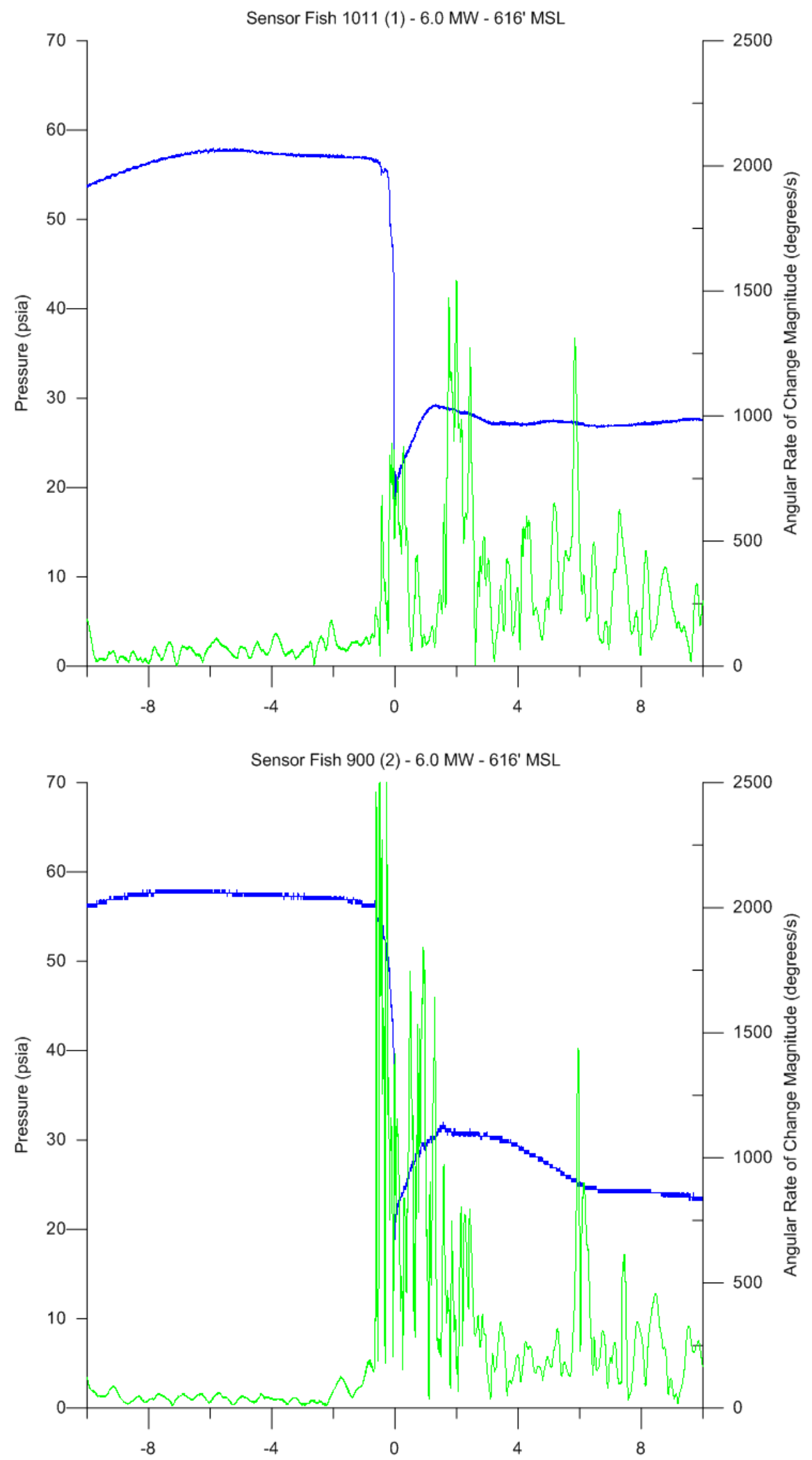

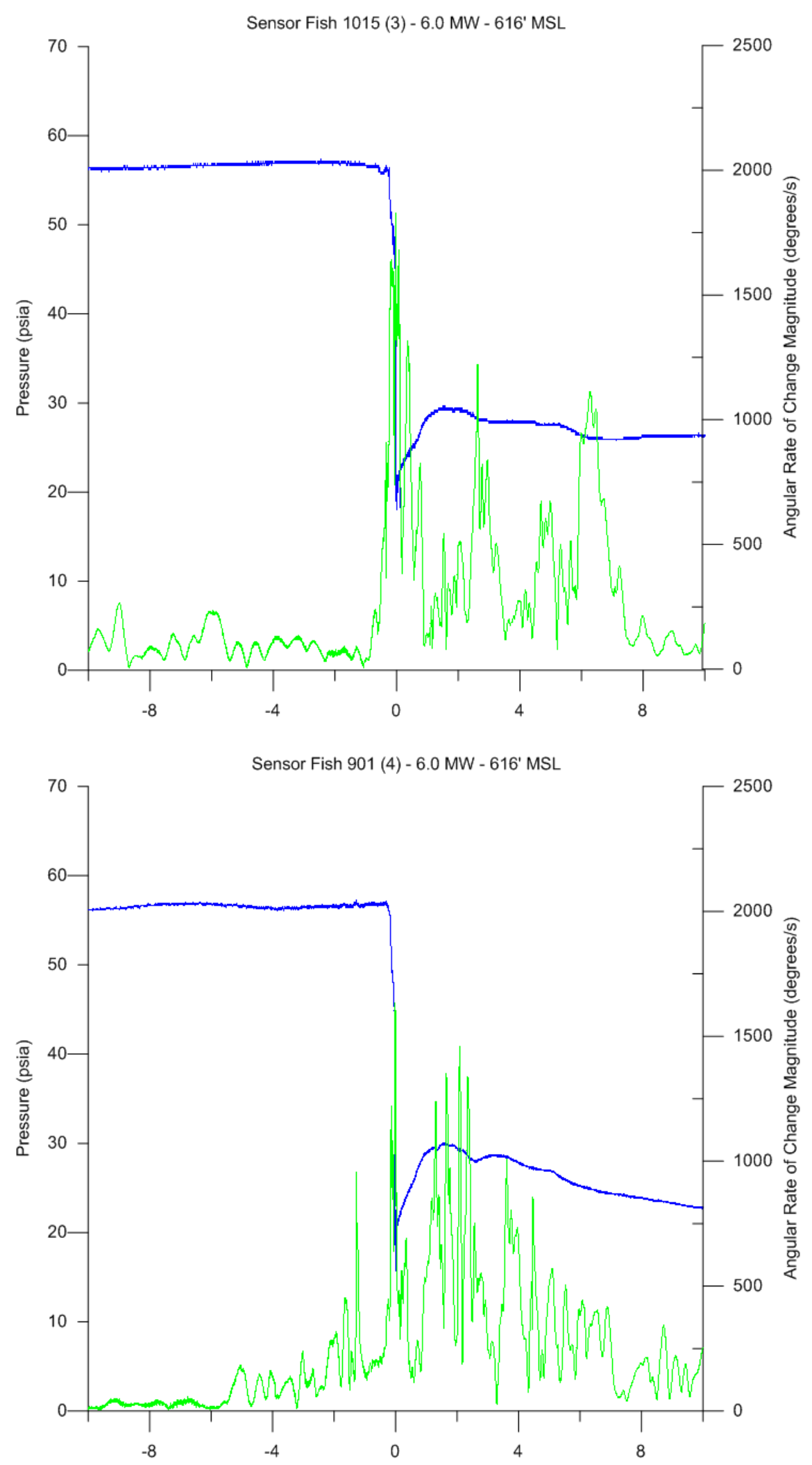

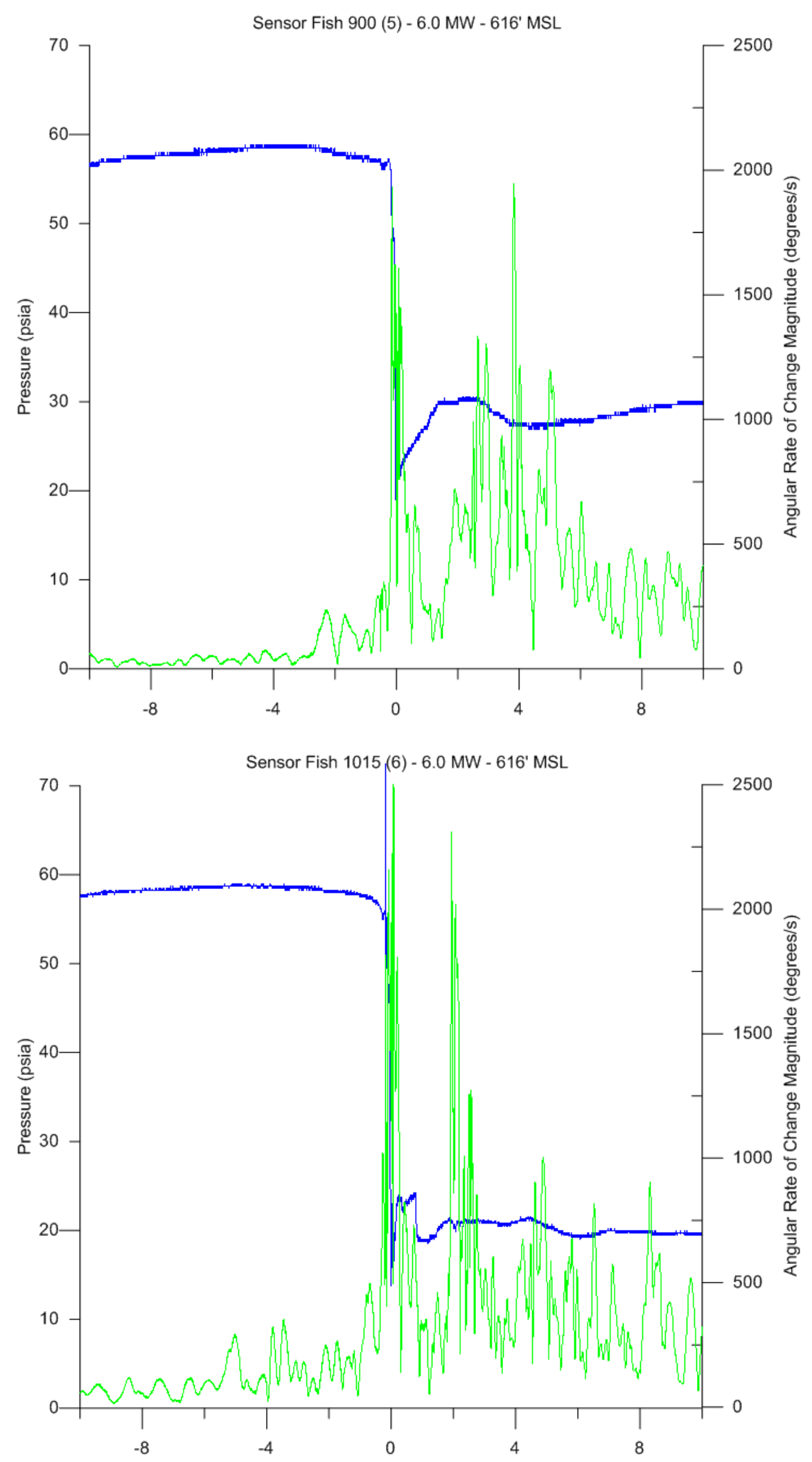
Sensor Fish Turbine Passage -

Low-Forebay Elevation (616 ft MSL)

7.0 MW 






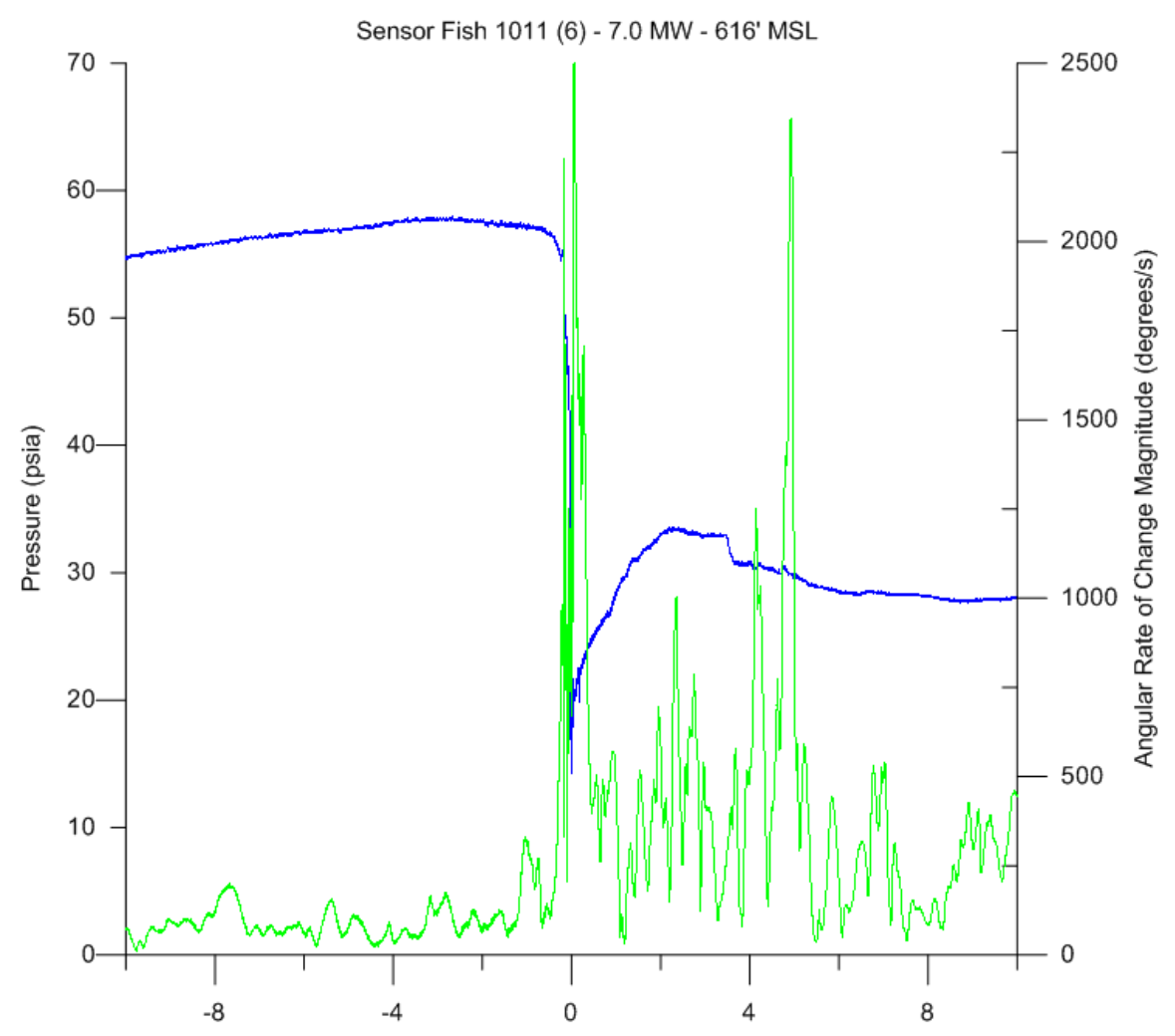

D.53 
Sensor Fish Turbine Passage High-Forebay Elevation (634 ft MSL)

4.9/5.0 MW 

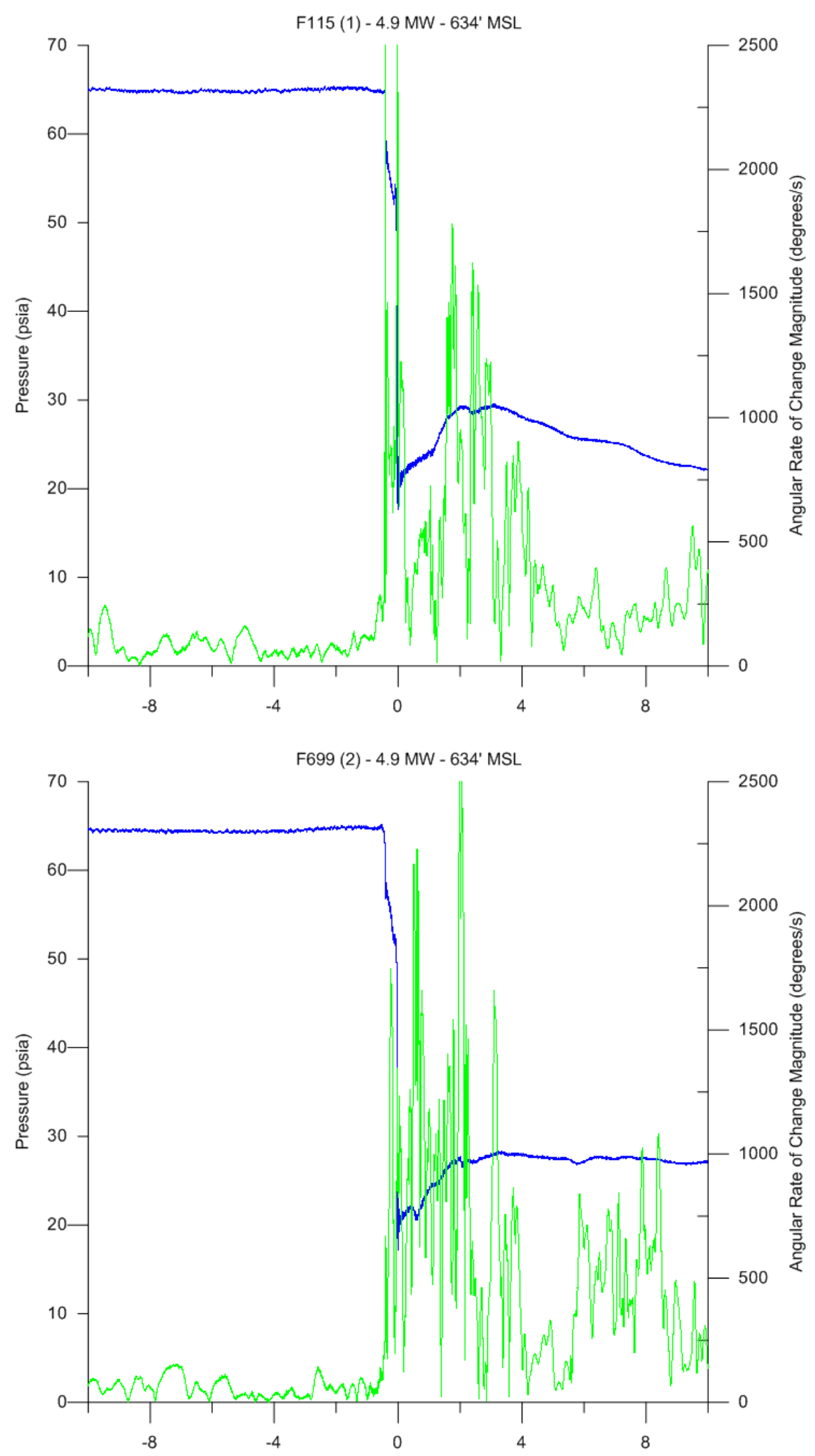
Sensor Fish Turbine Passage High-Forebay Elevation (634 ft MSL) 6.5 MW 


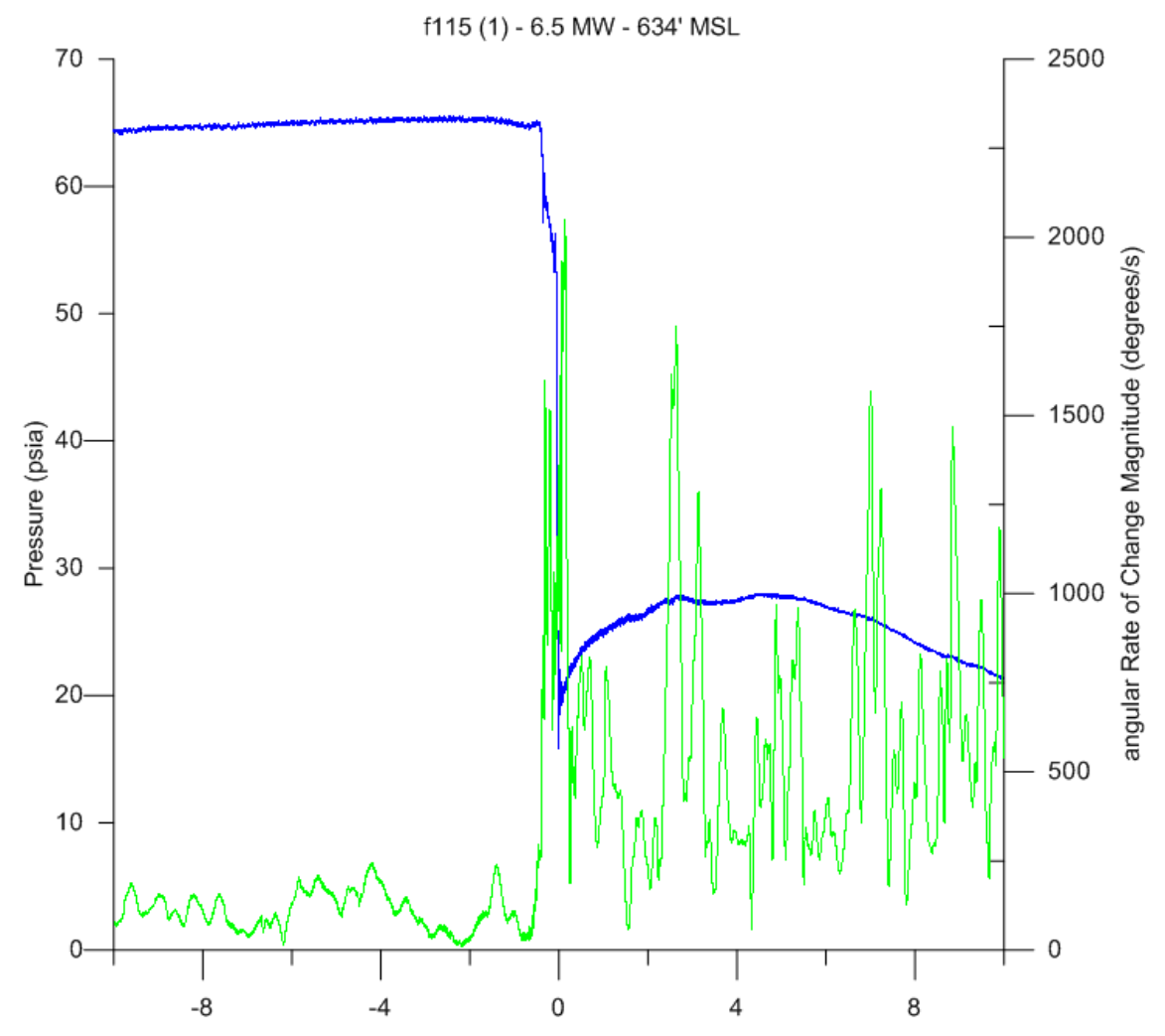

D.61 
Sensor Fish Turbine Passage High-Forebay Elevation (634 ft MSL) $9.0 \mathrm{MW}$ 

